\title{
A questão do desejo da gravidez e da maternidade em mulheres vivendo com HIV/Aids, na perspectiva Psicanalítica
}

\author{
Karina Franco Zihlmann
}

Dissertação apresentada ao Programa de Pósgraduação em Saúde Pública para obtenção do título de Mestre em Saúde Pública.

Área de Concentração: Saúde Materno-Infantil Orientadora: Prof ${ }^{a}$ Dra Augusta Thereza de Alvarenga

São Paulo

2005

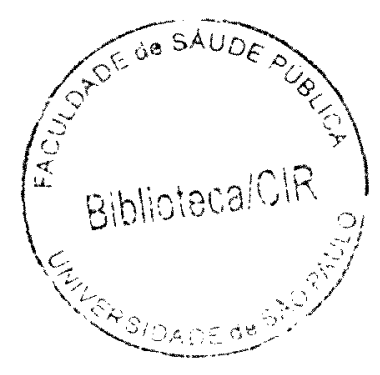




$$
45023 / 2005 \text { dic }
$$

Autorizo, exclusivamente para fins acadêmicos e científicos, a reprodução total ou parcial desta dissertação, por processos fotocopiadores. Ao usá-lo, cite a fonte.

Data:

Assinatura: 
Banca Examinadora 


\section{Dedicatória}

Dedico este trabalho ao grande amor de minha vida: meu filho, Khaled, que tem me ensinado, em seus 20 meses de vida, a me tornar uma pessoa melhor. Sou também grata a esse "rapazinho", que trouxe alegria e esperança para minha vida, permitindo que eu voltasse a acreditar na inocência e na beleza do ser humano. 


\section{Agradecimentos}

Agradeço a todos aqueles que contribuíram ou permitiram com que este trabalho pudesse deixar de ser uma idéia e se tornasse uma realização.

Ao CNPq, pelo suporte financeiro.

Agradeço à minha orientadora, amiga e mestra, Prof ${ }^{2}$ Augusta Thereza de Alvarenga. Graças à sua ousadia e determinação, este trabalho foi acolhido, gestado e concretizado. Mas não foi só isso: sou grata, sobretudo, pelo acolhimento pessoal, generoso e desinteressado. É admirável que pessoas como você existam e permitam que a gente esteja por perto. Tem sido um privilégio ser sua aluna e, a cada dia, poder fazer valer a admiração que sua convivência inspira.

Aos meus pais, que aceitaram me resgatar. Obrigada pelo apoio, que surgiu na hora em que mais precisei. Aos meus irmãos, Rico e José Luiz, que sempre acreditaram no meu trabalho e que fizeram um esforço especial em me "aturar" todo esse tempo.

Ao meu companheiro, Dr Jorge Casseb, que suporta minhas idiossincrasias e não esconde as próprias. Obrigada pelo apoio, pela sinceridade e por ser meu cúmplice no bem sucedido projeto chamado Khaled. Com amor, obrigada.

Agradeço à Avaids e ao Instituto de Infectologia Emílio Ribas, pela possibilidade da realização desta pesquisa nas respectivas instituições.

À Dra. Carla Vasquez, pela acolhida do trabalho, além do suporte intelectual e institucional para a realização desta pesquisa. Compartilhamos, intrigadas, as mesmas questões sobre o assunto estudado e decidimos ousar, investigando o tema com a abertura que a interdisciplinaridade permite.

Ao Prof Alberto Olavo Advíncula Reis, pelas preciosas e generosas contribuições, tanto no exame de projeto (qualificação), quanto na pré-banca, para realização deste trabalho.

À Prof Wilza Vilela, pelas contribuições valiosas, por ocasião do exame de projeto.

Aos Professores José Ricardo Ayres, Vera Paiva, Ivan França Jr, pela possibilidade de aprender mais sobre temas, que permitiram a ampliação de meus conhecimentos nas disciplinas cursadas.

Ao Prof ${ }^{\circ}$ Luiz Carlos Nogueira (in memoriam), por ter aprendido que um mestre tem competência, seriedade e postura. Aprendi, além disso, que, para brilhar, devemos ter dignidade, e que uma palavra de apoio e cuidado, na hora certa, pode mudar o mundo. Seu brilho sempre estará presente em minha vida. 
À Prof Helena Bicalho, que soube me ajudar a construir respostas para questões cruciais deste trabalho, no que concerne à perspectiva psicanalítica. Sou especialmente grata por este encontro afortunado e raro.

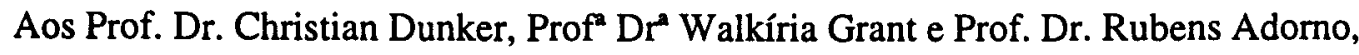
pela disponibilidade em colaborar com este trabalho.

Ao Prof ${ }^{\circ}$ Dr. Gil Bernard, pela contribuição na revisão do resumo em inglês.

Aos funcionários e amigos de Departamento de Alergia e Imunologia do LIM 56 e do ambulatório ADE 302 do HC FMUSP.

Aos amigos e funcionários do Fórum Lacaniano da Sessão São Paulo.

Aos amigos da disciplina de "Fundamentos da Investigação Científica" e da disciplina "O campo Lacaniano: desejo e gozo".

Aos amigos: Denise Argolo Estill, Maria Melo, Ana Carolina Pereira Ferreira, Patrícia Mara, Cláudia Abreu, Marli Bastos, Patrícia Gonçalves Dias, Sálvio Franco, Niraldo Oliveira Santos, Celeste Gobi, Marlene Inácio e Helena Lima. Todos Psicólogos. Todos gente "do bem", para os quais manifesto minha gratidão e amizade sincera. Por ter vocês em minha vida, sou privilegiada.

Agradeço à Carminha, pelo apoio e estímulo, sempre evidente e disponível.

Aos funcionários do Departamento de Saúde Materno-infantil da FSP: Iara, Leandro e Maria, pela disponibilidade e apoio. À Fumica, pela correção de português.

À D. Alice Silva, minha funcionária pessoal, por ter cuidado do meu bem mais precioso (meu filho), enquanto eu escrevia boa parte deste trabalho.

$\mathrm{E}$, finalmente, agradeço, em especial, às 15 mulheres entrevistadas que, generosamente, dispuseram-se a falar de si, respondendo sinceramente a questões, muitas vezes, difíceis. Elas me ensinaram, com sua emoção, que a maternidade é muito mais que uma escolha racional: é a abertura para uma mudança radical e corajosa de vida. Com profundo respeito, dedico a vocês o "amor da absoluta diferença", como diria Lacan. 
ZIHLMANN, Karina Franco. A questão do desejo da gravidez e da maternidade em mulheres vivendo com HIV/Aids na perspectiva Psicanalítica. São Paulo; 2005. [Dissertação de Mestrado - Faculdade de Saúde Pública da USP].

\section{Resumo}

A pandemia de HIV/Aids tem atingido mais severamente as mulheres e questões reprodutivas tornaram-se cruciais, na medida em que o risco da TMI cai para taxas inferiores a $3 \%$ em mulheres que recebem acompanhamento pré-natal adequado. Nosso objetivo central foi conhecer como mulheres, vivendo com HIV/Aids, percebem e atribuem sentido às suas decisões reprodutivas, bem como caracterizar as formas de manifestação do desejo inconsciente, a partir do prisma psicanalítico. Realizamos entrevistas com 15 mulheres vivendo com HIV/Aids, grávidas ou que tiveram filhos após a descoberta da infecção pelo HIV. Utilizamos um roteiro temático com questões sócio-demográficas, percepção da situação de maternidade concomitante à soropositividade, aspectos relativos ao desejo e expectativas perante a prevenção da TMI. Os conteúdos das falas foram trabalhados mediante análise de produção de sentido e do referencial psicanalítico. Neste referencial a questão do desejo feminino não é tomada como sinônimo de "vontade ou querer consciente", ou ainda, "como um desejo natural de ter filhos", mas sim, como uma das possibilidades de resposta do sujeito perante seu desejo inconsciente. As entrevistadas apontaram, em função da gravidez, a reorganização de sua vida pessoal, obtenção de suportes familiares e institucionais adicionais, além do bom acolhimento e seguimento para profilaxia da TMI por parte da equipe de atendimento especializado. Revelaram também, dilemas e ambivalências relativos ao desejo inconsciente da gravidez e maternidade e que suas decisões reprodutivas não são pautadas pelo provável estado sorológico da criança. O discurso dessas mulheres apresentou ainda, uma contradição quando avaliam as decisões reprodutivas de outras mulheres soropositivas como uma "loucura" ou "irresponsabilidade", enquanto procuram se des-responsabizar por suas próprias decisões. Isso ocorre porque elas estabeleceram uma relação especular idealizada com o Outro, como estratégia, para serem aceitas e, assim, tentam tamponar sua Falta constitutiva. Observamos que essa posição se evidencia nas relações conjugais-afetivas e tende a se repetir na relação com a equipe de saúde. $O$ discurso das mulheres mostrou que seu comportamento não é, necessariamente, determinado pelas orientações recebidas da equipe, mas, foi possível identificar sua necessidade de se mostrarem como aderentes ao tratamento e gratas pelo suporte institucional. Concluímos que a Psicanálise pode trazer uma contribuição para 0 campo da Saúde Pública, à medida que permite a inclusão das idiossincrasias na relação do sujeito com o outro/Outro, e, assim, viabilizar o resgate da singularidade do desejo inconsciente do sujeito em questão, além de permitir uma reflexão sobre o cuidado terapêutico e o acolhimento no atendimento a mulheres vivendo com HIV/Aids.

Descritores: HIV/Aids. TMI. Maternidade. Saúde Pública. Psicanálise. Desejo Inconsciente. 
ZIHLMANN, Karina Franco. The desire question of the pregnancy and maternity in women living with HIV/AIDS. São Paulo, 2005. [MA Dissertation in Public Health - Postgraduate Program in Maternal-infant Health of School of Public Health of USP]

\begin{abstract}
The HIV/AIDS pandemic has reached more severally women and reproductive questions have become an important issue. Mother-to-child-transmission (MTCT) dropped around $3 \%$ in women who received adequate pre-natal care. This work has the main aim to know how women living with HIV/Aids self-perceived and attribute meaning to their reproductive decisions, as well to characterize the unconscious desire presentations, using Psychoanalysis approach. This study using in-depth interviews was conducted among 15 women living with HIV/AIDS, who were pregnant or gave birth to children after the HIV diagnosis, who were attended at an Infectious Diseases Hospital and at a NGO (non-governmental organization) in São Paulo, Brazil. The data were collected using a semi-structured questionnaire regarding socio-demographic questions, and perception of motherhood concurrent the HIV seropositivity situation. The speeches were analyzed by the production of meanings and Psychoanalytic approach. In this referential, the feminine desire was not considered as synonymous of "willingness or willing conscious" or even, as "a natural desire of giving birth", but as one of the subjects" response for their unconscious desire. The interviewers stated that pregnancy allowed reorganization of their lives, additional familiar support, and special attention for health care providers during the MTCT prophylaxis. They also revealed dilemmas and ambivalences in their unconscious pregnancy desire of motherhood and their reproductive decisions were not related to the serological status of their newborns. The women pointed the other women's reproductive decision as an "insanity" or "irresponsibility", while they try to justify their own decisions. It happens because they establish a specular idealized relationship with Other, as strategy to be accepted and escape of their constitutive Fault. It is possible to observe the same position in their affective relationships and can be repeated with the health care providers. The women speech showed that their behavior was not necessarily determinate by the health care advice, but, they wanted to be seen as "good patient" e graceful for the institutional support. We concluded that Psychoanalysis could contribute for Public Heath, because the patients' idiosyncrasies can be included, and thus, allow the recover of the subject unconscious desire singularity, furthermore a reflection on therapeutic care and attention to women living with HIV/Aids. Another key issue is how to approach this group and strategies sensitive to their individualities. HIV prevention programs should take into account psychological issues, and emotional needs of the patients.
\end{abstract}

Descriptors: Acquired immunodeficiency syndrome (HIV/Aids). Mother-to-childtransmission (MTCT). Maternity. Public Health. Psychoanalysis. Unconscious desire. 


\section{Sumário}

\section{Resumo}

Abstract

Capítulo I - Introdução

1.1 - Panorama da Transmissão Materno-Infantil do HIV e sua relevância em Saúde Pública

1.2- Saúde Sexual e Direitos Reprodutivos no contexto HIV/Aids 6

1.3 - Políticas públicas e situação do atendimento

Capítulo II - A questão do desejo como eixo articulador da construção do objeto de investigação

2.1- A construção do feminino no âmbito psicanalítico 25

2.2 - O processo de "tornar-se mulher" e o Édipo feminino 30

2.3 - O feminino na teoria lacaniana 36

$\begin{array}{ll}2.4 \text { - Sexuação } & 39\end{array}$

2.5 - A sexuação na mulher e o discurso histérico 46

Capítulo III - Contribuições da psicanálise para uma leitura do objeto de investigação $\quad 50$

Capítulo IV - Hipóteses de trabalho e Objetivo $\quad 60$

4.1 - Hipóteses de trabalho $\quad 60$

4.2 - Objetivo Geral $\quad 60$

Capítulo V - Procedimento metodológico $\quad 61$

5.1 - Referencial teórico-metodológico $\quad 61$

5.2 - Desenho do estudo 68

5.3 - Critérios para seleção de sujeitos da pesquisa 68

5.4 - Levantamento dos dados $\quad 69$

5.5 - Tratamento dos dados $\quad 69$

5.6 - Aspectos Éticos $\quad 70$

Capítulo VI - Caracterização das mulheres entrevistadas $\quad 72$

$\begin{array}{ll}6.1 \text { - Apresentação das mulheres entrevistadas } & 73\end{array}$

$\begin{array}{ll}6.2 \text { - A construção do sentido das falas das mulheres: } & 157 \\ \text { entre semelhanças e diversidades. } & 157\end{array}$

6.3 - Contribuições da psicanálise para abordar a

questão do desejo e gozo em mulheres vivendo com

HIV/Aids: partindo "do sujeito" na busca do "para além do sujeito" 
Anexos

Anexo I - Autorizações para realização da pesquisa

Anexo II - Roteiro temático

Anexo III - Termo de consentimento livre e esclarecido

Anexo IV - Tabela de caracterização sócio-demográfica das entrevistadas

Glossário

\section{Lista de Figuras}

Figura 1 - Diagrama ilustrativo da relação entre a figura materna e as representações da criança. p. 32

Figura 2 - Diagrama das Fórmulas quânticas da sexuação. p. 41

Figura 3 - Diagrama da relação lógica entre a mulher e a histérica. p. 48

Figura 4 - Grafo do desejo: “Che vuoi?”. p. 53

Figura 5 - Grafo do desejo completo. p. 57

Figura 6 - Quadro de convenções utilizadas na transcrição das entrevistas. p. 70

Figura 7- Diagrama explicativo para leitura das "Linhas Narrativas". p. 72

Figura 8 - Diagrama da linha narrativa relativa à entrevistada Rita. p. 74

Figura 9 - Diagrama da linha narrativa relativa à entrevistada Ângela. p. 77

Figura 10 - Diagrama da linha narrativa relativa à entrevistada Ana Carolina. p.82

Figura 11 - Diagrama da linha narrativa relativa à entrevistada Flávia. p. 87

Figura 12 - Diagrama da linha narrativa relativa à entrevistada Mariana. p. 90

Figura 13 - Diagrama da linha narrativa relativa à entrevistada Miriam. p. 94

Figura 14 - Diagrama da linha narrativa relativa à entrevistada Bianca. p. 99

Figura 15 - Diagrama da linha narrativa relativa à entrevistada Dia. p. 102

Figura 16 - Diagrama da linha narrativa relativa à entrevistada Sílvia. p. 108

Figura 17 - Diagrama da linha narrativa relativa à entrevistada Débora. p. 114 
Figura 18 - Diagrama da linha narrativa relativa à entrevistada Eliana. p. 121 Figura 19 - Diagrama da linha narrativa relativa à entrevistada Cátia. p. 128 Figura 20 - Diagrama da linha narrativa relativa à entrevistada Celina. p. 136 Figura 21 - Diagrama da linha narrativa relativa à entrevistada Maria. p. 144 Figura 22 - Diagrama da linha narrativa relativa à entrevistada Márcia. p. 151 


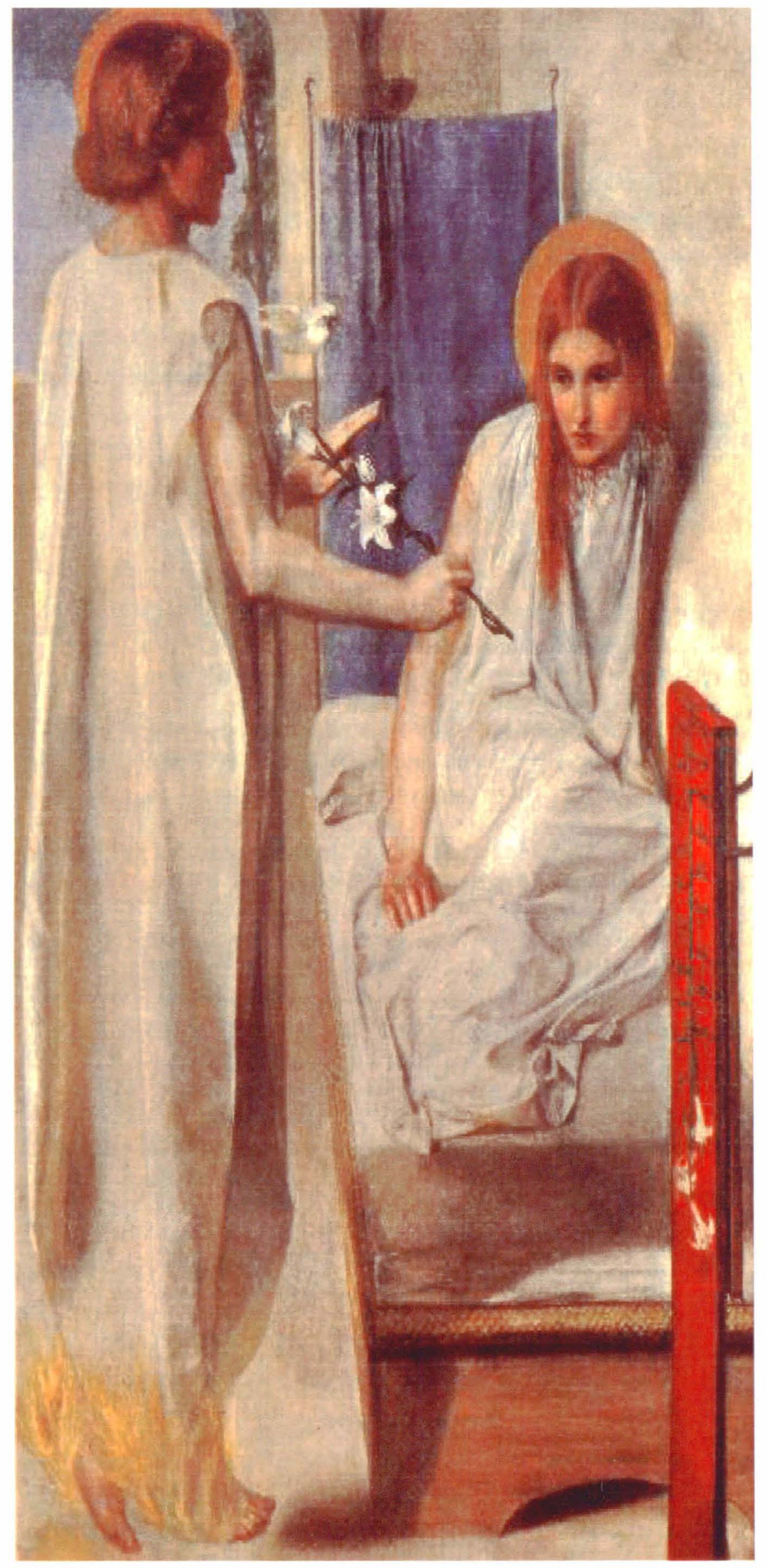

Ecce Ancilla Domini (The Annunciation), 1849, Rosetti (1829-1882) 
"Multiplicarei teus trabalhos e misérias em tua gravidez; com dor parirás os filhos e estarás sob a lei de teu marido, e ele te dominará" (Gênesis).

"E, (estando Isabel) no sexto mês, foi enviado por Deus o anjo Gabriel a uma cidade da Galiléia, chamada Nazaré, a uma virgem desposada com um varão, que se chamava José, da casa de Davi, e o nome da Virgem era Maria. E, entrando o anjo onde ela estava, disse-lhe: Deus te salve, cheia de graça, o Senhor é contigo; bendita és tu entre as mulheres. E ela, tendo ouvido essas coisas, turbou-se com as suas palavras, $e$ discorria pensativa que saudação seria esta. Eo anjo disselhe: Não temas, Maria, pois achaste graça diante de Deus, eis que conceberás em teu ventre, e darás à luz um filho, e pôrlhe-ás o nome de Jesus. Este será grande, e será chamado filho do Altíssimo, e o Senhor Deus lhe dará o trono de seu pai Davi; e reinará eternamente na casa de Jacó; e o seu reino não terá fim. E Maria disse ao anjo: Como se fará isso, pois eu não conheço varão? E, respondendo o anjo, disse-lhe: $O$ Espírito Santo descerá sobre ti, e a virtude do Altíssimo te cobrirá com a sua sombra. E, por isso mesmo, o Santo, que há de nascer de ti, será chamado filho de Deus. Eis que também Isabel, tua parenta, concebeu um filho na sua velhice; $e$ este é o sexto mês da que se diz estéril; porque a Deus nada é impossível. Então disse Maria: Eis aqui a escrava do Senhor, faça-se em mim segundo a tua palavra. E o anjo afastou-se dela".

(Evangelho de Jesus Cristo segundo São Lucas, versículos 26 a 38.) 


\section{Capítulo I - Introdução}

Nas últimas duas décadas, em todo o mundo, a pandemia de HIVIAids tem atingido, mais severamente, a população feminina. Deste modo, questões reprodutivas tornaram-se cruciais nas decisões de mulheres vivendo com HIV/Aids. Encontramos vários estudos, envolvendo a questão da transmissão materno-infantil ${ }^{1}$ (TMI) do HIV, entretanto, persistem questões relativas aos aspectos emocionais inconscientes, que subjazem esse problema. Desta forma, torna-se relevante, no âmbito da Saúde Pública, uma investigação sobre os aspectos que circundam a experiência de mulheres vivendo com HIV/Aids.

O termo "Transmissão Materno-Infantil" (TMI) refere-se ao risco que uma mulher gestante, sendo portadora de uma doença infecto-contagiosa, tem de gerar e dar à luz um bebê, com o mesmo quadro infeccioso, além do risco de infecção, através da amamentação. Mulheres vivendo com HIV/Aids podem transmitir o vírus para seus filhos, da mesma forma que em uma série de outras doenças infecciosas, como sífilis congênita, hepatite $B$, rubéola, entre outros.

Cerca de metade dos casos de Aids, notificados ao Ministério da Saúde do Brasil, é constituída pela população feminina, e uma boa parte delas encontra-se em idade fértil, muitas vezes, desconhecendo a sua situação sorológica para o HIV. De fato, SANTOS e col. (2002) lembram que é possível que uma pessoa possa vir a ser infectada, por HIV, e engravidar, no mesmo encontro sexual, como eventos concomitantes.

O acompanhamento multiprofissional de mulheres vivendo com HIV/Aids mostrou que, de alguma forma, elas engendravam uma tentativa de dar um novo sentido às suas vidas, após a descoberta do HIV. Havia algo, próprio do feminino, em suas falas: como poderiam gerar uma vida, se elas sentiam o virus, como algo "insidioso e silencioso", dentro de si? Como lidar com essas duas forças, vida e morte, como elaborar algo que supere a angústia do desconhecimento do futuro, quando já se perdeu a ilusão de que o futuro será garantido? É a partir desta perspectiva que a mulher vivendo com HIVIAids posiciona-se perante a questão de ter, ou não, ter um filho.

Sabemos que a questão da gravidez, em mulheres vivendo com HIVIAids, parece despertar polêmica, tanto nos meios acadêmicos, como na sociedade. Isso nos faz levantar, como questão, o que as leva a engravidarem e a levarem sua gravidez adiante? Quais dificuldades encontram, em seu percurso, em relação à gravidez e à maternidade? Qual a função dessa gravidez na história dessas mulheres? Como essas mulheres lidam com a possibilidade (ou o fato) de terem um filho com HIV?

\footnotetext{
'A sigla TMI é usada para designar o processo de Transmissão Materno-Infantil de doenças infecciosas, como HIV e sifilis.
} 
O que elas têm a dizer, a respeito da sua decisão de "se tornarem mães", em circunstâncias tão excepcionais?

Podemos afirmar que é um assunto relativamente novo, pois muitas idéias, a respeito da Aids, foram se modificando, principalmente, no que diz respeito às possibilidades de tratamento e prognóstico da doença, bem como à superação da idéia de que apenas as pessoas de um "grupo de risco" deveriam se preocupar com a possibilidade de infecção. Nesse sentido, torna-se interessante abordar o tema, de modo atualizado, levando em consideração que há, ainda hoje, uma grande influência de estereótipos norteando a forma de trabalho de muitos profissionais, inclusive, da área da saúde (VILLELA 1998).

Loyola (apud MERÉ-ROUCO 1999, p. 71) aponta que "é difícil alterar comportamentos sexuais, não porque eles são incontroláveis, irracionais ou desconhecidos, mas apenas porque eles seguem uma lógica diferente daquela da saúde pública".

Podemos pensar que a forma como a sociedade elou profissionais encaram o fenômeno, que buscamos estudar, pode não estar de acordo com o que, realmente, faz sentido para mulheres que vivem a situação de serem soropositivas, pois é possível apontar que há uma outra lógica, influenciando as sua decisões. Quanto a esta "outra lógica", pensamos que se trata da lógica do Inconsciente. Neste trabalho, sob o prisma psicanalítico, tivemos a intenção de traçar a relação dessa "lógica especifica do Inconsciente" com a questão do desejo de mulheres, na sua relação com a gravidez e a maternidade.

1.1 - Panorama da Transmissão Materno-Infantil do HIV, e sua relevância em Saúde Pública

O relatório da UNAIDS, de 2004, estima que há cerca de 38 milhões de pessoas infectadas pelo HIV, no mundo, das quais, aproximadamente, 36 milhões de adultos, dentre os quais, 17 milhões de mulheres e 2.1 milhões de crianças (menores de 15 anos). A maioria dessas pessoas vive em paises em desenvolvimento. Somente no ano de 2003, 4,8 milhões de pessoas foram infectadas, sendo 4,1 milhões de adultos e 630 mil crianças (menores de 15 anos). O total de mortes no mundo, até 2003 , foi de 2,9 milhōes de pessoas, das quais, 2,4 milhões de adultos e 490 mil crianças (UNAIDS 2004). A maioria das novas infecções se concentra em países pobres, localizados na África e Ásia, como, também, no Leste Europeu e América Latina.

No Brasil, o Ministério da Saúde notificou 310 mil casos de Aids, desde 0 inicio da década de 80 até dezembro de 2003. Desse total, 220 mil 783 foram verificados em homens e 89 mil 527, em mulheres. No Brasil, estimase, aproximadamente, 600 mil pessoas, vivendo com HIV. Em média, a pessoa infectada pelo HIV demora, entre 8 a 10 anos, para começar a 
desenvolver os sintomas de Aids, ou quando a contagem de células T CD4+ esteja abaixo de 350 cells $/ \mathrm{mm}^{3}$, só então ocorre a sua notificação, como um novo caso de Aids (MINISTÉRIO DA SAÚDE 2003).

A taxa de mortalidade, por Aids, no país, vem mostrando uma tendência de estabilização, desde 1999, com média de seis óbitos, por 100 mil habitantes, nos últimos três anos. Essa tendência começou a apresentar uma queda significativa, a partir de 1996, quando o governo brasileiro introduziu a política de distribuição gratuita de medicamentos anti-retrovirais, pelo Sistema Único de Saúde (SUS). Entretanto, observou-se que a queda na mortalidade é duas vezes maior entre os homens que entre mulheres (MINISTÉRIO DA SAÚDE 2003; SEGURADO e col. 2001).

Para abordar a questão da transmissão materno-infantil do HIV, é fundamental uma análise da incidência da epidemia, entre as mulheres. Os indicadores epidemiológicos revelam que o padrão de transmissão da Aids vem mudando, no Brasil. O aumento do número de casos, associado à subcategoria de exposição heterossexual, verificado, principalmente, a partir de 1991, fez-se acompanhar de uma proporção, cada vez maior, de mulheres, constatada na redução da razão de sexo. Entre 1993 e 1996, era de $3: 1$, e atingiu, gradualmente, a partir de 1996, a razão de 1:1 (MINISTÉRIO DA SAÚDE 2003; VENTURA-FILIPE e col. 2000; BARBOSA e VILLELA 1996; VERMELHO e col. 1999).

Esses dados mostram que o número de mulheres, infectadas pelo HIV, tem crescido nos últimos anos, de modo alarmante, chegando, mesmo, a se apresentar como um "fenômeno de feminização da Aids". A Aids é, atualmente, uma das principais causas de morte para mulheres brasileiras, de 25 a 49 anos, e é a principal causa de morte entre mulheres, nessa faixa de idade, na cidade de São Paulo (SEGURADO e col. 2001).

Entre 1983 e 2003, foram notificados 89,527 casos de Aids entre mulheres no pais, representando $29 \%$ do total de casos no país. Com relação à faixa etária, a maior incidência recai, em $83,4 \%$ dos casos, na faixa etária de 20 a 49 anos. Assim, embora o número de casos, no sexo masculino, seja bem mais elevado do que no sexo feminino, a tendência de crescimento dos casos, entre mulheres, vem sendo mais evidente.

Considerando-se o nivel de escolaridade, como um indicador da situação sócio-econômica, os dados revelaram um perfil de empobrecimento crescente, concomitante com a mudança do perfil de transmissão. O nível de escolaridade, para ambos os sexos, vem diminuindo progressivamente, sendo que as mulheres já apresentavam menor grau de escolaridade, desde 0 início da epidemia. A doença atinge mais mulheres com menor escolaridade ( 1 a 7 anos), representando $54 \%$ dos casos. Os casos, entre mulheres, diminuem, à medida que aumenta 0 grau de escolaridade (MINISTÉRIO DA SAÚDE 2003).

$\mathrm{O}$ aumento no número de mulheres, vivendo com HIV/Aids, tem, como conseqüência lógica, maior risco da transmissão materno-infantil do HIV, 
seja durante a gestação, parto ou pós-parto, ou, ainda, durante a amamentação (LANDRONI 2004; TESS 1997; THORNE e NEWELL, 2004; AZEVEDO, 2001; NOGUEIRA e col. 2001; RAMOS e col. 2001; CUSTÓDIO e col. 2003). O quadro apresentado justifica, portanto, a priorização da atenção à questão da saúde reprodutiva, no contexto da pandemia HIV/Aids, em uma estratégia de prevenção da TMI.

Dos casos pediátricos de Aids (considerados com menos que 13 anos de idade), no periodo de 1983 a 2003, somam aproximadamente 11 mil casos, ou seja, $3,4 \%$ do total geral do país. Destes, $84 \%$ (8843 casos) são provenientes da categoria de exposição perinatal, e o Ministério da Saúde aponta que isso se relaciona com o aumento da doença entre mulheres em idade fértil (MINISTÉRIO DA SAÚDE 2003). Se considerarmos o período de 1980, até dezembro de 2003, os casos de transmissão materno-infantil correspondem a $3 \%$ do total de casos no país ( 8900 casos) (MINISTÉRIO DA SAÚDE 2003).

VERMELHO e col. (1999) verificaram que a TMI predominava, de forma marcante, desde a década de 80 , e a diminuição observada, após 1996, provavelmente, está relacionada a um possivel impacto das intervenções, com o uso de anti-retrovirais e outras estratégias terapêuticas, na gestação e no recém-nascido. O primeiro caso de TMI, no Brasil, foi notificado em 1985. No estudo retrospectivo, realizado em São Paulo, TESS (1997) acompanhou 553 pares mãe-filho, nascidos durante o ano de 1988 a 1993. A taxa de TMI foi de $16 \%$, quando foi observado que se trata de um evento multifatorial, altamente influenciado pela gravidade do estágio da doença na mãe, pela amamentação e por intervenções obstétricas invasivas, durante a gravidez.

Em São Paulo, foi estimado que a prevalência do HIV, em gestantes, estava em torno de 0,6\%, em 2001 (DEL BIANCO 2002, apud MESQUITA e SOUZA 2003). Neste ponto, vale ressaltar a importância que assume 0 conhecimento da condição sorológica das gestantes, mediante o teste antiHIV. Em São Paulo, $80 \%$ das gestantes têm acesso ao teste, para conhecer sua condição sorológica, antes do parto, diferentemente do país, como um todo, em que apenas $50 \%$ das gestantes têm esse acesso (MESQUITA e SOUZA 2003).

O controle da epidemia de HIV/Aids apresenta-se como um desafio em andamento, mas é possível constatar avanços, no que concerne ao controle da infecção, mediante o uso de anti-retrovirais. O uso de AZT monoterapia, durante a gestação, no momento do parto e no recém-nascido, permitiu uma redução do risco de TMI, de $25,5 \%$ para $8,3 \%$, com eficácia de 67,5\% (protocolo 076 do Aids Clinical Trial Group ACTG 076/94).

A partir dos resultados do protocolo ACTG 076, a coordenação nacional de DST/Aids instituiu recomendações para profilaxia da TMI, no Brasil. Em 2001, o Ministério da Saúde do Brasil publicou um manual com 
recomendações para profilaxia da TMI do HIV², contendo informações sobre os procedimentos, políticas e recomendações, para redução da TMI. Esse manual aponta que intervenções que visam reduzir a carga viral materna, bem como a realização de parto, em condições de adequada assistência ao binômio mãe-filho, são fatores promotores da redução da TMI. O ideal seria a deteç̧ão da infecção na mulher, antes mesmo da gravidez, pois o risco da TMl fica bastante reduzido, em mulheres que apresentam um quadro clínico controlado, como carga viral indetectável, por exemplo. Nesses casos, o risco de TMI cai para taxas inferiores a $3 \%$.

A eficácia do AZT na prevenção da TMI é comprovada cientificamente, mas algumas mulheres têm reservas quanto ao seu uso, durante a gravidez, alegando medo da toxidade para o bebê; medo dos efeitos colaterais para a mãe; medo de que o uso de AZT resulte em resistência à medicação para a mãe; crença de que o AZT é desnecessário em casos de mulheres com carga viral baixa e relato de nascimento anterior de bebês soronegativos, sem o uso de AZT. Por outro lado, aquelas que aceitam o uso de $A Z T$, o fazem pela crença de que têm obrigação moral de proteger o bebê; bom relacionamento com o médico e confiança em suas prescrições; conhecimento de outros casos de gestantes soropositivas, que usaram AZT durante a gravidez e tiveram filhos saudáveis, além de histórico de terem usado $A Z T$, em gravidez anterior, e terem tido um bebê saudável (SIEGEL e col. 2001; THORNE e NEWELL 2004; ROSENFIELD 2001). Esses dados apontam a importância do bom relacionamento da equipe multidisciplinar com a paciente, acolhendo suas questões, orientando e oferecendo subsídios para que elas possam adotar uma posição favorável à promoção da saúde, tanto para si, quanto para seu(s) filho(s).

Apesar de o risco da TMI ser relativamente baixo, mediante um trabalho profilático, conforme relatamos, muitos profissionais da área da saúde, mesmo cientes desses dados, não os informam às mulheres vivendo com HIV/Aids, por temerem que isto as encoraje a engravidarem.

\begin{abstract}
"(...) os consultorios de todos os tipos de clinicas ficam ainda assombrados pelos portadores do HIV e, mais ainda, diante do seu desejo de constituir familia, que silencia e paralisa até profissionais treinados para atende-los em serviços especializados - como nos centros de referéncia para Aids que temos estudado" (PAIVA e col. 2002, p. 110).
\end{abstract}

Essa sonegação de informações, por parte da equipe médica, tem conseqüências, da ordem de saúde publica e, principalmente, psicológicas. BERER (1997) sugere que tais profissionais deveriam examinar seus próprios sentimentos em relação ao HIV/ Aids, assim como em relação à morte, gravidez, filhos e abortamento.

\footnotetext{
2 Para maiores esclarecimentos sobre o assunto, sugerimos o "Guia de tratamento: recomendações para a profilaxia da transmissão materno-infantil do HIV e terapia antiretroviral em gestantes". Brasília, Ministério da Saúde, 2001.
} 


\section{2 - Saúde Sexual e Direitos Reprodutivos, no contexto HIV/Aids}

A epidemia HIV/Aids tornou patente a necessidade da revisão dos modelos tecnicistas vigentes, cujas análises promovem dicotomias inconciliáveis entre 0 cultural e o biológico, em um processo de descontextualização reducionista. Esses modelos compreendem a sexualidade humana como uma função fisiologicamente determinada, derivada de um corpo, supostamente, universal, baseada em uma visão essencialista do homem. Por outro lado, a perspectiva do Construcionismo é uma proposta de abordagem dos fenômenos, que se preocupa em superar a idéia de patologização de categorias de análise e busca explorar os seus possiveis significados, levando em conta o contexto sócio-histórico-cultural (BARBOSA 1999).

"A construção social e cientifica da Aids, fortemente marcada por representações de classe, raça e género, deu margem a interpretaçōes preconceituosas e equivocadas, que muito dificultaram - $\theta$ dificultam - as estratégias de enfrentamento. Inclusive, $\theta$ principalmente, a falsa sensação de que, desta vez, as mulheres estavam excluídas" (BARBOSA 1999, p. 284).

No Brasil, a proposta da implantação do PAISM (Programa de Assistência Integral à Saúde da Mulher), em 1983, constituiu um modelo muito avançado, visando contemplar a saúde da mulher, em seus diversos momentos de desenvolvimento, não apenas na situação reprodutiva. Embora a implantação do PAISM não tenha sido efetiva, na íntegra, por outro lado, é de reconhecimento mundial (pela Organização Mundial de Saúde) a contribuição que esta proposta oferece para abordar a questão da saúde da mulher (BERQUÓ 2003). A Organização Mundial da Saúde (OMS), em 1988, reconheceu "saúde reprodutiva" como um conceito global de saúde aplicado à área da reprodução humana, o que inclui a preocupação com a questão do aumento das doenças sexualmente transmissiveis, como HIVIAids. BERQUÓ (2003) define saúde reprodutiva, a partir do discutido na reunião de Cairo (1994), como:

\footnotetext{
"Um estado completo de bem estar físico, mental e social em todos os assuntos concernentes ao sistema reprodutivo, suas funçōes $e$ processos, e não à simples auséncia de doença ou enfermidade. A saúde reprodutiva implica, por conseguinte, que a pessoa possa ter uma vida sexual segura $\theta$ satisfatória, tendo autonomia para reproduzir e liberdade para decidir sobre quando e quantas vezes devem fazé-10" (BERQUÓ 2003, p. 7-8).
}

A ciência ocidental, representada pelo papel particular da medicina, tradicionalmente, refere a identidade feminina a partir do seu referencial biológico, em uma tentativa de justificar a "inferioridade" das mulheres, por uma suposta "explicação" biológica. A perspectiva feminista e a discussão acadêmica, a partir do conceito de gênero, tiveram um papel fundamental de questionar esse tipo de ideologia, propondo "historicizar" a sexualidade, como um processo de construção social. Sendo assim, a sexualidade 
feminina deixou de ser vista, apenas, sob o ponto de vista do "natural, biológico", e passou a ser vista como uma construção social, que sofre influências ideológicas do contexto em que se insere (SCOTT 1995; BARBIERI 1991).

A realidade é vista como uma construção social, em que os comportamentos podem ter diferentes sentidos e significados, dependendo do seu contexto cultural e historicamente posicionado. Em relação à importância do conceito de gênero, como "construção social", SCOTT assinala:

"O género se torna, aliás, uma maneira de identificar as 'construções sociais': a criação inteiramente social das idéias sobre os papéis proprios aos homens e às mulheres. É uma maneira de se referir às origens exclusivamente sociais das identidades subjetivas dos homens e das mulheres. O género é, segundo essa definição, uma categoria social imposta sobre um corpo sexuado" (SCOTT 1995, p. 3).

A análise de gênero, fundamentada no Construcionismo, trouxe grande contribuição para uma reflexão sobre a sexualidade, nas últimas décadas, auxiliando na compreensão da pandemia de Aids. Tal abordagem mostrou-se um enfoque teórico-metodológico relevante, para revelar que a forma como a distribuição de poder se dá, na maioria das sociedades, acaba por gerar maior vulnerabilidade da população feminina. HEILBORN (1994) refere que gênero é um conceito das ciências sociais que, grosso modo, refere-se à construção social do sexo. As relações sociais são "generificadas", como aponta LOURO:

\footnotetext{
"Género é mais do que uma identidade aprendida é uma categoria imersa nas instituiçōes sociais lo que implica admitir que a justiça, a escola, a igreja, etc. são "generificadas", ou seja, expressam as relaçöes sociais de gênero)" (LOURO 1995, p. 103).

"Só podemos escrever a estória desse processo se reconhecermos que 'homem' e 'mulher' são ao mesmo tempo categorias vazias $\theta$ transbordantes; vazias porque elas não têm nenhum significado definitivo e transcendente; transbordantes porque, mesmo quando parecem fixadas, elas contém ainda dentro delas definições alternativas negadas ou reprimidas" (SCOTT 1995, p.15).
}

As relações de gênero, representadas pelas relações sociais, circunscrevem jogos de poder, conflitos e hierarquias que vão organizar concretamente e simbolicamente as relaçōes afetivo-amorosas (CAMPOS 1998). Uma série de contradiçōes e ambigüidades pode surgir com 0 processo de mudança, na condição feminina, e a família contemporânea tem que se haver com essas questōes. Entre casais, que enfrentam o desafio da problemática do HIV, essas questões são mais um fator a ser trabalhado e inserido.

"A especificidade da Aids traz, entretanto, um novo momento de conflito e novos posicionamentos que irão pór em xeque papéis 
exercidos por mulheres e homens na dinámica do casal e, portanto, também questionarão as identidades feminina e masculina. 0 casal, então enfrenta um cotidiano extremamente abalado, as referências familiares são deslocadas, os segredos conjugais são revelados, os papéis masculinos e femininos são questionados $\theta$ as identidades são postas à prova" (CAMPOS 1998, p. 92).

O conceito de Vulnerabilidade tem se mostrado útil para a compreensão dessas questões. Oriundo da área de Direitos Humanos, esse conceito foi empregado, originalmente, para designar grupos ou indivíduos fragilizados, jurídica ou politicamente. Mann e cols. (1993, apud AYRES e col. 1999) promoveram a aproximação desse conceito com o campo da Saúde Pública, para contribuir com uma reflexão a respeito do impacto da pandemia de Aids. AYRES e col. (1999) exprimem o conceito de vulnerabilidade, nos seguintes termos:

"É um conceito que expressa o esforço de produção de difusão de
conhecimento, debate e ação sobre os diferentes graus e naturezas
da suscetibilidade de individuos e coletividades a infeç̧ão,
adoecimento ou morte pelo HIV, segundo a particularidade de sua
situação quanto ao conjunto integrado dos aspectos sociais,
programáticos e individuais que os pöe em relação com o problema e
com os recursos para seu enfrentamento" (AYRES e col. 1999, p.
51 )

De fato, tal conceito tem o mérito de promover uma ampliação da tradicional abordagem comportamentalista, além de constituir uma proposta de superação da idéia de fatores de risco, ou comportamentos de risco, como contingentes da transmissão do HIV.

"O conceito de vulnerabilidade não visa distinguir a probabilidade de um individuo qualquer se expor a Aids, mas busca fornecer elementos para avaliar objetivamente as diferentes chances que cada individuo ou grupo populacional particular tem de se contaminar, dado - conjunto formado por certas caracteristicas individuais e sociais de seu cotidiano, julgadas relevantes para a maior exposição ou menor chance de proteção diante do problema" (AYRES e col. 1999, p.65).

A vulnerabilidade, individual e coletiva, ao HIV é dependente de inúmeros determinantes sociais, econômicos, biológicos, culturais, políticos, psicológicos, entre outros, numa relação sinérgica de fatores. No presente trabalho, gostariamos de ressaltar o aspecto da vulnerabilidade feminina, o que nos remete à forma como se processam as dinâmicas de poder nas sociedades contemporâneas, constituindo uma reflexão que perpassa questōes de gênero (Pitangy, apud BARBOSA 1999; VENTURA-FILIPE e col.. 2000; VERMELHO e col. 1999).

No que concerne a esse aspecto, Barbosa (2003, in BERQUÓ 2003) enfatiza que a mulher é mais vulnerável, sob ponto de vista fisiológico, pois existe maior contato entre mucosas e exposição ao sêmen (que em geral apresenta maior concentração viral). Essa vulnerabilidade fisiológica tornase mais veemente, se levarmos em conta que outras doenças, sexualmente 
transmissiveis, podem interferir nos mecanismos naturais de proteção vaginal, acarretando maior risco para DSTs.

Para articular os conceitos de saúde sexual e gênero com a noção de direitos reprodutivos, não podemos deixar de refletir que tal direito implica tanto o desejo de não ter filhos (anticoncepção, como um direito), quanto o direito de engravidar e levar a gestação a termo. Quanto a este direito, estamos mais acostumados a vislumbrá-lo, sob o prisma feminino, entretanto, é possivel levar em consideração o aspecto masculino, pois, em última instância, a interação dos mesmos tem, como conseqüência, a construção da descendência.

Quanto ao direito de não ter filhos, o conceito de anticoncepção implica tecnologia, política pública, saúde, qualidade de vida, direitos $e$, fundamentalmente, práticas sociais da vida cotidiana, as quais se passam no âmbito da intimidade da relação sexual entre homens e mulheres. A contracepção constitui, assim, um instrumento básico na vivência dos direitos reprodutivos (ÁVILA 2000). No Brasil, assim como em outros países latino-americanos, o acesso à contracepção não é respeitado, apesar de constituir um direito de cidadania, garantido pela Constituição Brasileira, de 1988. O que se observa é um quadro social grave: uso indiscriminado de esterilização feminina e pilula anticoncepcional; a falta de oferta de métodos reversíveis e de práticas educativas nos serviços públicos de saúde; desinformação sobre métodos anticoncepcionais. Todos esses fatores se inserem em um contexto de acentuada pobreza e relações de gênero desiguais (ÁVILA 2000).

\begin{abstract}
"No entanto, dada a forma perversa como tem sido tratada a anticoncepção no país, faz-se necessário também um sério trabalho educativo com profissionais de saúde e com a população, a fim de superar a cultura do método único e irreversivel e reinstaurar uma demanda diversificada $\theta$ democratizada" (ÁVILA 2000, p.2).
\end{abstract}

A idade média de esterilização feminina, no Brasil, caiu de 34, para 29 anos. Cerca de $40 \%$ das mulheres casadas são esterilizadas, e apenas $4,4 \%$ das mulheres, que adotam algum outro método contraceptivo, contam com parceiros, que utilizam preservativos masculinos. Cerca de $51 \%$ das jovens, entre 15 e 19 anos, que não freqüentam a escola, já têm filhos. Esses índices alarmantes remetem para a dificuldade de negociação das mulheres, quanto às ações contraceptivas, à falta de informação sobre os direitos sexuais, educação e possibilidade de planejamento familiar (BARBOSA 1999; BARBOSA e VILLELA 1996).

PAIVA e col. (2002) sugerem que existe um estigma anti-familia, associado a pessoas vivendo com HIVIAids, o que pode indicar uma violação dos direitos reprodutivos. Um estudo comparativo, entre São Paulo e Porto Alegre, investigou a incidência da realização da laqueadura no pósparto, em mulheres vivendo com HIV. Observou-se que, em São Paulo, há uma cultura médica favorável à esterilização definitiva, com acesso facilitado 
aos serviços, para as mulheres soropositivas. As mulheres soropositivas foram liberadas do cumprimento da lei, que proibe esterilização no pósparto, e os critérios foram flexibilizados, autorizando esterilização para mulheres com menos de 25 anos, após nascimento do primeiro filho, com ou sem consentimento do parceiro (BARBOSA e KNAUTH 2003).

O que se observa, na prática, é que mulheres se valem de estratégias sócio-culturalmente construídas, para tentar lidar com esse contexto. Muitos estudos têm sido conduzidos para compreender a forma como as mulheres "negociam" a contracepção, a maternidade e comportamentos de prevenção às DST/Aids, com seus parceiros. BARBOSA (1999) faz uma análise desse processo de negociação sexual, como um processo de "barganha", conceituando-o como:

"Processo de barganha com vistas a obtencaão de um acordo que viabilize a adoção de um comportamento protetor, em relação à infecção pelo HIV, e que por alguma razão é inaceitável para um dos integrantes." (BARBOSA 1999, p.77)

Nessa perspectiva, a idéia de "empowerment" ou "empoderamento" constitui um atributo individual, que torna a mulher capaz de melhorar sua capacidade de se comunicar, ter maior acesso às informações para manter e promover sua saúde, possuir habilidades ("skills") específicas para perceber condições de risco e adotar comportamentos preventivos. Mas, a experiência tem mostrado que, a adoção desses comportamentos e valores, está atrelada a uma série de representaçōes das mulheres, a respeito de seu papel na relação amorosa, bem como a questōes de gênero (BARBOSA 1999).

A partir da proposta de empoderamento, a mulher deixa de ser "vitima" na relação com o homem, passando a ser agente da sua sexualidade. A sexualidade deixa de ser um simples instrumento de reprodução e torna-se um canal de comunicação e um meio de troca de necessidades e desejos, além de possibilidade de expressão de prazer. Entretanto, não podemos deixar de apontar que esse exercicio não é amplamente incorporado pela sociedade, gerando situações, em que a sexualidade e a possibilidade reprodutiva, ainda, são usados como instrumentos de manipulação social, ou, mesmo, como formas de obtenção de um status pessoal, dentro das relações afetivas (BARBOSA 1999).

O preservativo feminino, como uma opção segura para a saúde da mulher e como método contraceptivo, cuja escolha dependa mais autonomamente da mulher, apesar de ter boa aceitação, por parte dos casais, por ter um custo alto, poderá ser inacessivel para a maioria das mulheres de paises pobres (BARBOSA 1999). Os debates sobre o assunto nos auxiliam a pensar que o preservativo feminino não substitui o masculino, mas ambos podem ser usados, alternadamente, podendo propiciar a divisão de responsabilidades, quanto às questōes reprodutivas, no casal. 
“Daqui para frente, cada vez mais será difficil pensar em prevenção de gravidez totalmente desvinculada da prevenção da Aids. É bastante absurdo pensar que as mulheres terão que usar dois métodos para ter a garantia de uma sexualidado mais segura. E não é factível" (BARBOSA e VILLELA 1996, p.27).

O modelo de anticoncepção, adotado no Brasil, tem se mostrado calcado em uma postura autoritária, por parte de profissionais de saúde. Eles assumem que a usuária do serviço de saúde não quer, ou não deve ter filhos, e não é capaz de aprender a lidar com sua fertilidade, de outro modo que não pela inibição. Nesse prisma, a assistência se baseia na medicalização, transformando a decisão reprodutiva em um processo que visa ao interesse político e econômico (VILLELA 1997; BASSETT 2001).

TANAKA e ALVARENGA (1999), também, lembram que a assistência médica, voltada apenas para o aspecto tecnicista, conduz a um impasse, na abordagem do sujeito.

\begin{abstract}
"Apresentando-se como processo de medicalização da assistência médica na vida sexual e reprodutiva, o emprego da tecnologia assume, progressivamente o estatuto de objeto complexo por apropriar-se não somente do corpo da mulher, mas de sua própria vida, porém desvalorizada e a-historicizada" (TANAKA e ALVARENGA 1999).
\end{abstract}

Outro aspecto relevante, para abordar a questão da negociação sexual, em sua relação com a contracepção e risco de infecção por DSTs, diz respeito à forma como os casais estruturam suas relações afetivosexuais. A sociedade contemporânea se especializou na busca pelo hedonismo e erotismo, como formas primordiais de expressão pessoal (DUARTE 1999; MERÉ-ROUCO 1999), criando a idéia de que uma situação de risco poderia servir de "prova de amor". Quando envolvidas emocionalmente, mulheres deixam de perceber comportamentos de risco, como uso de drogas injetáveis, por parte de seu parceiro (VENTURA-FILIPE e col. 2000), expondo-se, elas mesmas, ao risco de infecção. Alguns casais sorodiscordantes não usam preservativos, consistentemente, sob a alegação de que querem "compartilhar a condenação (HIV), por amor" (SANTOS e col. 2002).

Em função do tipo de vínculo afetivo, entre alguns casais estáveis, ou não, é possível observar que, muitas vezes, em nome de um ideal de relação amorosa, as mulheres se expõem, conscientemente, à situação de risco, tanto para infecção pelo HIV, quanto ao risco de engravidar.

"(...) é importante considerarmos que a sexualidade feminina, ao ser construida no sistema sexo/género como impura e passiva, só pode ser exercida 'livremente' com a sanção do amor e a partir do desejo do outro. Isso traz como conseqüência, entre outras, a dificuldade da incorporação da idéia de prevenção, pois o verbo amar, aos ser conjugado no feminino, adquire um forte sentido de abnegação, de negação de si mesma em função do desejo do outro, e a prevenção implica interpor um objeto ou uma racionalidade ao desejo, que é do 
outro, podendo se configurar, portanto, para muitas mulheres, como a antítese do amor" (BARBOSA e VILLELA 1996).

Para BARBOSA e VILLELA (1996), a maternidade adquire um sentido de reasseguramento narcísico, bem como o papel de garantia de sobrevivência, colocando as mulheres na dependência do parceiro. Nesse sentido, o lugar da mulher, em nossa sociedade, ainda é visto como "passivo", como um objeto de desejo do outro. Nessa visão androcêntrica, toda reflexão feminina, a respeito da contracepção, ou, mesmo, seu papel no processo reprodutivo, ficaria submetida ao discurso dominante. $\mathrm{Na}$ economia de trocas simbólicas, as mulheres adotam uma postura de "cumplicidade consentida", em relação ao suposto desejo masculino (BARBOSA e VILLELA 1996; VENTURA-FILIPE e col. 2000).

O advento da descoberta do HIV, na vida de um casal, tem implicações importantes. O trabalho de CAMPOS (1998) analisou as histórias de vida de mulheres portadoras do HIV e mostrou que elas procuram construir estratégias, que promovam a manutenção do vínculo conjugal. Observou-se que, apesar de a grande maioria das mulheres permanecerem ao lado de seus companheiros, não ocorre, necessariamente, a manutenção do vínculo afetivo-sexual. A reação diante da descoberta do HIV pode ser caracterizada por um "choque inicial", que interfere na própria identidade da mulher. Mas, a situação afetiva, anterior à descoberta do HIV, pode influenciar, pois, em uma relação permeada pelo afeto, cumplicidade e reciprocidade de cuidados, comumente, instaura-se um sentimento de apoio e solidariedade, no casal.

A reação da mulher soronegativa difere, sensivelmente, daquela da soropositiva. A mulher soropositiva enfrenta um momento de assunção de uma nova identidade social, vivenciando um momento de sofrimento, revolta e mudanças em sua vida psíquica e afetiva. Muitas vezes, a doença ou morte do parceiro e/ou filhos faz com que a mulher tenha que se haver com a possibilidade da própria enfermidade ou morte. Mulheres soronegativas, em geral, mostram-se mais condescendentes com a doença do parceiro. Por outro lado, a forma de infecção do parceiro pode incitar uma crise na identidade feminina, como no caso de parceiros que se infectaram em relações homossexuais (CAMPOS 1998).

REIS (1998) lembra a teoria de PARSONS, sobre o papel do doente, a qual propōe que uma doença pode ser melhor "tolerada socialmente", se 0 sujeito, em questão, não se expôs, voluntariamente, à mesma e, além disso, quer dela se livrar e procura ajuda competente. Podemos relacionar essa teoria com as observações de KNAUTH (1999), pois, segundo ela, mulheres vivendo com HIV/Aids procuram realizar um processo de demarcação das diferenças, em relação aos demais doentes de Aids, estabelecendo, para si, uma espécie de "legitimidade da contaminação". Parece ser importante demarcar essa "involuntariedade", que possibilita que elas assumam um papel de "vítimas de infecção", que as diferenciam de outras mulheres, com comportamentos considerados "inadequados". 
O papel de esposa é "suportar, resignadamente, seu destino". Essa atitude parece indicar a desculpabilização do parceiro (principalmente se ele for falecido), colocando o comportamento sexual masculino, como sendo "naturalmente promiscuo" e, por isso, socialmente justificado (KNAUTH 1999). KNAUTH (1999) aponta, ainda, que uma atitude bastante comum é a negação da doença, pois as mulheres referem um total "esquecimento" da doença, uma vida "normal". A manutenção de tal "normalidade" pode ajudar a mascarar sentimentos de ambigüidade, angústia e culpa, que podem relacionar-se com crises na relação e dúvidas, quanto à forma de infecção do parceiro, ou dela própria. Instaura-se um silêncio, que incita à manutenção do status quo, e a irreversibilidade da situação é assumida, para "não piorar a situação". Sentimentos de hostilidade, raiva, culpa, depressão e medo podem ser interpretados como manifestação de culpa $e$, por isso, são vistos como uma espécie de "futilidade perigosa".

A mulher, também, passa a contar com os "recursos" que se mostrarem disponiveis. Ocorre um resgate do status social de filha, em uma reaproximação com sua família de origem, contatos com Organizaçōes nãogovernamentais, retomada da capacidade produtiva, entre outras. Estabelecem-se novas alianças, que possibilitem um melhor cuidado de si ou do companheiro, entretanto, parece haver um cuidado em manter a questão da Aids, como um "segredo bem guardado", e que só pode ser revelado em condiçōes muito especiais, ou que proporcionem algum tipo de vantagem, pois o medo da exposição social da sua condição sorológica é um fantasma, que se impõe diariamente (KNAUTH 1999).

O advento da Aids pode gerar a inversão do jogo de poder, implícito nas relações de gênero, anteriormente estabelecidas. O espaço doméstico é reorganizado, exigindo novos arranjos, e expondo dificuldades, anteriormente implícitas. O homem adoecido torna-se "fragilizado" e, por isso, a mulher passa a ter um papel de superação da sua condição "natural de passividade". Tal inversão é sentida como uma sobrecarga para as mulheres, $e$ isso pode ser enfrentado, com resignação ou hostilidade.

“As batalhas, silenciosamente travadas, tornam-se explicitas com a
soropositividade. A fragilização e dependéncia do homem modificam
as relaçōes de poder e revolucionam as estruturas tradicionais do
casamento, tornando necessário novas interpretaçöes dos papéis
de gênero e novas determinaçōes sobre o 'ser homem' ou 'ser
mulher"' (CAMPOS 1998).

A mulher, também, é socialmente pressionada, no sentido de assumir uma função de cuidadora (mãe, enfermeira), algo que é considerado próprio da identidade feminina. Quando a mulher tem que optar por cuidar de um companheiro doente ou de seus filhos, é comum que priorizem o cuidado com o parceiro (CAMPOS 1998). 
A mulher vivendo com HIV, que tem filho(s), provavelmente, terá que lidar com situações, como a incerteza de que o filho esteja efetivamente infectado (há uma espera de, aproximadamente, 18 meses, para se confirmar a infecçāo em bebês); o medo de que seu contato com o bebê possa transmitir o vírus (através da amamentação, que, obviamente, deve ser evitada); medo de que a mãe possa vir a transmitir o vírus no contato social, ou por meio dos cuidados cotidianos de higiene; dificuldades de compartilhar com outras pessoas sobre o HIV, por temer que a criança seja vítima de preconceito; medo de que percam sua condição de assintomáticas e não possam cuidar, efetivamente, de seus filhos, entre outros (SANTOS 2002; KNAUTH 1999; CAMPOS 1998). No caso de mulheres, com estilo de vida considerado "caótico", como moradoras de rua ou usuárias de drogas lícitas e ilícitas, há, ainda, a possibilidade de vivenciarem dificuldades para cuidarem de si e/ou dos filhos (BERER 1997).

Com o nascimento do bebê, a impossibilidade de amamentar torna-se uma evidência de que "algo nesta gravidez não é normal". Nesse sentido, o primeiro "sintoma" do HIV é a não amamentação, pois traz visibilidade a algo que foi, cuidadosamente, mantido em segredo. Surge uma série de "desculpas", e um repertório é cuidadosamente preparado para justificar a situação "aos outros", sem, contudo, aplacar a angústia que as mulheres sentem, por não poderem realizar o que consideram a "verdadeira expressão da maternidade" (CAMPOS 1998).

A doença impõe constrangimentos, como, por exemplo, enfrentar desaprovação social e de profissionais, pela gravidez, impondo críticas de premissa moral. Mas, o que o discurso das mulheres revela, é que a manutenção da atividade reprodutiva pode assegurar o fortalecimento dos laços consangüíneos e com parceiro. O status de mãe pode restaurar a identidade social dessas mulheres, como "mulheres de respeito", e a matemidade pode configurar-se como um desafio, em face da doença, uma razão de honra e luta. "Estar grávida" pode ser equivalente a "estar saudável", o que implica "desaparecimento da doença" (CAMPOS 1998; KNAUTH 1999).

Várias pesquisas indicam que a condição sorológica da mulher, ou, mesmo, o fato de ter desenvolvido Aids, não a impede de engravidar e/ou desejar um tilho (SOWELL e col. 2002; LANDRONI 2004; PAIVA, LIMA, SANTOS, VENTURA-FILIPE E SEGURADO 2002; SANTOS 2002). Os fatores que influenciam uma mulher soropositiva, quanto à decisão de engravidar, denotam a complexidade do problema. O trabalho de SOWELL e col. (2002) refere que as decisões reprodutivas das mulheres são baseadas em fatores relacionados com circunstâncias de vida, número prévio de filhos sob seus cuidados, influência do relacionamento com parceiro, fatores psicossociais (como necessidade de ser amada), desejo de deixar alguma coisa de valor no mundo e crenças religiosas. Foram associados à intenção de engravidar: menor idade, maior motivação para criar filhos, menor percepção do HIV, como um perigo para si ou para o bebê, menos 
sintomatologias ligadas ao HIV, maior orientação para adotar tradicionais papéis de gênero e maior dificuldade de enfrentamento dos aspectos ligados ao HIV. É interessante notar que a maioria das entrevistadas estava na condição de alto risco para gravidez, pois eram sexualmente ativas, sem, contudo, usarem métodos contraceptivos.

SANTOS (2002), também, observou uso inconsistente de preservativos. Mulheres com parceiros soropositivos tendem a fazer o uso inconsistente (nunca, raramente ou às vezes) do preservativo masculino, com uma freqüência maior do que mulheres com parceiros soronegativos. A maioria das mulheres entrevistadas $(63 \%)$ usava métodos anticoncepcionais hormonais, para controle da natalidade e, após o diagnóstico de HIV, houve a passagem do método hormonal para o preservativo, porém de forma inconsistente. A minoria $(7 \%)$ delas fazia uso de proteção dupla (preservativo, associado a algum outro método contraceptivo). Em outro estudo, SANTOS e col. (2002) observaram que as entrevistadas receberam orientação de médicos, sobre o uso de preservativo, sem qualquer discussão englobando a questão do método contraceptivo, o que as levavam a usarem o preservativo, como método contraceptivo, sem se preocuparem com a questão da proteção dupla.

Quanto ao aspecto, que envolve as decisōes reprodutivas, SANTOS (2002) observou que, das 148 mulheres entrevistadas, em um serviço de atendimento especializado em DST/Aids, $29 \%$ expressaram, abertamente, desejarem ter filhos. Metade das mulheres, que afirmaram não desejarem ter filhos, em função do medo da doença, para si e/ou para seus bebês. No caso das que expressaram o desejo de terem filhos, esse desejo, não necessariamente, concretizar-se-ia em gestação. Em sua maioria, expressaram o receio de que seus bebés nasçam soropositivos, além de medo da falta de apoio e estigmatização, pois temem que o preconceito se estenda a seus filhos. Das 117 mulheres, que responderam não desejarem ter filhos, $20 \%$ referiram não usarem método contraceptivo. É interessante destacar que Santos observou uma associação positiva entre pensar em ter filhos e ter motivação para lutar pela vida, pois $44 \%$ das mulheres referiram que seus filhos constituem o principal motivo, que as mantém lutando pela vida.

Vemos, portanto, que o comportamento e as decisões reprodutivas, dos sujeitos envolvidos, podem adotar sentidos que vão para além do modelo tecnicista, vigente em alguns âmbitos da Saúde Pública. Em função disso, uma abordagem, abrangendo o campo de políticas públicas de atendimento à população de mulheres, no que diz respeito à saúde reprodutiva, torna-se válida, para melhor compreensão de nosso objeto de investigação. 


\title{
1.3 - Políticas Públicas e situação do atendimento
}

A situação de gravidez é um momento crítico na vida da maioria das mulheres (SOIFER 1980), principalmente, quando há a possibilidade de ter sido infectada pelo HIV. De modo geral, a população feminina, vivendo com HIVIAids, é alvo de inúmeros e complexos fatores estressores, como dificuldades sócio-econômicas, ideologias e questōes de gênero, que podem desencadear, freqüentemente, dificuldades no seu processo de adesão ao tratamento, bem como impacto negativo na auto-estima e percepção da sua capacidade de autocuidado.

COSTA DIAS (1999), bem como VERMELHO e col. (1999) apontam que o silêncio é um fator importante, que norteia 0 atendimento às mulheres soropositivas, mais especificamente, no contexto que envolve questōes sobre a sexualidade feminina, gravidez e Aids. Esse silêncio se relaciona com a dificuldade no reconhecimento da ambigüidade entre o direito à maternidade versus o lugar destinado ao desejo feminino, em condutas e ações médicas.

\begin{abstract}
"Querer tem filhos é um desejo legítimo de homens a mulheres: quer por razōes religiosas, para dar sentido à vida, por causa das normas para os gêneros em que foram socializados, para a construção de sua identidade feminina ou viril. (...) Sem desqualificar o medo dos profissionais da saúde que se angustiam tanto pela gravidade quanto pelo estigma da doenca, como diante da possibilidade, ainda que pequena com certos cuidados, de uma criança nascer soropositiva para HIV, porque essa angústia se traduz na negação do direito à informação $\theta$ ao aconselhamento que acolheria o desejo e estimularia a decisão informada dos pacientes?" (PAIVA $\theta$ col. 2002, p. 127).
\end{abstract}

No mundo, a forma, como as mulheres lidam com essas questões, mostra que, no que se refere ao sujeito, o enfrentamento do HIV pode revelar algumas surpresas. BERER (1997) relata que algumas mulheres africanas e asiáticas têm expressado a determinação de terem mais filhos, do que teriam normalmente, para garantir que alguns sobrevivam. Isso é ainda mais comum em comunidades, que apresentam elevada taxa de mortalidade infantil (de 10 a $30 \%$ (?)), como no caso de alguns países do continente Africano. Em Ruanda, há um provérbio que diz "Para uma criança morrer, ela precisa primeiro nascer".

Mulheres vivendo com HIV podem viver intensos sentimentos de conflito, fazendo com que as incertezas, comuns da gravidez, sejam mais problemáticas. Se a mulher já estiver grávida, qualquer decisão que vier a tomar será sentida como um erro: pode haver culpa, se a criança nascer com HIV, e incerteza de que o bebê estava infectado, caso a mulher decida realizar um aborto (BERER 1997).

Em países africanos, a condição sócio-econômica, que é, muitas vezes, de absoluta miséria, a falta de acesso ao tratamento, para o controle da infecção pelo HIV, além de sérias questões de gênero (como violência 
doméstica e social), fazem com que o acesso feminino aos procedimentos de prevenção da TMI seja ainda mais dificultado. Diante de tal quadro, algumas mulheres preferem não conhecer sua situação sorológica, durante ou logo após a gravidez, uma vez que isso envolveria muitos sentimentos conflituosos, que ficam, muitas vezes, pendentes (PERLEZ, apud BERER 1997; THORNE e NEWELL 2004; SOWELL e col. 2002; SALMON 2002; ROSENFIELD 2001; BASSETT 2001; MITKA 2002).

"Para muitas mulheres, a maternidade é vista como a afirmação da
vida diante da miséria, da dependência das drogas, do racismo, da
Aids e talvez da perda de outras crianças. Além disso, mesmo um
indice de transmissão perinatal de 50\% é visto como um risco
aceitável para algumas mulheres" (O'LEARY e CHENEY 1993, p. 62).

A discriminação contra grávidas, com HIV, assume várias formas de expressão. Em alguns países, há relatos de casos em que mulheres vivendo com HIV/Aids foram coagidas a abortar, além de esterilização compulsória naquelas em idade fértil (BERER 1997). Em casais inférteis, vivendo com HIV, o tratamento para infertilidade é, muitas vezes, negado, pois acreditam que o médico deve tomar decisões morais, sobre o que é do interesse do paciente e/ou bebê, além de considerar que, ao possibilitarem esse tratamento, estariam compartilhando da responsabilidade do nascimento de uma criança, com HIV, e/ou de uma criança órfã (BERER 1997).

Apesar de o número de mulheres, vivendo com HIVIAids, ser cada vez mais significativo, a consciência do impacto que a epidemia tem nesta população, ainda é pequeno, e isso pode ser observado na estruturação dos serviços de apoio à saúde da mulher (O'LEARY \& CHENEY 1993). No Brasil, há "desarticulação" entre os serviços, promovendo uma "separação" entre os programas de saúde da mulher e os programas de prevenção de DST/Aids. VILLELA (1998) aponta que essa "desarticulação" é, na verdade, uma dissociação: existem entraves para uma efetiva integração entre saúde reprodutiva e DST/ Aids, relacionados à estrutura de inserção dessas ações nos setores governamentais, responsáveis pela saúde da população feminina. O setor de promoção da saúde da mulher é dotado de recursos financeiros, dinâmica e funcionamento, independente do setor de prevenção e assistência às DST/Aids, e os recursos não chegam à rede básica de saúde, tornando as açōes preventivas de baixo impacto ou, mesmo, inócuas.

O papel do ginecologista, no tocante à saúde da mulher, é notoriamente significativo, pois é a esse profissional que as mulheres recorrem, periodicamente, na busca de um acompanhamento médico que é, ao mesmo tempo, específico e amplo. A demanda, portanto, é bastante ampla, abrangendo, desde a questão clínico-fisiológica, até dúvidas quanto à sexualidade, planejamento familiar, disfunçōes sexuais, doenças sexualmente transmissiveis (DST), entre outras. A gestante, que iniciou um pré-natal, poderá ser "convidada" a realizar o exame "anti-HIV" e tal situação ser desencadeante de uma série de angústias, que podem, ou não, ser acolhidas pela equipe multiprofissional. Quando a paciente apresenta um 
resultado de teste positivo para HIV, instala-se uma situação complexa, e que pode vir a ser enfrentada de várias formas, variando da mais positiva $e$ amadurecida, à forma mais disruptiva. Cabe ao profissional da área da saúde oferecer o suporte necessário para este momento tão delicado na vida da mulher.

Um estudo, conduzido nos Estados Unidos da América, em uma coorte de baixa prevalência para HIV, constatou que, cerca $62 \%$ dos clínicos indicavam, de forma rotineira, o teste para pacientes em risco, mas apenas $46 \%$ indicavam para aqueles, sem fatorés de risco evidentes. Os autores identificaram o medo de possiveis resultados positivos, como maior barreira para aceitação do teste, mas esse fator parece estar relacionado com baixo conhecimento dos benefícios que a testagem pré-natal do HIV pode trazer, tanto para a paciente, quanto para o bebê. Esses dados sugerem que profissionais da área da saúde têm concepções a priori, no que concerne ao perfil de paciente, que supõe ter "necessidade" de ser testada para o HIV (MCKINNEY, MCSPIRIT E POMEROY 2000).

PAIVA e col. (2002) citam um estudo, não publicado, de OLIVEIRA (2002), sobre como as demandas reprodutivas dos pacientes soropositivos são desconsideradas e invisiveis, do ponto de vista das equipes de saúde. OLIVEIRA (2002, apud PAIVA e col. 2002) aponta que as equipes formulam decisões reprodutivas dos pacientes, como um "problema", e privilegiam a criação de espaços voltados, unicamente, para o controle da TMl e controle clínico da infecção pelo HIV. Profissionais que acompanham a gestante soropositiva ficam constrangidos em falar sobre o HIV, pelo fato de que isso implica abordar questões que envolvem a subjetividade da portadora. Fora do consultório, reiteram a desaprovação da opção da mulher, vivendo com HIVIAids, de ter filhos.

\begin{abstract}
"(a intervenção é)... pontual quando do aparecimento da gravidez ou da formulação de questões por parte dos usuários, intervenção essa sempre mediada pelo julgamento moral do profissional. (...) Os profissionais procuram apoiar seus discursos na normatividade do aparato tecnocientifico, mas associam esse ao julgamento vinculando um plano moral dos diferentes modos de andar a vida das usuárias, como é demonstrado em seus comentários: as mulheres continuam engravidando, apesar do HIV e há indicação da laqueadura associada ao número de filhos." (Oliveira 2002, apud PAIVA e col. 2002, p. 127)
\end{abstract}

Uma pesquisa realizada pelo Enhancing Care Initiative (ECl; SEGURADO e col. 2001; MARQUES, LATORRE, DELLA NEGRA, PLUCIENNNIK e SALOMÃO 2002; PAIVA 2001) sobre Vulnerabilidade e Cuidado às Mulheres Vivendo com HIV/Aids, realizado em São Paulo, Santos e São José do Rio Preto, envolveu 1184 mulheres, dentre as quais, 116 tinham dado à luz, em 1998, e que revelaram uma falha na qualidade da informação sobre a prevenção da TMI, no período pré-natal. A pesquisa mostrou que a maioria expressiva das entrevistadas (94\%) havia feito o prénatal e comparecido a mais de quatro consultas (em $83 \%$ dos casos). Do total das mães entrevistadas, $17 \%$ não haviam recebido qualquer orientação 
sobre o teste do HIV, durante o pré-natal, e a parcela para qual o exame foi oferecido, metade (56\%) não recebeu qualquer explicação sobre o motivo e/ou necessidade do teste. Da parcela, que recebeu explicaçōes sobre o teste, $24 \%$ não compreenderam o risco que envolvia seus bebês e $16 \%$ não compreenderam a necessidade do uso da Zidovudina. A pesquisa, também, revelou que $43 \%$ das entrevistadas conheciam seu status sorológico positivo para o HIV, antes de engravidar, $36 \%$ o souberam durante a gestação e $20 \%$, após o nascimento do bebê. Chama atenção o fato de que $17 \%$ das entrevistadas amamentaram, independentemente da consideração do risco de TMI.

Ainda nesse estudo, quanto ao aspecto do aconselhamento pré e pós-teste, observou-se que apenas $42 \%$ das gestantes portadoras do HIV receberam algum tipo de aconselhamento pré-teste. Apenas $63 \%$ das entrevistadas receberam aconselhamento pós-teste e a maioria das mulheres que não receberam este tipo de apoio, haviam feito o teste em bancos de sangue, bancos de leite ou em serviços particulares de atendimento médico. Constatou-se, portanto, que o serviço de aconselhamento, ainda, não é, nem sistemático, nem, algumas vezes, sequer previsto nos serviços para DST/Aids (SANTOS e col. 2001). Pacientes, testadas em maternidades, ou em senviços privados de atendimento médico, afirmaram terem sentido discriminação, crítica e indiferença no tratamento dado pelos provedores de saúde $(\mathrm{ECl}$, SEGURADO e col. 2001).

Um estudo realizado no Hospital Clementino Fraga, do Rio de Janeiro, acompanhou, desde 1995 a agosto de 2000, uma coorte de mulheres soropositivas, e seus resultados mostraram diagnóstico da infecção pelo HIV em 145 crianças, e a adesão ao tratamento intraparto, tratamento do bebê e uso do leite em pó foi de $88,2 \%$. O uso de AZT intraparto ocorreu em 92, 6\% dos casos, e o indice de TMI foi de 4/ 125 (ou $2,75 \%$ ). O fator significante para TMI foi a falha no uso do AZT intraparto, bem como baixo CD4 da mãe, alta carga viral e ruptura de membranas por mais de 4 horas (NOGUEIRA e col. 2001). RAMOS e col. (2002) entrevistaram 209 mulheres, no Hospital Materno-infantil Presidente Vargas, em Porto Alegre. Cerca de $83 \%$ foram previamente testadas para o HIV e $17 \%$ não o foram. Do total de entrevistadas, $96 \%$ tiveram, pelo menos, uma visita pré-natal e $81 \%$, três ou mais consultas pré-natais, sendo que $6 \%$ delas relataram que não foi oferecido o teste para HIV, e $2 \%$ não souberam informar se o teste foi, ou não, oferecido.

Essas pesquisas nos ajudam a pensar que o modelo de atendimento, centrado no médico, e a atenção voltada para o controle da infecção, mediante 0 uso de dispositivos tecnológicos, embora eficaz, do ponto de vista epidemiológico, desconsiderou as intersubjetidades envolvidas. LANDRONI (2004) assinala a necessidade de elaboração de tecnologias que, de fato, levem em consideração o cuidado, nas práticas assistenciais propostas. Embora, em sua pesquisa, as entrevistadas tenham avaliado 
positivamente os serviços, em que são acompanhadas, houve a identificação de dificuldades no acolhimento das questōes relacionadas à saúde reprodutiva (LANDRONI 2004; SANTOS e col. 2002; PAIVA e col. 2002). Algumas mulheres declararam sua intenção de engravidar para os médicos que as assistiam, e estes procuraram dissuadi-las, ou respeitaram sua vontade, sem, contudo, denotarem empenho na compreensão ou participação em seu projeto (LANDRONI 2004).

\begin{abstract}
"Observa-se que mesmo nos centros de exceléncia que temos estudado, organiza-se um atendimento que parece favorecer uma certa solidão dos pacientes. Fortemente marcados pelo modelo centrado no atendimento médico (e do trabalho médico como foco na infecção), os centros supracitados não são espaços familiares, não se constituem como centros de auxilio $\theta$ apoio à vida em familia." (PAIVA e col. 2002, p.125)

"Nós (equipe de saúde) fingimos que sua sexualidade e seu desejo (consciente ou inconsciente) de ter filhos não existe e falhamos em responder a este desafio com um véu de silêncio" (SANTOS e col. 2002, p.37)
\end{abstract}

ABADIA-BARRERO (2002) traz, para esta discussão, um ponto importante: apesar dos problemas no atendimento às pessoas vivendo com HIVIAids no Brasil, por outro lado, é possivel reconhecer situações, em que ter HIV pode ser uma "vantagem". A resposta social à epidemia de HIV/Aids, no Brasil, está associada ao fato de que, inicialmente, a epidemia incidiu sobre setores privilegiados da sociedade - pessoas com poder político e econômico - que se tornaram pioneiras na luta pelos direitos dos pacientes, mediante grande capacidade de organização social e influência política. Isso propiciou que, pessoas soropositivas, pobres, pudessem se beneficiar das redes de suporte assistencial. Em seu estudo, ABADIA-BARRERO (2002) comparou crianças e adolescentes soropositivos, que vivem em uma ONG, com crianças vivendo na rua. Sua pesquisa mostrou que as crianças e adolescentes soropositivos da ONG recebem acompanhamento de saúde e vivem "normalmente", o que lhes garante um leque de opções e a possibilidade de sonharem com um futuro. Por outro lado, crianças que vivem nas ruas, sob o ponto de vista biológico, são mais "saudáveis", mas não têm perspectivas de futuro, com alto risco de ingresso na ilegalidade, exclusão e morte precoce.

Muitos dos pontos, que abordamos, acima, indicam a necessidade de que o cuidado das mulheres vivendo com HIV/Aids envolva, não apenas o aspecto clínico-fisiológico da doença, mas também apoio psicossocial. Além disso, consideramos que o fenômeno estudado é complexo e envolve aspectos Inconscientes. Para melhor compreensāo das questões Inconscientes, que envolvem o desejo, no que concerne à gravidez e maternidade, em mulheres vivendo com HIV/Aids, apresentamos a explicitação de conceitos psicanalíticos sobre feminilidade, maternidade, desejo e gozo. 


\section{Capítulo II - A questão do desejo, como eixo articulador da construção do objeto de investigação}

Para a abordagem da questão do desejo, em sua articulação com a maternidade, foi necessário um percurso, que mostrasse o caminho de construção do conceito de feminilidade, no campo psicanalítico. Para isso, nos valemos, primeiramente, da teoria freudiana, apontando suas contribuiçōes e impasses. Em seguida, traçamos a visão lacaniana do feminino e sua relação com a questão da maternidade, mostrando que essa construção teórica pode ser um instrumento importante para a compreensão desse objeto de investigação.

O diagnóstico de HIV é uma situação que pode levar à re-edição da castração ${ }^{3}$, à medida que remete o sujeito a algo que foi perdido: o estado saudável ${ }^{4}$. Surge, também, a ilusão de que todos os outros, ainda, mantêm esse "corpo saudável" e que só aquele sujeito perdeu tal "bem precioso". Trata-se de uma vivência angustiante, que pode fazer com que, a partir da constatação de que algo "falta", o sujeito possa se dar conta de que precisa buscar algo, que o preencheria. O ser humano tem a possibilidade de fazer escolhas e se responsabilizar por elas, levando seu desejo às últimas conseqüências. Mas, de que desejo estamos falando? Existe uma especificidade do desejo feminino, ou, mesmo, no que se refere a decisōes reprodutivas de mulheres?

A Psicanálise refere o termo desejo no campo de existência do sujeito humano sexuado, ou seja, àquele que vai além do aspecto biológico e se insere no campo das relaçōes entre os humanos. Entretanto, a noção freudiana de desejo difere da noção lacaniana, razão pela qual, apresentamos, a seguir, os passos da construção do conceito de desejo, na teoria freudiana e na lacaniana.

A noção freudiana de desejo não ocupa o mesmo lugar que para Lacan. Para Freud, podemos traduzir o desejo por um plural, ou seja, "desejos", ou desejo, traduzido por um determinado desejo particularizado em um objeto empírico, ou ainda, pela noção de "realização de desejo". Freud (1900) propôs que a interpretação dos sonhos se baseasse no mesmo método da análise, ou seja, na associação livre. O processo interpretativo, relacionado com o processo transferencial, possibilita decompor o sonho em suas partes e evidenciar o desejo do sonhador. Assim, para Freud, o desejo infantil insatisfeito $\theta$ a linguagem pulsional, ali implicita, são como uma fonte eternamente produtora de sonhos (KAUFMANN 1996).

\footnotetext{
${ }^{3}$ Para melhor esclarecimento sobre os conceitos psicanalíticos, vide glossário em anexo.

4 A Organização Mundial de Saúde (OMS) define estado saudável como a situação de perfeito bem-estar físico, mental e social, não apenas a ausência de doença. Trata-se de um conceito complexo, amplo e difícil consenso. Em função disso, podemos tomá-lo como um conceito heurístico que oferece a potencialidade de promover o processo de reflexão sobre a questão. Para melhor esclarecimento sobre essa discussão ver SEGRE \& FERRAZ (1997).
} 
Se, para Freud, o objeto de desejo, representado pelas etapas de desenvolvimento (oral, anal, fálico e genital), é determinante e imprescindível, para Lacan, o objeto desejado no outro não tem tal status. Lacan insiste que o objeto de desejo é a única coisa, que possibilita que o sujeito não se perca na teia dos significantes (sendo carregado pelos inúmeros significantes possíveis de seu desejo) e, assim, o objeto de desejo é a única coisa que realmente individualiza o sujeito.

Por sua vez, Lacan estabeleceu uma trilogia, para explicitar que a dimensão do humano vai além do biológico e está inserido em um sistema de relações, o que, em última instância, diz respeito ao aparelho da Linguagem. A construção teórica lacaniana, que visa explicitar a diferença entre a noção de necessidade, de demanda e de desejo, é fundamental para o processo que instaura o sujeito desejante, na sua relação com o Inconsciente.

Podemos descrever o processo de instauração do sujeito, lastreado pelas dimensões da necessidade, demanda e desejo, de forma simplificada. Quando um bebê pede para comer, ele tem a necessidade de satisfazer sua fome e, se a fome não é satisfeita, ele poderá continuar a pedir, ou seja, a demandar. Se, num primeiro momento, ele é alimentado, trazendo-lhe satisfação de suas necessidades, fica instaurado um traço que será guardado, em sua memória, para caracterizar essa primeira condição de satisfação. Se sua demanda continua insatisfeita, a criança poderá alucinar um objeto que a satisfaça, um objeto de desejo. O seio materno constitui-se, assim, como objeto de desejo primitivo. No processo de constituição do objeto de desejo, 0 ato de alucinar torna-se constitutivo do próprio ato de desejar, fazendo com que o sujeito, na situação de frustração, se remeta à situação de satisfação, anteriormente vivenciada. O seio alucinado é um objeto de desejo, inteiramente criado pelos desejos conjugados da mãe e do filho, sendo muito diferente do seio corporal e do leite nutritivo, que alimenta o bebê. $O$ objeto de desejo é, portanto, uma construção que possibilita a substituição do desejo incestuoso e a satisfação no simples ato de nutrição. Assim, desejar o seio equivale a evitar a via da necessidade e a via do incesto.

O axioma teórico do desejo incestuoso, proposto pela Psicanálise, baseia-se no problema da castração e do Falo ${ }^{5}$. A premissa é que o incesto representa um "mais além", nunca alcançado pelo desejo, ou seja, que um estado de completude e onipotência do ser humano já não poderia ser alcançado, configurando o ser humano como um ser essencialmente falho ou castrado. O incesto, ou a posse completa do corpo da mãe, é uma representação desse estado anterior pleno, postulado pela Psicanálise.

\footnotetext{
${ }^{5}$ Para melhor esclarecimento sobre os conceitos psicanalíticos, vide glossário, em anexo.
} 
O outro termo da trilogia lacaniana, a demanda, diz respeito ao fato de que esta será sempre insatisfeita, pois o sujeito nunca obtém o objeto real que almeja (a satisfação plena) e o desejo é insatisfeito, porque nunca alcança 0 incesto (representado pela posse do corpo total da mãe). Entretanto, através do objeto de desejo, o sujeito pode encontrar certa satisfação parcial, um substituto, que será retomado no processo de construção da fantasia. $O$ desejo é algo que habita todo ser falante ${ }^{6}$ e nos protege de buscar a satisfação absoluta, representada pelo incesto (posse do corpo total da mãe), que é o ponto de ruptura do sujeito ligado a uma satisfação total, que, na teoria lacaniana, é denominado de o gozo do grande Outro.

Da dupla demanda da mãe e do bebê se separa o objeto a, ou seja, o objeto causa de desejo, que é uma produção da díade mãe-bebê, numa conjunção, que assume a forma de amor recíproco mãe-filho. O lactente pede (demanda) o seio e a mãe reconhece essa demanda de seu filho. É no desencontro dessa dupla demanda que se produz um corte, ou seja, se desprende um objeto, com o qual a criança se identifica.

O objeto a, enquanto objeto de desejo, nada tem a ver com uma parte física do corpo, sendo, antes de tudo, uma produção da dupla mãe-bebê e não pertence, nem ao sujeito, nem ao outro. É uma condição imaginária (imagem pregnante) e condição simbólica (da dupla demanda permeada pela Linguagem). Em termos estritos, o objeto a é o furo, o gozo enigmático $e$ inominável, um excesso, que insiste em se fazer presente. Como resultado dessa plasticidade, tal objeto pode assumir todas as imagens visuais, corporais, auditivas $e$ táteis do encontro duplamente desejante (e duplamente insatisfeito), da relação entre a criança e a mãe (entre o sujeito e a mãe, enquanto representante do Outro) (NASIO 1993).

O desejo é definido, então, para Lacan, em sua relação com a ordem biológica (das necessidades) e com a demanda de amor, que é inserida numa estrutura de Linguagem, própria do sujeito falante. 0 desejo ocorre para o homem, porque a satisfação de suas necessidades vitais passa pelo apelo dirigido a um Outro ${ }^{7}, 0$ que, de imediato, altera a satisfação, transformada, assim, pela demanda de amor. O amor é, ao mesmo tempo, um apelo dirigido ao outro, tendo em vista uma satisfação, que não se dará da forma, como é demandada (KAUFMANN 1996).

\footnotetext{
${ }^{6}$ Para a perspectiva psicanalítica lacaniana, o sujeito humano é estruturado em funçāo da Linguagem, levando Lacan a propor que "O Inconsciente é estruturado como uma Linguagem". Assim, a Linguagem $\dot{e}$ condição estruturante tanto para o sujeito, quanto para o desejo inconsciente. Nesse sentido, o ser humano precisa valer-se da fala para tentar lidar com sua perda ou com a sua falta constitutiva.

7 A partir desse ponto do trabalho, passaremos a escrever o conceito de "grande Outro" apenas como "Outro", grafado com maiúscula. A relação do sujeito com seus pares, ou com - "pequeno outro" será grafada com "outro", em letra minúscula. Em francès, o termo "grande Outro" é grafado com a letra "A" em maiúsculo (Autre).
} 
O desejo não é apenas uma representação imaginária da perda imposta pela questão sexual, mas, antes de tudo, uma forma de o sujeito se identificar com a perda, estabelecendo um lugar estrutural de completude, em uma tentativa de reduzir a Falta a um "nada". O que se estabelece, com isto, é que o sujeito desejante, movido pela pulsão, busca, incessantemente, o sonho de completude que sustenta o amor. Isso se evidencia na relação com a mãe, em que o sujeito procura uma mãe completa, ou seja, uma mãe possuidora de um Falo, e se depara com uma mãe castrada. Mas é, justamente, por isso, que se estabelece, na criança, um lugar de Falta, uma incompletude e, assim, instaura-se a função desejante (KAUFMANN 1996).

Para destacar a função do desejo, articulado à hiância entre necessidade e demanda, Lacan aponta o seguinte:

\begin{abstract}
“O que é o desejo? (...) realizar seu desejo coloca-se sempre numa perspectiva de condição absoluta. É na medida em que a demanda está para além e para aquém de si mesma, que, ao se articular com o significante, ela demanda sempre outra coisa, que em toda satisfação da necessidade, ela exige outra coisa, que a satisfação formulada se estende e se enquadra nessa hiância, que o desejo se forma como o que suporta essa metonímia, ou seja, o que quer dizer a demanda para além do que ela formula. É por isso que a questão da realização do desejo se formula necessariamente numa perspectiva de Juizo Final.

Tentem, perguntar-se o que pode querer dizer ter realizado seu desejo - se não é de tê-lo realizado, se podo assim dizer, no final. $\dot{E}$ essa invasão da morte na vida que confere seu dinamismo a toda questão, quando ela tenta formular-se, sobre o tema da realização do desejo. Para ilustrar o que dizemos, se colocarmos a questão do desejo a partir do absolutismo parmenfdico, na medida em que ele anula tudo o que é o ser, diremos-nada é do que não nasceu, e tudo o que existe não vive senão na falta a ser" (LACAN 1997a, p. 353).
\end{abstract}

A articulação dos conceitos de desejo e gozo, com a noção de feminilidade é importante para a construçāo de nosso objeto de estudo. Em função disto, tratamos, agora, de conceituar gozo, na teoria lacaniana, e para tal, precisamos, logo a princípio, situá-lo distintamente da idéia freudiana de "lust" (prazer ou desejo) e do conceito de satisfação.

"O gozo, diz Lacan, é aquilo de que fala o Direito: gozar de uma coisa é poder usa-la até o abuso - abuso que o Direito, justamente, tem a ambição de limitar" (ANDRÉ 1987, p. 211).

Enquanto o Direito define a noção de usufruto, o que reúne as idéias de uso e fruto, como sendo usar um bem até certo ponto, regulando tal gozo à fronteira do útil, para a Psicanálise lacaniana, o gozo se define ao contrário, como aquilo que se opōe ao útil, "como aquilo que não serve para nada". 0 gozo é uma instância negativa, que não se deixa reduzir nem às leis do princípio do prazer ou à necessidade de descarregar a excitação, como situa Freud, nem tampouco, a autoconservação. 
As primeiras elaborações sobre o gozo, na teoria lacaniana, remontam a 1969, em seu texto "Subversão do sujeito e dialética do desejo" (LACAN, 1998b), em que ele pergunta como o sujeito extrai gozo do sexual, e como a análise pode dar acesso a esse gozo sexual. Para Freud, a castração seria um obstáculo, que impede o sujeito de gozar, e ele concebe a castração como um rochedo, ao qual o sujeito não pode ultrapassar. Para Lacan, o gozo sexual é, em si mesmo, uma limitação do gozo, em geral, fazendo uma borda, à medida que depende da dimensão do significante. A dimensão significante $^{8}$ organiza e isola um órgão do corpo, introduzindo, assim, a dimensão sexual, através da própria diferença sexual. $O$ sujeito, ao falar, irremediavelmente, tem que lidar com a dimensão da Falta. Esse gozo suporta o "eu sou", mas não é, inteiramente, simbolizado pela dimensão do "eu penso", ou seja, há uma dimensāo que subsiste aos questionamentos do ser: "quem sou eu?"

Esse gozo do ser, ou gozo do Outro, não é equivalente a desejo algum do sujeito, e resiste a toda apreensão e a todo raciocínio significante. Temos acesso, apenas, ao resto, como resultante operacional da incidência do gozo, algo que pode ser tomado, como da ordem do sofrimento. Por outro lado, o gozo sexual tem o efeito de nos interditar. Não ingressamos na ordem do gozo sexual com nosso ser, mas pelo significante. Só há um significante da sexuação (o falo) e, portanto, no nível do discurso inconsciente, não há relação formulável (não há proporção sexual) entre dois sexos. Para o Inconsciente, não há possibilidade de se representar um Outro, sexuado enquanto Mulher, ou seja, a Mulher não recebe fundamento para seu ser, o que leva Lacan a formular o aforismo "a Mulher não existe".

\begin{abstract}
"Este interdito deve ser entendido no equívoco da palavra: inter-dito. O gozo do ser - especialmente do ser feminino, do Outro sexuado como tal - não pode ser dito, é rejeitado naquilo que subsiste entre os ditos, a título de indizivel, de fora-da-linguagem: "Isso ao que é preciso ater-se, $\theta$ que o gozo é proibido a quem fala como tal, ou ainda, que ele so pode ser dito entre as linhas para quem quer que esteja sujeito à Lei, pois que a Lei se funda sobre essa própria interdição"m (ANDRÉ 1987, p. 214).
\end{abstract}

\title{
2.1 - A construção do feminino, no âmbito psicanalítico
}

Para compreensão do conceito de feminino, na teoria freudiana, podemos traçar um percurso teórico, que vai da sexualidade, como fator fundamental para as construçōes teóricas freudianas, passando pela explicitação da função fálica, na teoria edipica, até a problematização do Édipo feminino.

Freud compreendia a sexualidade, como conceito fundamental de sua teoria e, embora tivesse mantido a hipótese do embasamento orgânico, afastou-se do conceito de instinto sexual, e propôs a idéia da pulsão, como

\footnotetext{
${ }^{8}$ Para melhor esclarecimento sobre os conceitos psicanaliticos, vide glossário, em anexo.
} 
elaboração especifica do humano para lidar com sua sexualidade, fazendo uma afirmação, aparentemente, simples: os impulsos (Trieb) oriundos do corpo almejam a satisfação (FREUD 1996a). O conceito de pulsão é, portanto, o eixo primordial da teoria freudiana da sexualidade, e pode ser definido como um conceito-limite entre o psíquico e o somático. Em "A pulsão e os seus destinos" (1996e), Freud descreve a pulsão como uma força constante, originada do organismo, cuja finalidade é a satisfação, ou supressão de estimulação da sua fonte (a zona erógena). A pulsão tenta alcançar a satisfação, por meio de um objeto, mas que, diferentemente do instinto, que possui um objeto específico de satisfação, na pulsão, o objeto pode ser substituído indefinidamente.

No texto "Além do princípio do prazer", Freud (1996f) valeu-se do conceito de pulsão e o correlacionou com a questão da repetição. Como resultante dessa articulação, o conceito de pulsão foi reformulado, passando a ser uma tendência do organismo vivo à reconstrução de um estado anterior (estado inanimado). Nesse sentido, Freud deduz que a função do principio do prazer é manter, o mais baixo possivel, a excitação do sistema psíquico, numa entropia que, em última análise, aponta para um retorno ao mundo inanimado ou inorgânico. Se, o principio do prazer alia-se à pulsão de morte, para manter seu estado "estático", podemos perceber que a pulsão sexual atua de forma a "excitar esse sistema" e, portanto, alia-se ao princípio de vida, atuando para "além do princípio do prazer".

PRATES (2001) ressalta que, a leitura desse texto de Freud permite interpretar que a ausência de excitação, almejada pelo princípio do prazer, na manutenção de um estado estático, pode se valer da pulsão de morte. Como conseqüência, a vida é uma construção proveniente da insatisfação, ou de um adiamento da satisfação para um mais além. A importância desse pressuposto té́rico, sobre a pulsão, reside no fato de que a partir disto, podemos tomar o conceito de desejo, como aquilo que leva o sujeito à satisfação, à descarga da pulsão sexual. Entretanto, Freud ressaltou que a satisfação da pulsão só pode ocorrer de forma parcial, através de um objeto, e por meio do desejo sexual.

No texto "A organização genital infantil" (1996g) Freud afirmou que o complexo de castração só acontece, quando a representação de uma perda se une ao falo. PRATES (2001) lembra que perdas infantis (como o desmame, as fezes), associadas aos danos narcísicos, são ressignificados dessa forma. $O$ processo de equivalência simbólica, entre pênis e seio, fezes, clitóris e bebê, pode ser compreendido, se pensarmos que a criança associa sentido de "falta de falo" a todas as experiências de insatisfação.

A teoria libidinal, em Freud, fala do desenvolvimento psicofisiológico no sujeito humano, e propōe uma diferenciação do processo de formação psíquica do homem e da mulher. Para Freud, o caráter biológico da sexualidade é determinante, mas, como cada sujeito vai lidar com seu "destino anatômico" constitui uma revelação da sua dinâmica desejante. Os 
conceitos de "masculino" e de "feminino" são eminentemente ligados ao aspecto psicológico, e fundamentados na noção de bissexualidade humana, ou seja, a "bipolaridade" se refere à bipolaridade do desejo e, não, à diferença entre os sexos, em si mesma. Assim, todo ser humano tem, portanto, que se haver com seu desejo dirigido, tanto à figura paterna, quanto à figura materna.

No texto "As teorias Sexuais infantis", Freud (1996c) refere que meninos e meninas celebram a universalidade do pênis, resultando o medo da castração, por parte do menino, e a inveja do pênis, por parte da menina. No texto "A organização genital infantil" Freud (1996g) aponta, não a universalidade do pênis, mas o primado do Falo, criando uma importante nuance. $O$ mecanismo do complexo de castração do menino se instaura, quando este compreende o sexo feminino como falta de pênis, enquanto representante do falo. Mas, nesse texto, ele constatou que faltava examinar, melhor, o processo na menina. Freud havia percebido que há, tanto para homens, como para mulheres, uma tarefa: lidar com a questão do falo, da castração e da morte.

\begin{abstract}
"Ao mesmo tempo, a característica principal dessa 'organização genital infantil' é sua diferença da organização genital final do adulto. Ela consiste no fato de, para ambos os sexos, entrar em consideração apenas um órgão genital, ou seja, o masculino. O que está presente, portanto, não é uma primazia dos órgãos genitais, mas uma primazia do falo" (FREUD 1996g, p.158).
\end{abstract}

Em seu artigo, de 1925, "Algumas considerações Psíquicas da Diferença anatômica entre os sexos", Freud (1996h) formula, explicitamente, o Édipo feminino, como a transferência ${ }^{9}$ de uma relação inicial da mãe ao pai, sendo que o pai tem função de metáfora. Há uma clivagem entre o anatômico e o psíquico, e o que é perceptível, anatomicamente, não poderá ser inscrito, como tal, no psíquico. $O$ que se inscreve no psíquico é a consequêencia dessa diferença sexual, ou seja, a castração. Assim, meninos e meninas vão ter uma inscrição diferenciada no processo de castração (dissimetria essencial da funçāo da castração) e, por isso, instauram-se modos diferentes de pensar "masculino e feminino". Para o menino, o complexo de Édipo é uma formação primária: no primeiro estágio, o menino conserva seu primeiro objeto de apego (a mãe), e o complexo de castração encerra o complexo de Édipo. Para a menina, o complexo de Édipo é secundário: ela tem que renunciar ao amor da mãe, como primeiro objeto, e substituí-lo pelo pai.

A resultante feminina, do complexo de castração, instaura a mulher em uma posição muito diversa do que acontece no menino. A constatação da diferença anatômica, entre os sexos, instaura na mulher a inveja do pênis e é, a partir da renúncia ao pênis, substituindo-o pelo desejo de ter um filho, que a menina resolve seu Complexo de Édipo. Ao renunciar ao pênis

9 Nesse momento de seu estudo, o conceito de transferéncia aqui citado se refere especificamente a um "deslocamento", uma transposiçāo. 
(enquanto representante do objeto de desejo fálico perdido), a mulher busca - pai, rivaliza com a mãe, identificando-se, porém, com sua capacidade procriativa: ela torna-se mulher, ao tornar-se mãe, segundo Freud.

"(...) a libido da menina desliza para uma nova posição ao longo da linha - não há outra maneira de exprimi-lo - da equação 'pêniscriança'. Ela abandona seu desejo de um pénis e coloca em seu lugar o desejo de um filho; com esse fim em vista, toma o pai como objeto de amor. A mãe se torna o objeto de seu ciúme. A menina transformou-se em uma pequena mulher" (FREUD 1996h, p. 284).

"O desejo que a filha tem do pai não passa, sem dúvida, originalmente, do desejo de possuir um falo, o falo que the foi recusado pela mãe e que ela agora espera receber do pai. Todavia, a situação só se estabelece realmente quando o desejo do pénis é substituido pelo desejo de ter um filho, tomando-se este, segundo uma velha equivaléncia simbólica, o substituto do pênis" (FREUD 1996], p.128).

Na visão freudiana, a questão da instauração do desejo, próprio do feminino, não pode deixar de passar pela questão da reprodução e possibilidade de produção de um "filho-falo", que seria, então, uma tentativa de restauração narcísica possivel para uma mulher. Entretanto, ficou evidente, para Freud, após um certo percurso, como analista, que a sexualidade feminina não é idêntica à sexualidade masculina, assim como o percurso do chamado Complexo de Édipo é, eminentemente, diverso para cada um dos sexos.

"Sabemos menos acerca da vida sexual de meninas do que de meninos. Mas não é preciso envergonharmo-nos dessa distinção; afinal de contas, a vida sexual das mulheres adultas é um 'continente negro' para a psicologia. Mas aprendemos que as meninas sentem profundamente falta de um órgão sexual que seja igual em valor ao masculino; elas se consideram por causa disso, inferiores, $\theta$ essa 'inveja do pénis' é a origem de todo um grande número de reaçöes femininas características" (FREUD 19961, p. 205).

Embora Freud tenha se expressado dessa forma, a teoria freudiana sofreu algumas críticas, afirmando que ele havia construído suas teorias, a partir de preconceitos típicos do momento histórico em que vivia, sem verificar a realidade empírica de suas afirmações. Essas críticas decorrem das descobertas da sexologia, a respeito da sexualidade humana, especialmente, a sexualidade feminina. PRATES (2001) aponta que, de forma geral, as críticas às afirmações de Freud eram obsoletas e destituídas de fundamento biológico. As feministas criticaram a Psicanálise, por colocar - gozo clitoriano como um sintoma histérico, reivindicando o direito ao prazer, como um avanço contra o patriarcado, que visava cercear a sexualidade feminina.

Outra crítica à teoria freudiana é a que não aceita a universalização do falo, como regulador da norma sexual na constituição da cultura. Após os estudos de Lévi-Strauss, sobre a organização da forma de viver a 
sexualidade, em diversas culturas, que constatou a questão da proibição do incesto (e instauração do Complexo de Édipo), tornou-se uma perspectiva mais aceita, embora os críticos não deixem de questionar, tanto o estruturalismo de Lévi-Strauss, como a teoria freudiana.

Há, ainda, a possibilidade de abordar a questão do feminino, enfatizando a questão da sexualidade feminina, como algo identificado à "natureza", ou como um "fardo simbólico". Assim, Paglia, em seu livro Personas Sexuais (apud PRATES 2001), comenta que a civilização e a cultura são construçōes, eminentemente, masculinas, que tentam se afastar da "natureza-mãe", em repugnância àquilo que as mulheres representariam, ou seja, o pecado original, ou a mancha das imperfeiçōes humanas.

Tais críticas podem ser tomadas em duas vertentes:

1- Críticas à Psicanálise, por adotar uma suposta posição "essencialista".

2- Críticas à Psicanálise, por deixar de levar, em consideração, a contextualização sócio-cultural.

As críticas à teoria freudiana, embora interessantes, parecem abordar a questão do feminino, priorizando a idéia de que haveria uma "equivalência valorativa" do sexo feminino, em relação ao masculino. A teoria freudiana não oferece, em si, todos os subsídios, necessários para abordar a questão da feminilidade (Freud, ele mesmo, o admitiu) e não restou a Freud outra alternativa, a não ser pensar o final de uma análise, para as mulheres, como uma constatação da impossibilidade de obtenção do pênis desejado, como uma "rocha". PRATES (2001) procura interpretar a posição freudiana, perante a sexualidade feminina, enfatizando que Freud teve dificuldades em avançar, perante o enigma da feminilidade, e o sexo feminino seria a própria representação do impossivel de significar, como um resto inassimilável. Assim, o "rochedo da castração", em Freud, é o termo cunhado para representar esse limite, intrínseco, na análise freudiana.

Vemos, então, que a questão da feminilidade torna-se um paradigma, para teorizar, não apenas a respeito das mulheres, mas também a prática da clínica analítica.

"A escolha por questionar especificamente a posição da mulher remete ao fato de que, na polémica a respeito da sexualidade humana, a mulher aparece freqüentemente como o que aponta para algo que escapa e a que se tem dificuldade de nomear ou sintetizar. A mulher parece revelar o desencontro humano com a natureza, fazendo-o aparecer mais nítido, mais explícito, e talvez por isso mesmo mais incómodo a camuflado. Por outro lado, suas manifestaçōes corpóreas (gravidez, menstruação, etc.) apontam para um "resto de natureza" que não se deixa apagar" (PRATES 2001, p. 23).

O problema do complexo de Édipo feminino permanece uma questão, na teoria freudiana. De fato, o que se observa, nas mulheres, é que o pai 
parece nunca substituir completamente a mãe, e, portanto, a metáfora paterna não parece ser definitiva. Na etapa pré-edípica, não há o que distinga a relação da menina e do menino com a mãe, inclusive, no que se refere à fantasia de dar um filho para a mãe (PRATES 2001; ANDRÉ 1987). Há, sempre, um retorno da relação com a mãe e, por isso, talvez, não se instaure um significado novo, ou seja, uma metáfora. O que parece haver é da ordem de uma metonímia. A ligação do "pênis invejado", com o filho, também parece da ordem da metonímia, pois a menina parece, assim, não ter renunciado absolutamente ao pênis, buscando um equivalente a ele.

\begin{abstract}
"Que a criança constitua, à falta de pênis, o signo da identidade feminina é sempre apenas uma esperança, até mesmo uma denegação: a clínica nos ensina, assim, que a maternidade, sob esse ponto de vista, é freqüentemente acompanhada por uma depressão, ou por um contentamento de fachada, que é muito revelador" (André 1987, p. 179).
\end{abstract}

Tanto no aspecto pré-edipiano, quanto no edipiano, propriamente dito, há uma série de mudanças, que funcionam como desdobramentos, e não como simples substituiçōes, na constituição do Édipo feminino. Deste modo, os aspectos pré-edipianos nāo são eliminados.

"O destino da menina aparece assim, como o de uma metáfora impossivel ou de uma luta permanente para se elevar do registro da metonímia para o da metáfora" (André 1987, p. 187).

ANDRÉ propõe duas questões: "o que justifica o abandono da mãe, que era, no entanto, tão exclusivamente amada? E o que faz com que ela mereça o verdadeiro ódio votado pela filha, ao mesmo tempo em que conserva seu amor?" (ANDRÉ 1987, p.183). Quanto a isto, Freud responde que a ambivalência da relação com a mãe (relação de amor e ódio com a mãe) justifica essa passagem: nesse aspecto, o menino pode liquidar seu ódio, voltando-o para o pai, e guardando parte de seu amor para com a mãe. A figura materna se apresenta, ao mesmo tempo, como objeto de amor (um Outro) e como um pólo de identificação (um outro), tendo, portanto, uma "dupla natureza". Enquanto o menino pode cindir esse estatuto, pela entrada em cena do pai, passando a identificação para o lado paterno, e a mãe, permanecendo como objeto de amor, a menina tem que lidar com a questão, de que a identificação com a mãe parece ser a condição para não mais amála. O que se observa é que, isso não acontece, pois ela não deixa de amar a mãe, mas, o paradoxo, dessa relação, sempre retorna.

\title{
2.2 - O processo de "tornar-se mulher" e o Édipo feminino
}

A perspectiva lacaniana esclarece que a constituição da feminilidade se reporta a um estágio "pré-edipiano", que se caracteriza pela relação primária com a mãe, enquanto representante do grande Outro, o Outro materno, ainda não desdobrado ou dividido pelo lugar da Lei. Haveria, então, na menina, uma persistência da relação com o Outro, que não se depõe 
perante a metáfora paterna. Disso, conclui-se que o pai não se impõe, verdadeiramente, como metáfora, no destino feminino, em outras palavras, a filha não é, totalmente, assujeitada à função paterna.

\begin{abstract}
"Se a função do pai consiste em introduzir o sujeito na lei do falo, e esse significante do falo é insuficiente, por definição, para significar aquilo que seria a feminilidade propriamente dita, o resultado é que a significação induzida pela metáfora paterna fica sempre incompleta, insuficiente para atribuir a um sujeito seu lugar de mulher" (ANDRÉ 1987, p.181).
\end{abstract}

A identificação fálica sublinha a exclusão do feminino da representação. Se a menina se sujeita à lei fálica, instaurada pela função paterna, o faz de maneira ressentida, e, como conseqüência, essa lei não vai operar por inteiro, fazendo com que a menina se situe, ao mesmo tempo, na lei e, em parte, fora-de-lei.

A mudança da primeira, para a segunda fase do Édipo feminino, não é, somente, uma mudança de objeto de amor (da mãe para o pai), mas também, uma mudança de sexo, o que aponta duas vertentes: mudança de identificação sexuada e mudança do tipo de gozo, que o sujeito obtém do sexo (substituir o clitóris pela vagina), comenta Freud. Mas, o que se observa, na prática, é que o gozo clitoriano não é abandonado, e não é substituído pelo gozo vaginal. ANDRÉ (1987) ressalta que o gozo vaginal se acrescenta ao clitoridiano, apontando, mais uma vez, para um processo metonímico, não para uma metáfora.

Vemos, entāo, que a menina se volta para o pai, não em função de atração pelo homem, mas por ódio da mãe. O que permanece "pendente" para a menina é que, embora, posteriormente, tenha que se deparar com a fantasia de sedução paterna, ainda persiste uma questão, referente a uma "sedução primária pela mãe" (ANDRÉ 1987).

Se a relação com a figura materna tem uma função estruturante, tanto para a menina, quanto para o menino, o ponto de partida é o desejo da mãe. A criança (seja menino ou menina) ocupa, primeiramente, uma posição que tampona a falta, tornando a mãe um ser completo. Embora se imagine que, quando a criança nasce, pode-se dizer que "ainda não foi posta no mundo enquanto sujeito", não há uma suposta fusão paradisíaca, pois, já neste primeiro tempo, a relação mãe-criança é repleta de conflitos e discordâncias. Ocorrem desencontros, entre o lugar e a função que a criança ocupava, em sua fantasia, durante a gravidez, e a "criança imaginária" dá lugar à "criança real". O que se observa, nesse primeiro momento, é um intenso "estranhamento", perante uma criança que, ao nascer, pode ser tomada como um objeto assustador e inatingível. Nesse sentido, a criança ocupa o lugar de um objeto "real demais", em desacordo com o objeto imaginado e idealizado, anteriormente. Tal situação pode desencadear, em maior ou em menor grau, as depressões pós-parto e, em casos extremos, delírios pósparto, ou ainda, total "desinteresse" pelo recém-nascido. 
SZEJER (1999) aponta que algumas intervenções psicológicas visam fazer com que as pacientes "abandonem" suas concepçōes imaginárias, em relação ao filho, e que esse tipo de intervenção mostra-se, não apenas inadequado, mas, também, impossivel. Nesse sentido, as construções imaginárias não devem ser tomadas como algo inadequado, mas, sim, elaborações factíveis e necessárias, como uma tentativa de fazer frente ao real.

"(..) Alguns psicanalistas trabalham em neonatologia pensando ser mais urgente ajudar as mães a fazer o luto de sua 'criança imaginária', sem o qual a separação em relação ao filho real ser-lhe-ia insuportável" (SZEJER 1999, p. 59).

\begin{abstract}
"Quanto a essa idéia de que a mãe deva fazer o luto de uma criança imaginária, qual o sentido disso? Não se poderia dizer, ao contrário, que a criança imaginária nunca morre? É dela que um pai ainda poderá dizer, quando estiver desolado com o fato de que sua progénie agora adulta esteja menos próxima de suas esperanças do que ele sonhara: Sabe, mesmo quando vocé tiver 60 anos, continuará sendo o meu bebé!" (SZEJER 1999p. 60).
\end{abstract}

A relação mãe-criança é, inicialmente, triangular: liga a mãe como Outro todo poderoso, a criança, enquanto objeto real, entregue ao gozo materno e, no oposto dessa posição real, a criança imaginária, onde se deposita o narcisismo materno (que tampona a falta materna). A figura, abaixo, ilustra a relação da figura materna e as representações da criança.

Figura 1 - Diagrama ilustrativo da relação entre a figura materna e as representações da criança

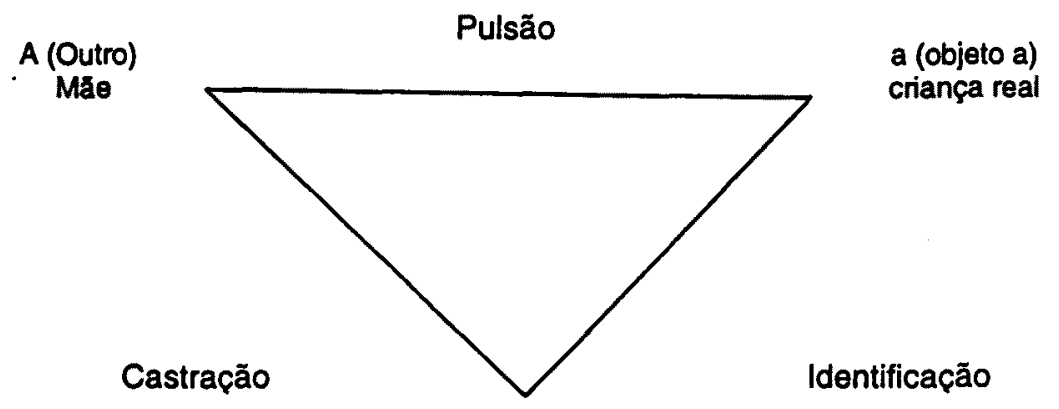

Criança imaginária

(falo imaginário)

Fonte: ANDRÉ 1987, p. 195

Quanto ao pólo imaginário, podemos tratar de alguns importantes aspectos. Se a criança tenta se identificar com a criança imaginária (falo), correspondendo à completude materna, só pode situar sua mãe como faltosa e, por isso, encarrega-se de preencher essa falta. Como 
conseqüência lógica disto, temos o rompimento do Outro materno, como todo poderoso, e, por isso, o pai pode se inscrever, com a função simbólica de interdição fálica. O pai possibilita, assim, que o falo imaginário da relação mãe-criança possa receber uma mediação simbólica. Para a menina, tal processo, embora abra uma possibilidade de saída da dependência materna, sublinha que o registro fálico não situa a constituição da sua feminilidade, levando-a, assim, a uma profunda insatisfação.

Na relação pré-edipiana, da menina com sua mãe, entre a mãe e a criança real (entre A e a, na figura acima) ocorre o registro pulsional, ou seja, a luta entre o sujeito e o Outro, em torno do objeto do gozo. Entre o registro da criança real e a criança imaginária desenrola-se 0 registro das identificações (nesse registro, situamos o exemplo das brincadeiras de bonecas, que servem, tanto como fixação da imagem da mãe, quanto da própria criança, $e$ indicam toda a ambivalência presente na relação especular). Entre a mãe e a criança imaginária, dá-se a problemática da castração (conforme a castração materna seja assumida).

A separação entre o menino e sua mãe, pela entrada do pai, faz com que ele encontre uma saída da identificação ao falo imaginário, referente ao desejo materno. O menino encontra, no pai, um apoio para sua identificação viril, que corresponde ao seu sexo e, dessa forma, a entrada na castração dá, ao menino, acesso à sua identificação masculina. Para a menina, tal processo de separação é mais difícil e complexo, pois, a partir de Lacan, sabemos que a identificação imaginária só se fixa, como semelhança, se o sujeito puder se apoiar num traço simbólico, um "traço unário", como um significante mínimo, que o sujeito apanha do Outro, para referenciar sua identidade. Na menina, há um problema, pois a mãe não pode oferecer à filha um traço significante da identidade feminina (não existe) e, por isso, ela tem que se confrontar com essa falta radical no Outro, havendo, portanto, um reforço da castração feminina, constituindo a falta de uma palavraausência, de uma palavra-furo.

A mãe remete a filha a um marco, que pode lhe significar, mas que não a detém. O que resulta daí, é que a vida sexual feminina se centra na demanda de amor, ou seja, na demanda de se fazer dar, pelo Outro, aquilo que não se tem. A falta da mãe é dupla: falta do significante de uma identidade feminina e falta do falo.

A questão do Édipo, na mulher, mostra-se significativamente complexa, o que levou Freud a apontar três possibilidades de resolução do complexo de Édipo feminino:

1. A via neurótica (inibição sexual);

A primeira vertente, a via da neurose, é caracterizada pelo abandono da sexualidade fálica, ou seja, da masturbação clitoridiana. 0 amor da menina por sua mãe, na fase pré-edipiana, é um amor pela mãe fálica, um Outro sem falha, não barrado. A castração materna aponta para o 
desapontamento da menina, para com sua mãe, que, segundo Freud, faz com que a menina assuma o papel da mãe destronada, identificando-se com ela. Renunciando à masturbação clitoridiana, a menina renuncia, em parte, da sua sexualidade ativa, e o aspecto passivo assumido, a impele a um movimento, em direção ao pai. Mas, nesse ponto, a teoria freudiana comporta uma dificuldade, na medida em que aponta a neurose, como uma via para a feminilidade, visto que, para Freud, a verdadeira posição feminina se estabelece, posteriormente, quando a menina renuncia ao desejo pelo pênis e o substitui pelo desejo pelo filho (filho= pênis).

2. A via caricatural (complexo de masculinidade):

O complexo de masculinidade, na menina, desenvolve-se em duas vertentes: a esperança de obter, um dia, o pênis, que a faria semeihante ao homem, e a denegação, em uma recusa a reconhecer sua falta (obstinação de que possui um pênis e comportamento masculinizado). A menina acentua a atividade masturbatória fálica, e se refugia em uma identificação à mãe fálica, ou ao pai. Essa atitude influencia a escolha de objeto da menina, em direção à homossexualidade manifesta, ou à masculinidade infantil.

3. A via da feminilidade. (para Freud, equivale à maternidade)

Freud aponta que o "enigma da mulher" se relaciona com a bissexualidade da vida feminina. Há uma oscilação entre as duas fases do Édipo, de dois objetos de amor e, portanto, de duas possibilidades identificatórias. A escolha amorosa feminina, a escolha do homem, vai se submeter a essa cisão, entre o modelo paterno (escolha objetal) e o modelo narcísico (escolha narcisica), o que é, ainda, mais conflituoso, se levarmos em conta que há uma oscilação das posiçōes de "masculinidadefeminilidade".

ANDRÉ (1987) assinala que a teoria freudiana enfrenta os seguintes problemas:

- Para Freud, seria pela via expressada pelo filho-boneca, que o desejo do pênis se tornaria o desejo pelo filho do pai, ou seja, a inveja do pênis levaria a menina à feminilidade. Mas, na fase pré-edipiana, a menina brincava de bonecas com duas finalidades: a serviço de uma substituição da passividade, pela atividade (em uma luta em relação ao Outro materno) e por uma identificação com a mãe, repetindo, com a boneca, 0 que sua mãe faria com ela. Vemos, portanto, que não há nenhuma implicação da figura paterna nas brincadeiras de boneca, pois estas constituem a expressão da feminilidade, e o pai encontra-se fora da questão.

- Na teoria freudiana, o tornar-se mulher confunde-se com tornar-se mãe. Freud acaba por atribuir, ao filho, o papel significante da identidade feminina, na falta de outro "sinal" da feminilidade. 
- A questão do complexo de masculinidade não se relaciona com a inveja do pênis, mas, sim, com uma decepção com a figura paterna ${ }^{10}$.

- Se Freud considera a posição, diante do pai, como o desfecho da situação edípica, a clinica psicanalítica aponta que, na prática, tal situação é sempre precária, pois, mesmo que a mulher estabeleça relaçōes substitutivas com outros homens, passa da fixação de amor do pai para outros homens, a relação primitiva com a mãe se faz, insistentemente, presente.

- O tornar-se mulher é um impasse, que é retomado na relação amorosa, pois, tornar-se mãe denota um predomínio da relação mãe-filho perante a relação mulher-marido. A problemática feminina da maternidade, como realização simbólica do desejo do pênis, deixa espaço para especulaçōes e sombras, que desembocam, irremediavelmente, nas questões da inveja do pênis e da demanda de amor.

A questão do feminino, para Freud, não deixou de ter repercussōes, pois, ele mesmo parece ter dificuldades em abandonar a sua própria idealização, a respeito do que ele supõe que deveria ser uma mulher: ele acreditava que uma mulher só se torna mulher quando abandona, completamente, a sexualidade fálica, tornando-se "toda mulher".

"O fato de que as mulheres possuam dois órgãos genitais distintos parece para Freud altamente problemático. Já ressaltamos a fragilidade da idéia segundo a qual um desses órgãos - a vaginadeveria substituir o outro - o clitóris - mesmo que, na elaboração de Freud, a vagina permaneça não reconhecida enquanto sexo. Por que deveriam as mulheres, de alguma maneira, sacrificar o clitóris à vagina?" (ANDRE 1987, p. 203).

Se a feminilidade é um enigma, não poderia Freud estar inclinado a manter seu estatuto de obscuridade? Em vários textos, Freud apontava a sexualidade feminina, como misteriosa, irracional e, até, perigosa. Não seria da ordem do insuportável, para o menino, ter que se deparar com o Real da castração, ao lidar com o sexo feminino? Podemos, então, situar a leitura freudiana como uma abordagem possível, para lidar com o Real que a mulher encarna? A teoria da castração e o primado do falo podem funcionar, ao mesmo tempo, como máscara e como revelação do mistério, que constitui a feminilidade (PRATES 2001).

O processo, que transforma uma menina em uma mulher, aponta para uma situação de grande complexidade, que pode, ou não, levá-la a tornar-se mãe, mas que, sem dúvida, a questão da maternidade é um

\footnotetext{
10 o artigo de Homey, de 1922 (apud ANDRE 1987), mostrou que o complexo de masculinidade 6 uma emergéncia de uma relaçăo primitiva com a măe, no próprio seio da relaçăo com o pal, sendo que a filha experimenta um sentimento de decepçăo relacionado ao pai e ciúmes relacionado à măe. A decepçāo pode levar a uma renúncia da reivindicação amorosa dirigida ao pai e também a uma renúncia de seu desejo de um filho. A inveja do pénis nāo é portanto a "causa" do complexo de masculinidade, mas sim, um desapontamento em relaçăo ao pai enquanto objeto de amor. Quando a demanda de amor é desapontada, a menina pode se identificar com o pai, adotando suas características sem que a menina chegue a uma escolha de objeto homossexual propriamente dito. A identificação ao pai não deve ser confundida com o desejo de ser um homem, mas sim o desejo de desempenhar o papel do pai.
} 
aspecto que a menina tem que situar, para poder posicionar-se perante a construção de sua feminilidade, bem como o exercício de sua sexualidade.

\section{3 - O feminino, na teoria lacaniana}

A lógica da elaboração freudiana sobre a feminilidade parece conduzir a um impasse: a relação com a mãe, na fase pré-edipiana, é um aspecto pendente e, ainda que ela tenha ingressado na fase edipiana, propriamente dita, o retorno é iminente. Além disso, o "rochedo da castração", proposto por Freud, constitui uma dificuldade para teorização do feminino.

Para avançar na questão do feminino, Lacan valeu-se de outras áreas de conhecimento e construiu uma teoria que, embora traga novas propostas, é, em essência, fiel à teoria freudiana. Lacan enfatizou que o registro simbólico (ou seja, a Linguagem) é o que caracteriza a dimensão humana, em suas especificidades e particularidades. Assim, Lacan se valeu das descobertas lingüísticas, de Saussure, e inverteu 0 algoritmo saussuriano, para apontar a primazia do significante ${ }^{11}$ sobre o significado. Para Saussure, o signo lingüístico é a articulação arbitrária de um determinado conceito (significado) e uma imagem acústica (significante), enquanto, para Lacan, há uma inversão, que aponta para uma resistência à significaçāo, ou seja, o inconsciente estruturado, como linguagem, mostra que o funcionamento do inconsciente implica essa "barra" entre a noção de significante e significado. Há, portanto, a partir da noção do inconsciente, um impossivel de se significar.

Seguindo Freud (1996b), no texto "A interpretação dos sonhos", que propôs o sonho como um processo de formação lógica, que obedece aos princípios da condensação e do deslocamento, Lacan fez uma releitura desses conceitos, a partir da Lingüística, apontando que esses dois princípios do funcionamento inconsciente são equiparáveis às figuras de linguagem: a metáfora se equipara à condensação, e a metonímia, ao deslocamento.

O conceito de Outro (A) é chamado, por Lacan, de "lugar do tesouro dos significantes", sendo um lugar simbólico, o lugar do código. Cabe ao sujeito a tarefa de se constituir, a partir dessa relação com o Outro, da Linguagem, mas PRATES (2001) relembra que essa relação primordial indica uma interdição primitiva universal do gozo, que coloca o sujeito perante uma inadequação do objeto da necessidade instintiva, perante a questão da lei. Freud realiza, em seu texto "Totem e tabu" (1996d), uma tentativa de explicação, ainda que mítica, para a construção da lei de interdição do incesto e o estabelecimento da lei, o que, em última análise,

\footnotetext{
${ }^{11}$ Para melhor esclarecimento sobre os conceitos psicanalíticos, vide glossário.
} 
aponta para um rompimento fundamental com a natureza. Mas, para que haja lei, há que haver um legislador, que pode ser tomado como esse Outro. Lacan evidencia que esse legislador não é nada além de um impostor, visto que esse Outro do Outro não existe.

Para elaborar um conceito, que forneça o estatuto lógico para o processo de instauração da lei e da interdição civilizatória, no humano, Lacan se valeu do estruturalismo $e$, através dessa fonte, valendo-se da linguagem, como pressuposto, articulou, teoricamente, o pai morto da horda primitiva ao conceito de Nome-do-pai. Lacan ressaltou que, a partir dessa articulação lógica, a impossibilidade de acesso direto ao objeto não se dá, propriamente, em função da interdição, mas de uma proibição, logicamente, anterior, que aponta para perda da condição humana natural, à medida que o homem tornou-se um ser falante.

Passemos, agora, ao relato sintético dos passos lógicos da constituição do sujeito do inconsciente, pois estes são um testemunho de como um sujeito lida com a falta estrutural (LACAN 1999, p. 149).

No primeiro tempo do Édipo, a criança encontra-se alienada na posição de objeto de desejo do Outro absoluto, representado pela figura materna. Trata-se de um tempo mítico inaugural do processo de simbolização, correspondente à "função materna".

No tempo seguinte, o segundo, o sujeito se depara com a falta do Outro, através das falhas de discurso que ele encarna, o que o leva a se colocar, perante o enigma do desejo do adulto. A falta do Outro (Lacan), ou, a privação materna (Freud), são, posteriormente, significadas pela castração, constituindo o suporte da fantasia inconsciente, que promove a relação do sujeito com o objeto.

\begin{abstract}
"A mãe introduz através da escansão do apelo feito pela criança, o para presença-auséncia que é elemento fundamental para a constituição da ordem simbólica. Quando a mãe deixa de responder a esse apelo, possibilita que o objeto se torne simbolico" (PRATES 2001, p. 70).
\end{abstract}

O sentido da castração materna toma um estatuto diferenciado, em Freud e Lacan, à medida que, embora Freud tenha dado grande importância à questão para a constituição do sujeito, ele o faz, ressaltando o aspecto anatômico, enquanto Lacan despendeu um grande esforço, para demonstrar, logicamente, que não é propriamente a visão dos genitais femininos que importa na dialética da castração, mas sim, a falta no Outro (A), que retroage sobre o sujeito, em registros e formas diferentes, em função da estrutura em questão (PRATES 2001). Para Lacan, o falo é o lugar privilegiado de ser aquilo que pode faltar, ou que é suposto faltar ao Outro, encarnado pela mãe. O fato de a mãe, enquanto mulher, ser privada de falo, faz com que ela coloque a criança (seu filho) nesse lugar simbólico. 
A primeira identificação da criança é, assim, com o falo, enquanto suposto objeto de desejo da mãe.

No terceiro tempo do Édipo, ocorre o processo de simbolização, propriamente dito, articulado com a função paterna. A função paterna tem a função de presentificar, simbolicamente, o objeto faltoso, diz Lacan. $O$ pai, enquanto representante da autoridade da lei, traz à tona a ameaça da castração, que significa, falicamente, a privação materna. O sujeito vê-se barrado (\$) e, a partir daí, o falo se constitui como significante, enquanto parte faltante à imagem desejada.

\begin{abstract}
"É este o sentido da castração e da metáfora paterna: o pai cumpre a função de subjetivar a instauração da lei, pondo o inconsciente a funcionar. O complexo de castração, ao contrário do Édipo, como afirma Lacan, näo é mito, mas estrutura. O falo simbólico, como produto desta operação de metáfora, regula e contoma o gozo impossivel, unindo o desejo à lei" (PRATES 2001, p. 71-72).
\end{abstract}

Lacan toma o Complexo de Édipo, proposto por Freud, como referência estruturante, para a constituição do sujeito, em relação ao seu posicionamento perante a questão da falta, para além da questão do mito freudiano. Freud descobriu o funcionamento do inconsciente, ao se deparar com o mecanismo do recalque e suas incidências na constituição dos sonhos, sintomas, atos falhos, entre outros. Por sua vez, Lacan observou que o recalque freudiano representa a própria resistência à significação, própria da estrutura da linguagem e, portanto, do inconsciente. $O$ recalque (Verdrängung) representa a substituição do significante do desejo da mãe, pelo significante Nome-do-pai, em uma operação de estabelecer uma forma específica de lidar com a falta: a estrutura neurótica. Nessa estrutura, o sintoma constitui uma metáfora do retorno do recalcado, no registro simbólico.

Quando essa operação de substituição do desejo da mãe, pelo significante Nome-do-pai (metáfora paterna), falha, ou, não acontece, temos uma estrutura psicótica, que vai lidar com a questão da falta, com uma outra forma de defesa: a recusa ou a foraclusão (Verwerfung). Na psicose, há uma falha primitiva na simbolização, fazendo com que, o que foi recusado, na ordem simbólica, reapareça, no real, sob a forma de alucinação e/ou delírio. Uma outra estrutura possível, é a estrutura perversa, que renega, ou desmente (Verleugnung) a castração materna, constituindo um fetiche, para ocupar o lugar do falo, que falta à mãe.

A metáfora paterna promove, não só a estruturação do sujeito, mediante sua inscrição perante a questão fálica, mas, também, mobiliza o sujeito no processo de identidade sexual, chamada, por Lacan, de "sexuação", ou seja, a forma como o sujeito vai se posicionar em relação ao falo. 


\title{
2.4 - Sexuação
}

A questão da diferença sexual, em Psicanálise, não tem a ver com a diferença anatômica (MOREL 1996). Freud nunca deixou de levar em consideração que, no ser humano, observamos a existência de uma bissexualidade, ou seja, não encontramos pura masculinidade, ou pura feminilidade, e que, a questão da diferença anatômica, entre os sexos, interessa menos que as conseqüências psíquicas dela decorrentes. Enquanto Freud e os neofreudianos abordam essa questão, a partir da perspectiva desenvolvimentista, Lacan abordou o sexo, pelo viés do gozo e da linguagem, radicalizando a tensão da diferença entre os sexos, marcada pela escolha do sujeito, ${ }^{12}$ e permeada pela intervenção significante.

Como se dá a incidência da metáfora paterna sobre a sexuação do sujeito? Com Freud, aprendemos que a primazia do falo aponta a organização de ambos os sexos, a partir dessa questão, e vimos com Lacan, que, em última instância, a questão do falo pode ser tomada como 0 representante de uma falta, para o psiquismo. A significação fálica é aquilo que permite aos seres falantes um posicionamento em relação ao desejo do Outro e, com isso, há uma articulação lógica com um resto não simbolizável, um "a mais", que se encontra para além do gozo fálico.

\begin{abstract}
"Sem a noção lacaniana de que o falo é um significante, todas as críticas a respeito do machismo contido na inveja do pénis e no complexo de masculinidado fazem sentido. (...) A crítica dos pósfreudianos faz algum sentido, no contexto em que se deu, pois o próprio Freud não conseguiu nomear seu rompimento com a referéncia biológica. Os pós-freudianos preferiram, ao contrário do que fez Lacan, abrir mão da premissa fálica do que desta referéncia. O que Lacan faz, então, é levar às últimas conseqüéncias a premissa fálica, transformando o falo no significante estruturador do desejo humano" (PRATES 2001, p. 79-80).
\end{abstract}

A questão da erogeneidade, ou não da vagina, na teoria lacaniana, é deslocada para a questão de estrutura, bem como as noções de "inveja do pênis" e "angústia da castração" são tomados como formas de se posicionar, perante o significante fálico. As relaçōes entre os sexos passam a ser reguladas pela dialética de ser, ou ter o falo, sempre, permeadas pelo fato que a função fálica se dá, sob os auspícios de um "véu", que encobre um vazio estrutural.

O falo é o parâmetro da constituição sexual, para ambos os sexos, constituindo um artifício forjado pela cultura, para lidar com 0 gozo inalcançável. $O$ fato de ser culturalmente definido, não o torna menos

\footnotetext{
${ }^{12} \mathrm{Na}$ estrutura neurótica, o sujeito pode consentir ou recusar a distinção sexual (menino ou menina) e a partir daí seu modo de gozar o conduzirá a se situar do lado todo fálico, ou do lado não-todo fálico. Nesse sentido, a escolha do sujeito pode opor a anatomia ao registro civil.
} 
operacional, uma vez que podemos operar, a partir da Linguagem, que também se localiza no plano da cultura (PRATES 2001).

MOREL (1996) aponta que o falo é tão artificial e arbitrário, quanto qualquer norma social, remetendo à própria passagem mítica da natureza à cultura, como produto primeiro e, portanto, universal, pois é nele que se fundamenta a interdiçāo e a lei civilizatória. As conseqüências disso são divergentes, para 0 homem e para a mulher: no menino, o desamparo existencial pode levar ao desespero, e ele pode recorrer ao pênis, para forjar uma razão carnal, em que há uma condição simbólica; para a menina, a situação é crítica, fazendo com que ela tenha que recorrer a outros artificialismos.

Embora a cultura ofereça ao sujeito o significado fálico, enquanto representante de um gozo perdido, há a necessidade de um operador ("Nome-do-pai") e uma operação (Metáfora paterna), para que o falo se transforme em significante $e$, assim, possibilitar a inscrição de uma posição do sujeito, perante o discurso sexual. MOREL refere que "Assim, o sujeito pode recusar ou aceitar o erro comum do discurso sexual. Se ele o recusa, é a psicose, o fora-do-discurso e ele deverá inventar uma sexuação inédita. Se ele o aceita, entra na sociedade humana fálica, inscreve seu gozo na função fálica única para poder significar a diferença sexual" (MOREL 1996, p. 123).

A sexuação depende de uma lógica de três tempos (MOREL 1996):

1. O tempo da diferença natural dos sexos;

O primeiro tempo equivale a um real mítico, pois ele toma seu valor no segundo tempo. A diferença anatômica natural pode ser assinalada no nascimento, ou, mesmo, antes dele, através de aparatos tecnológicos (ecografia, genótipo, etc), mas se espera que a escolha sexual se dê, a posteriori.

2. O tempo da escolha do sexo pelo sujeito;

No segundo tempo, temos o discurso sexual, no qual a percepção da diferença é permeada e estruturada pelo significante. A definição do "É menino!" ou "É meninal" é definida socialmente, sem se dar conta disso, por critérios fálicos. Quando da definição, menino ou menina, já há atributos qualitativos ali implicados. Para MOREL, "A natureza torna-se semblante"13, sucumbe ao peso do significante único fálico, que determina duas categorias humanas: uma supostamente dispondo de atributos fálicos e outra, supostamente castrada. O órgão natural se tornou organon, ou instrumento

\footnotetext{
13 LAIA traduziu esse texto de MOREL e aponta que o termo "semblante" como uma proposta para traduzir o termo usado por Lacan, "semblant". Em francês, o termo "semblant" não tem o sentido de "face", "rosto" ou "cara", como o que relacionamos em português com "semblante". O sentido de "semblante" em francês aponta para que o dicionário Aurélio traz como "sentido figurado". A raiz do verbo "semblant" em francês vem de "sembler", ou parecer, o que não se observa em português. A Psicanálise lacaniana se vale desse termo para designar uma posiçāo em que "parece ser sem nada esconder".
} 
significante. Nesse tempo, vemos que o discurso sexual opera uma mudança no estatuto do falo, fazendo deste um significante.

3. O tempo da sexuação, propriamente dita.

Com essa articulação, Lacan lidou com a questão: como um único significante pode inscrever dois sexos? Freud procurava resolver essa aporia, com uma inversão temporal no desenvolvimento dos dois complexos, de castração e do Édipo. Por sua vez, Lacan, através do conceito de sexuação, mostrou que, se há uma única função de gozo na linguagem, para dois sexos, há, entretanto, dois modos de inscrever isso, ou seja, há dois modos de gozo fálico. Para sexuar, o sujeito não se inscreve, diretamente, como "eu sou fálico" ou "eu sou castrado". O que ocorre é que o sujeito se inscreve, pelo modo de escolha de gozar do falo: se ele é tomado, totalmente, pela função fálica, é homem ou, se é tomado, parcialmente, na função fálica, é mulher.

Lacan recorreu a uma escritura lógica, para definir o real do sexo, levando em conta a questão de que a relação sexual é da ordem do impossível, inventando, assim, uma escritura da não-relação sexual. Sua preocupação era definir os dois sexos, como dois modos distintos de uso do falo, no seu laço com o outro sexo, ou seja, o sujeito tenta abordar o outro sexo, na sua forma distinta de se posicionar, em relação ao significante fálico, mas essa tentativa se mostra um desencontro, constituindo, sempre, um fracasso.

Quanto à "opção de identificação sexuada", o neurótico, muitas vezes, tem dificuldades em lidar com sua escolha inicial, recalcando-a e recobrindoa com uma série de identificações. Logo, a sexuação não se reduz a uma simples identificação significante, e a análise do sujeito vai desnudar todo esse processo, reconduzindo-o a essa escolha inicial. A histeria é um exemplo do recobrimento da escolha sexuada, na medida em que o sujeito, em questão, coloca em causa, justamente sua identificação sexuada, ou seja, sua posição em relação ao significante fálico.

Lacan elaborou um diagrama, contendo o matema, chamado "Fórmulas quânticas da sexuação", reproduzido a seguir:

Figura 2 - Diagrama das Fórmulas quânticas da sexuação

\begin{tabular}{|c|c|}
\hline Homem (Um) & Mulher (A Outra) \\
\hline$\exists x \cdot \overline{\Phi x}$ & $\overline{\overline{\Xi x}} \cdot \overline{\Phi x}$ \\
$\forall x \cdot \Phi x$ & $\overline{\nabla x} \cdot \Phi x$ \\
\hline$\$ \longrightarrow a \int_{\mathbb{A}}^{(\mathbb{A})}$ \\
\hline$\Phi \leftarrow a$
\end{tabular}

Fonte: LACAN 1985, p. 105 
Esse diagrama é constituído de duas partes fundamentais: o lado direito corresponde à estrutura da posição feminina, na sexualidade (cujo significante principal é o do Outro) e o lado esquerdo, à da posição masculina (cujo significante principal é o do Um). Cada uma dessas escrituras se refere a uma função única, a "função $\Phi x$ ", o que indica que a sexualidade humana se relaciona, em ambos os casos, com a função do falo $(\Phi)$ e que a diferença entre cada uma das posições ou identificações se situa no nível da fala, pela forma como cada um dos sujeitos se inscreve em relação à função do falo. ANDRÉ (1987) refere que não é a função fálica, ou a lei fálica, que os situa em determinada posição, mas, sim, a forma como cada sujeito se assujeita à função do falo.

O diagrama pode ser lido da seguinte forma:

- Do lado masculino, na parte superior esquerda do quadro:

$\exists x$. $\overline{\Phi x}$ : existe um sujeito, para quem a função fálica não funciona, ou, existe um homem que não se inscreveu na castração.

$\forall x$. Фx : para todo sujeito, é verdadeiro que a função fálica funcione, ou, todo homem está submetido à castração

Essa aparente contradição diz respeito à lógica, em que a exceção confirma a regra, e é encarnada pelo mito do pai primitivo freudiano, de "Totem e Tabu", o qual poderia gozar de todas as mulheres, ou da "mulher-toda", enquanto seus filhos seriam submetidos a ele, ou seja, castrados.

- Do lado feminino, na parte superior direita do quadro, temos:

$\overline{\exists x} . \overline{\Phi x}$ : não existe sujeito, para quem a função fálica não funcione, ou, não há nenhuma mulher que não esteja assujeitada à castração;

$\overline{\forall x}$. $\Phi x$ : para não-todo sujeito, é verdadeiro que o falo funcione, ou, a mulher é não-toda submetida à castração.

Do lado feminino, não temos uma exceção, não temos uma mulher equivalente ao pai totêmico, que foge à castração. As figuras femininas míticas são figuras fálicas, como por exemplo, as Amazonas. Nenhuma mulher funda o sexo "não fálico" e, portanto, não existe um "clã de mulheres", não há um conjunto fechado, com uma lei própria do lado feminino, pois elas, também, submetem-se à função fálica. Nesse aspecto, Lacan formula, logicamente, a ausência de uma identidade feminina, que pode ser lida, em Freud, metaforicamente, como a "não descoberta da vagina", como sexo não-fálico. Dessa forma, temos um vazio, uma falta, que pode ser tomada pelo matema $S(\mathbb{A})$, ou, significante de uma falta no Outro.

Os sujeitos que se posicionam, no lado feminino, têm que escolher entre duas vias:

1. Ou recusam essa falta de um fundamento, especificamente, feminino e, nesse aspecto, só thes restam se alinhar do lado masculino, para encontrar uma identidade e, assim, ingressar na inveja do pênis (penisneid), que pode evoluir para o complexo de masculinidade. 
Nessa vertente, também, encontramos a solução, em que as mulheres tentam fazer um "conjunto fechado" e, assim, só lhes restam se dizerem castradas, como os homens.

2. Ou aceitam a falta de um fundamento, especificamente, feminino e, nessa vertente, temos a proposta lacaniana, para avançar, perante o impasse freudiano, em que a constatação de que "A Mulher não existe" leva à conseqüência de que elas não podem formar, senão um "conjunto aberto", e devem ser contadas "uma por uma". As mulheres não formam um grupo, como os homens (não fazem "Um"), e permanecem em sua infinitude, ou seja, se inscrevem, apenas parcialmente, na função fálica. A feminilidade é algo que se desdobra diante da castração, havendo algo que não se submete, totalmente, a isso. O homem não pode encarnar, para ela, como o significante do Outro ( $(\mathbb{A})$ ), porque a mulher é um Outro que, em última instância, não existe, no nivel do gozo. Por isso, podemos grafar "A Mulher", já que esse " $A$ " ("esse a barrado") indica que não existe.

Na parte inferior do quadro, do lado feminino, a divisão do gozo se dá entre dois pólos: 0 do falo $(\Phi)$, que o homem pode encarnar para ela, e o de $S(A)$, como aquilo que falta, como significante, no Outro (é a própria representação do sexo feminino). O parceiro da mulher contribui, com a articulação fálica, mas a mulher não tira todo seu gozo do parceiro, e a articulação com $S(A)$ aponta, sobretudo, para um mais-além da contribuição fálica. O parceiro se frustra, pois não pode possuir toda-mulher, e ela goza, enquanto Outro dela mesma. Conseqüentemente, o homem não tem acesso a essa hiância, na qual a mulher ocupa o lugar do Outro, que falta.

Do lado masculino, temos que o homem aborda a mulher, pela possibilidade da elaboração da fantasia, como vemos no matema da fantasia (\$○a). Lacan indica que a mulher será um objeto parcial (objeto a), relativamente àquilo, que seria o corpo do Outro. Só resta ao homem abordar a mulher, pela fantasia, e os objetos pulsionais, ali indicados (olhar, voz, seios, pele, entre outros), mas nunca terá acesso ao corpo feminino, como tal. Ocorre uma radical alteridade, que pode ser observada, quando o homem expressa ansiedade, na abordagem do corpo feminino: a ele só resta a dúvida e a incerteza de tê-la, efetivamente, possuido, ou seja, de ter participado do gozo dela.

Essa divisão entre as posições sexuais (masculina e feminina) se dá, não apenas no nível da identidade, mas também, no nivel do gozo. A função fálica acaba por desdobrar o aspecto feminino, delimitando que, na mulher, há dois tipos de acesso ao gozo: o gozo fálico e o Outro gozo, ou seja, na mulher há uma parte presa ao gozo fálico, e outra, ligada ao que Lacan chamou de gozo do Outro, ou, gozo do corpo. Não se trata de posicionar a essência feminina, como esse Outro gozo, pelo contrário: a existência de um Outro gozo nos outorga afirmar que a mulher não existe, ou seja, não há 
uma essência feminina. Não podemos, portanto, criar dois conjuntos fechados: de um lado, os homens com seu gozo fálico $e$, de outro, as mulheres com o Outro gozo. O Outro gozo está para além da linguagem, ou, mesmo, fora dela e, por isso, é impossível de dizer, permanecendo como uma questão, um enigma.

\begin{abstract}
"É o gozo fálico, por seu lado parcial, fora-do-corpo, que nos leva a pensar num mais-além, num "mais" ou numa "outra coisa". Afinal, não é uma propriedade fundamental do significante - na medida em que ele é corte, delimitação de um bordo - evocar outra coisa além do que ele diz e produzir assim, literalmente, seu mais além" (ANDRÉ 1987, p. 223-224).
\end{abstract}

Lacan situa esse Outro gozo, como um efeito radical da função fálica, e aponta que ele não é complementar ao gozo fálico, mas sim, suplementar, ou seja, o Outro gozo só é invocado, a partir do advento da castração. Conseqüentemente, não podemos abordar o gozo não-fálico, senão pelo gozo fálico, ou seja, o gozo do corpo (o Outro gozo) só é possível ao sujeito, que se inscreveu no gozo parcial, limitado pelo órgão.

"Não é porque ela é não-toda na função fálica que ela deixe de estar nela de todo. Ela não está lá nāo de todo. Ela está lá à toda. Mas há algo a mais." (LACAN 1985, p. 100)

O significante do falo (o primado do falo, no sentido freudiano) constitui, assim, uma divisão do gozo. Isso implica uma impossibilidade de relação, sexo a sexo, de um "ser macho" e de um "ser fêmea", no que concerne à dimensão do ser humano falante. Só há o registro do semblante, ou seja, no humano, não podemos falar de instinto sexual, mas de uma série de pulsões parciais, das quais, nenhuma é, em essência, genital. Sem dúvida, essa é a grande contribuição da descoberta freudiana sobre a sexualidade, à medida que não há uma sexualidade "natural", isenta de viés (o viés introduzido pela lei fálica é, portanto, decisivo). Como resultante disso, a significação dos jogos das pulsões parciais é, sempre, faltosa, ou seja, nada vem unificar essas pulsões numa pulsão sexual global, que dê conta da relação de um sexo ao Outro sexo (ANDRÉ 1987).

Por isso, Lacan estabelece "Não existe relação sexual", ou seja, não existe completude no encontro sexual, o desencontro ali presente é estrutural. Sade explicita muito bem esse "jogo" ao escrever, em Julliete "Emprestai-me, senhora, a parte de vosso corpo que pode me satisfazer num instante, e desfrutai, se isso vos aprouver, da parte do meu corpo que vos possa ser agradável" (Sade, apud NASIO 1993, p.141).

A questão da castração, na mulher, segundo Soler (apud PRATES 2001), aponta a via de desejo do falo, do qual o homem é suposto portador e, assim, o lugar identitário para a mulher será o de objeto correlato ao desejo masculino. O que Soler observa, brilhantemente, é que o sujeito feminino, na verdade, posiciona-se, na relação sexual, fazendo semblant de objeto a, para que o homem a aborde. Há uma inversão radical da metáfora 
subjetiva, fazendo com que a problemática feminina se coloque no nível do ser, e não do ter. O sujeito feminino adota um "fazer-se-de-mais-de-gozardo-outro", com intuito de colocar-se em alguma posição, relativa ao desejo do outro.

Por não suportar o lugar inconsistente que the cabe, a mulher tenta agarrar-se ao falo, e engendra um artifício, que tenta forjar a proporção sexual inexistente.

\begin{abstract}
“A mulher só entra na relação sexual enquanto mãe. (...) Para esse gozo que ele é, não-toda, quer dizer, que a faz em algum lugar ausente de si mesma, ausente enquanto sujeito, ela encontrará, como uma rolha, esse a que será seu filho" (LACAN 1985, p. 49).
\end{abstract}

\begin{abstract}
"Se, como visto, uma mãe coloca seu filho no lugar de objeto a para suprir a não relação sexual, assim como o homem faz com a mulher, a saida da maternidado estaria articulada do lado do homem, e não ao lado da mulher. A proposta de LACAN, então, afasta-o de Freud, na medida em que coloca a construcão da feminilidade em Outro lugar, rompendo o curto-circuito fálico, sem abrir mão do falo como norma, ou melhor, como função. Na teoria freudiana, o alinhamento entre feminilidado e histeria é uma dedução coerente. Com Lacan, este alinhamento torna-se problemático, a partir de sua concepção de não-todo; ao menos nos mesmos termos da proposta de Freud" (PRATES 2001, p. 108).
\end{abstract}

PRATES (2001) refere que, em uma cultura de valorização do falo, a posição "não-toda" é difícil de ser sustentada, e não há mulher, que não tenha relação com a função fálica (na neurose). A neurose histérica pode ser tomada como uma tentativa de fazer "todo", do "não-todo", tomando, assim, uma posição masculina, uma barreira ao Outro gozo, pois a histérica se empenha em um gozo de castrar o mestre e, assim, não abandona o circuito do gozo fálico. Por empenhar-se nesse "fingir-se de homem", a histérica realiza um recobrimento da escolha sexuada, mas, que problematiza seu acesso ao Outro gozo.

A análise da mulher possibilitará que o sujeito histérico abra mão do lugar "toda-histérica", em direção à contingência da pulsação feminina, suportando a inconsistência do Outro gozo (PRATES 2001). Soler (apud PRATES 2001) aponta que, na proposta lacaniana de final de análise, 0 sujeito deverá "assumir o seu Outro gozo". Com isso, temos que, embora a análise não tenha o poder de modificar a "escolha" feita pelo sujeito, em relação às possíveis modalidades de gozo ("todo fálico" ou "não-todo fálico"), o que se desnudará, ao final, é que o sujeito, independente de seu sexo anatômico, deverá sustentar essa escolha inicial, visando à ética do desejo.

A tese lacaniana é que uma mulher só pode ter acesso ao Outro gozo, ao gozo para além do falo, ou, ao gozo suplementar, se puder aceitar sua "fraqueza" de ser "não-toda" para um homem, e o homem, por sua vez, assumir a posição de desejar a mulher, como parcial, como objeto a. Para a mulher, trata-se, não de negar a castração, mas de aceitá-la. $O$ discurso 
psicanalítico supōe encontrar, a cada passo, o falo em sua letra, tomado no filete de metáforas e de metonímias, no qual a sexualidade se reduz nas formações do inconsciente (MOREL 1996).

\section{5 - A sexuação na mulher e o discurso histérico}

A falta de um significante, que represente o sexo feminino, faz com que não reste à mulher outra alternativa, a não ser haver-se com o falo. A feminilidade, enquanto terceira saída do complexo de Édipo, em Freud, aponta para uma virada em direção ao pai, movida pelo desejo de obter dele o que foi, inicialmente, negado pela mãe. Ocorre uma identificação com o pai, pois a menina se dirige a ele, no intuito de obter o falo. Vemos, aqui, que a lógica do desejo histérico se dá pelo investimento psíquico da atribuição fálica ao pai, fazendo com que a histérica se identifique ao pai, enquanto portador do falo desejado. Podemos articular histeria e feminilidade nesse ponto, no qual, o sujeito histérico, ao demandar ao pai, enquanto detentor suposto do falo, que a livre da sedução materna, o que ela, realmente encontra, é um homem, também, desejante (e, portanto, também faltante). Como conseqüência disso, o desejo da histérica será, sempre, desejo de insatisfação, em um deslocamento metonímico infindável.

Na histeria, a alienação do desejo (do desejo do Outro) dá-se pela palavra, sob o modo de identificação, o que faz com que elas exibam, com seus sintomas, o efeito real da linguagem sobre o gozo no corpo. O sintoma tem a função de "dar a ver" aquilo que estava "velado", como uma escrita que, não podendo ser dita ("mal-dita"), inscreve-se no corpo e, por isso, pode tornar-se "maldita". A decifração do sintoma aponta para 0 desvelamento da verdade do desejo, que mostra, em última instância, o gozo imperativo, que clama por se fazer presente, na medida em que não pôde ser falado. Nesse sentido, há uma articulação entre sintoma e verdade, na histeria, se bem que uma verdade colocada, sempre, em questão.

A histérica mostra que o saber não é significação e que, ainda assim, há ali uma verdade, pois, para ela, a verdade se articula com o saber inconsciente, e se mostra no sintoma (o gozo encontra caminho no "no corpo da histérica"). O que se evidencia, no discurso da histérica, é que a verdade não pode ser dita toda, resta um lugar vazio de saber, e o significante extraído não pode se fazer completo: há, sempre, um semidizer da verdade.

Para Lacan (1992), o gozo se situa entre o saber e a verdade, sendo um limite simbólico para esta, ressaltando, assim, um lugar inacessivel, para - qual o desejo aponta. O discurso analítico se articula nesse nó, entre saber, gozo e verdade. A histérica, ao apontar que não pode dizer a "verdade toda" de seu desejo, articulado ao gozo, mostra, com seus sintomas, que não há acesso direto entre o saber produzido pela fala (pelo significante) e a verdade, que fica em suspenso, pela articulação com 0 gozo. É por isso, que SCHERMANN (2003, p. 162) afirma que "a psicanálise trata do saber não sabido que, como suposto, se articula". 
Perante a questão "o que é ser uma mulher?" falta qualquer resposta. $\mathrm{Na}$ falta de um pênis, a mulher investe seu próprio corpo, falicamente, ou seja, o corpo é tomado como objeto simbólico pela libido, como objeto que supõe ser aquilo, que falta ao outro. Em outras palavras, o corpo da mulher é tomado, como suposto objeto de desejo do outro.

\begin{abstract}
"Feminilidade, portanto, deixa de ser um atributo próprio da mulher como fémea da espécie - para surgir como protótipo de uma posição assumida frente à falta e à castração. Se sabemos que pênis não é falo, um homem também pode assumir uma posiçáo histérica, ou, então, uma posição feminina. Isso é bastante enfatizado por Lacan, que chega a falar em histéricos macho e fémea" (PRATES 2001, p. 88-89).
\end{abstract}

Além das questões clínicas, a equiparação da feminilidade à histeria possibilita formular uma hipótese, a respeito do laço social estabelecido pela mulher, antecipando aspectos, que designam a mulher na cultura (PRATES 2001). Para isso, podemos nos valer dos discursos propostos por Lacan (1992), em seu seminário 17 "O avesso da Psicanálise", à medida que os discursos, por ele articulados, perfazem o laço social.

O discurso do Mestre é aquele que pode ser equiparado à dialética hegeliana, do senhor e do escravo. Enquanto o senhor se posiciona do lado do significante mestre (S1), o escravo está para o saber (S2). O sujeito (\$) ocupa o lugar da verdade, e o que se produz, nesse discurso, é o objeto mais-de-gozar (a). O Mestre desconhece sua posição de sujeito barrado, e o seu desejo de saber fica interditado, na medida em que o escravo, enquanto detentor do "savoir-faire", satisfaz o desejo do mestre, antes mesmo de ele o saber.

No discurso da Histérica, vemos uma provocação do desejo de saber. Vemos o sujeito (\$), enquanto agente, instituir um Mestre (S1), que acaba por produzir um saber (S2) e que revela a verdade do objeto a (mais-degozar). A mulher encarna, para o homem, esse objeto a. $O$ discurso histérico evidencia a "fabricação" de um sujeito movido pelo desejo de saber e, assim, revela o limite da própria linguagem, apontando a verdade daquilo que está para além do simbólico, ou seja, o Real. Lacan aponta que "a verdade é irmã de gozo", ou seja, há um "fora-do-discurso", e a mulher, a partir da posição de desejante, mostra esse "semidizer" da verdade, encarnando esse objeto que representa o que está para além do mundano (LACAN 1992). Os discursos da Histérica, em relação ao Mestre, revelam que, aparentemente, a histérica deseja um Mestre, sobre o qual possa reinar, mas ela acaba por revelar ao Mestre que ele, também, é castrado (PRATES 2001).

A mulher, enquanto privada de falo, simboliza, para a Psicanálise, por meio do discurso da histérica, a relação que o ser falante tem com a interdição primária do gozo, ou, sua relação intrínseca com a falta. Trata-se da questão da instauração do desejo insatisfeito da histeria, a partir da 
célebre questão freudiana "o que quer uma mulher?" como paradigma da constituição do sujeito. A posição de Lacan, quanto à questão da histeria e da feminilidade, é de que há uma coexistência dos dois, numa mulher real, ou seja, a histeria é, sempre, parcial e uma mulher, sempre, excede sua histeria. Morel (1996), a partir de Lacan, sugeriu que a questão do feminino pudesse ser tomada, como um conjunto aberto, enquanto a histeria seria um conjunto finito, ou, um todo fechado, contendo o seu limite localizado dentro do conjunto aberto da feminilidade. O diagrama abaixo ilustra essa questão.

Figura 3 - Diagrama da relação lógica entre a mulher e a histérica

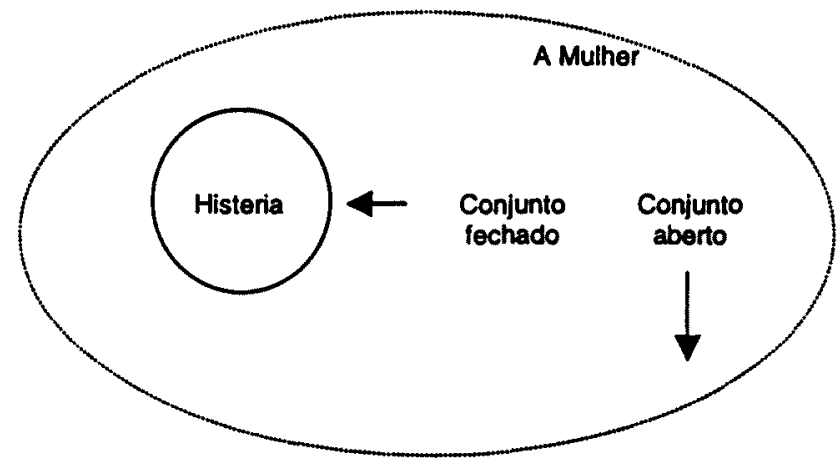

Fonte: MOREL 1996, p. 149

$\mathrm{Na}$ constituição do sujeito feminino, como dissemos, a mãe remete a filha a um marco, que pode lhe significar, mas que não a detém. A identificação fálica sublinha, assim, a exclusão do feminino da representação, e tem, como conseqüência, que a lei fálica instaurada pela função paterna não opera, por inteiro, na mulher, fazendo com que ela se situe, ao mesmo tempo, na lei $e$, em parte, fora-da-lei. Articulando esse aspecto com o diagrama acima, concluímos que, entre a histeria e a feminilidade, sempre, haverá um resto infinito, ou seja, sempre haverá uma não-toda, entre a fronteira ausente da feminilidade e o limite histérico. Lacan, ao propor o conceito de não-todo, pôs a existência da mulher como indeterminada e, assim, aponta que, no que se refere à posição feminina na sexuação, há o acesso a um gozo suplementar, que não se restringe ao limite do gozo fálico.

Mediante o percurso, até aqui exposto, consideramos importante destacar que, em nosso trabalho, tomamos a posição lacaniana como referência, para uma leitura, tanto do feminino, quanto da função da gravidez e da maternidade, em mulheres vivendo com HIV/Aids. Se, do ponto de vista freudiano, a maternidade era vista como insígnia idealizada para a verdadeira realização do feminino, a partir da concepção significante, na teoria lacaniana, podemos tomar a questão da maternidade como uma das 
possibilidades de escolha do sujeito, perante seu desejo inconsciente. Sem dúvida, uma das grandes contribuições da Psicanálise lacaniana foi apontar que o "tornar-se mulher" não tem, necessariamente, relação com o "tornarse mãe".

Consideramos, ainda, relevante, a explicitação de que não tomamos a questão do desejo feminino, "como um desejo natural de ter filhos" que, supostamente, faria com que as mulheres engravidassem. Isso seria adotar, não apenas uma posição essencialista, mas também, que implica a simplificação reducionista de uma estrutura lógica, que incide na constituição do sujeito. Sob o prisma psicanalítico, a noção de desejo nos remete à posição que o sujeito ocupa, em relação ao desejo do Outro, à castração e à Falta. Dessa forma, o desejo é uma conseqüência lógica, uma resposta que o sujeito constitui, para fazer frente à sua condição de ser, essencialmente, impotente e faltoso. A resposta, que o sujeito elabora, pode incluir a maternidade, mas a responsabilização do sujeito, perante seu desejo, não exige, necessariamente, que o sujeito se torne mãe, ou pai, de fato. Dessa forma, consideramos que a Psicanálise possibilita uma importante contribuição para abordagem do fenômeno, que constituiu o objeto de nossa investigação. 


\title{
Capítulo III - Contribuições da Psicanálise para uma leitura do objeto de investigação.
}

Nesse capítulo, buscamos traçar uma ponte para articular a questão do desejo, em Psicanálise, com o campo da Saúde Pública. Para essa tarefa, nos valemos de dois textos principais: o primeiro, de Lacan (1998b), intitulado "Subversão do sujeito e dialética do desejo no inconsciente freudiano", quando este articula a questão da produção do sujeito do inconsciente e a questão do desejo inconsciente; e o segundo, o texto de Zizek (1992) "O grafo do desejo: uma leitura política", que aponta as relações entre desejo e ideologia.

Lacan articulou o grafo do desejo, a partir de quatro formas sucessivas, que visam explicitar que a produção de significação é dependente de um "basteamento"14, ou seja, de uma "amarração" que produz o próprio sujeito. O "ponto de basta" é o ponto que permite, ao sujeito, uma "costura", ou uma ancoragem ao significante, possibilitando que o indivíduo seja interpelado, como sujeito. O ponto de basta constitui o ponto de subjetivação da cadeia significante e, através do "significante-mestre", o sujeito pode se posicionar.

Para o âmbito da saúde, poderiamos nos valer de vários significantes, como: tratamento, cura, prevenção, higiene, prognóstico, diagnóstico, intervenção, entre outros. Mas, quando tomamos esses significantes, basteados pelo significante "Saúde Pública", percebemos que se trata de um significante-mestre, que suplementa a cadeia significante, fornecendo 0 âmbito de significação para os demais significantes. Essa significação só pode ser tomada no depois (après-cours), pois a incidência desse significante-mestre permite um novo contexto (nova significação) para os significantes anteriores.

Nossa proposta do uso do grafo do desejo, para construção teórica de nosso objeto de estudo, justifica-se pela observação de que, através desse matema, o âmbito da constituição do sujeito desejante é articulado ao laço social.

\begin{abstract}
"Lacan soube extrair do texto de Freud a diferenca entre o eu ideal, que grafou com i, e o ideal do eu, I. No nivel desse l, vocês não têm nenhuma dificuldade de introduzir o social. Podem, perfeita $\theta$ legitimamente, interpretar o I do ideal como uma função social e ideológica. Aliás, é o que faz o próprio Lacan em seus Escritos: coloca uma política na base da psicologia, a ponto de podermos considerar lacaniana a tese de que toda politica é social. Ela o é, senão no nível em que investigamos o $i$, pelo menos no nivel onde fixamos o I." (Miller 1987, apud ZIZEK 1992, p. 109).
\end{abstract}

\footnotetext{
"A palavra "basta", segundo FERREIRA 1988, tem origem nos pontos grossos com que se atravessa o colchāo, coxim ou almofada para prender o enchimento, realizando o remate desses pontos.
} 
No primeiro nível do grafo, temos a cadeia significante com os elementos em uma função: $A$ (o grande Outro) ${ }^{15}$ e $s(A)$ (o significado do grande Outro). $O$ ponto de basta tem a função de fixar a significação dos elementos precedentes, submetendo-os, retroativamente, ao código, e assinalando suas relações mútuas, de acordo com esse código. Portanto, ele, o ponto de basta, é um significante singular, que ocupa um lugar excepcional na rede paradigmática do código, o que é denominado por Lacan, como o "Um", ou, o significante-mestre.

Nesse nivel do grafo, temos o processo de identificação do sujeito, constituido em dois niveis: a identificação simbólica [I(A)] e a identificação imaginária [i(a)]. No eixo $\mathrm{m}-\mathrm{i}(\mathrm{a})$, temos a representação da "identidade consigo mesmo" do sujeito, que ocorre no processo de identificação especular $^{16}$. No eixo, que liga o eu $(m)$ e seu outro imaginário [i(a)], o sujeito procede a uma identificação com o outro imaginário, ou seja, ele tem que se alienar, colocando sua identidade na imagem de seu duplo. Nesse nivel imaginário, o sujeito supõe que, sempre, esteve presente, desde o começo de seus atos $e$, assim, ele desconhece sua total dependência do grande Outro da ordem simbólica, como sua causa de descentração. $O$ estádio do espelho, na teoria lacaniana, aponta para a alienação constitutiva do sujeito, no outro imaginário.

\footnotetext{
"Basta compreender o estádio do espelho como uma identificação, no sentido pleno que a análise atribui a esse termo, ou seja, a transformação produzida no sujeito quando ele assume uma imagem - cuja predestinação para esse efeito de fase é suficientemente indicada pelo uso, na teoria, do antigo termo imago" (LACAN 1998e, p. 97).
}

Miller (apud ZIZEK 1992) refere que a identidade imaginária se relaciona com o "eu ideal" e a identidade simbólica, com o "ideal do eu"17 freudiano, sendo que, no nível da identificação imaginária, o sujeito se identifica com uma "imagem", que representa "o que gostaríamos de ser" e

${ }^{15}$ A noção lacaniana de grande Outro (A) é concebida como um espaço aberto de significantes que o sujeito encontra desde seu ingresso no mundo, trata-se de uma realidade discursiva. No texto "Subversão do sujeito e dialética do desejo no inconsciente freudiano", Lacan coloca que o grande Outro é o lugar do "tesouro dos significantes", ou seja, o lugar de onde se funda a ordem simbólica, ou seja, constitui a própria referência do simbólico. Da relaçāo $s(A) \Theta A$, temos a significação que aponta, em última análise, para a questão do furo no real, ou seja, para a questão da Falta que vai implicar a questão do desejo (KAUFMANN 1996).

${ }^{16}$ Esse processo de identificação é explicitado no texto de Lacan "O estádio do espelho como formador da funçāo do eu" de 1949, que foi publicado em português nos Escritos em 1998.

${ }_{17} \mathrm{O}$ "eu ideal" corresponde a uma formação intrapsíquica da ordem do superego. É essencialmente narcisica e tem origem na fase do espelho, portanto, tem seu registro no imaginário. O "eu ideal" serve de suporte à identificaçāo heróica. $O$ "ideal do eu" corresponde a uma instância psíquica da personalidade, resultante da convergência do narcisismo (idealizaçāo do ego) e das identificaçōes dos pais. É um modelo para qual o sujeito tenta conformar-se, mediante intervenção superegóica. (LAPLANCHE e PONTALIS, 1995) 
no que se refere à identificação simbólica, o sujeito se identifica pelo "lugar de onde somos observados, ou, o lugar de onde nos olhamos, de modo a parecermos merecedores de amor para nós mesmos" (ZIZEK 1992, p. 104).

A identificação costuma ser tomada como um processo, em que o sujeito se identifica com modelos de ideais, tentando imitá-los (heróis, cantores, desportistas, etc). Essa idéia pode ser desmistificada, se tomarmos em consideração dois pontos importantes (ZIZEK 1992):

1- O traço no outro, mediante ao qual nos identificamos, geralmente é oculto, podendo ser, inclusive, uma característica que não traga, necessariamente, prestígio. Dessa forma, o sujeito se identifica com a "fraqueza ou falha" do outro, mesmo que isso se dê, de forma inconsciente.

2- A identificação imaginária é, sempre, uma identificação para um certo olhar do Outro, o que aponta, em última análise, que o "ser para o outro" pode ser tomado como o "ser para si", pois o próprio sujeito já está simbolicamente identificado com 0 olhar, para 0 qual desempenha esse papel. Na neurose histérica, é bastante comum, observarmos que o sujeito não se posiciona, enquanto desejante, furtando-se da responsabilidade perante seu desejo e culpando o outro ("eu sou o que sou, porque o outro não me deu o que preciso", ou, "Porque o outro não me reconheceu como eu mereço").

A identificação simbólica $[I(A)]$ depende da relação do sujeito com a ordem simbólica, ou seja, da identificação do sujeito com algum traço significante (I) do grande Outro (A) da ordem simbólica. Esse traço "representa o sujeito para outro significante", assumindo a forma de uma missão, ou um nome que o sujeito recebe. Na função $i(a)$, identificação imaginária, destacam-se significantes extraordinários, que marcam o indivíduo, "um traço positivo descritivo, que nos fascina e representa algo que gruda ao individuo, algo que se oferece ao nosso olhar, alguma coisa vista" , mas esse traço, por si só, não revela o ponto de onde o indivíduo é observado.

Zizek (1992) frisa que a função i(a) já está, sempre, subordinada ao $\mathrm{I}(\mathrm{A})$, pois é a identificação simbólica (o ponto de onde somos observados) que domina e determina a imagem, a forma imaginária em que parecemos dignos de amor a nós mesmos. Na identificação imaginária, imitamos o outro, no nivel da semelhança, ou seja, identificamo-nos com a imagem do outro, de forma a "ser como ele", o que pode ser visto no processo, em que o sujeito se identifica imaginariamente com o herói, ou com um ideal heróico. A identificação simbólica aponta para uma outra questão, pois o sujeito se identifica com o outro, precisamente no ponto em que ele é inimitável, ou seja, no ponto em que escapa à semelhança, mas que persiste em se fazer representar, constituindo um traço que aponta para um resto, para além da significação. 
$\mathrm{Na}$ passagem do primeiro nivel do grafo para o segundo nível, temos - processo, que descortina a articulação $i(a)$ e $I(A)$, e que aponta para a questão do desejo (Che vuoi?).

Figura 4 - Grafo do desejo: "Che vuoi?"

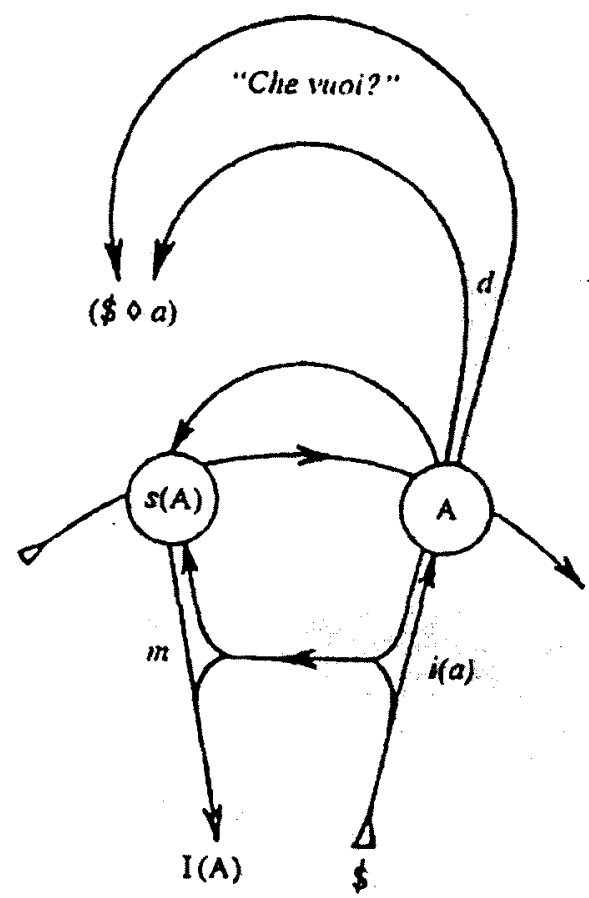

Fonte: LACAN 1998b, p. 829

Nesse ponto da construção do grafo, o sujeito integrado, no campo sócio-simbólico, e que assumiu certas "missões", sob o domínio da identificação simbólica, vê-se perante uma questão, que ele toma como vinda do Outro, o Che vuoi? (ZIZEK 1992, p. 109).

QUINET (1991) retoma a dissimetria, proposta por Lacan, entre os pontos A (o grande Outro, como um lugar do tesouro dos significantes) e $\mathbf{s}(\mathrm{A})$, como uma relação de escansão, ou seja, há uma pontuação em que a "significação se constitui como produto acabado". Se a estrutura da relação significante/significado tem esse "arranjo", torna-se lógico afirmar que, no lugar do Outro (A), deveria estar instalada toda a bateria dos significantes, uma completude. Entretanto, o que se observa, é que há uma inconsistência no grande Outro, à medida que lhe falta o significante, que irá constituir e garantir o caráter de verdade absoluta. Lacan, então, indica que esse grande Outro não pode mais ser tomado como o lugar do "tesouro dos significantes", mas como "um sítio prévio ao puro sujeito do significante", ou, como o "lugar da fala", sustentando, assim, que, embora inconsistente, esse grande Outro, nesse nível do grafo, promove efeitos decisivos de 
significação. Quando o sujeito se depara com a pergunta índice de desejo (situado no grafo como o $d$ minúsculo à direita) e, portanto, indicativa de uma falta (Che vuoi?), o grande Outro pode mostrar sua inconsistência, havendo a subida para o próximo patamar do grafo, onde o temos [S(A)].

"Mas, esse lugar do sujeito original, como haveria este de encontrá-lo na elisão que o constitui como auséncia? Como reconheceria ele esse vazio como a Coisa mais próxima, mesmo escavando-o de novo no seio do Outro, por nele fazer ressoar seu grito? Antes, ele se comprazerá em encontrar ali as marcas de resposta que tiveram o poder de fazer de seu grito um apelo. Assim, ficam circunscritas na realidade, pelo traço significante, as marcas onde se inscreve a onipoténcia da resposta. Não é à toa que essas realidades são chamadas de insignias. O termo, aqui, é nominativo. É a constelação dessas insignias que constitui para o sujeito o ldeal do EU" (LACAN. 1998f, p. 686)

Vemos, então, que o sujeito se depara com um problema: o processo de identificação do sujeito não consegue garantir que a identidade construída possa ser "plenamente satisfatória", ou seja, o sujeito continua perante um hiato, ou um resto, que resiste à significação, e que é da ordem do real. Nesse sentido, nem o imaginário, nem o simbólico, são capazes de fazer frente ao real, pois ele insiste, ou mais que isto, ele persiste, presentificando-se na dimensão do desejo.

\begin{abstract}
"Não há outro meio de conceber a indestrutibilidade do desejo inconsciente - como não há necessidade que, ao ver proibida sua saciação, estiole, em último caso consumindo o proprio organismo. $E$ numa memória, comparável ao que é chamado por esse nome em nossas modernas máquinas de pensar (baseadas numa realização eletrónica da composição significante), que jaz essa cadeia que insiste em se reproduzir na transferéncia, $\theta$ que é a de um desejo morto. É a verdade do que esse desejo foi em sua história que o sujeito grita através de seu sintoma (...)" (LACAN 1998d, p. 522)
\end{abstract}

Outro ponto, que aponta para a dimensão do real, é a própria inconsistência do Outro, na medida em que não fornece, para o sujeito, uma "garantia" de verdade. Não podemos dizer que há significação da significação, pois não há um sentido final, assim como não há o Saber Absoluto hegeliano. Ao Outro falta, justamente, o significante, que possa responder por um "eu sou", ou seja, no nível da linguagem, não há um significante que possa fixar o sujeito, para todo sempre, e algo que garanta o seu ser. "Não há um Outro, por mais institucionalizado que seja, que possa garantir a existência do Outro a quem endereço minhas demandas: não há transferência da transferência, nem tampouco 0 verdadeiro sobre 0 verdadeiro", aponta QUINET (1991, p.66).

O analista pode ocupar esse lugar de Outro, em função da própria fala do analisante, na constituição da transferência, pois é para o analista, no lugar de grande Outro, que o analisando vai endereçar suas demandas. Será, por intermédio da resposta de "não-resposta" da demanda, que o 
analista implicará o sujeito em sua fala, ou seja, pela escansão dos significantes, pelo corte da sessão, 0 analista promove a desidentificação do sujeito e faz, assim, surgir a dimensão do desejo, que se apresenta, sempre, como um enigma, uma questão: "Por que ele me parou aí?", "O que eu falei de importante?" ou "Será que eu falei alguma besteira?". A questão sobre o desejo é, portanto, uma questão sobre o desejo do Outro, o Che vuoi? é um "Que queres?", ou "O que o Outro, encarnado no analista, quer de mim?". O analista, respondendo desse lugar, conduz 0 analisante a um questionamento da idealização comandada pela identificação simbólica [I(A)], pondo em questão o desconhecimento que o sujeito tem da sua faltaa-ser, que a idealização procura escamotear. $O$ analista procede, assim, $\grave{A}$ acentuação da submissão do sujeito às suas identificações primeiras, e põe em jogo a dimensão do desejo inconsciente, que surge como um enigma, um $x$, como uma incógnita a ser decifrada (QUINET 1991).

Vemos, então, que o Che vuoi? tira o sujeito do "conforto" da identificação imaginária. Perante a pergunta do desejo, surge a fantasia, como uma resposta, ou seja, como uma tentativa de preencher o vazio criado pela pergunta. Trata-se de uma construção, que o sujeito engendra, para preencher a abertura deixada pelo desejo do Outro, em uma tentativa de escapar do trauma insuportável de que o Outro fantasmagórico, horripilante em sua interpelação, quer algo de nós. Esse Outro horripilante nos propõe uma missão que é, por mais que o sujeito tente, indecifrável para o sujeito: eis aí o verdadeiro trauma, pois o sujeito é incapaz de traduzir o desejo do Outro, ainda que isso seja a única referência que ele possui.

Do lado do analisando, temos "Por que você está me dizendo isso?" $\theta$, do lado do analista, temos "Você está me pedindo algo, mas o que quer realmente? A que visa com esse pedido (demanda)?". Na neurose histérica, temos a clássica distinção entre demanda e desejo, pois a histérica demanda da seguinte forma: "estou the pedindo isso, mas, na verdade, peço-Ihe que recuse meu pedido, porque não é isso que eu querol". Nesse aspecto, quando a histérica solicita que alguém ocupe a posição de mestria, dizendo o que ela deve ser ou fazer, ela, imediatamente, denuncia, ou "castra" o mestre, fazendo com que este se torne "insuficiente". Com essa "estratégia", o que a histérica visa preservar é o próprio desejo, pois sua insatisfação aponta para a impossibilidade de completude. Em outras palavras, a histérica quer manter o desejo, ela tem "desejo de desejo", e a única forma de faze-lo, é sustentar, não importa como, a insatisfação do desejo, sem que, contudo, haja qualquer implicação de sua parte, pois é o Outro que falha, a falta está contida no Outro, e não, nela própria.

Podemos abordar a questão da angústia, como propõe Lacan (1997b), no seminário $X, e$, a partir daí, podemos desdobrá-la em planos distintos. O sujeito, ao apresentar uma queixa, denota, através de seu sintoma, um afeto, que pode ter uma relação mais próxima dos objetos da realidade, entretanto, no decorrer do processo analítico, perante a questão do desejo (Che vuoi?), o sujeito se vê diante de um "afeto que não engana" 
e que tem função mediana (e não mediadora) entre desejo e gozo. O que resta ao sujeito é haver-se com a angústia, que a abertura, cavada pelo desejo do Outro, produziu. Assim, Lacan aborda a angústia, como um objeto diferenciado da realidade do mundo, sendo, de fato, um sinal da emergência do objeto, no seu estatuto de Real, no âmbito da realidade psíquica.

Para lidar com a emergência da angústia, perante a questão do desejo do Outro, o sujeito lança mão do Amor: o sujeito oferece-se ao Outro, como objeto de seu desejo, respondendo ao Outro: como "Sou o que te falta, com meu sacrifício a ti, eu te preencherei e te completarei. Assim serei novamente completo". A operação do amor é dupla, pois o sujeito preenche a sua própria falta, ao se oferecer ao Outro, como objeto que preenche a falta no Outro. A desilusão do amor ocorre, quando a superposição de duas faltas não anula o vazio, pelo contrário, o desencontro de demandas é apenas uma questão de tempo (ZIZEK 1992). No processo analítico, o analisando tenta fugir desse abismo, representado pelo enigma do desejo do grande Outro, oferecendo-se como objeto de desejo, através do amor de transferência. A dissolução da transferência se dá, quando o sujeito renuncia a preencher o vazio, a falta no Outro, suportando a operação da castração.

A fantasia, também, é uma construção, que tem dupla função. Em primeiro lugar, serve de anteparo ao enigma insustentável do desejo do Outro (Che vuoi?). Nesse ponto, podemos compreender o matema da fantasia, situado à esquerda do gravo $\$ \diamond \mathrm{a}$, onde lemos "sujeito barrado, punção e objeto a", onde o elemento punção $(0)$ serve de anteparo para sustentar uma relação possível entre o sujeito e o objeto a (enquanto maisde-gozar). Por outro lado, a fantasia permite que o sujeito deseje algo. Isso significa que é, através da fantasia, que o sujeito aprende a desejar, o que vai além da questão da pura "satisfação de desejos". A fantasia constitui o desejo e, paradoxalmente, pode ser tomada em primeiro lugar, como uma defesa perante o enigma do desejo do grande Outro e, por outro lado, como um anteparo, que esconde o vazio, ou, o abismo do desejo do Outro. 
Na forma final do grafo de desejo, temos dois níveis: o nível da significação e o nível do gozo.

Figura 5 - Grafo do desejo completo

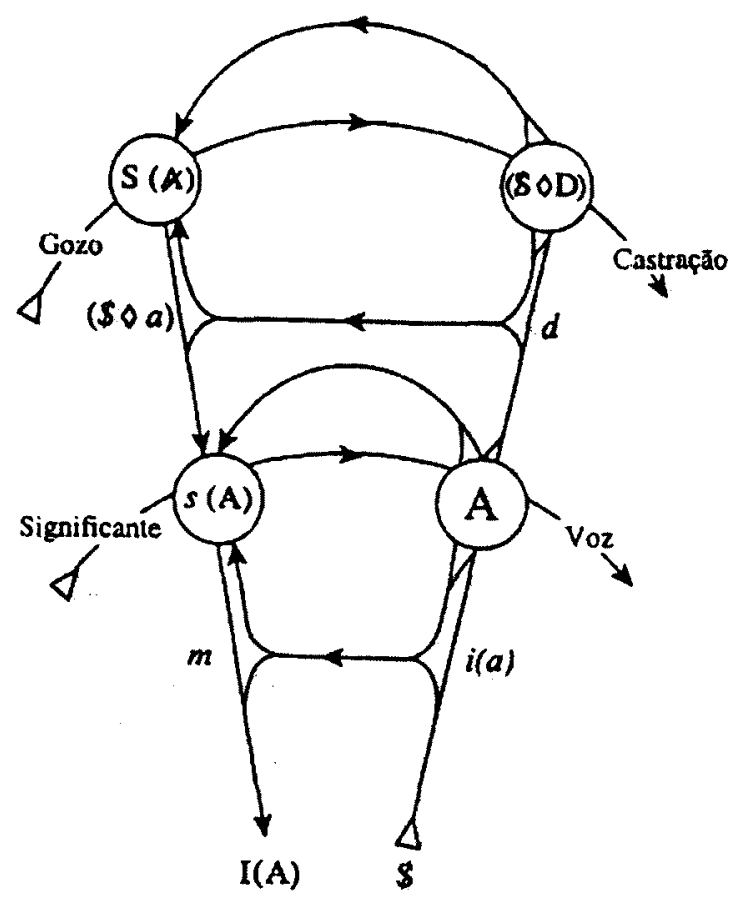

Fonte: LACAN 1998b, p. 831

No segundo nivel (superior), temos a questão do surgimento da inconsistência do grande Outro, ou seja, quando o próprio campo da ordem significante é perfurado e penetrado por uma corrente real pré-simbólica de gozo. O corpo, enquanto gozo encarnado, faz-se apreender na rede significante e essa incidência faz com que ele (o corpo) seja submetido à castração. O corpo sobrevive mutilado, desmembrado e mortificado e, embora the tenha sido retirado algo de gozo, a castração introduz uma "delimitação", um lugar limitado, onde o sujeito pode tentar situar-se.

Portanto, é possivel perceber que, no primeiro nível do grafo, no que concerne à identificação imaginária e simbólica, sempre, haverá um resto não simbolizável, que aponta para a inconsistência do Outro (o furo do Outro). Em função disso, o sujeito pode deparar-se com a questão do desejo $e$, através da fantasia, efetuar uma construção, que tenta fazer frente ao real de gozo (objeto a). 
Zizek (1992) assinala que a análise da ideologia permite efetuar uma desconstrução do que se passa no nível inferior do grafo do desejo, ou seja, no nivel da identificação simbólica e da identificação imaginária. $A$ análise da ideologia se dá sobre a forma como ela incide sobre o discurso, ou seja, a forma como os significantes ganham um sentido, a partir de determinados pontos de basta e, dessa forma, constituem um campo unificado de saber, ou de uma significação, que pode ser ideológica. Mas, "nem tudo é ideológico", pois há algo para além da ideologia dos discursos e, nesse sentido, a Psicanálise pode ser esclarecedora, ao apontar que "nem tudo é significante" e que há um aspecto que vai "para além do sentido", que é da ordem do gozo. Em virtude dessas consideraçōes, Zizek aponta para dois métodos complementares da "crítica da ideologia":

1- O nível da análise discursiva: nesse nível efetua-se uma leitura sintomal do texto ideológico, promovendo uma "desconstrução" da experiência espontânea de seu sentido. Nesse âmbito, é possível demonstrar como um dado campo ideológico é o resultado de uma montagem de "significantes flutuantes" heterogêneos, em função de determinados "pontos de basta". É possivel apontar os pontos em que a identificação imaginária e simbólica funcionam, em função de um discurso ideológico prévio, ou seja, como os nomes significam a priori, ou como os traços descritivos positivos funcionam como "designadores rígidos". Por meio de um trabalho de deslocamento e condensação (metáfora e metonímia), podemos chegar a determinar um sentido, para explicar determinados fenômenos sociais.

2- O nível da análise do núcleo de gozo: nesse nível, efetua-se a articulação, para além do campo da significação, ou, para além do sentido. A ideologia se instaura no campo de sentido, para manipular e produzir um gozo pré-ideológico, que se evidencia na estruturação da fantasia. Se a fantasia é, fundamentalmente, um roteiro, que tenta "tapar" ou cobrir o espaço vazio deixado pelo real, encarnado pela impossibilidade de simbolização, ou "a não existência da relação sexual", a fantasia será uma construção, que visa uma obturação do vazio, que é algo que não pode ser simplesmente interpretado, mas precisa ser atravessado. O sujeito tem que, ele mesmo, deparar-se com o "nada", que há por trás da máscara da fantasia. Zizek sinaliza que "a fantasia é um meio de a ideologia levar, antecipadamente, em conta, sua própria falha" (p. 124). Tanto a identificação imaginária, quanto a simbólica, falham, pois, sempre, há um resto não simbolizável de gozo. A função da fantasia ideológica é tentar mascarar essa inconsistência.

Nossa proposta, neste trabalho, baseando-nos em Zizek (1992), foi buscar explicitar o processo ideológico e, assim, apontar quais os significantes que se evidenciam, no processo de identificação imaginária [i(a)] e identificação simbólica [I(A)] entre mulheres vivendo com HIVIAids. Nesse sentido, destacamos a contribuição da Psicanálise lacaniana, 
mediante suas assertivas lógicas, para uma leitura do material de pesquisa de campo deste trabalho. 
Capítulo IV - Hipóteses de trabalho e Objetivo

\section{1- Hipóteses do trabalho}

- A gravidez e a maternidade em mulheres vivendo com HIV/Aids constituem possibilidades de elaboração para lidar com as questões da vida e da morte;

- $\quad$ desejo inconsciente pode interferir em decisões reprodutivas de mulheres vivendo com HIV/Aids, segundo a perspectiva psicanalitica;

- O discurso vigente entre profissionais de saúde, sobre gravidez e maternidade de mulheres soropositivas, apresenta-se ambiguo, pois o mesmo pode variar, da aceitação e acolhimento, até hostilidade declarada

\section{2 - Objetivo:}

Conhecer como as mulheres vivendo com HIV/Aids percebem e atribuem sentido às suas decisões reprodutivas, bem como caracterizar as diferentes formas de manifestação do desejo inconsciente, a partir do prisma psicanalítico. 


\section{Capítulo V - Procedimento metodológico}

\section{1 - Referencial teórico-metodológico}

Nosso objeto de investigação, ou seja, a questão do desejo em mulheres vivendo com HIV/Aids, aponta para uma complexidade, que envolve conceitos, como feminilidade, desejo, maternidade, inconsciente, gênero, entre outros. Nesse sentido, o presente trabalho é resultado de um percurso, que visa a construção de um diálogo entre o campo da Saúde Pública e o campo psicanalítico.

ALVARENGA (1994) caracteriza a Saúde Pública como uma interdisciplina cientifica, cuja área empírica é passivel de ser explorada por dois grupos de ciências, as naturais e as sociais. Embora seja possível uma cooperação entre esses campos, também se observam certos desafios metodológicos. $O$ objeto da Saúde Pública, pela especificidade de sua natureza bio-psicossocial - caracterizado pelos processos de saúde/doença e vida/morte - traz um trabalho interdisciplinar em diferentes níveis, além do tratamento de termos específicos de diferentes disciplinas ou campos, a necessidade de se contemplarem diferentes niveis de análise. Nesse âmbito, as questōes ontológicas, relativas a diferentes formas de abordagem do mesmo objeto, promovem, por um lado, o enriquecimento do Campo da Saúde Pública, por outro, um desafio metodológico na proposição de novos esquemas teórico-metodológicos de explicação.

Desde o princípio, nossa opção metodológica conduziu a proposta de investigação, ou seja, realizamos entrevistas permeadas por um roteiro prévio de questōes. No que concerne ao método propriamente psicanalítico, a técnica de associação livre e a proposição de um setting analítico são fundamentais para garantir a possibilidade de elaboração de um vínculo transferencial específico para com o analista, bem como o surgimento de elementos que apontam para questōes inconscientes, articuladas com o processo transferencial dessa relação estabelecida entre analisando/analista.

No método de investigação deste trabalho, estabelecemos, portanto, um roteiro de questöes que orientavam a condução da entrevista, o que permitiu uma leitura do sentido que a incidência do diagnóstico da infecção pelo HIV efetua nas decisões reprodutivas de mulheres vivendo com HIVIAids.

Sem dúvida, não pretendiamos elaborar um "instrumento" que almejasse mensurar o desejo, propriamente dito, pois não consideramos isso possivel, nem mesmo razoável. É evidente, para quem tem experiência em Psicanálise, que o desejo humano não é um "objeto" de estudo, passível de ser circunscrito dessa forma. Isso se dá, justamente, porque no que concerne à dimensão do desejo, no humano, algo sempre escapa, algo sempre excede e esse "excesso" não é passivel de ser "educado 
ortopedicamente". O Inconsciente introduz a possibilidade de instaurar objetos de estudo, que não obedecem à lógica da ordem do Consciente.

Nosso objetivo foi incluir a questão do desejo do sujeito subjetivado, a partir da escuta do seu discurso, apontando para a dimensão do Inconsciente, como produtor de uma lógica específica que pode vir a interferir no comportamento das mulheres, em questão. Embora o método não tenha sido, stricto sensu, psicanalítico, houve a produção de ultrapassagens, ou seja, o método de investigação proposto, permeado por uma escuta que toma o inconsciente como causa, permitiu a abertura para um campo mais complexo e amplo.

Dessa forma, a Psicanálise pode ser tomada como referência para apontar que, no discurso do sujeito, há algo que indica sua posição em relação ao Inconsciente e à Falta. As formaçōes do inconsciente podem indicar que, naquele momento, o sujeito do Inconsciente se manifestou e mediante uma pontuação do entrevistador, o sujeito pode buscar um sentido para o que ele produziu, através de seu discurso. Devemos, portanto, tomar o cuidado de fazer com que o próprio sujeito seja engendrador do sentido, servindo o pesquisador apenas como um elo de ligação, como um interlocutor interessado nessa produção de sentido. Devido à própria natureza do Inconsciente, o que aparece, que é da ordem "do para além do sentido" é sempre algo que "escapa" ao sujeito, mas que uma escuta atenta é capaz de captar.

Neste trabalho, adotamos duas vertentes de análise: por um lado, a análise da produção de sentido do discurso, e, em outro âmbito, apontar o campo que lida com o sem sentido, bem como para além do sentido do discurso.

No tocante ao nivel de análise de produção de sentido do discurso, adotamos, como referência, a proposta de análise de Spink (2000) e Castro (2001), estabelecendo, a princípio, uma linha narrativa, que visa apresentar a entrevistada e qual o sentido do discurso produzido.

No campo da Psicologia Social, a perspectiva construcionista tem sido referência para pesquisas realizadas no Núcleo de Pesquisa em Psicologia Social e Saúde do Programa de Pós-graduação da Pontifícia Universidade Católica de Sāo Paulo (PUC-SP), coordenado pela Prof" Dr" Mary Jane Paris Spink. As produçōes desse núcleo são norteadas pelas publicaçōes dessa autora que, adotando a postura epistemológica construcionista, reconhece que o conhecimento é uma produção humana social e volta suas investigações para os fenômenos coletivos, ligados à patologia/saúde, levando em conta o fazer humano nas suas práticas discursivas cotidianas.

As reflexões teóricas sobre a produção de sentido, como prática social, estão ancoradas em dois pontos centrais: o referencial teórico construcionista e a centralidade das práticas discursivas. A produção de 
sentido, essencialmente dialógica, implica no uso de conceitos expressos em linguagem e busca entender as práticas discursivas cotidianas, bem como os repertórios utilizados para a produção dos discursos (SPINK 2000). Trata-se de uma forma específica de pesquisar, em Psicologia Social, que tem foco na Saúde Pública (SPINK 2000, p. 9).

SPINK (2000) aponta que a disciplina construcionista tem, como fundadores, SCHELER e MANNHEIM, e que, através da Sociologia do conhecimento, focalizaram questōes epistemológicas referentes ao campo empírico, à história das idéias e à história das ciências. BERGER e LUCKMANN partem dessa perspectiva epistemológica, mas reorientam seu ponto de reflexão, visando o conhecimento do senso comum, em uma crítica ao intelectualismo, que poderia restringir a produção de conhecimento. Berger e Luckmann (apud SPINK 2000) propõem que a realidade é uma construção social e que a Sociologia do Conhecimento deve analisar como essa construção se dá. Esses autores procuram responder como os significados subjetivos se tornam facticidades objetivas e, para isso, constroem três conceitos fundamentais: a tipificação, a institucionalização e a socialização.

A tipificação é um conceito que toma a sociedade, fundamentalmente, como um produto humano, ou seja, a realidade é construída socialmente. Trata-se de uma proposta interacionista, em que a realidade cotidiana é tomada como as próprias interações com o outro. $O$ outro é apreendido a partir de esquemas tipificadores, como por exemplo, gênero, raça, etc. 0 conceito de institucionalização é construido a partir da idéia de que a sociedade é uma realidade objetiva, sendo que o processo de institucionalização vai situar essa objetividade social. Os esquemas tipificadores, a partir do qual o outro é apreendido, tornam-se habituais e autónomos, sendo transmitidos de geração em geração, gerando a objetividade percebida. A socialização pode ser tomada em duas vertentes, a socialização primária e a secundária. Esse conceito diz respeito à forma como a objetividade instituida é internalizada, o que nos mostra que o ser humano é um produto social.

Berger e Luckmann (apud SPINK 2000) ressaltam que o modelo de socialização, embora conservativo, não é estático, ou seja, a transformação social é possível, mediante rupturas e enfrentamento do não-familiar, num processo de ressignificação dos modelos tipificados. Enquanto Berger e Luckmann, na condição de sociólogos, preocupam-se com os processos de conservação e transformação social (focam nos processos de tipificação, institucionalização e socialização), Gergen, psicólogo social, foca seu estudo na interação entre os sujeitos, ou seja, no momento da produção de sentidos, na vida cotidiana. Gergen define a investigação construcionista como aquela que "preocupa-se, sobretudo com a explicação dos processos, por meio dos quais as pessoas descrevem, explicam ou dão conta do mundo (incluindo a si mesmos) em que vivem" (apud SPINK 2000, p. 26). Como conseqüência disso, deixamos o enfoque tradicional, que procura explicar os 
processos de conhecimento, como internos à mente, para focar a exterioridade dos processos e estruturas da interação humana.

Segundo a perspectiva construcionista, construímos repertórios interpretativos para dar sentido ao mundo. O processo de reflexão, que possibilita $\circ$ questionamento dessas construções conceituais, que acabam por se transformar em crenças, é chamado de "desconstrução" ou "desfamiliarizaçāo". Ibáñez (apud SPINK 2000) refere que o processo de desconstrução incidirá sobre quatro temáticas do realismo fundante da retórica da ciência, na modernidade, as quais, na verdade, se constituem como crenças: a dualidade sujeito-objeto; a concepção representacionista do conhecimento; a retórica da verdade e o cérebro, como instância produtora do conhecimento.

SPINK (2000) aponta que as práticas discursivas constituem o foco central e o solo de sustentação da abordagem construcionista e constituem um caminho privilegiado para entender a produção de sentidos no cotidiano.

\begin{abstract}
"É importante retomar em seus diversos aspectos o contexto histórico do qual emerge o projeto teórico-metodológico do estudo da produção de sentidos a partir das práticas discursivas, pois é esse o solo que the dá sustentação e possibilita seus desenvolvimentos. Propor que a produção de sentidos a uma força poderosa e inevitável da vida em sociedade e buscar entender como se dá sentido aos eventos do nosso cotidiano fizeram com que novos horizontes se abrissem $\theta$ novas perspectivas pudessem ser consideradas" (SPINK 2000, p. 3839)
\end{abstract}

SPINK e MEDRADO (2000) lembram que o "sentido é uma construção social, um empreendimento coletivo, mais precisamente, interativo, por mejo do qual as pessoas - na dinámica das relações sociais historicamente datadas e culturalmente localizadas - constroem os termos a partir dos quais compreendem e lidam com as situações e fenómenos à sua volta" (p. 41). A partir desse conceito, "a produção de sentidos não é uma atividade cognitiva intra-individual, nem pura e simples reprodução de modelos predeterminados. Ela é uma prática social, dialógica, que implica a linguagem em uso. A produção de sentido é tomada, portanto, como um fenômeno sociolingüistico - uma vez que o uso da linguagem sustenta as práticas discursivas que atravessam o cotidiano (narrativas, argumentaçōes e conversas, por exemplo), como os repertórios utilizados nessas produçōes discursivas" (p. 42).

Essa abordagem teórico-metodológica toma a linguagem, como prática social, ou seja, a linguagem em uso, e busca trabalhar a interface entre os aspectos performáticos da linguagem e as condiçōes de produção (contexto social e interacional). A produção de sentido trabalha em diferentes niveis de análise, tornando-se necessária a distinção entre os conceitos de discurso e práticas discursivas. 
O conceito de discurso, nessa perspectiva, refere-se às regularidades lingüisticas, ou ao "uso institucionalizado da linguagem e de sistemas de sinais, de tipo lingüístico" (Davis e Harré 1990, apud SPINK 2000). Esse processo de institucionalização dos discursos ocorre, tanto em nivel macro (sistemas políticos e disciplinares), como em grupos sociais especificos (um sindicato ou partido, por exemplo), como expressão de que diferentes estruturas de poder têm seus discursos específicos, que não podem ser descontextualizados historicamente.

Se tomarmos o conceito de discurso assim definido, aproximamo-nos do conceito de linguagens sociais de Bakhtin, para quem, as linguagens sociais sāo discursos específicos da sociedade (de uma profissão, de um grupo etário, entre outros), num determinado contexto histórico. Para Bakhtin, o contexto ou situação molda os gêneros da fala ou speech genres, ou seja, a forma e o estilo das enunciações (Bakhtin 1995, apud SPINK 2000).

Embora o conceito de discurso aponte para estruturas de reprodução social, ou seja, regularidades ou regras lingüisticas, que visam manter e reproduzir os discursos, o discurso não enfoca a não regularidade e a diversidade, no uso diário da linguagem pelas pessoas. Se procurarmos o sentido de um fenômeno (uma doença, por exemplo), não basta olhar os discursos produzidos, em relação a ele, mas também focalizar o sentido que esse fenômeno assume no cotidiano das pessoas, baseado na linguagem em uso. É através da ruptura com o habitual que o sentido se torna visível.

\begin{abstract}
"Discurso, linguagem social ou spe日ch genres são conceitos que focalizam, portanto, o habitual gerado pelos processos de institucionalização. O conceito de práticas discursivas remete, por sua vez, aos momentos de ressignificaçöes, de rupturas, de producäo de sentidos, ou seja, corresponde aos momentos ativos da linguagem, nos quais convivem tanto a ordem, como a diversidade. Podemos definir, assim, práticas discursivas como linguagem em ação, isto 6 , as maneiras a partir das quais as pessoas produzem sentidos $\theta$ se posicionam em relaçōes cotidianas" (SPINK 2000, p. 45).
\end{abstract}

As práticas discursivas têm, como elementos constitutivos, os enunciados (orientados por vozes), os gêneros da fala (speech genres) e os repertórios interpretativos (conteúdos). Os enunciados são expressões (palavras ou sentenças) articuladas em ações situadas, que articuladas à noção de vozes, adquirem caráter social (Bakhtin 1994, apud SPINK 2000). As vozes antecedem o enunciado e compreendem diálogos e negociações, que se processam na produção de um enunciado. Para Bakhtin, a linguagem, como prática social, tem, como pressuposto, que a pessoa não existe isoladamente $\theta$ os sentidos são construídos quando uma ou mais vozes, que podem estar, inclusive, temporalmente distanciadas, se confrontam. O pensamento é, portanto dialógico, pois os falantes e os ouvintes interagem mutuamente e orientam a produção de sentidos $e$ enunciados, fazendo com que a compreensão dos sentidos dependa do confronto de inúmeras vozes. 
Ao produzir um enunciado, o sujeito tem que se posicionar em relação a um sistema de linguagem e de enunciações preexistentes, posicionandose em relação a ele. O sentido, diz SPINK (2000) decorre do uso que o sujeito faz dos repertórios interpretativos de que dispõe. Os repertórios interpretativos são as unidades de construção das práticas discursivas, constituindo o conjunto de termos, descrições, lugares comuns e figuras de linguagem, tendo, como parâmetros, o contexto em que as práticas discursivas são produzidas e os estilos gramaticais específicos. Através dos repertórios interpretativos, podemos compreender, tanto a estabilidade como a variabilidade das produções lingüisticas humanas, o que nos leva a perceber a polissemia que caracteriza os discursos.

\begin{abstract}
"Admitir que as práticas discursivas são polissémicas, não significa, entretanto dizer que não há tendéncia à hegemonia ou que os sentidos produzidos possuem igual poder de provocar mudanças. Por outro lado, a natureza polissémica da linguagem possibilita às pessoas transitar por inúmeros contextos e vivenciar variadas situações" (SPINK 2000, p. 48).
\end{abstract}

A compreensão do processo de produção de sentido dependerá da busca dos elementos, com os quais eles são constituidos, ou seja, os repertórios interpretativos. Entretanto, o uso dos repertórios interpretativos nas práticas discursivas cotidianas nos leva a perceber que há uma implicação histórica, o que levou Spink a trabalhar em uma perspectiva temporal. O trabalho com o contexto histórico, na interface com o tempo, decorre do projeto de compreender as práticas discursivas institucionalizadas, na sua relação com as posições socialmente disponiveis e as estratégias lingüísticas de interação.

SPINK propõe que o processo de produção de sentido envolverá, portanto, a articulação de três dimensões temporais, historicamente contextualizadas: o tempo longo, o tempo vivido e o tempo curto. Essas dimensões temporais podem ser explicitadas da seguinte forma:

1- O contexto cultural ou tempo longo: constituido por diferentes domínios de saber, como a religião, filosofia, ciência, literatura e senso comum. Esses conteúdos de saber situam-se contextualizados historicamente, e se encontram no imaginário social, sendo acessados nas práticas sociais cotidianas, através de modelos, normas, convenções, entre outros.

2- O contexto social ou tempo vivido: são os conteúdos e significados adquiridos pelos sujeitos ao longo do processo de socialização primária e secundária, na medida em que eles são inseridos em grupos sociais específicos (estratos sociais, grupos profissionais, etc) e correspondem às experiências dos sujeitos no curso de sua história pessoal. Essa dimensão temporal relaciona-se com a concepção bakhtiana de aprendizagem de linguagens sociais, em que o sujeito 
aprende discursos peculiares a determinados estratos, numa determinada sociedade, em um contexto histórico específico.

3- O contexto interacional ou tempo do aqui-agora: conteúdos do tempo presente nas relações interacionais, face-a-face do cotidiano. Trata-se da dimensão micro das escalas de interação, marcada pelos processos dialógicos (aqueles que permitem compreender a dinâmica da produção de sentidos).

A abordagem da produção de sentidos opera, portanto, na interface dos três tempos históricos: entre a construção social dos conteúdos culturais do tempo longo; as linguagens sociais que aprendemos no tempo vivido e os processos dialógicos de tempo curto (SPINK 2000). Os repertórios são continuamente ativados e reconstruidos, em funçāo do contexto sóciohistórico, o que nos permite verificar que as produçōes dos vários domínios de saber, entre eles, o campo da ciência, promovem contínuas ressignificações de seus conteúdos.

A postura construcionista não pretende fazer uma apologia de um método que possibilite traduzir os fatos como são, pois nessa abordagem, os fatos são tomados como construções sociais, versões de mundo que podem assumir maior ou menor poder performático, dependendo do contexto de produção, do momento histórico e das relações sociais. Alia-se, portanto, à tradição hermenêutica de processo criativo, mediado pelas expectativas e pressupostos que a pessoa traz para a situação, valorizando a presença do outro e à onipresença da linguagem, na perspectiva das práticas discursivas (SPINK 2000).

SPINK e LIMA (2000) explicitam a interpretação como um processo de produção de sentidos, ou seja, como um produto circular e inacabado. $O$ sentido é o meio e o fim da tarefa da pesquisa, e a interpretação emerge como elemento intrínseco do processo de pesquisa, não havendo distinção entre o momento de levantamento das informações e o momento da interpretação. Isso significa que durante todo o percurso da pesquisa, 0 pesquisador se encontra imerso no processo de interpretação. Pode haver um confronto entre os sentidos construídos no processo de pesquisa e de interpretação em relação aos sentidos decorrentes da familiarização prévia com o campo de estudo (na pesquisa bibliográfica, por exemplo), bem como as teorias de base.

"É desse confronto inicial que emergem nossas categorias de análise. Buscamos então, analisar o material que temos a nosso dispor (entrevistas, discussōes de grupos, textos, etc) a partir dessas categorias. Mas não apenas os conteúdos que nos interessam. Para fazer aflorar os sentidos, precisamos entender, também o uso feito desses conteúdos" (SPINK e LIMA 2000 in SPINK 2000, p. 106)

Um dos objetivos deste trabalho foi compreender o sentido que mulheres, vivendo com HIV/Aids, constroem para a gravidez e a maternidade. A construção desse sentido, segundo a perspectiva 
construcionista, relaciona-se com vários repertórios presentes nas práticas discursivas das mulheres e da equipe multiprofissional. Esses repertórios circulam na interação entre os sujeitos e se expressam em seus discursos, produzindo campos de saber e de poder. Os sentidos produzidos não deixam de influenciar as subjetividades ali envolvidas. Nosso trabalho de análise de produção de sentidos não poderia, portanto, deixar de levar em conta a interface dos repertórios sobre maternidade e HIVIAids no discurso das mulheres entrevistadas, em relação aos discursos de saber das diversas áreas da saúde.

Quanto à análise, que se refere ao prisma psicanalítico, o campo que lida com o sem sentido, bem como para além do sentido do discurso, tomamos a contribuição do texto de Zizek (1992), que aponta as relações entre desejo e ideologia política, articulado à proposta lacaniana de abordar a questão do desejo, a partir do matema lógico do "grafo do desejo" (LACAN 1998). No que concerne a esse prisma, pudemos também reconhecer os elementos do discurso que se relacionam com os conceitos de identificação imaginária [i(a)] e identificação simbólica $[\mathrm{I}(\mathrm{A})]$. As entrevistas foram analisadas, também, com intuito de apontar para uma articulação com os elementos ligados aos núcleos de gozo, ou seja, às formaçōes fantasísticas e à posição dos sujeitos perante seu desejo inconsciente. $\dot{E}$ evidente que, no nível da análise dos núcleos de gozo, é, metodologicamente, adequado um posicionamento psicanalítico stricto sensu, ou seja, alicerçado na técnica analitica, e por isso, em nossa proposta de trabalho, buscamos preparar um campo de investigação possivel. Ao apontar que há, no sujeito, um "para além do sujeito", procuramos mostrar que o trabalho psicanalítico pode trazer uma contribuição para avançar na abordagem do fenômeno estudado.

\section{2 - Desenho do estudo}

Foram entrevistadas quinze mulheres adultas (maiores de 18 anos) diagnosticadas como portadoras do HIV, grávidas, ou que tiveram filhos após a descoberta da infecção pelo HIV. Os sujeitos da pesquisa foram selecionados, independentemente de seu estadiamento clínico e condição sócio-econômica. $O$ número de entrevistadas foi determinado, seguindo a referência de BARDIN (1977), que apontou o número de 15 entrevistas, como capaz de reter conteúdo significativo, para análises qualitativas.

\section{3 - Critérios para seleção de sujeitos da pesquisa}

Do total de entrevistadas, sete são mulheres freqüentadoras da Associação de Voluntários no Apoio aos portadores de Aids (Avaids), localizada na cidade de São Paulo, e as demais, freqüentadoras do Instituto de Infectologia Emílio Ribas, também localizado na cidade de São Paulo. Os comprovantes de autorização dessas instituições, para realização da pesquisa, estāo em Anexo I. 
A Avaids é uma organização não-governamental, que presta serviços de apoio psicológico, jurídico e de assistência social a portadores do HIV. As mulheres entrevistadas são freqüentadoras de reuniões quinzenais, conduzidas por uma psicóloga e uma assistente social, nas quais recebem acompanhamento Psicológico, além de doação de leite (Nan 1 e Nan2) e cestas básicas. $O$ recebimento do leite $\Theta$ das cestas básicas está condicionado à presença nas reuniōes quinzenais e à prestação de serviços gerais na instituição, por um dia, em cada mês (limpeza geral, atendimento de telefone, organização de arquivos, organização de bazares, entre outros).

As mulheres entrevistadas no Instituto de Infectologia Emílio Ribas são acompanhadas, clinicamente, em regime ambulatorial, por Dra. Carla Vasquez, médica infectologista da instituição. O Instituto Emílio Ribas é um hospital público (SUS), do governo do Estado de São Paulo, especializado no diagnóstico, tratamento e seguimento de pacientes com doenças infecciosas e parasitárias.

As entrevistadas foram convidadas a participarem da pesquisa $e$ assinaram um "Termo de consentimento livre e esclarecido". A entrevista foi gravada, com autorizaçāo explicita, de cada entrevistada. O tempo médio das entrevistas foi de, aproximadamente, 50 minutos (um encontro) e, quando se fez necessário, houve dois encontros.

\section{4 - Levantamento dos dados}

$O$ instrumento usado foi um roteiro temático, com questões abertas e questōes de caracterização sócio-demográfica, bem como clínicoepidemiológica (anexo II). As entrevistas foram gravadas, utilizando um gravador de pequeno porte (GE modelo 3-5385a).

As freqüentadoras da Avaids, que estavam de acordo com os critérios propostos, foram abordadas diretamente, ou por telefone, pela pesquisadora, e as entrevistas foram agendadas e realizadas, individualmente, no próprio local (Avaids), preferencialmente no dia da reunião quinzenal. No caso das entrevistas realizadas no Instituto de Infectologia Emílio Ribas, o convite foi, inicialmente, proposto pela médica infectologista, que acompanha clinicamente as mães $\theta$, depois, mediante manifestação de seu interesse em participar da pesquisa, as mulheres foram encaminhadas para a entrevista com a pesquisadora, em uma sala apropriada.

\section{5 - Tratamento dos dados}

As entrevistas foram transcritas, permitindo uma primeira aproximação dos dados obtidos, além de uma escuta cuidadosa dos aspectos, que não foram apreciados, imediatamente, durante a entrevista. Foi elaborada uma ficha síntese de caracterização de cada um dos sujeitos da pesquisa. Essa ficha contém os dados sócio-demográficos, condições de 
assistência, condição sorológica e anticoncepção. O objetivo dessa ficha foi permitir uma aproximação facilitada dos dados das entrevistadas, dando contexto às falas a serem relatadas no processo de análise dos discursos.

Após a transcriçāo, as entrevistas foram lidas, assinalando-se os temas recorrentes, para estabelecimento de categorias gerais e específicas de análise. Estabelecemos, também, para cada uma das entrevistas, um diagrama, chamado "Linha narrativa" (SPINK e LIMA 2000; Castro 2001), que visou permitir, ao leitor, acesso às informaçōes, situadas de forma linear e/ou cronológica. A partir disso, os dados foram analisados, segundo a análise de produção de sentido, e a partir do prisma Psicanalítico.

A seguir, é apresentado um quadro-resumo das convençōes utilizadas na transcrição das entrevistas.

Figura 6 - Quadro de convençōes utilizadas na transcrição das entrevistas.

\begin{tabular}{|c|c|}
\hline Convençōes & Significados \\
\hline$\cdots$ & $\begin{array}{c}\text { Pausas, silêncios prolongados ou interrupções no } \\
\text { discurso }\end{array}$ \\
\hline $\mathbf{E}$ & Entrevistadora \\
\hline $\mathrm{R} / \mathrm{A} / \mathrm{F} / \mathrm{M} / \mathrm{B} / \mathrm{D} / \mathrm{S} / \mathrm{C}$ & Iniciais dos nomes das entrevistadas \\
\hline$(1)$ & $\begin{array}{c}\text { Comentários da entrevistadora sobre aspectos não } \\
\text { verbais da entrevista }\end{array}$ \\
\hline (...) & Interrupção do trecho transcrito \\
\hline
\end{tabular}

\section{6 - Aspectos Éticos}

Os sujeitos da pesquisa assinaram um "Termo de Consentimento Livre e Esclarecido" (Anexo III), por meio do qual receberam informaçōes sobre a natureza e a finalidade da pesquisa. Mediante sua autorização, receberam uma cópia desse termo de consentimento.

A resolução do Conselho Nacional de Saúde do Ministério da Saúde CNS196 de 10/10/96, sobre pesquisas com seres humanos, determina que devemos zelar por quatro requisitos básicos: sigilo; riscos e benefícios; voluntariedade e consentimento livre e esclarecido.

Neste trabalho, respeitamos, fielmente, esses preceitos, garantindo o sigilo (não identificação do entrevistado), voluntariedade (podendo encerrar o processo em qualquer momento desejado) e acesso ao termo de Consentimento Livre e esclarecido (Anexo III). Quanto ao risco de pesquisa, na medida em que não utilizamos qualquer procedimento invasivo, o mesmo não se aplicou.

Serão destruidas todas as anotações do trabalho de campo, que possam permitir a identificação das participantes, embora os nomes das 
entrevistadas sejam fictícios. As fitas gravadas serāo mantidas pela pesquisadora, em local seguro, por cinco anos, após os quais, serão, também, destruidas. Todos os dados obtidos foram utilizados, exclusivamente, para o propósito desta pesquisa. 


\section{Capítulo VI - Caracterização das mulheres entrevistadas.}

As mulheres entrevistadas tinham entre 18 e 37 anos de idade (média de 27 anos), a maioria afirmou se encontrar em "união estável" (60\% das entrevistadas), sendo que nenhuma das entrevistadas declarou ter se casado, oficialmente. Apenas $13 \%$ das entrevistadas afirmaram que seu atual relacionamento tinha menos de 12 meses, sendo que a maioria declarou um tempo de relacionamento entre um e cinco anos. A maior parte das entrevistadas é natural da regiāo sudeste $(67 \%)$, predominando, em termos de escolaridade, o primeiro grau incompleto (40\%). Cerca de $40 \%$ das entrevistadas não sabia informar o grau de escolaridade do parceiro.

Quanto à renda pessoal, $33 \%$ das entrevistadas afirmaram que não tinha qualquer renda, e $33 \%$ informaram ter uma renda entre um e três salários mínimos. Apenas uma das entrevistadas declarou ter formação escolar superior e exercer uma função, que exige maior qualificação profissional (bancária). As demais entrevistadas declararam trabalhar em casa, ou em profissões que não exigem qualificação profissional.

O parceiro, em $47 \%$ dos casos, é também soropositivo, sendo que $33 \%$ referiram que seu parceiro desconhece seu estado sorológico, ou não fez o exame, até o momento da entrevista. Quatro das entrevistadas (27\%) relataram que 0 namorado/companheiro falecera, em função de complicaçōes decorrentes do HIV.

A maioria das entrevistadas $(80 \%)$ conhece sua situação sorológica há mais de três anos, sendo que $60 \%$ delas iniciaram o tratamento há, pelo menos, três anos.

A maioria relatou que a forma de infecção foi no contato sexual, com um companheiro ou namorado $(93 \%)$, sendo que apenas uma das entrevistadas atribuiu a infecção a uma transfusão sanguínea, durante uma de suas gestações. Quanto ao uso de substâncias licitas e ilicitas, $33 \%$ das entrevistadas afirmaram já ter feito uso abusivo de drogas (álcool, maconha ou crack), sendo que apenas duas das entrevistadas informaram que seu companheiro era usuário de drogas injetáveis.

Quanto ao número de filhos, duas das entrevistadas estavam grávidas; a maioria tinha mais de um filho ( $67 \%$ das entrevistadas) e uma das entrevistadas declarou que um de seus filhos faleceu, aos quatro meses de idade, em conseqüência de um quadro de Aids. A maior parte das entrevistadas $(60 \%)$ não descobriu o HIV, enquanto estavam grávidas (souberam de sua situação sorológica antes da gravidez, ou entre uma gravidez e outra). Cinco das entrevistadas (33\%) descobriram o HIV antes de engravidarem, e engravidaram, posteriormente, decidindo levar a gravidez adiante. Algumas entrevistadas $(27 \%)$ já tinham filhos, sabiam-se portadoras do HIV e decidiram ter outro(s) filho(s). Algumas entrevistadas tiveram filhos soropositivos (20\%), sendo que a maioria $(73 \%)$ teve acesso à 
prevenção da TMl, em todas as gravidezes (a entrevistada, que está grávida, já iniciou o acompanhamento para prevenção da TMI).

A maioria das entrevistadas afirmou que não faz uso consistente de preservativos $(67 \%)$, sendo que destas, apenas $20 \%$ adotaram esse comportamento, em função de terem decidido engravidar. Algumas entrevistadas $(20 \%)$ afirmaram que engravidaram "por que o preservativo estourou" e duas entrevistadas (13\%) relataram ter ciência de que engravidaram, em função do uso esporádico de preservativo nas relações sexuais.

No Anexo IV, é possível consultar um quadro resumo, com os principais dados sócio-demográficos das participantes do estudo, e que foram expostos, acima.

\section{1 - Apresentação das mulheres entrevistadas}

Nesse âmbito da análise, apresentamos as entrevistas, destacando os pontos principais para a construção do sentido. Ao final de cada entrevista, apresentamos comentários, que visam construir um sentido da questão da gravidez e maternidade, para a entrevistada. Apontamos, também, aspectos, em que foi possível vislumbrar questōes inconscientes, ou mesmo, a posição que a entrevistada assume, em relação ao desejo inconsciente.

A título ilustrativo, no início de cada entrevista, apresentamos um diagrama construído, denominado "Linha narrativa" (SPINK e LIMA 2000; Castro 2001). Esse diagrama permite que o leitor tenha acesso às informaçōes, situadas, de forma linear, com 0 intuito de facilitar a compreensão da entrevista, pois o discurso espontåneo, obtido nas entrevistas, nem sempre é linear, e/ou cronologicamente situado. Para melhor compreensão desse diagrama, sugerimos que o leitor adote a seguinte ordem de leitura: da esquerda para a direita e do centro para cima ou para baixo. $O$ lado superior do quadro diz respeito aos eventos ligados à gravidez e nascimento do(s) filho(s). No lado inferior, situaremos alguns dos eventos significativos do cotidiano da entrevistada. A figura abaixo ilustra esse procedimento:

Figura 7- Diagrama explicativo para leitura das "Linhas Narrativas"

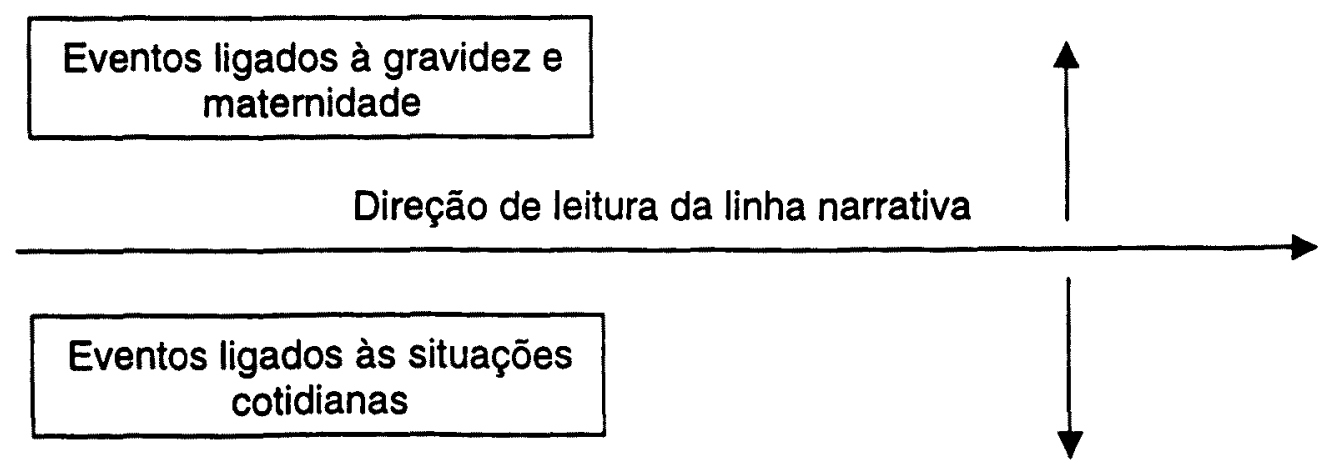


6.1.1 - Rita: que se sente culpada por ter engravidado quando já sabia que tinha o HIV.

Síntese: Ela tem 18 anos, dois filhos (uma menina de 2 anos, HIV-e uma menina de 11 meses, HIV-). É dona de casa e estudou até a quarta série do primeiro grau. Descobriu o HIV durante a primeira gravidez, no quinto mês de gestação. Seu companheiro é HIV negativo e ela supõe ter contraído HIV em um relacionamento anterior. $O$ casal faz uso esporádico de preservativo masculino, sem se preocupar com o risco de infecção do parceiro e não adota outro método contraceptivo.

Figura 8 - Diagrama da linha narrativa relativa à entrevistada Rita

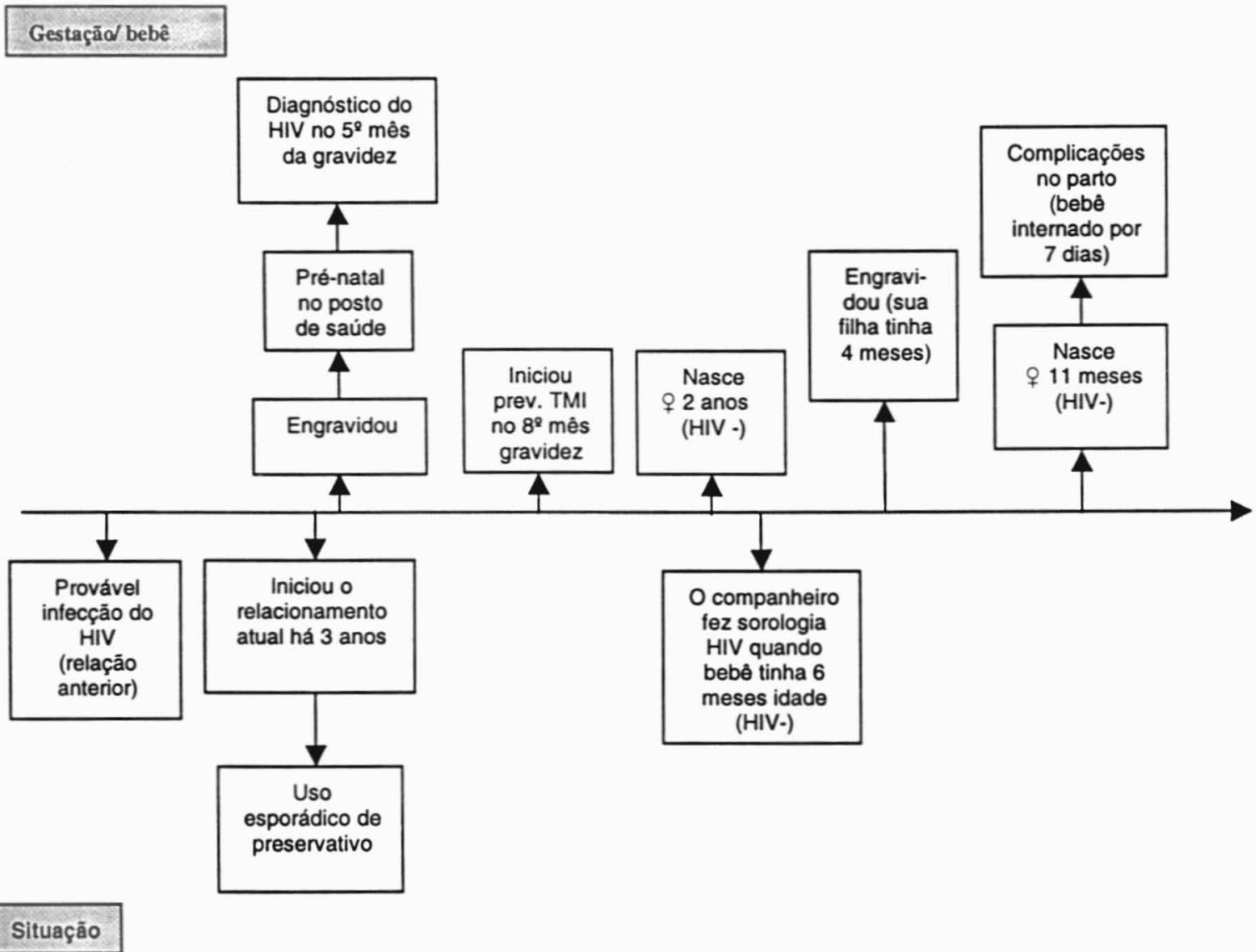

Com 16 anos de idade, Rita descobriu que estava grávida, quando foi fazer seu pré-natal no posto de saúde, perto de sua casa, e no quinto mês de gravidez, soube que era soropositiva. Foi encaminhada para acompanhamento no Instituto de Infectologia Emílio Ribas. O pré-natal passou a ser no Hospital Cachoeirinha, onde Rita e seu marido foram atendidos pela equipe da psicologia. Quando soube da notícia, Rita reagiu pensando que iria morrer imediatamente, bem como seu bebê. "Ah, foi horrível, né? Eu já imaginei que a nenê ia morrer também" (p. 2). 
Seis meses após o nascimento de sua primeira filha, seu companheiro fez a sorologia para HIV e constatou que era soronegativo. O casal não conversou sobre o assunto, pois Rita sentiu "medo de ser rejeitada".

Quando sua primeira filha estava com quatro meses de idade, ela engravidou novamente. Rita comentou que a situação da primeira, para a segunda gravidez foi diferente, pois enquanto a primeira foi "desejada", a segunda foi "um acidente".

"E: Pelo que ou entendi, vocé teve a A., não é? E logo depois vocé ficou grávida da $V$.. Entāo você teve relações sexuais sem preservativo, não é? $R: E$.

E: Se não, não teria ficado grávida. Como é isso?

R: Ah, isso al... (risos). Ah, o marido, né? Ele não liga" ( p. 6).

(...)

"E: (...) Como está pra você pensar como está a situação do HIV para elas?

Como é para vocé imaginar que talvez seus bebés fossem infectados?

R: Ah, difícil, porque, tipo assim, você se sente culpada, né? Eu sei que não tem nada a ver, mas sei lá. Eu me senti culpada.

E: Culpada. Culpada de que?

R: Ah, sei lá. De ter pegado e de ter ficado grávida, porque se eu soubesse eu não ia querer ter ficado grávida. Acho que por isso. Eu não ia ter ficado grávida, mas eu não sabia, né? Mas dela (primeira gravidez) fol porque quis. Da outra (segunda gravidez) fol um acidente.

E: Foi um acidente?

R: Foi né?

E: Como acontece um acidente assim?

R: Foi assim, a camisinha estourou, porque eu não sabia da pliula do dia seguinte. Al veio a $V^{\prime \prime}$ (p. 6).

A preocupação com a possibilidade de que Rita venha a adoecer foi explicitada. O casal mantém relações sexuais, sem uso sistemático de preservativos, o que leva ao risco de infecção do parceiro. Rita teme que se o parceiro for infectado, ele também possa adoecer e suas filhas corram o risco de não ter mais quem possa cuidar delas.

"E: É bom ser mãe?

R: Ébom.

$E$ : Interessante é que parece que vocé ficou triste...

R: Mas seria mais se eu não tivesse HIV, seria melhor. Seria melhor se eu näo precisasse ficar doente. Se eu chegar a ficar doente assim, eu penso nelas, assim. $O$ que eu vou fazer com elas?" ( $p .7$ ).

(...)

"R: Eu me preocupo com isso, porque assim, às vezes eu penso, ele não tem (HIV) e então é mais fácil ele cuidar delas. Só que às vezes a gente vai sem camisinha, né? E se ele pegar e ficar doente também o aí? o que val ser delas, né? Eu falo pra ele. Tem que usar pensando nelas porque e aí se vocé pega e fica doente também? Se nós dois..., quem val cuidar delas, né?"( p. 7).

O relato de Rita mostrou que há uma contradição entre discurso (o falar) e comportamento (o agir). Ela afirmou que a primeira gravidez foi "desejada" e quanto a isso, não se sente "culpada", entretanto, a segunda gravidez foi um 
"acidente", que gera culpa. Podemos nos perguntar o por quê disto, se considerarmos que a responsabilidade por um "acidente" não é algo que, sob o ponto de vista da consciência, possa gerar a responsabilização do sujeito. Embora ela afirme que se sente culpada por ter engravidado novamente, sabendo que era soropositiva, o casal mantém comportamento de risco (relaçōes sem preservativo) de infecção do parceiro, e de engravidar. Mas o uso esporádico de preservativo no relacionamento do casal pode indicar que há um pacto silencioso, que gera conseqüências.

Essa entrevista não permite definir qual é a questão inconsciente relacionada ao comportamento do casal, entretanto, é possível ver nos binômios "filho desejado/ filho do acidente"; "comportamento de risco/medo de adoecer"; e por fim "engravidar/ sentir culpa", uma série de contradiçōes, que indica que há um sujeito que atualiza suas questões inconscientes no comportamento, e sem reflexão. Embora Rita declare se sentir culpada, ela não parece responsabilizar-se por suas escolhas, nāo sendo capaz de se responsabilizar pelo que the é inexorável, ou seja, seu inconsciente. Nesse sentido, um trabalho analítico poderia levá-la a se posicionar perante seu desejo inconsciente e, assim, poder deparar-se com sua condição de sujeito desejante. 


\subsection{2 - Ângela: que teve trigêmeas, e "ainda não caiu a ficha"}

Síntese: Aos 33 anos, vive, em união estável, há um ano e meio, e seu companheiro não fez exames para saber se tem HIV. Ela conhece sua situação sorológica há cinco anos. Bancária de profissão, estudou até completar o segundo grau. Teve trigêmeas, que agora estão com 3 meses de idade. Logo após o parto, em função de uma grave hemorragia, precisou fazer uma histerectomia. Com três bebês pequenos, e por ter estado "à beira da morte", Ângela manifesta que ser soropositiva é um problema menor, comparado a outras preocupações.

Figura 9 - Diagrama da linha narrativa relativa à entrevistada Ângela

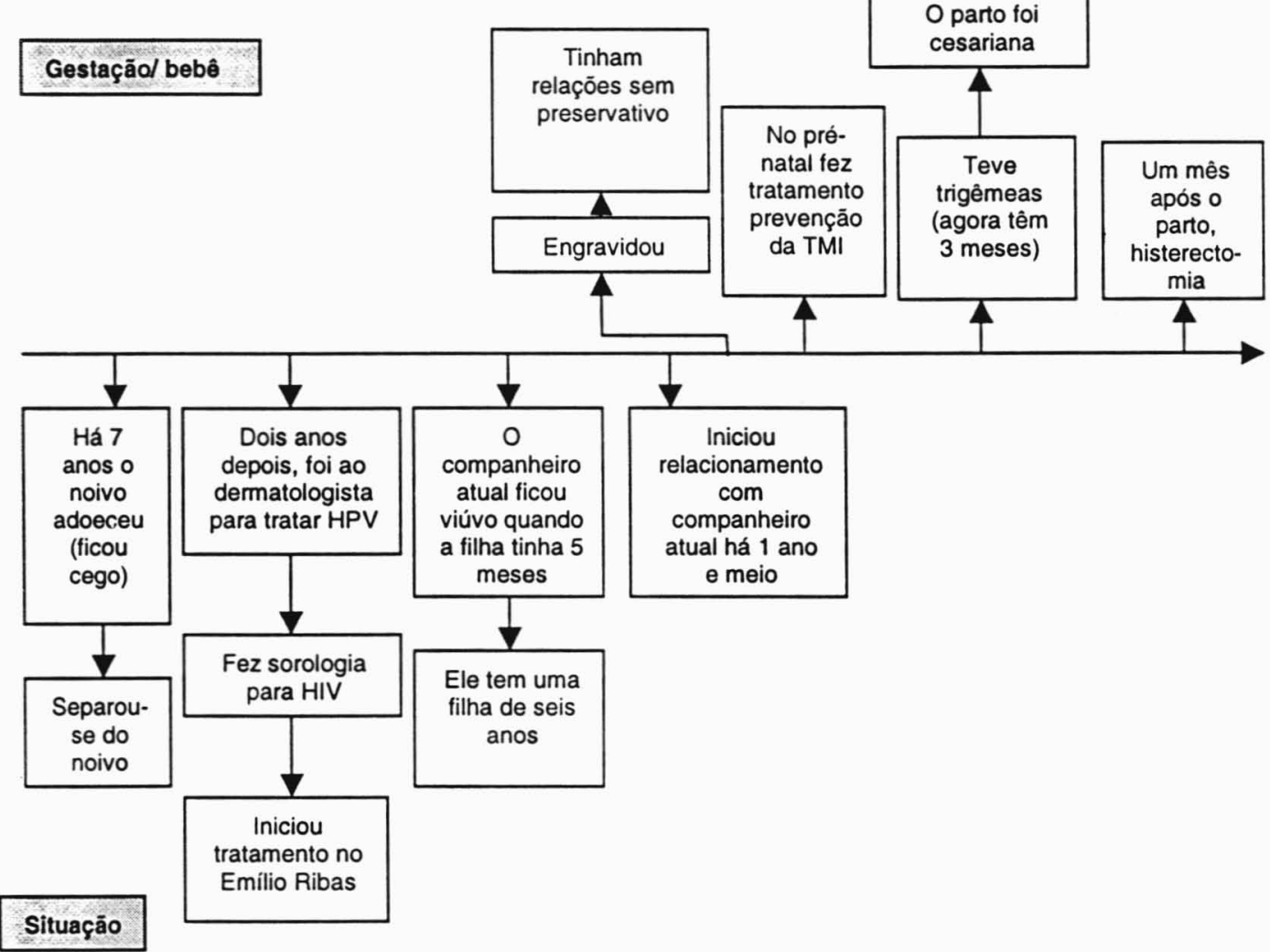

Ângela foi noiva de uma pessoa, que adoeceu e ficou cega. Ele foi diagnosticado com HIV, mas ela não foi fazer o teste. O casal se separou, em função de outras questões, não relacionadas com o HIV. Dois anos depois, ela foi ao médico dermatologista, que detectou "verrugas genitais" e pediu a sorologia para HIV, constatando a infecção. Sobre a decisão de ter um filho, ela comentou: 


\begin{abstract}
"A: Quando eu era noiva eu tinha sonhos de ter filhos, depois ai eu fiquei sabendo que eu era infértil e eu perdi a vontade de ser mãe depois, né? Só que eu não encontrava a pessoa...

E: Vocé abriu mão desse sonho?

A: (pausa) Eu não ia encontrar uma pessoa que me acompanhasse. Eu pensei até em ser mãe solteira durante uma época. Depois pensei, não, isso não está certo, porque é um ser vivo, uma criança. Ele vai cobrar um pai, alguma coisa, né? E agora que eu sou mãe que eu vejo que precisa ter pai. Se eu não tivesse - meu marido junto comigo, eu não sei o que eu faria. Então depois que eu conheci essa outra pessoa eu não pensava mais em ter filhos. Só que Deus fol muito bom porque na hora de mandar os filhos, mandou também uma pessoa que ficasse comigo" (p. 12).
\end{abstract}

Ela mantém um relacionamento, há pouco mais de um ano, com um homem e é viúvo e que tem uma filha, com seis anos de idade, fruto do primeiro casamento. Ele já sabia que Ângela é soropositiva e, até o momento, não fez o teste para HIV. Eles decidiram ter relaçōes sexuais, sem preservativo, e, depois de alguns meses de namoro, ela engravidou.

"E: Então vocês tinham um relacionamento intimo, mas não rolava camisinha porque ele dizia que não...

A: Ele não se importava, ele gostava de mim do mesmo jeito e não se importava com isso. (...)Ai eu fiquei grávida e nem sabia que eu tinha ficado grávida, sempre fazia minha consulta rotineira com o ginecologista, meus exames e ela falou assim, eu não vou fazer exame em você porque você está grávida. Como que pode eu grávida? Mas vocé está, ela falou. Al tinha que confirmar, mas ela falou, eu não sou obstetra, sou ginecologista. Dal fui fazer os exames que eram ultra-som e dal confirmou que eu estava no primeiro mês. Fiquel sabendo que estava grávida de três (bebês) no primeiro mês já. E: Mas como foi isso?

A: Ah, na hora eu fiquei nervosa pensando em como eu ia cuidar das crianças, não assim pelo... Pensei em outras coisas. Como é que eu vou fazer para cuidar das crianças. Mas meu marido ficou contente. (...)" (p. 4).

$\mathrm{Na}$ época da entrevista, suas filhas estavam com três meses de vida e, ainda sob o impacto da notícia, ela relatou que não "caiu a ficha". Ela tem grande preocupação com a situação das filhas, quando sua licença terminar e precisar retornar ao trabalho.

"E: Interessante porque vocé está falando e parece que vocé está ainda sob o impacto.

A: $\dot{E}$, não caiu a minha ficha para falar a verdade (risos). Durante uma época eu queria tanto ser mãe e depois que eu fiquei, eu não sei, meio esquisito. Eu não sei explicar, parece que eu estou meio boiando, assim. Não sei se é porque eu estou trabalhando muito porque é trés, talvez se fosse uma, talvez eu estivesse sentindo mais. Eu não sei explicar. Mas como tem três e eu estou trabalhando muito, então tem uma rotina, assim." (p. 4-5)

(...)

"E: (...)Como é que foi para vocé ser portadora do HIV $\theta$ se descobrir grávida?

A: Não pensei. Não sei se porque eu estava fazendo tratamento, não tenho nenhuma seqüela, então para mim é uma vida normal, só que eu não conto pra ninguém, só para minha mãe e meu marido. Mais ninguém sabe.

E: Só sua mãe?

A: E meu marido, mais ninguém sabe. Eu tenho uma irmã, minha tias, ninguém sabe. Nem da família dele, ninguém sabe" (p. 6). 
Quando suas filhas completaram um mês, ela precisou ser internada para a realização de uma histerectomia, de urgência. Ela pensou que fosse morrer e seu marido, que já tinha vivido a experiência de perder uma esposa, pensou que fosse ficar viúvo, novamente.
"E: Ângela, como é que você está?
A: (risos) Olha, nem eu seil
E: Aquela correria com os bebês e depois de um mês você passa por uma outra cirurgia.
A: Ainda teve a cesárea e eu fiquei uma semana no hospital por que teve a hemorragia. Cheguei desmaiada no hospital, perdi muito sangue. Da última vez eu achei que ia morrer, que não ia mais voltar do hospital. Antes da cirurgia já me despedi, eu falei não vou voltar. Eu tava muito fraca, muito, muito mesmo. Quando eu voltei da anestesia eu pensei "ai, meu Deus do céu, será que eu acordei no céu?". Eu falei, doutor, eu acordeil Ele falou, não é à toa, é esperado, né? (...) Meu marido já era viúvo e ele ficou morrendo de medo de ficar viuvo de novo. Olha, eu tenho um companheiro muito forte do meu lado, muito bom, viu?" (p.7)

Depois de tudo o que aconteceu, ser mãe tem sido exaustivo e difícil, não permitindo que ela pense em qualquer outra coisa, que não seja a manutenção da rotina de cuidados das filhas.
"A: Ah, eu acho que (ter filhos) tem uma relação de carinho, mas não sei. Acho que não caiu a minha ficha, para falar a verdade. Acho que ainda não tenho aquela relação de falar "ah, meu filho é minha vida". Acho que tem muita mãe que vai falar assim. Mas eu não sei... É Iógico, eu tenho um amor pela criança, mas eu estou trabalhando tanto que não tenho tempo para essas coisas.
E: É como se vocé tivesse que estar ligada no automático para poder dar conta de tudo?
A: Eu acho que vai cair a minha ficha quando eu voltar a trabalhar, acho que eu vou começar a chorar. Porque eu sou muito chorona, né? Acho que quando eu começar a trabalhar, deixar as crianças lá no berçário, na mão de outras pessoas, vai ficar difficil. Não é mãel Não é parente, não é a avó. Ai eu vou sentir. Al vai cair a minha ficha e eu vou começar a chorar todo dia, eu acho."
(...)
"E: Para você ser mãe e portadora do HIV, não teve muita influéncia?
A: Pra mim não teve nenhum problema.
E: Não teve nenhum problema ser portadora do HIV?
A: Pra mim, eu nem lembro. Só quando eu tenho que tomar remédio.
E: Então, o difícil tem sido você se adaptar ser mãe de três.
A: Você entendeu o que eu quis dizer. Não que eu não goste de ser mãe, não é issol Até eu aprender tudo, é demais" (p. 9-10).

Ângela acredita que a diferença entre a gravidez de uma mulher soropositiva e a de outra, que não tem o HIV, diz respeito apenas ao risco de transmissäo, que, para ela, estaria diretamente associado à carga viral da mulher.

É interessante notar que, até o momento, segundo seu relato, seus filhos não fizeram nenhuma sorologia para HIV. Quando a entrevistadora perguntou, diretamente, sobre a possibilidade de que as crianças tenham o vírus, a atitude da entrevistada mudou, abruptamente: ela passou a responder de forma 
incisiva, interrompendo, várias vezes, a entrevistadora. Perguntas que envolviam sua percepção sobre o olhar do outro, perante suas decisões, ou que diziam respeito às perspectivas de futuro, também implicaram respostas incisivas.

"E: E para os seus filhos, vocé acha que tem conseqüência você ser portadora do HIV e decidir ter um filho? Você acha que um dia, quando ele crescer...(ela interrompeu a entrevistadora)

A: Eu já pensei nisso também.

E: Você acha que vão sentir (ela interrompeu a entrevistadora)

A: As vezes eu penso que se algum deles tiver o HIV e me culparem por saber que eu tinha o problema e ter filho assim mesmo. A única coisa que eu penso do futuro assim. No momento eu não... Pra mim não tem nenhum problema de eu ser mãe e ter tido filhos, não é problema. Só penso se algum deles tiver algum problema e eles me acusarem no futuro.

E: Vocé sente que é uma decisão que vocé poderia ter tido, no sentido de alguém te acusar, alguém te culpar? Acha que tem alguma coisa nesse sentido?

A: (pausa) Não.

E: De teus filhos olharem para vocé e falarem, nossa...

A: Não sei qual vai ser o futuro, vocé nunca pode esperar a reação das pessoas. Não sei como vai ser. Pode ser que alguma tenha o virus e alguém... Pode ficar revoltada. Eu não posso...

$E$ : Mas e você... (ela interrompeu a entrevistadora)

A: Eu não posso...

E: E se elas não tiverem. Mas ter uma mãe que é portadora do HIV, você acha que influencia?

A: Eu não sei como elas vão pensarl Não sei, eu não sei responder essa pergunta, eu não sei como vai ser o futuro" (p. 8).

Ângela reconhece que o momento que vive tem uma "tônica" muito especial, que faz com que, diante de tantas dificuldades, seu comportamento esteja alterado. Ela reconhece que há momentos em que tem dificuldades de escutar ao outro, chegando, mesmo, a deixar de levar em conta informaçōes importantes, como o horário de medicação das crianças.

"E: $E$ os bebês?

A: Os bebés tomaram o xarope, aliás, eu estava dando até hoje e a médica falou que era para suspender $e$ eu não sabia. Ela já tinha falado, mas eu não tinha prestado atenção. Meu marido falou, Ângela, é sei semanas para dar. Já faz trés meses que eu estou dando e a médica falou não é para dar mais não. E ele vem comigo nas consultas, ele ficava prestando atenção, ele é muito atencioso, e eu não escutava direito" (p. 6).

Depois de colocar em segundo plano a possibilidade de ter um filho, houve uma retomada dessa questão, em um novo relacionamento. Para Ângela, a maternidade parece implicar poder contar com um companheiro, que the garanta apoio incondicional. Ela explicita, ainda, sua preocupação com o retorno ao trabalho. Embora essa preocupação esteja voltada para uma questão de ordem prática, não podemos deixar de notar que há grande angústia envolvida, pois, ao mesmo tempo em que ela tem dificuldades de ficar "o dia todo, trancada em casa, cuidando das filhas", ela também teme o momento de "sair para trabalhar". Essa situação cria um paradoxo de difícil 
solução, fazendo com que, afinal, ela não possa se situar em "lugar algum", e, ao mesmo tempo, sendo exigida "em lugares distintos".

Tanta angústia mobilizando mecanismos de defesa, parece ter feito com que ela não pudesse dar um sentido para o fato de ter-se tornado mãe. Ainda não foi possível descobrir o que há de específico na relação com suas filhas. Por outro lado, tanto trabalho e tantas dificuldades propiciaram uma certa "proteção", na medida em que ela não tem como parar, para pensar no HIV "Não dá nem tempo de pensar que tem HIV.".

Ângela interrompeu, várias vezes, a entrevistadora, principalmente, quando o assunto visava aspectos sobre o futuro, suas perspectivas com relação à percepção de suas filhas e da sociedade, a respeito de suas decisões. Ela parece querer mostrar que "tudo está bem", mas acaba por deixar perceber que há o risco iminente de que a angústia, sob a forma do retorno do recalcado, faça-se presente. Não poder "situar-se em um lugar confortável", não poder escutar... São comportamentos que visam proteger contra a angústia, mas que trazem conseqüências, em longo prazo. Como ela mesma disse, "não caiu a ficha", mas o que vai acontecer quando cair? 
6.1.3 - Ana Carolina: que via todo mundo querendo ter um filho e não queria se diferente

Síntese: Tem 30 anos e é separada. O diagnóstico do HIV ocorreu no $6^{\circ}$ mês de gestação. Seu companheiro é soronegativo e, após a descoberta do HIV, o casal se separou. Seu filho tem, agora, 3 anos (HIV-) e eles moram na casa dos sogros. Ela afirmou que não quer mais ter filhos, em função de ser soropositiva.

Figura 10 - Diagrama da linha narrativa relativa à entrevistada Ana Carolina

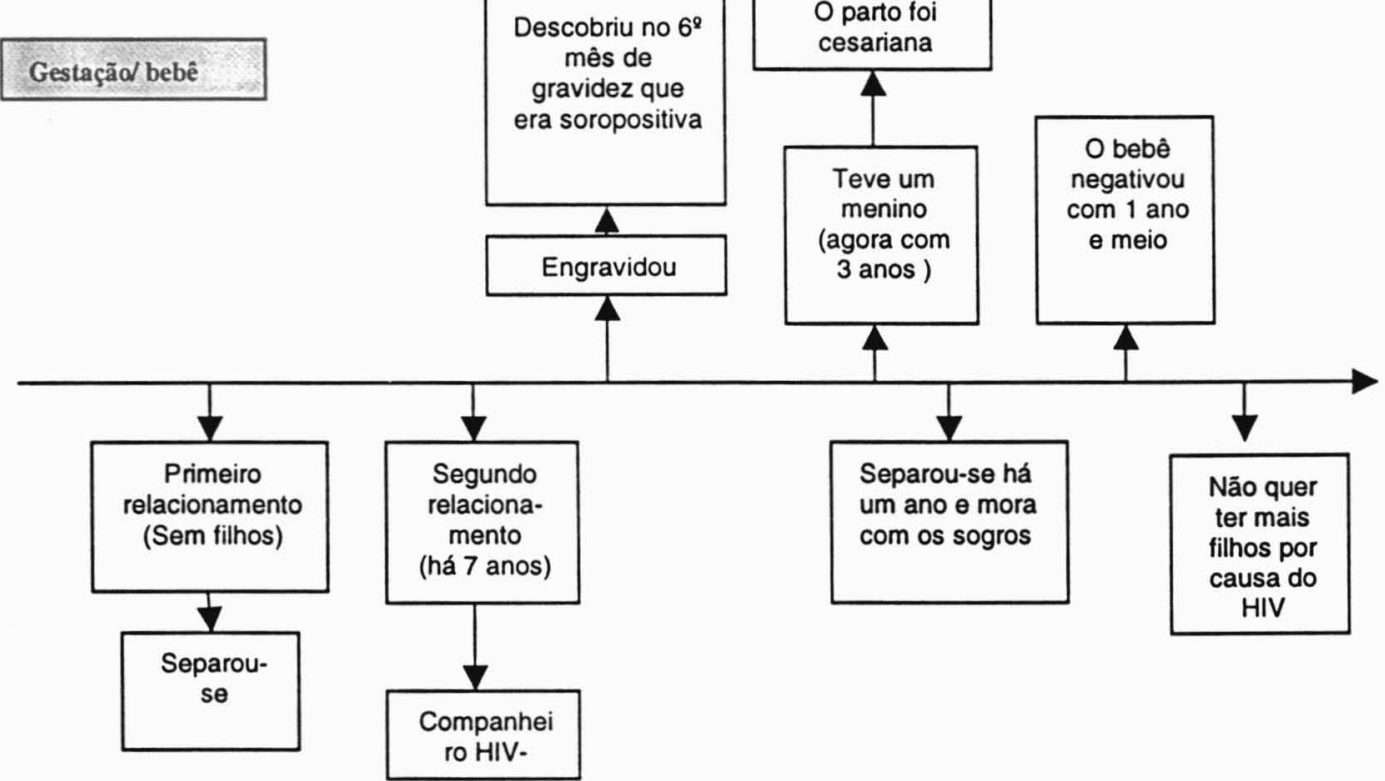

Situação

Ana Carolina tem 30 anos e mora na casa dos sogros. O diagnóstico de HIV ocorreu no sexto mês de gravidez e, embora a notícia tenha sido um choque, na época, hoje, passados três anos, ela construiu um outro sentido para essa descoberta.

"A: Foi um baque. Eu comecei a chorar na sala do médico. Aí ela me acalmou, falou reage! Eu falei, ah vou morrer? Aí ela falou não, você não vai morrer, não é assim não! Aí ela viu que eu tava sozinha, que eu estava uma pilha, só que eu não podia falar, é que até hoje ninguém sabe que eu tenho isso, tal. $A$ minha mãe não sabe, minhas irmãs não sabe. Só a família do... A minha sogra, que ela me ajuda muito. Só ela que sabe, né?

E: E como foi, Ana, quando te deram a notícia?

A: Eu fiquei...Me deu um choque. Eu comecei a chorar. Ai depois ela foi conversando comigo, me acalmou, né?" 


\section{(...)}

"E: $E$ quando você estava grávida, você falou que estava preocupada se iria ficar doente ou não, se o nenê tivesse algum problema. E se ele tivesse nascido com HIV? Como seria?(...)

A: Ah, se ele tivesse, tudo bem. Eu ia cuidar bem. Eu ia trazer na consulta todo més. la ser normal porque também, né? É, porque, ah... Ele também não pediu para nascer. Eu fiquei grávida e eu não sabia que eu tinha. Se eu nāo tivesse grávida eu não ia saber. Foi grávida que eu fiz exame e soube".

Seu companheiro não é soropositivo e Ana acredita que foi infectada pelo primeiro companheiro. Após a descoberta do HIV, Ana e seu atual marido foram se afastando, sexualmente, até que há um ano, deixaram de ter qualquer contato. A família dela desconhece a sua situação, e todo o suporte que recebe é proveniente da família dele.

"E: E como é que as pessoas acolheram a sua decisão de ter um filho. Seu companheiro, lá. Vocé estava grávida e tinha o HIV. Como é que foi? Como ele recebeu essa notícia?

A: Ele não falou nada. A minha sogra ficou assim,né? Ela ficou muito...porque foi um baque também para ela. Ela pensou um monte de coisa, queria me mandar embora, sabe? Aí depois ela conversou muito, eu trouxe ela aqui no hospital, ela conversou e aí foi que ela ficou do meu lado. Que ela não podia me jogar na rua com a barriga e tudo".

Sobre o fato de ter recebido a notícia da infecção, durante a gravidez, e precisar tomar remédios para a prevenção da TMI, Ana comentou que, embora o momento tenha sido difícil, ela pôde ver nos remédios um benefício para seu filho.

"E:Você disse que foi um baque receber essa notícia. Como é que é, além de receber a notícia de que está com o HIV, está com o HIV e esperando um bebê? Como é isso?

A: Então, eu fiquei com medo do meu filho nascer... Morrer. Assim, nascer com problema.

E: Com medo?

A: É assim, com problema, defeituoso. Assim, criança que nasce com problema.

E: Mas com problema físico?

A: Assim, problema físico, mas também ter a doença. Ai eu fiquei com medo disso e dele não sobreviver. Passou um monte de coisas pela minha cabeça.

E: E o que passou pela tua cabeça? Que teu filho ia ficar doente, que não ia sobreviver?

A: Medo que eu ia perder assim que eu tivesse ele, sabe aquela coisa?"

Ela foi encaminhada para receber suporte psicológico, individual e grupal, e considerou esse processo muito importante para a compreensão do que se passava com ela, graças ao contato com outras pessoas, em situações similares.

"E:E ai? Como é que você fez?

A: Eu tava no hospital, foi horrivel. Dal depois eu fui encaminhada lá pro... Cachoeirinha. Eu passei no... Psicólogo lá e ai o Psicólogo conversou, dá é que eu fui mais... que eu fui mais acostumando que tinha um monte de mulheres. 
E: Vocé estava passando em grupo?

A: $\dot{E}$, em grupo. Eu tava grávida e as mulheres, eu fui me acostumando, né? Orientando, né?

E: Então conversar com outras mulheres que estavam na mesma situação foi uma coisa que te ajudou?

A: Ajudou, né? Aí eu vi que meu filho, não é todos que nascem (com HIV) também."

O parto ocorreu sem problemas e a situação da alimentação do bebê, no pós-parto, gerou a invenção de uma desculpa: o fato de não amamentar era justificado por ter "hepatite".

"A: É também. Daí todo mundo estava comentando que eu não podia dar mamar, ai eu falava que eu tenho hepatite (risos). Porque foi uma coisa que me veio assim na cabeça, né? Eu tenho também, né?

E: E não amamentar o bebé, como foil?

A: Porque não podia amamentar... Ah, eu tinha vontade de amamentar, né? Quando vocé está grávida, porque dá essa vontade. Mas al eu falei, não né? Não posso, fazer o que?

E: Você tinha leite?

A: Tinha, mas ai eles colocam enfaixado...

E: Enfaixam.

A: Al depois secou.

E: Foi dificil pra você não amamentar?

A: Foi. No começo. Depois fui me acostumando, me adaptando, porque não posso e também porque a gente vê que se ele pegar vai ser pior, né? Então vou me conformar, né?

E: E essa idéia de que vocé tinha hepatite. Como fol as pessoas perguntando "por que?"

A: Aí eu não sou muito, não sou muito de detalhes. Eu falei da hepatite, pronto. Aí quando vinha médico e perguntava e falava e mandava olhar na ficha. Ai olhava e "ah, tá, tudo bem". E tinha aquilo, né?"

A experiência da maternidade foi bastante importante para Ana. No primeiro casamento, ela não conseguia engravidar e temia "ser diferente das outras mulheres", por não ter filhos. Ela afirmou que, apesar de ter desejado ter dois filhos, em função do HIV, mudou de idéia. Entretanto, em seu discurso, surgiu uma fala, que permite observar que esse assunto está em aberto, quando refere que gostaria de ter um "parto normal", caso "acontecesse" uma outra gravidez.

"A: Mas eu não pretendo ter outro filhol

E:Então, essa é a próxima pergunta!

A: Ah, tá. Porque eu tenho medo porque... Eu pretendo ter um filho só

porque eu tenho medo de acontecer um acidente.(..)

$E$ : Vocé falou que não pretende ter mais filhos...

$A: A h$, ou não sei assim. Eu tinha vontade de ter outro, mas, assim, quando eu vejo uma criancinha me dá uma vontade de ter outro. Mas aí depois eu volto atrás, eu penso em mim, no meu problema, se ele nascer com... Eu penso dele nascer igual a mim, né? HIV... Aíé...

E: Se ele nascer com HIV e ai?

A: É triste né? Ter esse problema. Eu não tenho nada, não sinto nada, mas tem que acompanhar...

E: Fazer os exames, né?

A: Os exames. Ficar tudo certinho, ai meu Deus!

$E$ : Você acha que se não tiver outro filho, vai estar poupando ele? 
A: É.

E: De passar por isso tudo?

$A: \dot{E}$, mas se acontecer, porque ninguém nunca sabe, né? Aí eu vou, tentar parto normal.

E: E quando é que você começou a pensar em ter um filho?

A: (...) Ah, porque eu via todo mundo, todo mundo quer ter um filho. Eu não queria ser diferente, eu também quero ser mãe. Eu falei dever ser bom, né?"

(...)

"E: E você acha que o fato de vocé ter o HIV é motivo para você pensar em não ter mais filhos?

A: É.

E: A sua sensação de que ele venha com HIV?

A: É por aí. No início eu pensava em ter outro, mas aí...Um só é ruim, vou ter dois. Aí...

E: Se você não tivesse o HIV, você teria o segundo?

A: É... (pausa)"

Sua visão de uma mulher vivendo com HIVIAids, que decide ter um filho, suscita uma questão importante: "ela tem direito, se quiser arriscar", embora ela reconheça que as pessoas consideram essa decisão, uma decisão de "mulher doida".

"E: Agora, e as pessoas em geral, porque existe preconceito em relação ao HIV e tem quem diga que se tem o HIV, não pode ter filho. O que você acha disso?

A: Quem tem HIV não pode ter filho?

E: O que vocé acha disso?

A: Ah, eu tive meu filho. Eu não sabia também. Mas se eu pudesse, eu acho que eu ia ter mesmo assim, sabe? Eu acho que não ia mudar nada. Mas agora eu não quero ter outro por causa disso, nê? Mas eu acho que não... Não é, acho que não.

E: A decisão de ter um filho não é um problema para as outras pessoas?

A: Eu acho que não.

E: É uma decisão sua.

A: Porque eu acho que eu conheci uma pessoa lá no grupo que tinha mais filhos. Tinha uma filha, estava grávida $\theta$ a primeira năo teve, ai ficou grávida de gêmeos. Foi depois de mim. Ela teve e eles não teve (HIV). Mas ela não tinha também doença. Foi normal e ela me fez pensar um monte de coisa dos outros. Poder entender, né?

E: E voce acha que essa mulher tem o direito de ter o filho dela?

A: E. A minha sogra falou "ah, que mulher dolda". Sabe? Ah, ela tinha direito, se quiser arriscar. Normal".

Outra questão importante pode ser destacada em seu discurso: o HIV, enquanto um segredo, acaba por isolar a pessoa, levando-a à solidão e medo do preconceito.

"E: Você se sente sozinha?

$A:$ Ah, às vezes. Eu me sinto solitária, não tenho com quem conversar, mas al eu vou trabalhar, eu converso um pouco porque eu trabalho na casa dela.

E: Mas você já contou pra ela?

A: Não.

E: Então também não pode conversar com ela?

A: Não. Não converso disso, converso de outras coisas né? Não posso contar porque se não eu vou ser mandada embora.

E: Vocé acha que vai ser mandada embora?

A: Claro, se ela souber. Ninguém... As pessoas têm muito preconceito. 
E: Vocé decidiu não contar.

A: É um segredo".

É interessante notar que Ana Carolina apontou que foi, justamente, por estar grávida, que foi diagnosticado o HIV. Nesse sentido, parece haver uma elaboração consciente para a questão. Mas, quando Ana falou de seu medo de que o filho viesse a "nascer... morrer", é possivel perceber um ponto em que os significantes vida e morte se conectam, numa relação que aponta para um Real, para além das palavras. Nesse entrelaçamento entre significantes, surge um hiato, que tem o efeito de engendrar, não só angústia, mas, também, uma questão para o sujeito.

A decisão de ter um filho parece ter origem nas relações de identificação imaginária com o Outro. "Ah, porque eu via todo mundo, todo mundo quer ter um filho. Eu não queria ser diferente, eu também quero ser mãe. Eu falei dever ser bom, né?". Esse tipo de identificação é o que observamos na relação do sujeito com o Outro, no primeiro patamar do Grafo do desejo [m-i(a)] (LACAN 1998).

Um outro ponto importante, em seu discurso, é seu medo de que o filho nascesse "defeituoso". O que podemos levantar, como questão, é que a função do filho (sua relação com o filho), também, processa-se no patamar, descrito acima, ou seja, a partir de uma identificação imaginária. Um filho "defeituoso" seria o "resultado" de uma "mãe defeituosa", o que coloca, em questão, o HIV. Um filho "saudável e perfeito" garantiria a "superação" do HIV, podendo apontar para um resgate narcísico da mãe. 


\subsection{4 - Flávia: que está grávida e ainda não caiu na real}

Síntese: Ela tem 24 anos e está grávida. É cabeleireira e estudou até o segundo grau completo. Seu companheiro, também, é soropositivo, e ambos sabem de sua situação sorológica, há quatro anos. A gravidez não foi planejada, e o casal faz uso esporádico de preservativo masculino. O casal teme que a situação da gravidez revele seu diagnóstico de HIV para suas famílias. Quando soube que estava grávida, pensou em abortar, pois acreditava que seu filho nasceria soropositivo. O médico informou que havia baixo risco de infecção para o bebê, caso ela fizesse tratamento adequado e, em função disso, o casal decidiu levar a gravidez adiante. Se o risco de TMI fosse alto, o casal teria optado pelo aborto.

Figura 11 - Diagrama da linha narrativa relativa à entrevistada Flávia

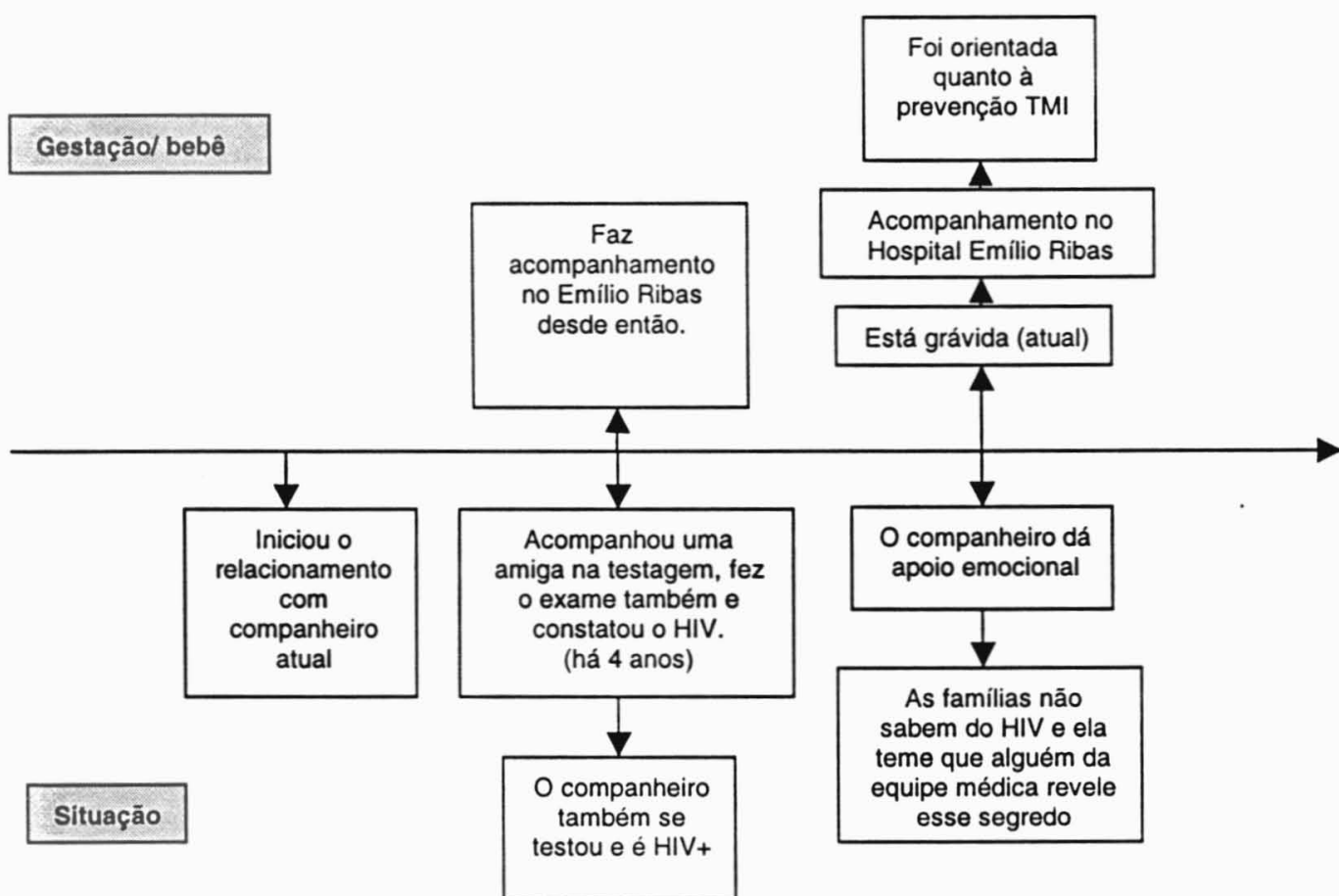

Flávia descobriu que era soropositiva, quando decidiu que também faria o exame, ao acompanhar uma amiga ao serviço, para fazer o teste. Ao constatar que tinha o vírus, seu namorado fez o teste, com resultado, também, positivo. Ela tinha, então, 17 anos, e decidiu que não contaria sobre o HIV para ninguém de sua família. O marido contou para um irmão, que começou a chantagear o casal, pedindo dinheiro, ameaçando contar sobre o HIV para a família dela. A manutenção desse "segredo" teve, como consequência, um 
sentimento de solidão. Sua preocupação, no momento, é que alguém revele, no hospital, esse segredo para sua família.

"descuido".

O casal não planejou essa gravidez, que, segundo ela, foi um

"E: (...)Como foi sua decisão de ter o bebê?

(...) F: Quando era antes do meu marido descobrir que era soropositivo a gente tenha relação sem. Agora estou tendo com preservativo, mas de vez em quando eu descuido. (risos). Foi que eu descuidei, que aconteceu!

E: O que vocé acha que acontece quando descuida? O que tem a ver?

F: Descuido é você não usar nada. Saber que você tem essa doença e decidir não usar. É que as vezes machuca e eu falei, deixa sem. Acho que foi nessa época de Fevereiro, carnaval, que foi sem. Aí... Mas pra mim nunca eu ia engravidar. A minha irmã fala "essa menina al é estéril". Por causa do problema, né? Todo mundo pensava que eu era estérill".

O casal havia decidido que, se o risco de transmissão fosse "alto", fariam um aborto. Mediante explicações do médico de que o risco de transmissão estaria em torno de $4 \%$, decidiram levar a gravidez adiante.

"(...) Se der da criança ter, porque quatro porcento tem esperança, muita esperança. Agora se for assim setenta porcento de... a gente não tinha. Al eu não sei se eu ia ter, nāo.

E: Você chegou a pensar em não ter o bebé?

F: É, se fosse nessa condição eu não ia ter o bebê. Em tirar, não ter. Eu pensel, eu já passo por isso e ainda ter e passar pro seu próprio filho. Eu falei ah nãol Aí eu pensei em tirar".

Foi orientada, pelo médico, quanto à impossibilidade de amamentar, o que fez com que ela procurasse justificativas para compensar tal fato.

"F: É, não vou poder amamentar.

E: E o que vocé acha disso?

F: Eu só espero que os peitos não caiam. (risos)

E: Vocé tem essa informação, de que se amamentar faz os peitos caírem?

F: Da minha irmã caiu muito. (risos). Eu sei que é uma dedicação de mãe e filha, né tudo? Mas eu acho até bom não amamentar.

E: Então você está pensando que é até bom.

F: É, simné?

E: E como você vai alimentar o bebê?

F: Ah, com aquele tipo de caixinha, de nome lá, como é que é? De leite... É aquele Nan, aquela coisa toda. Isso al eu já sei".

acolhimento, por parte da equipe, tem sido importante para Flávia, mas ela está, ainda, sob o impacto da notícia. Ela não observou nenhum tipo de julgamento, por parte da equipe (ou de quem quer que seja) quanto à sua decisão de ter um filho, sendo soropositiva.

"E: E aqui (no hospital), pelo fato de você ter o HIV e estar grávida?

F: Ah, não sei, porque agora é que eu estou ouvindo as coisas. Por enquanto ainda não tive nenhum olhar torto.

E: Mas você imagina que isso pode acontecer?

F: Não sei. Acho que tudo pode acontecer, né? A gente está aqui e tudo pode acontecer, então a gente tem que estar preparado pra tudo. Eu não ligo muito para essas coisas não. Preconceito eu sei que existo ainda, muito, muito, 
muito. Mas ah eu não me encano muito não. Às vezes eu tenho que vir, um mês, outro mês e tenho que lembrar. Eu tenho que vir aqui, al eu lembro. Eu falo, ah, eu tenho que ir lá. Só assim que eu lembro".

(...)

"E: Então assim, você vai ver como vai ser, pra onde vai ser encaminhada. Mas vocé está sentindo firmeza?

F: Tó. Mas eu ainda não cai na real que eu estou grávida! (risos)"

(...)

"E:O que é para você ter um filho?

F: É uma coisa estranha. (risos). Porque eu ainda não me adaptei nãol É uma coisa de intruso porque eu ainda não me adaptei não".

O relato de Flávia não deixa dúvidas de que o HIV teve grande influência na sua decisão de ter, ou não, um filho, o que não a impediu de correr o risco de engravidar. Entretanto, mediante a possibilidade de alto risco de infecção do filho, ela não relutaria em interromper a gravidez.

A questão do HIV permanece como um segredo importante para Flávia. A gravidez colocou em evidência essa questão, pois ela se pergunta como vai manter o segredo, caso algo fora de seu controle "a denuncie". Ela tem a fantasia de que alguém da equipe vai revelar o segredo, principalmente, no momento da internação, para a realização do parto.

Ainda sob o impacto da notícia da gravidez, o seu discurso mostrou grande pragmatismo: se 0 bebê fosse soropositivo, 0 casal decidiria pela interrupção da gravidez. Vemos, então, que Flávia só se permite "produzir algo perfeito e saudável", caso contrário, ela rejeita sua "produção". Essa perspectiva não os impediu de correrem o risco de gestar um bebê, que pode ser soropositivo. Tal postura nos faz refletir qual seria o papel de um filho para esse casal? De antemão, podemos levantar a hipótese de que o filho é um objeto, que pode ser "modelado, determinado, escolhido". Parece haver uma tentativa de controle da situação que, na verdade, denuncia o descontrole que o casal enfrenta, perante o fato inexorável de serem soropositivos. Parece que o filho só pode ser incluído nessa família, como uma expressão da superação do HIV, caso contrário, corre o risco de ser alvo da projeção familiar, e tornarse o "intruso, que denuncia a falta do casal". 


\subsection{5 - Mariana: que se sente culpada pela morte do filho}

Síntese: Tem 23 anos. Engravidou em 1998, e não houve testagem para HIV. Após o parto, seu filho adoeceu, e a familia foi testada, descobrindo que todos eram soropositivos. $O$ bebê faleceu aos quatro meses de vida. O companheiro (usuário de drogas injetáveis) faleceu seis meses após w nascimento do bebê. Mariana relata dificuldade de formar novos laços afetivos, por ter medo de perder novamente a pessoa querida e, além disso, fala de um sentimento de culpa, em relação ao filho, que faleceu.

Figura 12 - Diagrama da linha narrativa relativa à entrevistada Mariana

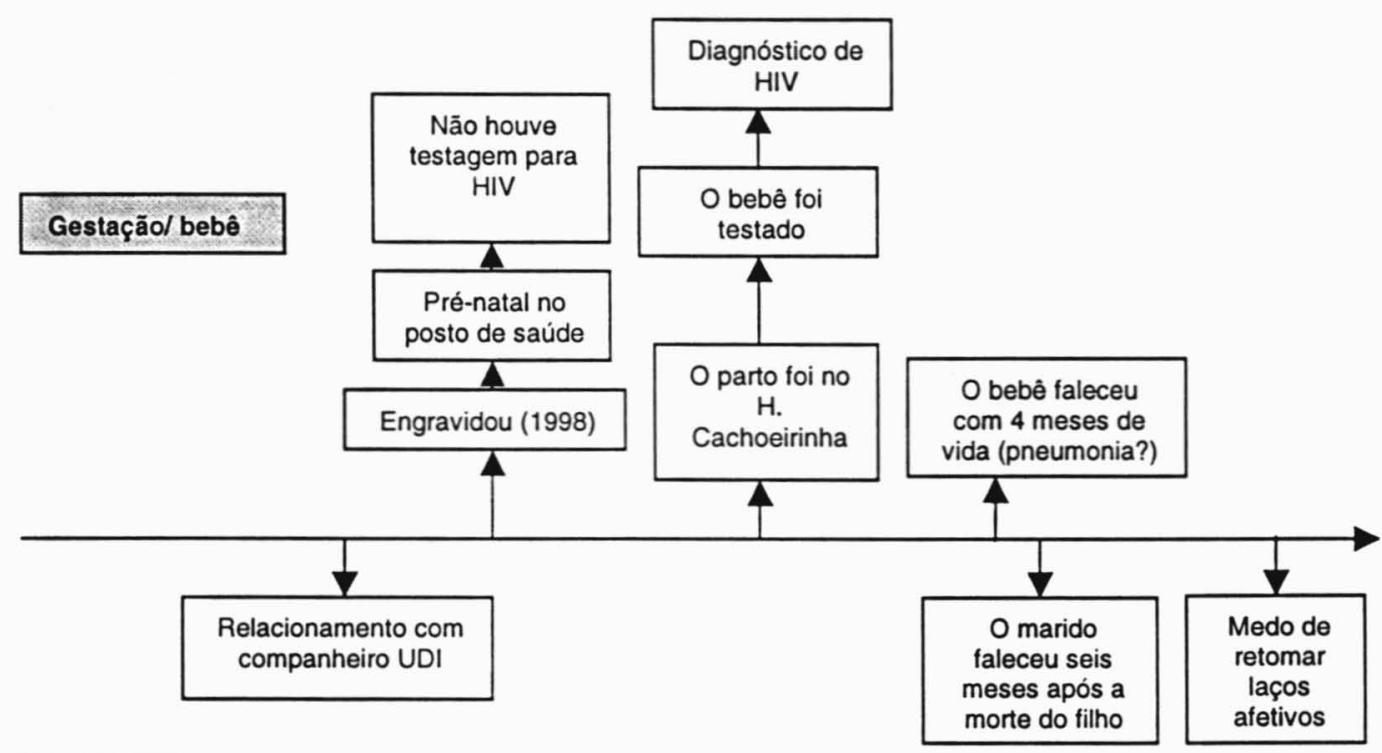

Situação

Quando olhamos os fatos da história de vida de Mariana, constatamos muitas perdas: de sua mãe, de seu filho e de seu companheiro. É interessante notar que, em seu discurso, houve muitos momentos em que ela produziu tiradas espirituosas, a respeito de si mesma, rindo de sua história.

Em 1998, descobriu que estava grávida e foi ao posto de saúde para realizar acompanhamento pré-natal. No pós-parto, recebeu uma "estranha orientação": não poderia amamentar seu filho, enquanto não chegassem os resultados de alguns exames. Foram horas de intensa angústia, até receber 0 diagnóstico de HIV.

"E: E como foi isso? Você recebe essa notícia lá no hospital, o que você sabia a respeito do HIV? Que informação você tinha antes? 
M: Ah, eu sabia que pegava pelas relações. Só que é assim, a gente acha que nunca vai acontecer com a gente. Esse é o grande problema. Você entendeu? A gente acha que não vai...

E: Você acha que aquilo nunca ia te acontecer...

$M$ : Clarol Eu sempre, nos outros relacionamentos, sempre usei camisinha.

Fol só desse. Eu pensava, eu me cuido. Sempre saí com quem eu amo. Hoje em dia tem também muito isso, muita gente ser perde bastante, nāo sabe com quem anda. Você não pode confiar".

Embora a notícia da sorologia positiva tenha causado grande impacto, Mariana contou que recebeu grande apoio da equipe médica no hospital.

\author{
"E: Mas você sentiu que as pessoas que estavam lá conversando com você, \\ como vocé disse, foram acolhedoras? \\ M: Foram. \\ E: Deram apoio? \\ M: Foi. A médica foi maravilhosa, eu esqueci o nome dela. No começo eu \\ nāo queria aceitar fazer tratamento. Ela falou que ia na minha casa, sair \\ do hospital e mandar alguém contar pra minha familia se eu não fosse. \\ Eles ainda não sabiam. Que ela queria que eu fizesse tratamento. Ela foi a \\ pessoa mais importante de eu fazer o tratamento".
}

Mariana relatou a situação de perda de seu filho e de seu marido, com grande objetividade, mas ficaram destacados, além do sentimento de culpa, em relação à morte do filho, uma certa resignação em relação à morte do companheiro.
"M: Era menino, W. E al iam fazer o exame nele pra saber se estava muito alto de virus porque tem como negativar. Mas ele pegou uma pneumonia, então quer dizer. Ele já nāo tinha aquele anticorpo forte e ele faleceu. Al eu já quis fazer o tratamento. Acho que eu já tinha conseguido. Porque eu também, eu fiquei assim... Olha, eu escondi um pouco da minha familia, eu fiquei sem cabelo, eu perdi consulta do meu filho. Porque eu não sabia. Eu me sinto um pouco culpada. Eu me sinto, porque ele morreu. (...) Eu devia ter sido mais ágil. Sei lá o eu acho. Mas não, falaram que não é assim, que talvez tinha que acontecer... ele faleceu com trés para quatro meses. Quando ele la fazer quatro meses, ele faleceu."
(...)
"E: E como ficou o teu relacionamento com aquele teu companheiro?
$M$ : Continuamos junto.
E: Vocês continuaram juntos. Ele fez o exame?
M: Fez o exame aqui. E também que ele tinha. Porque ai mandaram ele fazere al depois passaram e mandaram a gente pra cá. E sabe o que ele fez? Ele não se cuidou, se entregou e ele faleceu em setembro".

A experiência de maternidade ficou atrelada à questão do HIV, à perda do filho, e posteriormente, à perda do companheiro. Ela avaliou que sua decisão intempestiva de ter um filho constituiu uma irresponsabilidade, que teve conseqüências drásticas (a perda do filho). Sua opinião sobre as mulheres soropositivas e que decidem ter um filho é de que se trata de uma decisão irresponsável. Mariana observou que outras pessoas tomam essa decisão, da mesma forma que ela havia tomado, sem refletir sobre o assunto.

\footnotetext{
"E: O que é pra você ter um filho?
}

M: O que é pra mim, ter um filho? 


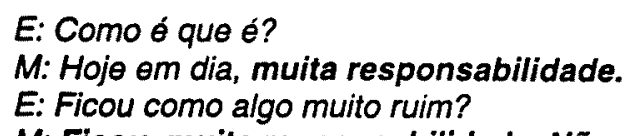

M: Ficou, muita responsabilidade. Não é brincadeira. Até no momento, uma pessoa que não tem HIV e fica pondo filho no mundo... já é... já é demaisl (risos). Quem tem HIV... demais. Tem gente que não vê isso. E: Tem gente que não pensa.

M: Não, não pensa, vai tendo filho, não cuida. Eu conheço. Eu não sei como consegue dormir. Como consegue viver? Eu fico me martirizando pelo problema dos outros.

E: E pra você não?

M: Não, tudo o que acontece comigo, eu já falei, eu procuro manter a cabeça muito alta. Eu agüento muita coisa, assim, pra não acontecer nada. Nem pra mim, nem pro bebê. Não quero ficar com peso de consciência de nada. E uma coisa muito séria. Eu acho assim, é uma coisa... uma responsabilidade.

E: Eser mãe?

M:Ai, é muito especial, muito importante. O pouco que eu vivi eu achei. Muito importante.

(...)

"E: Quando você ficou grávida, foi uma gravidez planejada?

M: Nãol Aconteceu! (risos) Aconteceu, virou Manchetel (risos)

E: Como acontece um negócio desses? (risos)

M: Não foi planejado, um dia a casa cai. Coloca as mãos o coração e recebe agora. (risos). É claro que não foi planejadol Mas tudo bem, a familia encarou normal, tudo bem.

E: Mas antes você tinha vontade de ter um filho?

M: Naquele momento não. Porque sabe com quantos anos eu engravidei? Com 19 anos! Não tinha terminado o magistério. Assim, não foi aquela coisa assim bonitinha, sabe?".

A decisāo de ter um filho tem que estar atrelada à possibilidade de ter um compromisso estável com alguém, mas ela teme, e chega mesmo a evitar conscientemente, qualquer envolvimento com um homem. Ao tomar a atitude de não se envolver com alguém, acaba por não ter que pensar na possibilidade de ter um filho. É possível observar que esse comportamento constitui um mecanismo de defesa, pois, agindo assim, ela não tem que lidar novamente com a perda, nem de um companheiro, nem de um filho.

"E: Vocé pensa em ter outro filho?

M: Ah, no momento não.

E: Uma das perguntas aqui é "você pretende ter outro bebê?" Como é isso para vocé? Você pensa na possibilidade de viver de novo a situação de ser mãe? M: Não, eu não quero passar de novo pela mesma situação e perder! (...)

"E: (...) Você estava falando da possibilidade de encontrar um parceiro e ter um filho. E você se preocupa se ele foi infectado.

M: Isso é o que me preocupa porque se eu chegar a ter esse objetivo, eu vou ter que ter o máximo de cuidado.

E: Mas e se você fizer todos os cuidados, a possibilidade é baixa de ele ser infectado. Mas e se ele for?

M: Ah, menina, ai eu vou morrer.

E: Por que?

M: Não, imagina.

E: Você se sentiria muito culpada?

M: Muito culpada. Eu posso morrer mas meu filho nãol Imagina.

E: Mas quem te garante que ele tendo HIV, vai morrer?

M: Não, mas fica muito doente. Eu conheço gente que tem filho com HIV e 
foi isso que passa. Que não negativou. É difícil.

E: Você não que passar....

M: Não quero. É muito dificil.

E: Mas você já passou por isso?

M: Já, eu falei gentel É muito ruim para uma criança sabe? Eles são tão bebês.

E: Sabe o que está acontecendo, acho que foi um impacto muito grande para vocé, não é?

M: Foi muito. Eu tive um filho, né? Acho que nāo seria tanto se ele não tivesse morrido. Acho que eu ia ficar mais sossegada. Se melhor se ele não tivesse morrido, se tivesse negativado, uma criança normal. Mas aconteceu porque fica ruim".

Mariana afirmou que retomou sua vida "normal". Tentando continuar a viver, ela parece ter estabelecido regras de convivência com o outro, e limites objetivos para seu envolvimento. Tudo o que ela vivenciou deixou marcas profundas, pois parece que o fato de ela estar viva, depois de tudo, é "fichinha". O preservativo é seu "melhor amigo", possibilitando que ela se relacione com alguém, sem, contudo, envolver-se emocionalmente.
"E: Então tá bom. Como você se vê hoje, sendo mulher, sendo portadora do HIV, tendo essa história que você passou? Como você se vê?
M: Eu fiquei mais madura, muito madura. Encarar a vida com qualquer problema. Agora pra mim, não tem problema nenhum. Tudo o que eu passei, pra mim, foi a escola da vida. Foi fichinha. Sou madura de tudo. Se tem alguma coisa que me incomoda, eu caio fora.
$E: E$ vocé acha que as pessoas te vêem assim também? Sua familia?
M: Acho que sim, acho que pensam a mesma coisa porque eu sou uma pessoa muito forte.
E: Eles sabem?
M: Sim, todos eles sabem.
E: E to apoiam?
M: Apoiam, pra mim continuar a mesma coisa, me tratando, me cuidando, me divertindo até a hora que dá.
E: Usa preservativo...
M: Uso, não vivo sem ele. Meu melhor amigol (risos)".

A história de Mariana permite-nos vislumbrar que ser soropositiva para o HIV e ter um filho podem trazer conseqüências. Mariana afirmou ter superado o "trauma" de suas perdas pessoais, mas vemos que isso não se dá, sem que ela adote um comportamento que, afinal de contas, constitui um sintoma: não se envolver afetivamente, para não correr o risco de perder.

O que parece estar em jogo é uma elaboração que aponta o seu desejo de ser mãe, como algo, possivelmente, deletério: ela já perdeu um bebê, por que iria se arriscar de novo? Ao dizer que não encontrou alguém que possa suportar, junto com ela, essa nova tentativa de ser mãe, na verdade, está apontando uma série de estratégias, para não se deparar com a questão. Temos a impressão de que a Aids devastou sua vida, não restando outra alternativa, a não ser, suportar a dor e, literalmente, ser sobrevivente. Foi a "escola da vida", ela mesma o disse. Então, ela aprendeu a viver com essa dor. 
6.1.6 - Miriam: que procurou ajuda e tratamento, não por si, mas pelo filho que esperava.

Síntese: Ela tem 33 anos, é separada, e mora em casa de apoio (Alivi). É exgarota de programa e trabalha atualmente na casa de apoio. Teve uma filha do primeiro casamento que mora com a irmã (ela tem 10 anos e é HIV-). Após a separação, voltou a trabalhar, como garota de programa, e engravidou de um cliente. Sabia-se portadora do HIV, havia cinco anos (descobriu após um aborto), mas não procurou nenhum tratamento, até a recente gravidez. Em função da gravidez, procurou tratamento e decidiu ficar com a criança (um menino de dois anos, HIV-). Ressaltou a importância do apoio institucional e afirmou que, não fosse pelo filho, estaria morta, pois não se cuidava e usava drogas.

Figura 13 - Diagrama da linha narrativa relativa à entrevistada Miriam

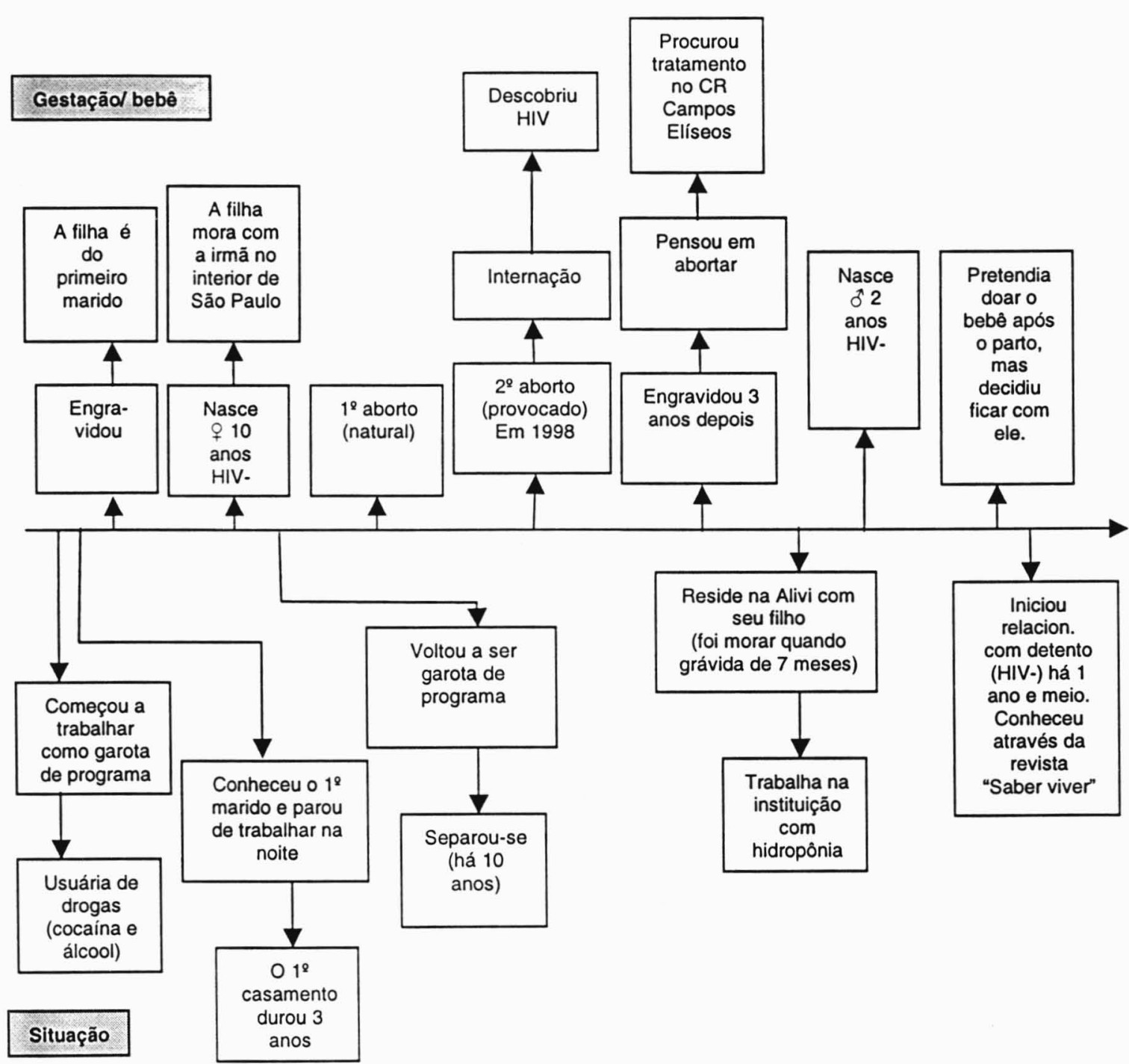


Miriam foi entrevistada, acompanhada de seu filho, R., de dois anos de idade. Esse filho é fruto de uma relação com um cliente. Miriam trabalhou, por mais de dez anos, como "garota de programa", antes mesmo do seu primeiro casamento. Quando se casou, pela primeira vez, abandonou seu trabalho como prostituta, engravidando de seu marido, logo em seguida. Assim que sua filha nasceu, (hoje a menina tem dez anos e mora com a irmã de Miriam no interior de São Paulo) separou-se, e ela voltou a trabalhar, como prostituta. Ela também contou que foi usuária de drogas (cocaína e álcool) e que deixou seu vício, somente quando engravidou de seu último filho.

Desde sua separação, ela teve dois abortos, sendo que, em função de complicações com o segundo deles, precisou ser internada, quando foi diagnosticada com HIV. Ela suspeitava que isso poderia acontecer e, por isso, a notícia sobre o HIV não causou surpresa, mas não procurou tratamento e continuou exercer a atividade, como garota de programa, e a consumir drogas.

Miriam só procurou tratamento para o HIV durante a gravidez de R. Sua maior preocupação era com a criança, pois ela continuava a usar drogas, que poderiam prejudicar a saúde do bebê. Ela pensou em fazer um outro aborto, mas estava com sete meses de gestação, decidindo, então, que teria o bebê e o daria para adoção.

"M: O fato de eu ser usaria (de drogas), bebia, muitas noites mal dormidas, 0 fato também poderia indicar uma criança com deficiência. Poderia trazer sérias conseqüências para ele. Então a minha preocupação era mais a criança" (p. 4).

Procurou tratamento no CR Campos Elíseos, de onde foi encaminhada para morar em uma casa de apoio (Alivi), especializada em atendimento a mulheres vivendo com HIV/Aids e que estejam grávidas. Nessa instituição, ela recebeu apoio, orientação, oportunidade de emprego e a possibilidade de optar por ficar, definitivamente, com seu filho.

"E: Como é essa instituição, a Alivi?

M: É uma instituição para moças portadoras e mães com filhos, na minha situação, porque eu era garota de programa e eu fiquel grávida $\theta$ eu tinha intenção de tirar o nenê, só que o tempo foi passando e eu não sabia de quantos meses eu tava, então, dal como eu já sabia que eu era HIV, eu procurei um centro de referência e comecei a fazer os exames pela criança porque eu também não tinha intenção de ficar com ela. Al me encaminharam para lá e eu estou lá até hoje. Vai fazer dois anos." (p. 1)

(...)

"E: $E$ vocé se sentiu bem, você se sentiu tranqüila? Porque vocé comentou que vocé achou que ele ia ter o HIV inevitavelmente. Se vocé tinha, ele ia ter. Mas $\theta$ al quando você soube que não é bem assim, como foi?

M: Não é bem assim. Mesmo assim eu não queria ficar com o menino, não tinha intenção de ficar com ele. Com o passar do tempo e todo o apoio que eu tive, do pessoal da administração, de colegas, eu acabei me 
apegando á criança e tô com ela até hoje. Ele tomou os remédios tudo direitinho, eu faço tratamento aqui, né?" (p.5).

(...)

"E: (...)Você está descobrindo uma outra profissão? E o que você acha disso?

$M:$ Ah, eu acho que eu nunca pensei em fazer isso. (trabalhar com hidroponia na instituição Alivi). Eu nunca imaginava $\theta$ até ultimamente hoje, eu mexo com esse tipo de coisa. Então hoje eu fico olhando pra mim e hoje eu vejo assim, que quando você está nessa vida, você nunca pára pra pensar porque vocé nunca tem tempo. Você nunca tem tempo. Mas hoje eu percebo que pelo fato de eu ser uma pessoa HIV, eu tenho meu filho para criar, eu tenho dois filhos, porque eu ajudo a minha irmã da maneira que posso. Eu... A vida não está destruída. Então hojo eu tenho outro pensamento. É lógico que eu quero sair do Alivi, arrumar um emprego, ter minha casinha, criar meus filhos $\theta$ quem sabe até poder ter um outro relacionamento, chegar a morar sozinha, esse tipo de coisa" (p. 7).

Miriam acreditava que, pelo fato de ser soropositiva e ter engravidado, seu filho iria nascer com o vírus, e iria viver pouco tempo. As orientaçōes da equipe de saúde, bem como conversas com colegas da instituição, onde mora, fizeram com que sua visão sobre a sobrevida de uma criança, que nasce com o HIV, fosse modificada. Entretanto, não foi a possibilidade de que seu filho pudesse nascer sem o vírus que a mobilizou para ficar com a criança, pois ela decidiu ficar com ele, antes, mesmo, de ter certeza de que ele não tinha o vírus.

O fato de não poder amamentar seu filho foi difícil, pois ela acreditava que o exercício da maternidade tinha relação com a amamentação: o "jeito de mãe" tem a ver com a possibilidade de amamentar. Uma mulher soropositiva teria "um leite ruim" e não poderia amamentar.

"E: (...) Como foi que você alimentou seu bebê quando ele nasceu?

M: Foi com o leite Nan. Porque não pode amamentar.

E: Vocé já estava sabendo... Como foi pra vocé não amamentar?

M: (...) Eu sei o que ele precisa ou não precisava e o fato de não poder amamentar tira um pouco, sabe? 0 seu jeito de mãe...

E: Você acha que não amamentar tira o jeito de mãe?

M: É, porque você nāo pode dar o peito porque o leite tá ruim.

E: E você tinha leite?

M: Nossa, muito, muito. Aquele monte de leite indo embora e vocé não poder dar pro seu filho porque o leite materno é uma coisa que...(ela se emocionou)" (p. 7-8).

O fato de ter um filho, sendo soropositiva, foi fundamental para Miriam e, graças a isso, ela se dispôs a mudar de vida e, assim, recebeu todo apoio necessário. Em função da gravidez, Miriam pôde realizar várias mudanças pessoais, inclusive, a possibilidade de receber tratamento específico, pois, segundo ela, a busca pelo tratamento se deu para preservar seu filho, não a ela mesma.

"E: Tá. E como é pra você ter um filho? O que é para você ter um filho? M: Hoje olhando meu filho, eu não criei a minha, mas nem por isso eu deixo de ter amor por ela. Mas hoje criando para o meu filho, é a coisa mais maravilhosa porque foi através dele que eu estou aqui. Se não fosse o meu filho eu poderia estar morta ou presa. Ou eu não sei o que poderia, 
ou poderia estar por ai como uma indigente pelas ruas, pelo fato das drogas. Então foi através dele que eu estou aqui. Eu me cuido e perdi muitas coisas. E hoje eu tenho um relacionamento também.

E: Você acha que o teu filho foi um estímulo pra viver? Pra enfrentar o HIV e se cuidar? $O$ fato de você ter ficado grávida foi um impulso que te mobilizou para a vida, para mudar a tua vida? Você acha?

M: Eu acredito que sim. Nāo foi uma coisa planejada e eu cheguei a ter o dinheiro pra mim poder fazer o aborto mas não fiz e na hora certa eu procurei ajuda e tive todo apoio. Não só eu como ele.

E: Esse apoio também foi fundamental, né?

M: Foi.

E: Você falou que sem isso talvez não pudesse...

M: Talvez não pudesse mesmol

E: E ser mãe, o que é ser mãe?

M: Ser mãe é estar de cabeça erguida pra criar seu filho, buscando novos horizontes. Eu acho que é a coisa mais maravilhosa do mundo.

E: Pra você ser mãe é enfrentar esses obstáculos, é algo maravilhoso?

M: É.

E: E ser mãe e ser portadora do HIV? Como é?

M: (pausa) Olha pra mim não está sendo difícil não porque eu sou uma pessoa que eu não tenho onde cair. Eu não tenho problemas nenhum de saúde.

E: Mas você acha que é diferente a gravidez de uma mulher que não tem o HIV de uma mulher que tem o HIV?

M: Ah, a única coisa é por causa do remédio, mas de resto não.

E: Mas tem uma coisa que é curiosa no seu caso. Vocé já tem uma filha e quando vocé a teve, vocé não teve todo esse apoio. Você não tinha HIV e agora que você tem, você esta tendo todo esse apoio. Não é interessante?

$M: E$, eu estou tendo todo apoio por causa do HIV.

E: Mas por causa do HIV. Interessante, nesse caso. Parece que ter o HIV, nesse caso, te ajudou?

M: Me ajudou'(p. 8-9).

(...)

E: Para o R., vocé acha que algum dia vai ter conseqüências para ele o fato de vocé ser portadora do HIV e decido ter um filho? A minha mãe é portador do HIV. Vocé acha que ele vai se perguntar isso?

M: Olha, eu acho que não, porque as coisas estão tão bem esclarecidas. Ele pode até pensar "A minha mãe é HIV, mas ela se cuidou e hoje eu sou filho de uma mulher portadora, mas eu não sou portador"

E: Entäo é uma coisa que vai admirar vocẻ?

M: Eu acredito que sim, eu acredito que sim. Porque eu não procurei me cuidar por mim, mas eu procurei fazer por ele. Fazer por ele" (p. 10).

O que chamou nossa atenção, na entrevista com Miriam, foi o fato de que ela atribuiu que as mudanças fundamentais, em sua vida pessoal, ocorreram, em função de sua última gravidez. Ela deixou de usar drogas, parou de trabalhar como garota de programa e procurou tratamento. Ela encontrou, por ser soropositiva e estar grávida, uma série de suportes institucionais, que The permitiram, além da mudança de profissão, uma retomada de cuidados com sua própria saúde.

Miriam deixa claro que não pretendia ficar com seu filho, mas quando ele nasceu, "apegou-se a ele". Podemos pensar que, naquele momento, naquela situação especifica, e, em virtude dos suportes institucionais a que tinha acesso, ela podia se apegar ao filho. Ela já tinha deixado sua primeira filha aos 
cuidados de uma irmã e, agora, a decisão de ficar com esse filho era algo, que dependia da possibilidade de cuidar do mesmo.

Quando perguntamos qual a função da gravidez e da maternidade em mulheres vivendo com HIV/Aids, ao analisar o sentido de uma entrevista, como essa, não podemos deixar de pensar que, para Miriam, a gravidez constituiu uma oportunidade ímpar de superar a marginalidade e retomar uma vida produtiva. O fato de ter HIV, configura-se como um problema que, paradoxalmente, permitiu acesso a uma vida mais saudável. 
6.1.7 - Bianca: que não quer se apegar à filha, porque acredita que vai morrer logo

Síntese: Aos 33 anos, mora em casa de apoio e deixou de se prostituir. Ela tem dois filhos, frutos de um relacionamento anterior, e que moram com sua mãe (um rapaz de 18 anos e uma menina de 13 anos, ambos HIV-). Engravidou de um cliente e pretendia dar o bebê para adoção. Dois anos após o nascimento da filha, Bianca adoeceu e já suspeitava do HIV. Descobriu que era soropositiva e o teste de sua filha foi negativo. Bianca afirma procurar "não se apegar à filha, pois está esperando a morte".

Figura 14 - Diagrama da linha narrativa relativa à entrevistada Bianca

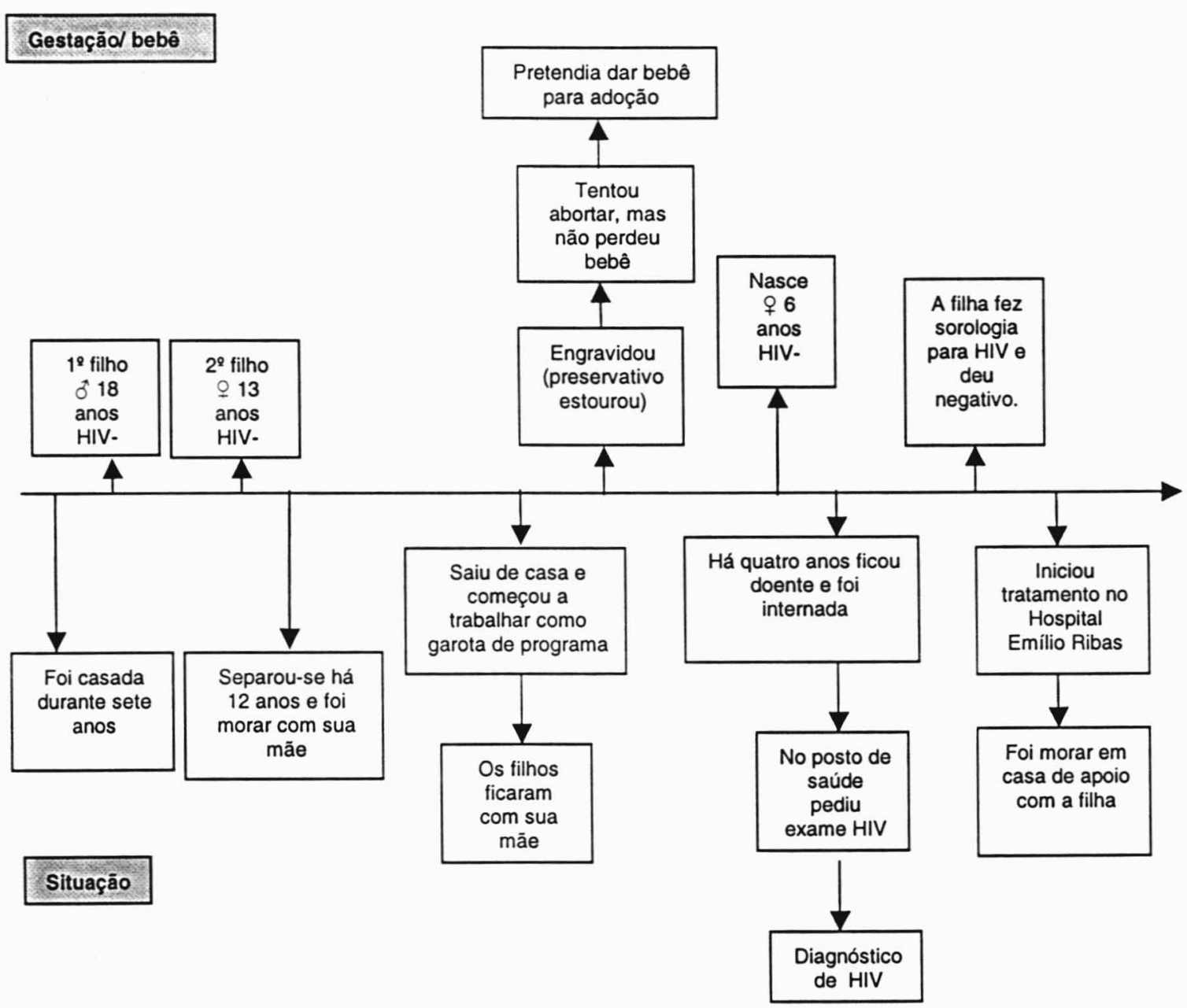

Bianca teve dois filhos do primeiro relacionamento. Quando o casamento acabou, ela foi morar com sua mãe e, após muitos desentendimentos, ela saiu de casa, deixando seus dois filhos aos cuidados da mãe. $O$ emprego, que 
havia conseguido, foi abandonado, durante as noitadas de carnaval. Ela decidiu, então, seguir uma amiga e passou a trabalhar, como garota de programa, até certo dia em que "o preservativo estourou com um cliente".

\footnotetext{
"B: Al, quando eu estava com dois meses que eu estava lá, já tinha juntado um dinheirinho, eu ia alugar a casa com mais duas outras meninas, né? A gente estava procurando casa direitinho... Por pura sorte minha, eu fui fazer um programa, a camisinha estourou e eu engravidei fazendo programa. Pura sorte né? Pura sortel

E: Foi sorte?

B: Foi sorte porque, como é que você, no dia... No dia errado, no momento errado, só que a criança deu certo" (p. 2-3).
}

Ela pretendia dar a criança para um casal adotar, mas, quando o bebê nasceu, ao vê-lo, resolveu ficar com ele. Bianca se emocionou, ao relatar essa decisão, pois, para ela, foi um momento muito difícil. Há, aproximadamente, quatro anos, Bianca adoeceu. Procurou um hospital e teve o diagnóstico de anemia, sendo medicada com vitaminas. Mas, ela desconfiou que talvez pudesse ter HIV e, então, procurou um posto de saúde e solicitou que o médico fizesse o pedido de sorologia para HIV. Quando soube que era soropositiva, ficou muito deprimida. Embora estivesse muito abatida, um dia foi a uma igreja e decidiu procurar tratamento. Conversou com outros pacientes e soube que poderia ter melhor sobrevida. Bianca foi encaminhada para morar em uma casa de apoio, junto com sua filha.

O HIV é um segredo, pois ela tem medo de ser vítima de preconceito. Ela iniciou um novo relacionamento e não contou sobre seu estado sorológico.

"Eu leio muito aquela revista Saber Viver. Na casa onde eu vivo ninguém sabe. Só eu $\theta$ Deus sabemos que eu tenho o vírus. Minha familia, meus filhos... só eu e Deus. Sempre venho aqui eu falo com o pessoal que eu tenho o colesterol muito alto, porque eu tenho mesmo." (...) "Eu falo que eu estou cuidando do meu colesterol. Eles não sabem que eu venho no Emílio Ribas. Eles sabem que eu venho nas clínicas" (p. 9).

(...)

"B: É lógico. Tenho um namoradinho. Ele não sabe que eu tenho. Eu uso camisinha. Eu não posso tomar anticoncepcional por causa do meu colesterol. Af tem que encapar o bichinho. Eu falo tem que ser bem encapadinho. Eu falo pra ele, não eu tenho problema de colesterol e todos os meus remédios estão sem etiqueta, eu tiro a etiqueta. Então eu falo todos esses remédios são para o meu colesterol, se eu tomar anticoncepcional junto, aquilo vai agravar a minha situação, então vou ter um infarto e vou morrer. (risos). Ele gosta muito de mim, coitado, ele usa preservativo.

E: Por que coitadol?

B: Não, (risos), eu fico pensando e se estourar preservativo com ele? Mas não...

E: Mas estoura muito preservativo?

B: Não, com ele não. Mas já aconteceu" (p. 10).

Bianca tem conhecimento de diversas situações de mulheres soropositivas e que tiveram filhos, e sua opinião sobre o assunto é que, se uma mulher tivesse certeza de que seu filho nasceria com o vírus, não deveria engravidar, ou levar a gravidez adiante, com o intuito de poupar a criança de um sofrimento maior. 
"E: E o que vocè acha de uma mulher que é portadora do HIV e resolve ter um filho?

B: Eu tive uma amiga na casa de apoio. Ela teve porque ela quis. E o menino não nasceu como vírus. E ela ficou internada aqui no Emílio Ribas, mais morta do que viva. (...) Quando ela saiu daqui ela foi para uma casa de apoio junto com o N., ela conheceu um rapaz aqui que também tinha. Ela falava pra mim, eu quero ter um outro filho. Eu falava, você é loucal Eu quero, eu quero, eu quero. E ela teve um menino. O pai é HIV e ela e o menino não tem. (...) Mas nunca se sabe se você vai por um bichinho no mundo para sofrer. $E$ se nasce um aidético, ai? Na minha época abortavam as criancas aidéticas, dá dó dessas crianças" (p. 11-12).

Bianca afirmou que procura não se apegar à sua filha, pois acredita que pode vir a morrer logo.

“ $B$ : $E$, de repente, a gente não sabe quanto tempo a gente vai ficar viva. Tudo bem, morrer a gente não vai morrer assim. Mas a gente que é portadora, a gente pensa nisso.

E: Ou será que vocé perdeu aquela certeza que todo mundo acha que tem, de que vai viver para sempre?

B: E. Aliás, a certeza é de que não vai viver para sempre. Até o pessoal lá de onde eu moro, acha estranho o meu jeito de falar, porque ninguém sabe, aí eu falo assim, porque tem velha lá e eu falo "eu não vou ficar velha". Como é que vocé sabe, se você não vai ficar velha? (...) A minha menina mesmo, eu fico pensando, ah, eu não posso me apegar a ela. Ou ela se apegar a mim. E se eu morro? Ela vai sofrer.

E: E você também. Você não sofre quando pensa assim?

B: (pausa). Viche! (se emocionou)" (p. 13-14).

Embora Bianca se esforce em deixar claro para o outro que está viva e procura viver com sua filha, da melhor forma possível, o fato de ser soropositiva parece interferir em seu relacionamento com outras pessoas, além da filha, à medida que ela passou a ser "fria" e encarar a morte de forma diferente de outras pessoas.

A história de Bianca ilustra a situação de uma mulher, que procura criar uma forma de "viver com HIV". Embora ela diga que ainda não morreu, sua atitude de "desapego" para com a filha é um mecanismo de defesa, que aponta para uma tentativa de preservar-se perante o inexorável, que é a morte. Em seu relato, temos a evidência de que, após o diagnóstico da infecção pelo HIV, a perspectiva da pessoa, perante a questão da vida e da morte, assume um viés específico, ocorrendo uma perda de "pseudocertezas", que o neurótico assume, para continuar vivendo, sem ter que se deparar com sua falta intrínseca. Ela mesma o diz: "Depois de passar tudo que eu passei, eu fiquei o que eu me tomein.

A descoberta do HIV re-edita a questão da castração, e, no caso de Bianca, o sintoma que ela nomeou como "depressão" mostra o sofrimento da perda do "corpo saudável imaginário". 
6.1.8 - Dia: que sentia prazer em estar grávida e que, depois do diagnóstico de HIV e da morte do marido, abriu mão desse prazer.

Síntese: Ela tem 29 anos e é artesã. Teve uma menina (agora com 5 anos, HIV-). Durante a segunda gravidez, seu marido adoeceu e foi internado, descobrindo-se o HIV. Ele faleceu, ainda quando ela se encontrava grávida. O segundo filho, hoje, tem 3 anos e é soronegativo. Dia mudou-se para São Paulo e mora na casa de seus avós. Foi atendida, em grupo de gestantes, e reconhece a importância do trabalho psicológico, grupal e individual. Após a segunda gravidez, fez laqueadura. Ela havia planejado ter quatro filhos, mas, em função do HIV, decidiu optar pela laqueadura.

Figura 15 - Diagrama da linha narrativa relativa à entrevistada Dia

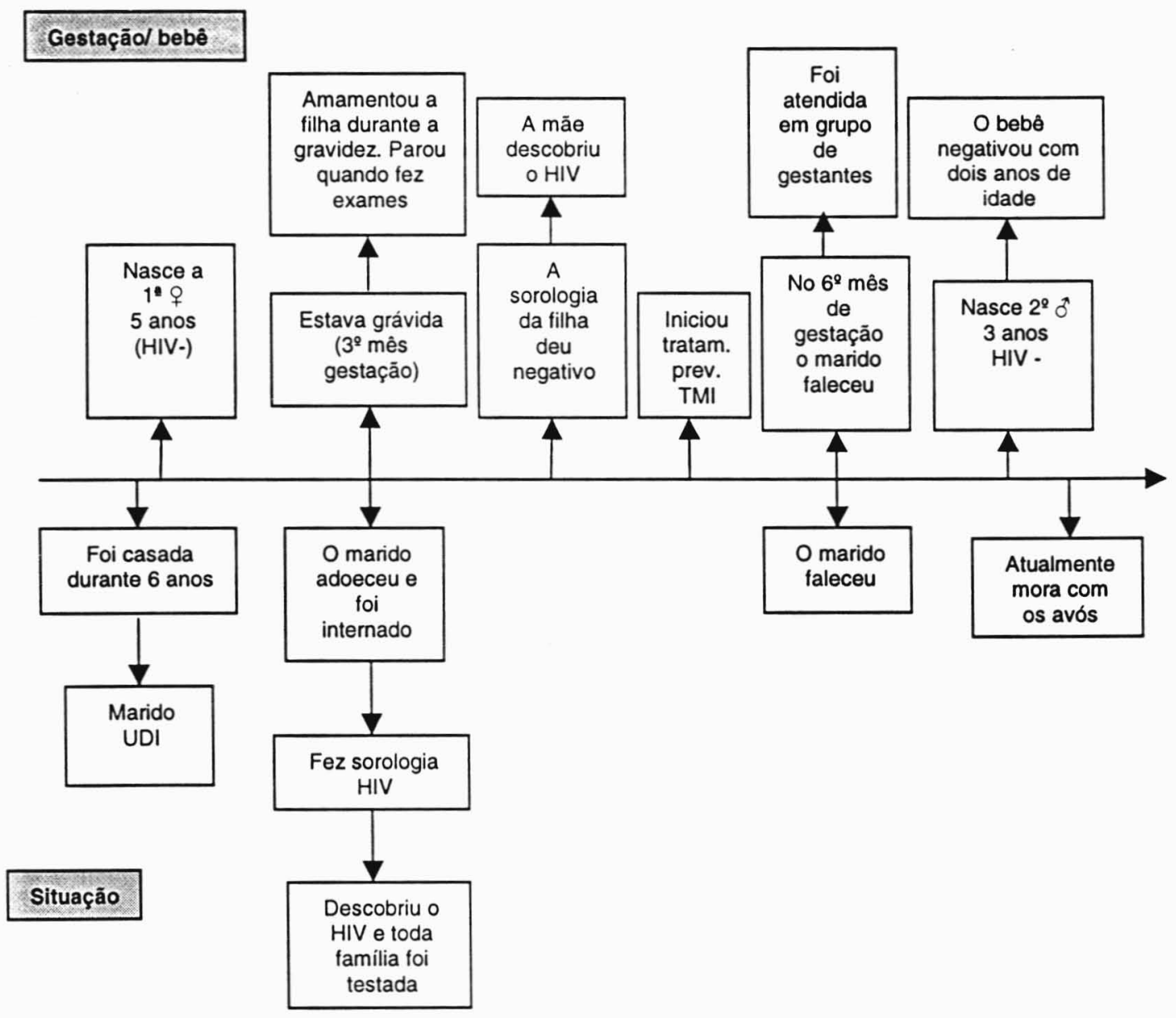

Dia tinha adotado um estilo de vida da contracultura hippie e, como tal, seu comportamento, embora considerado incomum pela sociedade, era "natural" entre seus pares. Dia consumia drogas (maconha e cocaína) e se relacionava com um homem, que usava drogas injetáveis. Para ela, a gravidez 
é um estado de plenitude e beleza, e a amamentação, a essência da relação natural da mulher com seu filho. Quando Dia engravidou, sentiu-se muito feliz e pretendia amamentar sua filha, o máximo de tempo possível. Sua filha estava com dois anos e continuava a ser amamentada, quando Dia engravidou, novamente.

Seu marido não estava bem de saúde e precisou ser internado. Nessa época, ela estava grávida de três meses. Ela começou a desconfiar que seu marido poderia ter Aids, pois ele era usuário de drogas injetáveis e, por isso, Dia decidiu parar de amamentar.

" $D$ : A parte mais dificil para mim foi a menina. Nem tanto pra mim. Eu nem ligava. Era mais assim, ai, a minha filhal Porque ela mamou no peito até dois anos e ai quando ele começou a ficar doente, que eu comecei a suspeitar, eu cortei o peito dela.

E: Bruscamente? Por causa do medo de...

D: De dar positivo... O exame. Eu falei, vou ter que cortar. E depois eu estava grávida e eu ia ter que cortar o peito mesmo pra não dar anemia no nené. Al foi aquela coisa né? Al a médica, não, vamos fazer os exames. Antes de ele ser intemado. Vamos fazer os exames nele e daqui um més vocé pega. Eu falei, nāo, vamos fazer tudo, eu, na menina, ele $\theta$ já... Ela falou, entāo vamos fazer assim, vocé está de quatro meses, vocé já começa a tomar a medicação antes mesmo de sair o resultado. Se sair o resultado e não der nada, a gente suspende. Se não a gente continua, porque já era para vocé ter tomado desde o comecinho da gravidez, né?" (p. 3).

$O$ resultado do exame do marido veio positivo para HIV, com um quadro grave de Aids, mas Dia se preocupou com sua primeira filha. O resultado do exame de Dia foi positivo para o HIV, mas sua filha não tinha o vírus. Quanto ao fato de estar grávida, não houve tanta preocupação, pois Dia tinha informações de que, se fizesse o tratamento durante a gravidez, seu filho poderia nascer sem o vírus.

O marido chegou a ter alta do hospital e voltou para casa, mas foi ficando deprimido e prostrado, afastando-se de todos, quando, finalmente, veio a falecer. Ela estava no sexto mês de gravidez.

"E:Como é que foi pra você, estar num momento onde gerava vida, estava grávida, né? E enfrentando toda essa barra e quando teu marido faleceu vocé estava enfrentando a morte. Como é que foi essa coisa, vida-morte, mortevida?

D: Não curtia minha gravidez. (foi ficando emocionada)

E: Não deu pra curtir?

D: Imagina. (chorando). Eu so chorava. Eu falava, ai tadinho do meu filho. Eu estava mal. Até o hoje eu estou assim bem mal.

E: Te emociona muito.

D: Tem época que eu não lembro, mas tem épocas que eu fico assim, sabe?

E: Vocé sente falta do teu companheiro? (ela concordou com a cabeça). $O$ que ele era pra você?

D: Ele era toda a força. Trabalhava junto. Tudo era junto sabe?

E: Vocé era muito apaixonada por ele?

D: Era muito apaixonada, muito amigo. A gente era muito unido, sabe?

E: Vocé se sente magoada por ele ter se entregado, não ter lutado?

$D: E$, às vezes eu fico brava. 


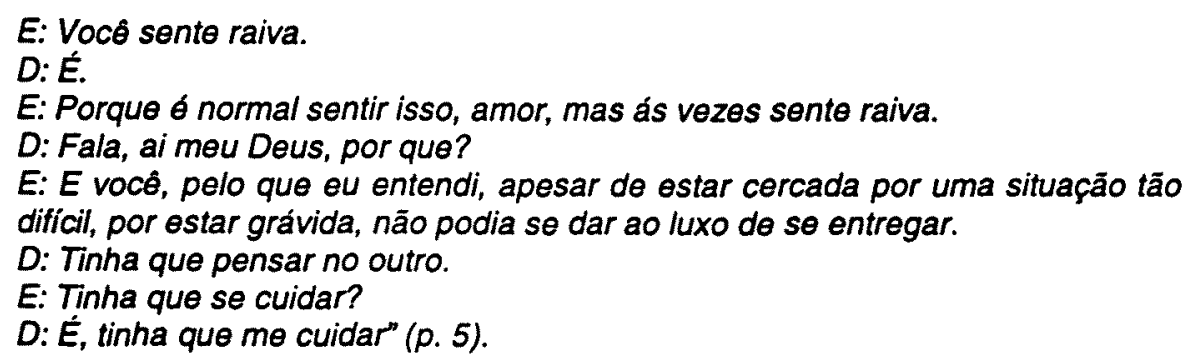

Inicialmente, foram atendidos por uma equipe de um hospital público de Florianópolis e, após o falecimento de seu marido, Dia e seus filhos se mudaram para São Paulo. Dia contou que a equipe, que informou sobre a situação do HIV, no hospital, foi displicente, deixando, tanto ela, quanto seu marido, sem nenhum suporte emocional. Quando seu marido faleceu, Dia pediu ajuda para seus avós, que foram buscá-la e a trouxeram para morar em São Paulo. Ela contou que, em São Paulo, foi bem acolhida pela equipe que a acompanhou na gravidez e parto.

"E: E como foi a reação das pessoas? Pelo que eu entendi, a equipe (do sul) que tratou vocé te orientou, mas você sentiu que vocé foi acolhida?

D: Não.

E: Vocé sentiu que eles estavam te informando?

D: Tanto é que no dia que eu fui fazer visita no hospital, saiu os exames, o resultado deles. Eu estava grávida. Não veio ninguém me falar. Ele que me deu a notícia, eu passei mal. Não veio ninguém perguntar, ah você está aqui, precisa de alguma coisa. Não. De falar, ah, não é assim. Não teve ninguém. Não falei com Psicóloga, ninguém. Foi uma coisa bem fria.

E: Só passaram a informação?

D: É. Eu estava dentro do hospital, perturbada e... eu via que ninguém parava pra conversar com ele, entendeu? Os médicos eram tipo assim, estavam vendo que isso não tá legal, estavam vendo que o paciente se abalou. Vamos passar ele num Psicólogo, conversar, né? Ninguém fez isso.

E: Você achou que isso teria feito uma diferença?

$D:$ Ah, sim.

E: Se ele tivesse conversado com alguém e se vocé também pudesse conversar, né? Porque vocé também estava vivendo aquela situação, né?

D: Não tinha ninguém.

E: Só podia conversar mesmo com ele.

D: Só mesmo com ele, mas eu não sabia o que falar.

E: E como vocé poderia falar com ele sabendo que ele estava depressivo tamberm?

D: Eu não sabia o que falar.

E: E você grávida. Você sabe que grávida já fica sensível?

D: Eu só sabia chorar...(...) Eu ia, eu ia no hospital, levava comida pra ele.

E: Vocé fez aquilo que era tua parte, o que era possivel?

$D: E$. Eu conversava com ele, falava para ele não ficar mal, que ninguém era culpado daquilo e que eu gostava dele e não estava com raiva. Que não estava perdido, né?"(p. 6-7)

(...)

"D: Tanto é que, antes de sair o resultado da minha nené, eu fui no hospital visitar ele $\theta$ acho que a enfermeira estava trocando a cama, arrumando os lençois e ela veio perguntar pra mim se de quantos meses ou tava. Ai eu falei tudo, né? Vocé tem outro? Eu falei, tenho, eu tenho uma menina, né? Al ela falou, mas ela é HIV positivo? Eu falei não, é negativa... não sei, eu falei. Espero que esteja negativa, eu estou pra receber o exame, né? Aí ela virou pra mim e falou assim, "ah, você tenha certeza de que vai dar positivo". 
Eu falei, por que certeza? "porque todos dão, impossivel". Aí eu já fiquei mal. Fiquei arrasada" (p. 6-7).

Dia realizou todo o procedimento de prevenção da TMl, e o parto de seu filho foi programado, mas, a espera pelo resultado do exame do filho gerou grande ansiedade. Dia acredita que, se uma pessoa tem o virus, ela terá dificuldades para ter filhos. Sua percepção de um casal sorodiscordante, sobre a decisão de ter filhos, é que o risco envolvido não compensa a possibilidade de ter um filho, que pode nascer sem o vírus.

"E: Como é que você via a possibilidade dele ter o víns?

$D:$ A possibilidade de ele ter? Eu não queria.

E: Mas a se ele tivesse?

$D$ : Se ele tivesse, eu ia fazer o que? Eu ia cuidar dele, tranqüilo, a mesma coisa. Mas eu acho que ia ser mais dele. la ser neurótica.

E: la ter mais preocupação?

D: la ser neurótica.

E: Não é questão de neurose. É preocupacão mesmo com a saúde. Mãe quase não tem preocupação com a saúde, não é mesmo? (risos)

$D:$ Imagina. Eu quero que ele cresça, que tenha filhos.

E: $E$ ter HIV impede de ter filhos?

D: Agora nāo, né? Porque agora eles fazem uma...Eles limpam o esperma do homem. Tem tratamento agora. Eu não sabia, mas eu imaginava. E se ele casar com uma moça que não é soropositiva? Como é que ele vai ter filhos, ele sendo soropositivo?

E: E se ele tiver o HIV e casar com uma moça que tem HIV e quiser ter filhos?

D: Não tem problema. Tranqüilo.

E: Ai tudo bem?

D: Não, mas eu imaginava. Como é que ele vai ter filhos se a moça não é soropositiva? Uma moça saudável? Não é soropositiva, como ele poderia ter filho?

E: Tendo um filho soropositivo.

D: Mas ela não iria se contaminar?

E: Então isso que eu estou perguntando para vocé. Como é que vocé imagina que uma pessoa vai poder ter...

D: Eu não queria isso para ela, como eu não iria querer isso para a minha filha, entendeu?

E: Porque tem assim, uma questão. As pessoas podem querer bancar mesmo.

D: Eu nāo acho isso certo.

E: Vocé acha que o ideal é a gente tentar evitar a infecção e evitar um filho que tenha a infecção?

D: Isso.

E: Mas tem casais que bancam.

D: Uma loucura.

E: Vocé acha isso uma loucura?

D: Vocé está jogando a sua vida e de um ser humano que... Puxa, não pode ser assim.

E: $E$ se hoje em dia existem métodos que podem evitar a infeccaão do companheiro, seja homem ou mulher, pode ser utilizado esse método?

$D:$ Al, sim. Ai, tudo bem, pode ser utilizado esse método desde que eles convivam com seus fantasmas tranqüilamente, né?

E: E dá para conviver tranqüilamente com seus fantasmas?

D: Não sei. (risos). Não sei se a gente pode conviver.

E: Porque fantasma é fantasma.

D: Sim, se é uma moça que não tem nenhum problema de conviver com um rapaz que é soropositivo ou vice-versa. Tudo bem, desde que tenha cuidado para um não contaminar o outro, porque não é justo né? 
E: Mas é uma questão difícil.

D: Não é justo isso. Você vai mudar a vida de uma outra pessoa, tomando remédio.

E: E se a outra pessoa não vê isso como um problema? Estou perguntando isso pra você porque...

$D:$ Se ele não vê isso como um problema para ela..

E: Mas é uma escolha difícil. Para o teu modo de ver, não é por aí.

D: Não é por aí.

E: Deveria se mais... Mais cuidadoso.

D: Se a minha filha, ela é negativa. Se por acaso ela namora um rapaz que é soropositivo, eu não vou querer que ela tenha um filho. Pra que? Para passar a vida inteira tomando remédio?

E: Você não vê isso com romantismo. Você não vê isso como uma prova de amor? Você vê isso como algo que poderia ser evitadol

D: Amor é outra coisa. Amor é querer bem. Eu amo você, então a gente tem que ficar igual? Näo!

E: Nāo?

D: Não.

E: $O$ amor é poder ser diferente?

D: O amor é poder zelar pela outra pessoa. Não querer o mal da outra pessoa, entendeu?" (p. 10-12)

Dia relata que sentia muito prazer em estar grávida e que, se não tivesse HIV, teria quatro filhos, mas, em função do HIV, solicitou que o médico fizesse laqueadura, durante a cesárea de seu último filho.

"D: Quando a mulher quer ter um filho, enquanto não consegue o nenê, não sossega, né? Eu ficava falando vamos ter outro nenê...Vamos?

E: E o qual faz uma mulher ter um filho, o que faz ela ter esse desejo do ter filhos?

D: Ah é gostoso.

E: É gostoso?

$D: E$, um barrigão bonito.

E: As pessoas te olham diferente quando você está grávida?

$D:$ Ah, você fica mais bonita, mais alegre.

E: Eu imagino que se vocé tem essa visão, como deve ter sido difícil para vocé não ter podido curtir a gravidez? Vocé estava num momento que não dava para viver esse tesão, essa plenitude?

$D: E$ verdade. Ainda mais a gente assim, que gosta muito de artesanato, natureza, sabe? Ficar com o barrigão pra fora, ficar na praia.

E: Então, você pensa em ter outros filhos?

D: Não. Eu operei.

E: Porque você operou?

D: Porque eu não quis mais.

E: Não quis mais?

D: Não, é muita loucura. Foi muito traumatizante. Levar o nenê para tirar sangue...

E: Foi oferecido pra você?

$D:$ Não, fui eu que pedi.

E: Foi na cesárea.

D: Foi.

E: Você fez o parto e logo em seguida a laqueadura?

$D$ : Já aproveitou a anestesia e já fez a laqueadura. Eu não queria mais.

$E$ : Mas você acabou de falar o quanto é gostoso...Do quanto isso é bonito e que você não viveu isso do jeito que você queria da segunda gravidez e aí, e agora como vai ser?

$D:$ Agora não vai ser. (risos)

E: Você abriu mão desse prazer? 


\begin{abstract}
D: Abri.
E: Você queria ter dois filhos?

D: Não, para o meu prazer, eu queria quatro.

E: Abriu mão de dois, ficou com dois.

D: Vai ser possivel cuidar de dois. Dols pra mim já é dificil, imagine quatro? Ai eu falei, vou parar por aqui, né? Você está mexendo com a vida de outra pessoa. Tudo bem, deu certo o tratamento, mas podia não ter não dado certo, né? Então eu não estava querendo viver de novo outra gravidez.

E: Então a gente pode dizer que o fato do HIV ter acontecido para você influenciou na sua decisāo de ter um filho?

D: $\operatorname{Sim}^{\prime \prime}($ p. 16-17).
\end{abstract}

Dia acredita que não terá problemas para contar sobre o HIV para seus filhos e que, o fato de que ela é uma mãe vivendo com HIV influenciou, de certa forma, positivamente, pois ela se tornou uma pessoa "mais ajuizada". Entretanto, essas mudanças pessoais, também, tiveram repercussão em sua vida afetiva, pois ela decidiu que não é possível envolver-se, seriamente, com outra pessoa.

Outro aspecto, que chama atenção, é o fato de ela ter afirmado, claramente, que pretendia ter quatro filhos e a descoberta do HIV fez com que ela "optasse" por uma laqueadura, aos 29 anos, com dois filhos. Ela confessou que "abriu mão do prazer de engravidar", em função de ser soropositiva. Embora ela aponte que o olhar que o outro tem, sobre o fato de ela ser soropositiva e mãe, seja um olhar preconceituoso e de julgamento, ela, também, é categórica quanto à questão: para ela, um casal soropositivo ou sorodiscordante não deve ter filhos, pois o risco de ter um filho soropositivo, embora baixo, é algo que deveria determinar a desistência de serem pais. Ela discorda da posição de casais, que "bancam" o risco de terem um filho soropositivo, ou de casais sorodiscordantes que tentam engravidar.

Para ela, as decisões que o outro tem que tomar devem envolver apenas aspectos objetivos, mas ela se esquece de que suas próprias decisões foram tomadas, dentro de um contexto "subjetivo", em um momento, que ela mesma define "como muito doido". Embora ela procure tomar uma posição prática, quanto a si mesma (toma juízo, faz laqueadura, não se envolve com outra pessoa), uma série de questões subjetivas, que causam sofrimento, permanecem pendentes e intocadas. Podemos pensar que se " $O$ amor é poder zelar pela outra pessoa. Não querer o mal da outra pessoa", permanecem questōes sobre seu relacionamento com o marido, que desistiu de lutar contra a doença e a deixou sozinha, não zelando por ela e seu filho. Ela tinha informações sobre HIV e grupos de risco e, mesmo sabendo que seu marido era usuário de drogas injetáveis, e que havia o risco de doenças, ainda assim, isso não a impediu de engravidar. Como zelar pelo outro, ou ainda, como zelar por si mesmo, quando o próprio sujeito não quer, ou não pode, posicionarse perante seu desejo inconsciente? 
6.1.9 - Sílvia: que, antes da gravidez, "não ligava pra nada" e, agora, vive em função da filha

Síntese: Aos 22 anos, mora com sua mãe. Descobriu que era soropositiva, aos 16 anos de idade. Engravidou de seu namorado (o preservativo estourou). Teve uma menina (que agora tem 9 meses e é HIV-). Ele não sabia do status sorológico de Sílvia. Após a gravidez, Sílvia mudou completamente: deixou de usar drogas, voltou para a casa da mãe e passou a se tratar.

Figura 16 - Diagrama da linha narrativa relativa à entrevistada Sílvia

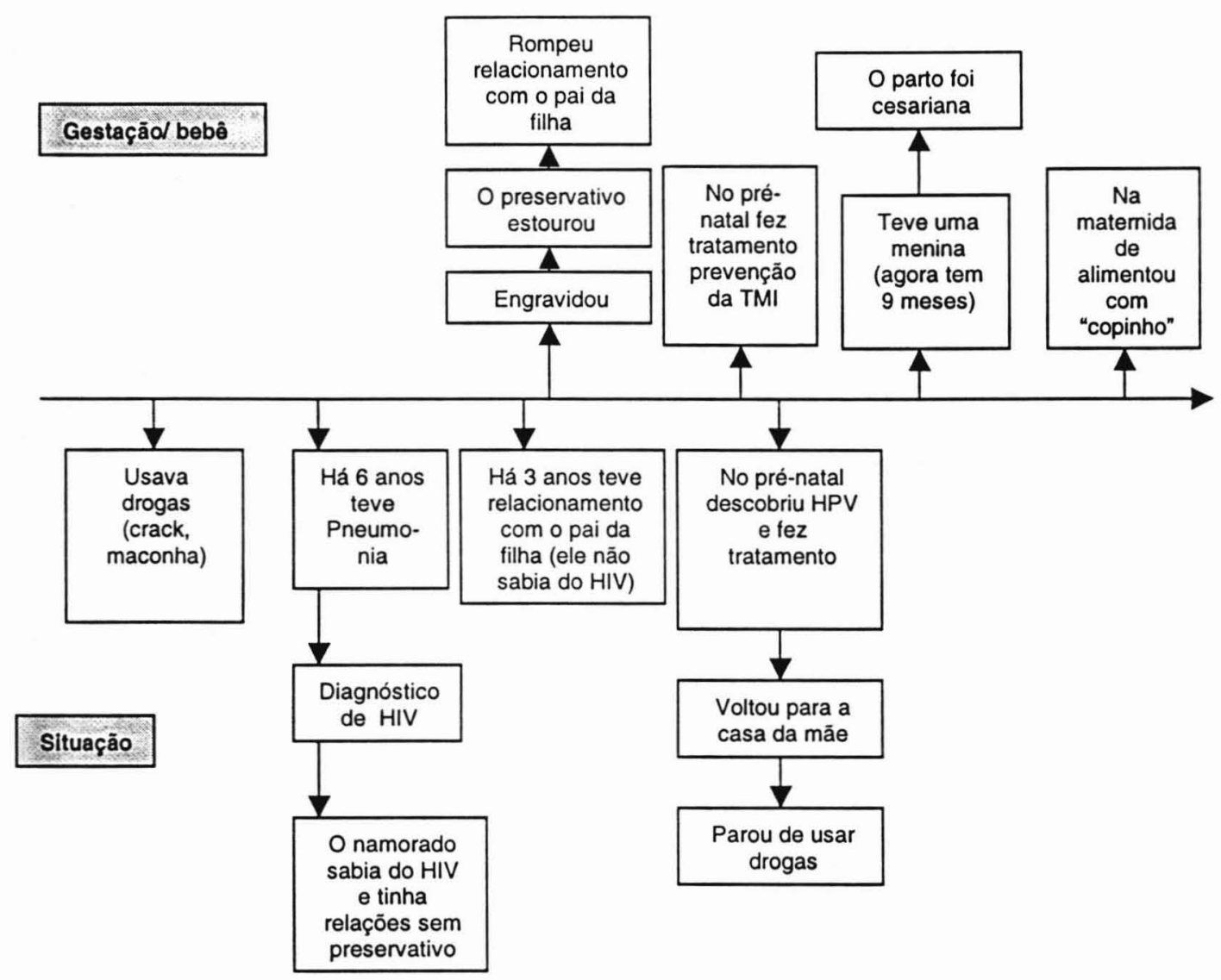

Sílvia trabalha em um "barzinho como garçonete" e mora, atualmente, com sua mãe. Contou que usava drogas (maconha e crack) desde os doze anos, era muito "rebelde" e fugia de casa. Ela acredita que foi infectada, mediante relações sexuais com um namorado que, apesar de saber que era soropositivo, não contou sobre o HIV, e se recusava a usar preservativo. Quando Sílvia decidiu romper o namoro, ele a ameaçou. 
"Quem passou para mim, falou pra mim. Eu não quis mais ver ele e ele disse que ninguém ia me querer mais porque eu tava com essa doença."

Há seis anos, Silvia ficou doente, com um quadro grave de pneumonia, quando procurou a ajuda de sua mãe. Foi internada e descobriu que tinha o HIV. O médico do posto de saúde mostrou-se bastante interessado em ajudá-la e chamou sua mãe para conversar, pois Sílvia era menor de idade. A atitude do médico foi protetora, procurando orientá-la a se comportar melhor. Apesar dos conselhos, Sílvia não parou de usar drogas, nem deixou de fugir de casa. Ela acreditava que, por ter contraído o HIV, não poderia ter filhos, pois temia transmitir o vírus para alguém.

"S: (...) eu nunca pensava que eu ia ficar grávida. Eu já tive um namorado antes e ele era louco para ter um filho, mas eu não conseguia.

E: Por que?

S: Não seil (resposta enfática)

E: Por que você queria ter um filho?

S: Ah, eu tinha o maior desejo, ai, depois que eu fiquei, que eu peguei o HIV, eu pensei que não ia poder ter.

E: Por que pensou isso?

S: Ah, eu cismei. Eu não fazia o sexo, eu achava que passava a doença para alguém.

E: A tua preocupação era passar a doença para alguém durante a relação sexual?

S: É. Pra mim tudo bem, mas e a minha filha? E a outra pessoa? Al eu pensava que nunca na minha vida ou ia poder ter filho. Eu colocava isso na minha cabeça".

Há, aproximadamente, três anos, iniciou o namoro com o pai de sua filha, que desconhecia sua situação sorológica; eles usavam preservativo, de maneira constante, até que, um dia, o preservativo estourou.

"E: Então você comę̧ou esse relacionamento com esse companheiro e al um dia vocés transaram sem preservativo $e .$.

S: Não, foi com...

E: O que aconteceu?

S: Ele nem percebeu que tinha estourado.

E: E você engravidou e como foi?

S: Não desceu pra mim e eu sabia que era ele. Só com ele tinha acontecido isson.

Antes de descobrir que estava grávida, teve um relacionamento com um homem, que percebeu que ela tinha HPV. Essa pessoa levou-a até o CR Campos Elíseos, para procurar tratamento.

"S: (...) Já tava grávida e mas eu não sabia. Tinha um cara que queria namorar comigo. Eu saí com ele e na hora $H$ elo viu que eu tava com HPV. Eu nem sabia o que era isso. Nunca tinha feito papanicolau nem nada. Al ele pegou $\theta$ me levou lá no Campos Eliseos.

E: E lá eles te encaminharam para cá (Avaids). Você estava grávida de quantos meses?

S: Acho que dois ou três. Aí quando eu cheguei lá, ela pegou e me examinou, fez exame de sangue, tal. E deu no exame que eu tinha Aids. Eu sabia que eu já tinha, mas foi para confirmar. Ai ela falou que não podia me cuidar porque eu 
tava grávida. Pediram exame de urina. Fiz o exame e deu positivo a minha gravidez".

A gravidez de Silvia trouxe mudanças significativas em sua vida: ter procurado a ajuda de sua mãe, ter deixado de usar drogas e, finalmente, ter iniciado o tratamento do HIV, de forma mais efetiva.

\begin{abstract}
"Agora é, tipo, totalmente diferente, porque, tipo, quando eu usava droga eu era acabada, entendeu? Não queria saber de nada, depois, mas antes de eu parar eu já tinha muita coisa... Mas depois que eu voltei para casa, que eu fiquei doente, que eu descobri, eu já sai de casa por um més, entendeu? Eu queria entrar e entrava. Não fiquei nem três dias na rua e já usei. Fiquei três anos $\theta$ pouco e depois de me acostumar e parar, entendeu? Assim, de usar droga. Eu já tava sentindo que eu não ia usar mais."
\end{abstract}

O tratamento para prevenção da TMI não causou nenhum problema para Silvia, pois ela afirmou que havia incorporado a tomada de remédios, como algo que fazia parte de sua vida.

"E: E como é que foi tomar a medicação e estar grávida?

S: Normal.

E: Você conseguiu tomar direitinho?

S: Muita gente fala, por causa do nenê... Mas pra mim não tem nada disso. Pra mim é normal.Tomar os remédios já é meu dia-dia. Já estou acostumada, mas tem gente que não gosta".

Durante o pré-natal, continuou o controle da infecção pelo HPV. Foi orientada que, em função disso, o parto deveria ser cesariano. No dia do parto, Sílvia percebeu que a equipe procurava por alguma coisa. Foi, então, que ela "se lembrou" de que tinha levado o kit, para prevenção da TMI. Houve, também, uma situação de preconceito explícito, por parte da equipe de enfermagem.

"S: (...) Em seis (enfermeiras) teve uma só que me tratou assim... sabe, eu me senti discriminada. Na hora de ter o bebé, tinha uma que tipo, não gostava de pegar em mim, entendeu? Dava para ver...

E: A enfermeira?

S: É. Quando eu tive o bebé eu tava toda anestesiada, como que eu ia passar para a maca. Toda suja de sangue, mas não dava. Eu tava morrendo de frio. Ela tava mandando eu passar para a macal Ficava mandando. Aí eu falei assim: mas como é que você quer que eu passe? Eu não consigo. Ai que veio outra e que me ajudou. Ela falou "vocé não está vendo que ela está anestesiada e não consegue passar?"

E: Você sentiu que a outra enfermeira não queria te tocar por causa do sangue. (ela assentiu). E você estava no quarto?

S: Não eu tava passando para a maca no corredor".

Outro aspecto, que chamou atenção, em seu discurso, foi a situação de alimentação do bebê no pós-parto. Ela contou que alimentou seu filho com um "copinho", uma vez que, naquela maternidade, "não podia entrar mamadeira".

"E: E como é que foi para dar de mamar?

S: Ninguém falou nada para mim. Ninguém sabia, mas na hora foi no copinho (risos).

E: Copinho? 
S: Foi no copo. Lá não podia entrar mamadeira. Aí ela tomava no copinho.

E: Não podia entrar mamadeira? Por que?

S: Acho que é por causa que a mamadeira já era de lá, entendeu? Eu não levei mamadeira. A mamadeira que me deram para dar mamar para minha filha era de lá. Por causa do bico, ficava chupando, outras crianças... Eu acho que...

E: Eu não entendi...

S: Não é... só de lá que pode usar. Não pode levar. Af lá não tem bico na mamadeira. Aí tem que tomar no copinho.

E: Tinha mamadeira mas seu bebê não podia tomar na mamadeira?

S: Podia. Pode usar. Tinha muitas mamadeiras, que eles levaram, mas não tinham bico, entendeu?

E: Cada mãe tinha que levar o seu bico?

S: Não. Não pode entrar bico.

E:Então como é que tinha mamadeira e não tinha bico?

S: Então. Tinha que dar no copinho. Porque tem que esterilizar a mamadeira...

Tem muito trabalho, então não tinha mamadeira. Não deixava entrar.

E: Al seu bebé, recém nascido, teve que mamar no copinho da mamadeira?

S: Mas ela aceitou direitinho...

$E: E$ as outras mães amamentavam..

S: Amamentavam.

E: E como é que você achou disso?

S: Ah, eu não senti diferente porque já me orientaram. Falaram que eu não podia. Aquilo ali era para o bem do meu filho.

E: Você tinha leite?

S: Tinha.

E: Foi dado uma medicação para secar? (ela assentiu com a cabeça)

S: É. Não podia dar de mamar!

E: Mas pelo que eu entendi, isso não te causou um problema. Você foi orientada e entendeu e tudo bem. E até dar o leite no copinho não foi um problema. Porque eu estou achando muito estranha esta estória do copinho...

S: Me orientaram depois. Porque tem mãe que não tem leite mas dá no copinho também. Também vieram me perguntar porque eu não dei leite materno de outra pessoa. Mas eu não sei disso não".

Mas, o fato de não poder amamentar causou certo desconforto para Sílvia, pois ela viu necessidade de inventar alguma "desculpa" para as pessoas.

"E: (...) Você estava contando como foi alimentar seu bebé. Eu tive retomando na fita que vocé deu no copinho e depois deu mamadeira. Depois que saiu do hospital. E como é que foi a situação de não amamentar?

S: Me senti assim diferente das outras. Eu via assim elas amamentando e eu tinha que inventar, né?

E: E o que você contou?

S: Eu falei que... não sei. Que eu tinha, que eu tava com... Elas perguntaram porque eu não podia amamentar e eu disse "não sei, eu devo ter alguma coisa, né?"

E: Vocé desconversou

S:É.

$E: E$ você com você. Como é que você sentiu isso?

S: Eu uma hora assim inventava que eu não tinha leite, que não tava dando para sustentar ela e por isso tinha que dar o leite no...entendeu?

E:Mas vocé ficou chateada de não poder amamentar?

S: Fiquei um pouco. Porque, sei lá. A gente se sente diferente. Você as pessoas amamentando o filho e você não pode? Mas se for pro bem, né?" 
Havia preocupação quanto à possibilidade de que sua filha pudesse ter nascido com o vírus, e o fato de participar de grupos de mães, que viviam situaçōes próximas à sua, possibilitou que ela se sentisse mais confiante e segura.

"E: Podia fazer isso para ajudar,né? E aí você ficou com a preocupação do bebê, que a sua filhinha podia ter o virus?

S: Fiquei. (ela ficou com expressão séria)

E: Como é que foi? $E$ ai você teve um período, ficou 9 meses fazendo exames.

Como é que foi essa expectativa, vocé estava preocupada? E se ela tivesse o virus?

S: É. (pausa). Se ela tivesse... O que eu pude fazer por ela, para ela não ter nada, eu fiz, né? Se ela tivesse... fazer o que né? Vai ter que se cuidar do mesmo jeito que eu me cuido.

E: Pensou na possibilidade dela ter o virus $\theta$ acho que OK. Vamos cuidar.

S: Fora que eu convivia com as pessoas que tem seus filhos, vão no posto e tal. Eu ia direto lá, né? De semana em semana eu ia. Porque eu tava com HPV e me examinava direto. Mas não tinha por dentro, entendeu? Al elas falaram para mim que ia dar tudo certo, que muitos negativaram, né? A minha também tinha essa chance.

E: Ai você se animou?

S: E."

A experiência da maternidade parece ter se configurado como algo determinante na vida de Silvia. Ela havia abandonado a idéia de ter um filho e, a partir da gravidez, pôde posicionar-se, de uma forma diferente, perante a vida.

"E: E como é para você essa experiência de ter um filho?

$S$ : Ah, maravilhosa. (risos). Sei lá. Minha filha é tudo pra mim.

E: Sua filha é tudo pra vocé.

S: Se eu vivo mesmo é por causa dela porque senão eu acho que eu não tava nem ai com a vida."

(...)

E: Te emociona isso não é...E ser mãe, como que é ser mãe?

S: Tipo muda, né? Tipo muda tudo porque fica mais responsável. Uma coisa que você nāo faria nunca, agora faz. Tipo, eu saía muito agora não saio. Tudo que eu faço é para minha filha. É bem diferente. Quando você é mãe, tudo muda."

(...)

"E: Você acha que junto com esse bebê que nasceu, nasceu também uma nova Silvia?

S: Nasceu."

Silvia relatou uma série de "ganhos", que a gravidez proporcionou: apoio familiar, social e institucional; recuperação da saúde; sentimento de completude e beleza (possibilidade de retomar seu relacionamento com o pai da criança), entre outros. A experiência foi tão interessante, que ela afirmou planejar ter outros filhos, preferencialmente, um menino. $O$ fato de ser mãe e soropositiva não parece ter causado tanto impacto em sua vida. A percepção que Sílvia supõe que sua filha terá dessa situação, é que a criança será grata à mãe por ter assumido uma série de cuidados, para evitar que ela tivesse o vírus. Ela acredita que haja preconceito, por parte da sociedade, sobre a sua 
decisão de ser mãe e soropositiva, por isso, ela prefere manter segredo quanto ao seu estado sorológico.

A descoberta do HIV não constituiu um significante que the proporcionasse contato com sua falta constitutiva, pois ela se via completada por um gozo, em curto-circuito, em função do uso de drogas. Nesse sentido, a proposta do médico, que pretendeu orientá-la a voltar para casa e a "se comportar", apesar de bem intencionada, mostrou-se ineficaz. Esse tipo de intervenção não tocou em seu ser, ficando como algo moralmente indicado. Silvia não parece ter problemas em saber discernir, moralmente, o que é bom do que é ruim. Ela demonstra, na verdade, encontrar-se em uma posição de gozo, de tal forma fechado, que exclui qualquer escolha de ordem moral, ou seja, que perpasse o laço significante (próprio do grande Outro). Não parece que ela tenha a intenção de "magoar propositalmente" a mãe ou qualquer outro. As pessoas diagnosticaram que ela foge de casa "para chamar atenção", mas parece haver, além disso, um gozo não simbolizado, que vai além do dito.

Embora Silvia não assuma uma posição de responsabilização sobre a atitude de "se deixar engravidar", fica evidente, a partir de seu relato, que a experiência da gravidez constitui uma mudança, que possibilita que ela cuide de si, mas mediante o cuidado do outro. Quando nasce sua filha, nasce, também, uma nova Silvia. É interessante perguntar: afinal, quem é mãe de quem?. Se for assim, quem se responsabiliza por quem? Que tipo de pacto inconsciente aí se encerra? Quando Sílvia afirmou que "se eu vivo mesmo é por causa dela (a filha) porque senão eu acho que eu não tava nem aí com a vida", não podemos deixar de escutar que a filha assume um lugar de tamponamento da falta, ou seja, um lugar de falo. Antes da gravidez, Silvia vivia uma parceria sintomática com as drogas e, embora a gravidez tenha despertado um outro tipo de relação, trata-se de algo muito colado à experiência com o Real (de gozo) no corpo. 
6.1.10 - Débora: que se sentia culpada e culpava seu companheiro, porque pensava que tinham infectado o inocente que carregava dentro dela.

Sintese: Tem 30 anos de idade, é recepcionista e tem um filho de um ano e dois meses (HIV-). O diagnóstico de HIV ocorreu há 10 anos, quando seu noivo, na época, adoeceu e faleceu. Há seis anos, iniciou um relacionamento com o pai de seu filho (também HIV+) e ele decidiu que teriam um filho. Ela engravidou e acreditava que seu filho seria HIV+, impreterivelmente. Após receber orientação médica, sentiu-se menos angustiada. Separou-se do pai de seu filho e, há seis meses, iniciou outro relacionamento.

Figura 17 - Diagrama da linha narrativa relativa à entrevistada Débora

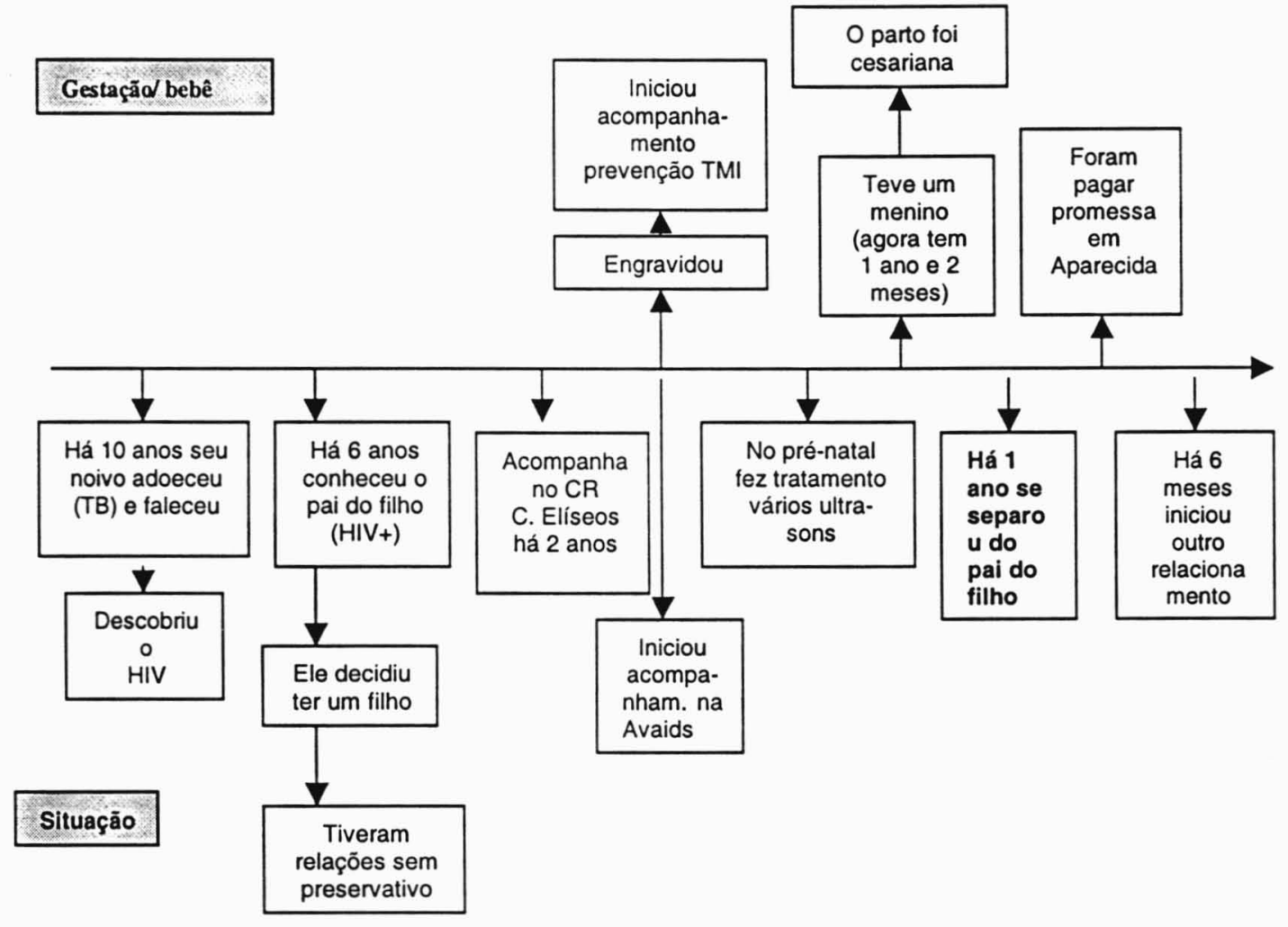

Débora teve um filho, aproximadamente, nove anos após a descoberta do HIV. Seu bebê tem um ano e dois meses de idade. Há seis meses, ela iniciou um novo relacionamento com uma pessoa que, também, é soropositiva. Ela contou que conheceu o pai de seu filho, há seis anos.

"É mais fácil estar convivendo com uma pessoa HIV também. Mais fácil estar te aceitando, não vai ter aquela coisa de te julgar, jogar na cara... Disso e daquilo..." 
Débora acreditava que, pelo fato de ser soropositiva, se ficasse grávida, teria, impreterivelmente, um filho soropositivo. Em função disso, havia abandonado a idéia de ser mãe. Ao iniciar o relacionamento com seu companheiro anterior (o pai do seu filho), ocorreram situações de cobrança social (ninguém, além dela e seu marido sabiam da situação sorológica do casal), o que colocava o casal em uma posição delicada.

\begin{abstract}
" $D$ : Eu achava que se engravidasse o bebê já era... Que ia ser um sofrimento maior tratar de uma criança com aquilo, ia ter sempre aquele peso na consciência, que tinha contaminado meu bebê. Então era uma coisa que eu não queria. Meu marido, na época, uma coisa que ele queria muito era filho, mesmo sendo portador como eu. A familia dele cobrava muito um filho nosso, a minha familia também cobrava muito. As minhas amigas, em festinhas de criança, a gente ia sempre só os dois. E todo mundo "E o bebê, ainda nada!".

E: Vocês ficaram juntos quanto tempo mesmo?

D: Seis anos. Todo ano, na festinha era a mesma pergunta".
\end{abstract}

A decisão de ter um filho foi, de forma mais determinada, de seu companheiro. Mas Débora admite que havia, nela, também, algo que a mobilizava nesse sentido.
"E: como é que foi a sua decisão de ter um bebê?
D: Não foi minha. Ele sempre quis.
E: Ele também era portador?
D: É. Eu nunca quis pelo medo disso. Assim que caisse o esperma delo lá dentro de mim, meu bebezinho já tava infectado. Eu tinha isso na cabeça. Nunca me preocupei em ficar me informando sobre gravidez, nem sonhava em ser mãe, por causa do HIV. Eu achava que ele já ia ser automático HIV, então eu não queria, mas ele queria de todo jeito e ele falava "não, vamos ter um bebếl" $A$ gente tem que ter, a gente cuida, do jeito que ele nascer a gente aceita e a gente cuida, vamos de todo jeito. Mas ou meu medo era esse.
E: Ainda assim ele queria?
D: Queria, o sonho dele era ser pai. No fundo, no fundo eu queria ser mãe, porque eu tinha inveja das minhas colegas, da minha irmã. No fundo, no fundo eu tinha uma vontadezinha, mas tinha medo.
$E: E$ antes de vocé engravidar, como é que vocés evitavam?
D: Eu tomava anticoncepcional e usava camisinha. Por via das duvidas, tomava anticoncepcional.
$E: E$ como é que apareceu o nenê?
D: Ele me convenceu! (risos)
E: Tipo, vamos correr esse risco?
D: Uma vez só, uma vez só. Foi uma vez só que nós não usamos camisinha, eu não tava tomando remédio e eu tinha certeza. Sabe quando vocé sente que caiu lá dentro? Eu tinha certeza absoluta."

A gravidez de Débora pode ser caracterizada por dois momentos distintos: antes e depois de receber a informações sobre a possibilidade de prevenção da TMI (de que havia chances de que seu bebê pudesse nascer soronegativo). Enquanto Débora não tinha tido acesso às informações atualizadas sobre o risco da TMI, ficava imaginando que seu filho nasceria com o vírus e, assim, passou a culpar seu companheiro. Relutou alguns meses para esclarecer suas dúvidas com a médica que a acompanhava. Vivenciou intensa angústia, nesse período, e, ainda assim, continuou firme em sua decisão de levar a gravidez adiante. A ansiedade parece ter diminuído, após ter recebido 
as informações médicas, mas persistiam as fantasias quanto à saúde da criança.

"E: Como é que foi para você, ser portadora do HIV imaginando que sendo portadora do HIV, o bebê vai pegar o HIV?

D: Ah, eu chorava muito, arrumava discussão com ele por tudo e me sentia culpada porque eu tava com um bebê dentro de mim e que eu tinha passado... nós tínhamos passado o HIV para aquele inocente. Al eu culpava ele e dizia "você que quis e eu não queria", aquela ferveçāo de grávida, tudo acaba chorando... E a primeira coisa que eu usava era isso.

$E: A h$, então ai tem um outro aspecto que você está levantando, que grávida também já fica sensivel pra caramba!

D: Eu não me suportaval (risos). Tinha dia que eu não agüentava ele, xingava ele. Tinha dia que eu estava só amor e carinho, tinha dia que eu estava só chorando e tinha dia que eu tava só dando risada.

E: Você acha que este estado "sensivel", vamos assim dizer, ficou ainda mais exacerbado pela questão do HIV?

$D: E$, foi. Até quando cheguei lá pelo sétimo, oitavo mês, que aí eu já estava mais esclarecida. Ai parou mais."

(...)

E: Tá, mas e quando ele apareceu, quando vocé realmente engravidou, $\theta$ a possibilidade de ter um filho infectado?

D: la criar, ia amar, fazer o que?

E: Tá, isso é um fato. Mas como você sentia isso? Tá, nasceu infectado, vamos imaginar isso. Como que é para você a possibilidade de ter um filho com HIV?

$D$ : la ser triste.

E: $\dot{E}$ triste, mas?

D: Eu ia cuidar..

E: Nāo te impediria.

D: Nāo... porque assim..

E: Vocé aceita o HIV? É isso?

D: Nāo. Porque assim, hoje em dia está tão avançada a coisa que a criança pode estar negativando até os seus dois anos. Pode tomar remédio bonitinho, já mamou, carinho igualzinho a uma outra criança que não é positiva, tudo isso.

E: Então, é isso que eu estou to perguntando, como é que seria se ele não tivesse negativado. Você acha que modificaria muito a maneira como você sente com ele? ?

D: Não. Acho que ia amar mais. Acho que ia amar em dobro. Porque mãe já ama, mãe já é doente pelo filho. É o dobro".

De maneira geral, Débora referiu que a atitude da equipe, que a acompanhava, foi de acolhimento e apoio.

"D: Eu já era bem tratada e fui melhor tratada ainda por todos. Depois da gravidez, me pegaram no colo, todo mundo, com toda a atençāo voltada para mim e para o meu bebê, bateria de exames direto, mais bem tratada ainda.

E: Tem uma coisa que a gente estava falando antes e que é até interessante registrar, que você falou da luz, você se sentiu com luz. Vocé arrumou psicológico, né?

D: Muita luz.

E: E você acha que o psicológico vem da onde, esse primeiro abalo, do fato de se saber grávida e ser soropositiva?

$D:$ Por estar portando um inocente dentro de você e que está dependendo de você para vir ao mundo bem ou não."

O relato de Débora mostra que a situação da gravidez a colocou em contato com conteúdos bastante regressivos, acionando mecanismos de 
defesa do ego, como negação, deslocamento, entre outros. Mesmo após receber informações sobre o tratamento, para prevenção da TMI, ainda assim, persistiam angústias relativa à suposição de que as medicações tomadas poderiam fazer mal para a formação do bebê.

"D:(...) Fazer um ultra-som uma vez por més, para ver se tinha... se tava perfeito. Ai me pediram vários ultra-sons morfológicos, que era para ver se tava tudo bonitinho, tudo perfeitinho e controlando esses remédios. Perguntavam o que eu sentia. Minha preocupação maior era essa, dele nascer positivo e defeituoso. Então eu me preocupava muito em estar sabendo dos ultra-sons morfológicos, para saber se ele estava perfeito. Eu queria um bebê perfeito. Ai, rezava muito, pedia muito a Deus que acontecesse qualquer coisa comigo, mas com o meu bebê não. Tudo o que me mandavam fazer eu fazia. Mandavam eu ir no fim do mundo e eu ia.

E: Vocé lutou mesmo para que tudo desse certo.

$D$ : Que ele nascesse perfeito e negativo.

E: Mas deve ter sido difícil, mesmo com as pessoas te orientando, dizendo que tem uma chance boa de dar tudo certo, do bebé estar bem e não ser infectado, é complicado, porque pelo o que eu estou entendendo é complicado ter que tomar medicação.

D: E. Porque normalmente uma mulher grávida não pode tomar isso e aquilo.

$E: E$ você ficava num dilema.

$D$ : É exatamente por isso que minha infecto trocou a medicação. Ela falava "Ah, mãe, esse aqui é 10 para gravidez, esse aqui é ótimo. Esse aqui ajuda demais e não vai afetar em nada"."

(...)

"Eu tava fazendo a ultra-som com receio antes e enquanto ela esta passando ali e dizendo "ah, a mãozinha está assim bonitinha, o coraçāo tá assim também bonitinho", nossa você vai assim tirando aquele peso, vai saindo peso das suas costas, vai saindo peso da sua consciência."

O relato do nascimento de seu filho foi bastante detalhado, ressaltando o aspecto doloroso da situação e do sofrimento solitário do parto. A questão da alimentação do bebê, no pós-parto, gerou uma situação inesperada:

"E: Como foi alimentar o bebê?

D: Ele já vinha alimentado para mim.

E: Com o que ele era alimentado?

D: Leite, leite deles que eles davam lá. Não sei qual leite. Ele já vinha amamentado e sempre na mamadeira estava escrito... é...(pausa) "mãe não amamentar"

E: Estava na roupa dele.

$D: E$, estava sempre na roupa dele.

E: Vocé tinha leite?

D: Não. Secou.

E: Foi com medicação?

D: Eu tomei depois que eu tive ele. Eu já fui pro quarto seca. Eu acho que a coisa da minha cabeça foi tão grande, o medo de ter o bebê. Secou. Eu saí da maternidade, quando eu tive alta, secal $E$ eu fui para a maternidade com o peito assim (mostrou as mamas como se estivessem grandes). Eu apertava assim e saia. Quando eu tive o bebê que eu fui pro quarto, foi impressionante. Foi coisa de Deus mesmo. Já que ela não vai poder amamentar, deixa eu tirar, né? E secou."

Logo que o bebê nasceu, constatou-se que era negativo para HIV, mas ele continuou a tomar o xarope de AZT. Aos seis meses de idade, foi realizado 
um novo exame e, ao confirmar que ele não tinha o vírus, houve grande alivio para a família, que foi "pagar promessa em Aparecida". A possibilidade de que o bebê nascesse com o vírus levava Débora a caracterizar a maternidade como algo difícil. Ser mãe é algo passional "Nossa, mãe mata ou morre. Toda mãe é sotredora, acolhedora, a que ama mais".

A possibilidade de ter um filho soropositivo parece ser algo difícil, mas que pode ser manejado, em virtude dos tratamentos disponiveis. Há uma preocupação extra: ter que estar disponivel e saudável para cuidar do outro, caso ele necessite. Para Débora, o "ser mãe" é um processo, um aprendizado. $\mathrm{Na}$ verdade, há um "tornar-se mãe". Mas esse aprendizado envolve sacrifícios e, principalmente, dedicação incondicional.

Débora decidiu não contar sua situação sorológica para a família. Acredita que sua decisão de ter um filho, sendo soropositiva, é absolutamente pessoal, não importando a opinião das outras pessoas.

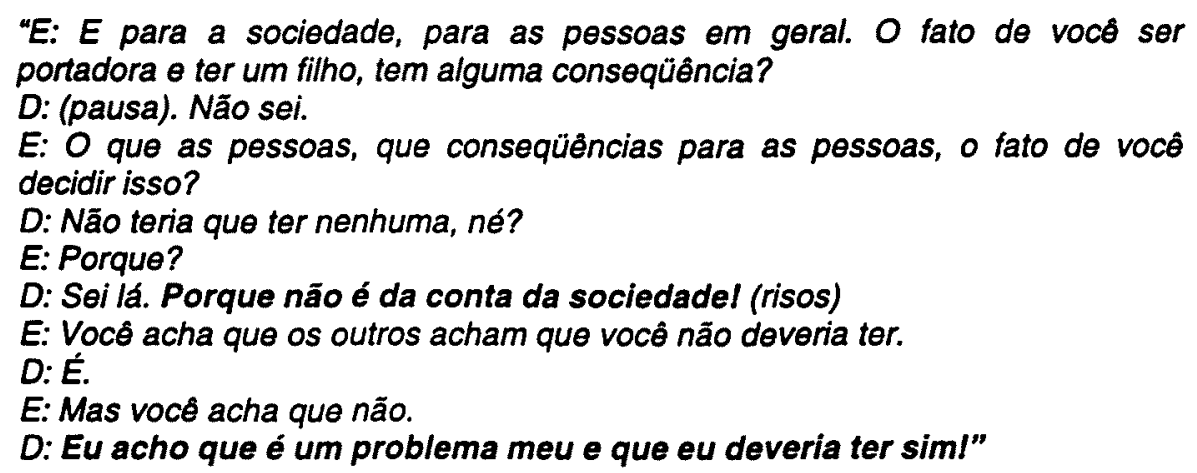

Embora se posicione dessa forma, ela afirmou, categoricamente, que não pretende ter outros filhos e que faz uso constante de preservativo, como método contraceptivo. Débora revela, também, que seu filho terá acesso às informações quanto ao seu estado sorológico, e que não sabe dizer se esse fato the trará alguma conseqüência.

"E: E pro seu filho, tem alguma conseqüència vocé ter decidido tê-lo sendo portadora do HIV?

D: Não sei, acho que não. Porque quando chegar na idade, eu pretendo estar passando tudo para ele.

E: Al vocé pretende conversar com ele.

D: Pretendo. Porque ele vai ver remédios, vai ler receita. Ele vai ver... ele vai perceber a coisa diferente. Eu quero estar falando com a minha boca."

Débora parece muito interessada em acompanhar, de perto, seu tratamento, conhecendo sua situação clínica e esclarecendo suas dúvidas. Participa das reuniōes na Avaids e diz beneficiar-se bastante, não apenas pelo fato de receber o leite para alimentar seu filho, mas, também, por poder encontrar, naquele lugar, um espaço onde pode lidar com o "caos" que o HIV significa na vida de uma pessoa. Afirmou que a gravidez foi um momento de "de muita luz" e realização, o que lhe permitiu uma transformação pessoal. 
A decisão de ter o filho, apesar da sua concordância, foi do seu companheiro. Ele pediu, ele decidiu. Coube a ela, apenas, 0 ato de concordar, de se fazer objeto de desejo do Outro/outro. Assim, satisfazendo o desejo dele, recebia uma parcela dessa satisfação, sem, entretanto, ter que assumir qualquer responsabilidade por essa escolha. Tal situação parece indicar que Débora não pôde, ou não pode, responsabilizar-se pelo próprio desejo e encontrou uma estratégia para contornar essa questão: ela deseja o desejo do outro. Trata-se de uma posição histérica. "No fundo, no fundo eu queria ser mãe, porque eu tinha inveja das minhas colegas, da minha irmã. No fundo, no fundo eu tinha uma vontadezinha, mas tinha medo".

Quando Débora comenta que "as pessoas", também, cobravam que ela tivesse filhos, ela parece usar da mesma estratégia: não é ela quem deseja, são os outros que desejam por ela. Débora assume, então, o suposto desejo do Outro (grande Outro). Não podemos deixar de levar em conta que toda estratégia, que visa a uma barganha com o desejo, só vai fazer com que o Real se presentifique, de forma ainda mais intensa. O sujeito constrói uma narrativa imaginária, para tentar explicar sua conduta ou sua história, mas a angústia, que não pode ser tamponada com esses arranjos, muitas vezes, retorna, sob a forma de sintomas. No caso de Débora, ela afirmou que ficou ainda mais sensível, procurando brigas, culpando seu companheiro, como se não tivesse nada a ver com a decisão de ter um filho. Ela se coloca no lugar de vítima da situação, incapaz de assumir a responsabilidade pelo seu desejo.

Embora Débora se valha de uma expressão, relativamente comum, para caracterizar o ato de ser mãe ("mãe é doente pelo filho"), não podemos deixar de notar, ao nos referenciarmos na teoria psicanalítica, que tal escolha não é, simplesmente, arbitrária. O significante representa uma escolha inconsciente, que posiciona o sujeito em relação ao Outro (relação entre o dito e o dizer). Se, ser mãe é ser "doente pelo filho", podemos tomar esse significante como algo que indica o ponto trágico da situação: Débora é efetivamente "doente" (ela é soropositiva, o que, embora, atualmente, não se constitua como uma doença, propriamente dita, pode apontar para uma questão de saúde, ou da perda de um estado saudável). Podemos levantar a questão de que, talvez, ela tenha elaborado a fantasia de que ela, enquanto mãe amantíssima, doente e sofredora, pudesse poupar seu filho de um destino parecido com o seu. Não seria aí, mais uma vez, um auto-sacrifício, para garantir que o outro possa manter-se incólume? Débora se sacrifica e oferece seu corpo para gerar um filho. Esse apanágio de sofrimento parece, assim, caracterizar a maternidade, mas, não de maneira puramente masoquista: o que se conquista, a partir dessa posição, parece ser um lugar especial, em relação ao desejo do outro/Outro. Sai da posição de faltosa (por ser soropositiva?) e torna-se credora.

Apesar da angústia, Débora realizou todos os exames, dedicou-se intensamente ao seu projeto de produzir um rebento perfeito. Não parece, portanto, uma tarefa fácil, sobretudo, porque ela enfrentou uma série de conflitos intrapsíquicos, que se expressam, através de exacerbação de suas emoções, fantasias de que seu filho teria alguma má-formação e uma "culpa", um "peso" inesgotável, por fazer valer um desejo, que considerava interdito. 
Uma outra produção sintomática, digna de nota, é o fato de que ela contou que, apesar de ter leite, antes de o bebê nascer (o que é relativamente comum), assim que foi realizada a cesárea, seu leite secou. O corpo, enquanto representante do desejo, pode expressar aquilo que não pode ser dito. Nesse caso, o que se produziu foi um sintoma (o leite secou) que respondia à impossibilidade de amamentar. Por um mecanismo de inibição, o sintoma visa a um contorno da angústia, que ali se implica.

Seu filho nasceu "perfeito" e, após alguns meses, depois da certeza de que ele não tinha o vírus, a familia se reuniu e foi "pagar uma promessa, em Aparecida". Após a obtenção dessa "graça", o filho pode assumir, enfim, um lugar muito especial em relação ao desejo da mãe: "No meu caso, filho é o sentido da minha vida. É o que faltava para mim. Realmente é o que faltava, né?". O filho assumiu, então, a função de "completar" a mãe, de tamponar uma falta, o que, em termos freudianos, remete à inveja do pênis. Mas a completude, supostamente narcísica, da díade mãe-bebê, não é a expressão maior do feminino, pelo contrário. O que se observa, nesse processo de "tornar-se mãe", como ela mesma coloca, é uma tentativa de lidar com a impossibilidade de ser completa. Nesse sentido, o que Débora visa, com sua gravidez, é uma tentativa de se fazer completa, remetendo-a um gozo fálico. 
6.1.11 - Eliana: que não consegue montar o quebra-cabeças de sua vida.

Síntese: Tem 30 anos de idade, e é casada há 16 anos. Teve três filhos: a primeira filha tem 13 anos (HIV-); a segunda, 5 anos (HIV+) e a última filha tem 2 anos (HIV-). Foi diagnosticado o HIV, quando sua segunda filha ficou doente e foi internada. O hospital verificou que já tinham constatado HIV (no prontuário da criança) e não haviam notificado, adequadamente, a família. $O$ casal foi testado e ambos são soropositivos. Ela engravidou, pela terceira vez (o preservativo estourou), e fez o tratamento de prevenção da TMI. O casal vive um pacto de silêncio e dificuldades na relação. Eliana relata culpa e preocupação, em relação à filha soropositiva.

Figura 18 - Diagrama da linha narrativa relativa à entrevistada Eliana

\section{Gestação/ bebê}

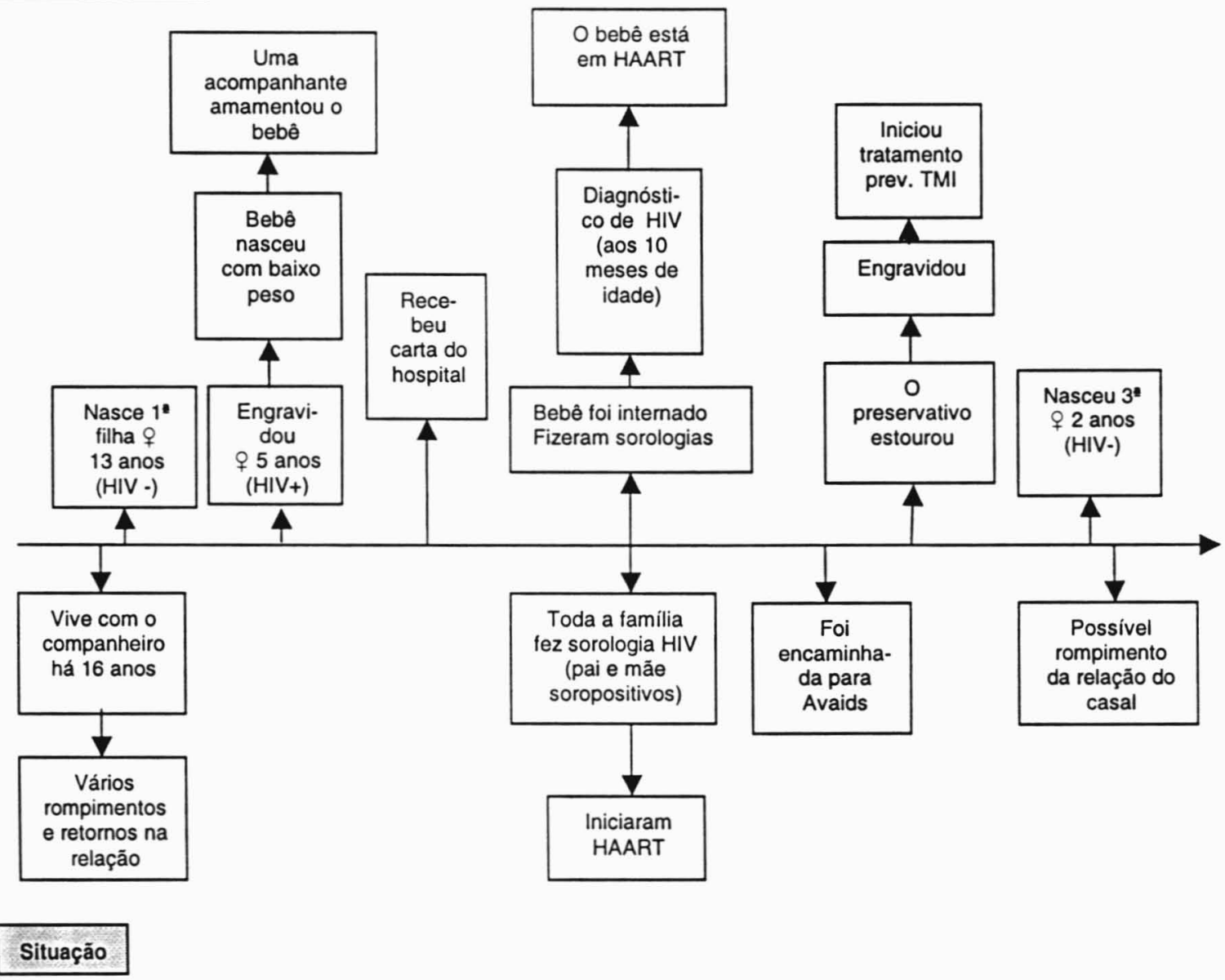

A primeira gravidez de Eliana aconteceu, quando ela tinha 16 anos. Ela teve uma menina, e pretendia tentar ter um menino, posteriormente. Em função 
disso, a segunda gravidez, oito anos depois, foi planejada, pois ela parou de tomar anticoncepcional. Nasceu, então, a segunda filha, que, com baixo peso, precisou ficar internada, causando grande preocupação aos pais. Alguns dias depois da alta de sua filha, Eliana recebeu uma carta do hospital, pedindo que ela comparecesse, novamente. Ao voltar ao hospital, Eliana precisou aguardar para ser atendida e, por sentir-se mal acolhida, decidiu ir embora para cuidar de sua filha, sem, contudo, receber a informação sobre o motivo, pelo qual havia sido chamada. Quando o bebê estava com dez meses, teve um quadro pulmonar grave e foi internado, ocasião em que foram realizados os exames sorológicos. A notícia de que sua filha tinha HIV causou grande comoção familiar.

"Eli: Foi tudo no mesmo dia. Eu estava com meu marido no dia da intemação. Eu fiquei no hospital. Meu marido foi no ponto de ônibus perto do hospital e fol para se jogar no ônibus, foi um inferno. Eu, pra mim, naquele momento a gente estava condenado à morte.

E: Vocês todos estavam condenados à morte?

Eli: Eu achava isso. Eu me sentia mais culpada por ter planejado uma gravidez, porque a Marisa foi planejada e ter acontecido logo isso com um inocente, né? Entāo ficou mais transtornado por isso, por não saber o que estava no nosso caminho. Quando eu entrei para internar a Marisa eu chorava, não escutava ninguém falar" (p. 3).

A situação da filha internada gerou grande transtorno, o que fez com que o casal se isolasse, em uma atitude de grande sofrimento e desespero. No hospital, havia um quadro que expunha a situação sorológica de sua filha, o que fez com que ela se sentisse ainda mais desconfortável.

\begin{abstract}
"Eli: Al, ela ficou internada. (...) Tinha um quadro das pacientes e do tratamento de cada um. Tinha, no caso, BCP ou BCG, que era de pneumonia. E um dia eu olho no painel, vejo as mães todas olhando diferente para mim, ai minha sogra veio e disse "vai lá dar uma olhada no quadro". Aí eu olhel e tava "Marisa, BCG+ HIV". Aquele pavilhão todinho olhava. Tinha uma sala para comer e tinha uma televisão lá, eu entrava e todo mundo sala. Eu me senti muito humilhada. Mas por filho a gente passa qualquer coisa, faz qualquer coisa, al conversei tudo. Sal do hospital, nossa, não via a hora de sair do hospital $\theta$ ir para casa. A Marisa estava tão fraquinha, tão debilitada que eu falei "é só dela que eu vou cuidar". Até hoje, mesmo se ele não precisar desses cuidados... Eu sinto assim, que ela é mais cuidada que as outras. (...) Eu achava que por eu passar como o Dr Anderson, já tava rotulado em você que você era HIV. Eu me sentia muito mal no começo" (p. 4).
\end{abstract}

Após a descoberta do HIV, a relação do casal foi se deteriorando, pois havia conjecturas sobre a forma como se dera a transmissão. Eliana concluiu que se tratava de um "quebra-cabeças".

"E: E como á que ficou tua relação com teu companheiro?

Eli: Então, ai o dia da internação, eu olhava para ele com desprezo. Eu sabia que eu nāo tinha corrido atrás pará pegar isso. Eu pensava, como eu tinha pegado isso?

(...) Al a gente saiu do hospital e ficou assim meio constrangido. Ai a gente começou a juntar peças... É um quebra cabeças. (...) Al eu falei para ele: olha vamos jogar aberto. Vocé saiu com alguém quando eu tava grávida ou depois, ou antes, de eu ficar grávida. Você pode falar... Até hoje ele jura de pé 
junto que não saiu com ninguém. Droga você não usa? Ele disse que não usou o nem usa. Então a gente liga, pela falta de informação que a Marisa teve no hospital, pode também ter acontecido alguma coisa na operação (o marido operou uma úlcera e fez transfusão sanguínea), a gente leva a crer que sim.

$E$ : $\dot{E}$ como você disse... Um quebra cabeças...Mas ás vezes falta pecas nesse quebra cabeças...(...) Mas... Do jeito que vocês ajeitaram esse quebra cabeças... Deu pra ajeitar?

Eli: Nãol (risos). Que nem, agora eu estou me separando dele" (p. 5-6).

A segunda filha iniciou o tratamento com anti-retrovirais, bem como seus pais. Aos cinco meses de idade, a nutricionista do Centro de Referência, onde eles eram atendidos, encaminhou-os para a Avaids. Eliana considera o atendimento na Avaids muito importante, constituindo uma oportunidade de fazer novos vínculos com outras mães, e a possibilidade de sair de seu isolamento.

"E: E por falar nisso, como é que vocè vê o acompanhamento aqui na AVAIDS?

Eli: Abriu muitas portas, muitas dúvidas eu tirei, pessoas, eu conheci muitas mães em situações iguais ou melhores que eu. Com historias diferentes, vidas diferentes, tirei muita dúvida. Não tive curso no hospital, mas teve aqui. Psicóloga, teve aqui. Então eu acho que a força que eu fiquei foi aqui que eu consegui tudo isso. Até hoje, sempre tem alguém para me ouvir. Foi uma ajuda importante..." (p. 14).

Eliana contou que a situação da terceira gravidez foi um "descuido" e que ela teve, além do medo de que seu bebê, também, nascesse com HIV, como, também, teve medo de enfrentar novas situações de preconceito. A terceira filha, que não nasceu com HIV, foi "salva".

"Eli: É que ai não foi tanto. Porque na primeira gravidez eu não fiz pré-natal. Eu tinha 16 anos e não fiz pré-natal. Já da Marisa, eu vi que era muito importante, eu fui preparada, fiz tudo certinho, planejei tudo. Al no da Hebe eu fiquei com medo, no sentido de medo mesmol Eu não sabia explicar esse medo. Só que a equipe all no caso, era mals aberta, falava muito e eles tranqüilizavam. Quando eu dizia que estava com medo, outras pessoas já nāo tinham. 0 único medo que eu não perdi foi a discriminaçāo. Da Marisa eu nāo sabia e da Hebe eu já sabia. Entāo eu falei, meu Deus, se eu chego no hospital e já vou chegar com a carteirinha que sou HIV e tudo. Então a discriminação, né? De tanto que eu fiquei com medo da discriminação, graças a Deus não aconteceu" (p. 9).

(...)

"E: (...) E da terceira filha vocé sentiu que as pessoas poderiam pensar "ah, mas ela já tinha o HIV e teve outra...". Tipo "nossa, que irresponsabilidade"?

Eli: Senti. Por que a Hebe veio assim, foi um descuido meu, eu não queria.

E: Como assim, um descuido?

Eli: Porque a camisinha, até algumas semanas atrás eu usava camisinha de uma forma que não era correta. Então foi um descuido, eu não planejei ter ela, entendeu? Para mim, eu vejo como um descuido.

(nas semanas anteriores houve um treinamento na ONG sobre o uso de preservativos masculino e feminino. A entrevistadora estava presente $\theta$ a entrevistada foi uma das participantes.).

E: Descuido? E se você não quisesse ter filhos... (silêncio prolongado). Mo parece que é essa a questão... Como é que a gente decide que vai ter um filho? Como que é esse negócio de ter um filho e levar essa gravidez à diante? 
Eli: Eu acho assim, você prepara o seu espirito para receber uma, um ser, né?

A sua vida vai mudar...

E: Que foi mais ou menos, como você fez da segunda gravidez...

Eli: É isso.

E: Você disse que pensou, será que vem um menino? Por que você achou que era um menino?

Eli: Porque eu já tinha uma menina. Se vinha um menino e... Parar ali.

E: E na terceira, você não queria um menino?

Eli: (respondeu rápido, sem pensar). Queria tambéml Assim, foi assim...Eu não, eu não...Eu fiquei grávida (gaguejou). Assim, eu passei por tudo...Não queria passar o mesmo da Marisa, não... Agora vou me cuidar direitinho... Vou fazer tudo certinho. Eu já tinha me cuidado, mas ia fazer mais coisas ainda.

(...) Como a Marisa aconteceu (contraiu o HIV), mas com a Hebe eu consegui, como se diz? Salvar, no caso..." (p. 12-13).

A situação de alimentação do bebê causou um desconforto para Eliana, quando percebeu a atitude da enfermeira, que a cobriu com ataduras, como um ato de desconfiança, como se ela temesse que Eliana amamentasse sua filha, escondido. Ela sentiu muito, por não poder amamentar, pois considera que "mãe amamenta".

"E: Você ficou preocupada com isso? Como você ia falar para as pessoas
que não estava amamentando? Eli: Sim. Eu acho que eu me isolei porque não sabia o que falar, no caso.

E: E como é que foi a experiência de não amamentar?

Eli: Eu me senti... Como é que se diz... Não sendo mãe. Porque eu acho que mãe amamenta. Eu acho isso. Traz tanto beneficio pra criança e não estar podendo amamentar, né? Eu também não estaria prejudicando ela. Então balanceou, eu senti, não podendo e ao mesmo tempo protegendo ela.

E: Mas no hospital, te enfaixaram e a enfermeira disse "norma do hospital, tem que ser assim". Tem que ser assim?

Eli: Eu acho que não. Mas ela achava que sim.

E: Ela foi rude com vocé?

Eli: Não. Mas ela falou tem que enfaixar deu uma justificativa como se achasse que eu fosse fazer isso. Mas eu não ia fazer. Mas para nāo criar caso, deixei.

E: Vocé sentiu uma certa desconfiança dela. Se ela virasse as costas, vocé ia amamentar... Vocé sentiu que ela estava to julgando?

Eli: Inclusive, todas mäes perguntavam. Como é que foi, como que foi que eu peguei. A maioria perguntou. Foi duas que não perguntou.

$E: E$ como você justificava?

Eli: Eu falava que eu peguei do meu marido e já tinha começado o tratamento $\theta$ elas perguntavam "você pegou do seu marido?". Elas não acreditavam. Era assim, ou ele era meu companheiro há muito tempo ou era um namorico. Eu não planejei... Eu me senti assim tão... Eu me isolei mais. Aí eu pensei que não tenho que ficar falando da minha vida para elas.

E: Por que você tem que dar satisfação da sua vida? Mas você percebeu que causou um certo desconforto nelas?

Eli: Eu acho que sim, elas pensariam pegou do marido? Será que era marido ou era só companheiro?" (p. 10-11)

Ela acredita que, não é pelo fato de ter HIV que uma mulher pode desejar ter filhos, pelo contrário, 0 fato de ser soropositiva acaba, relativamente, "tirando o prazer da maternidade", por trazer mais preocupações com a saúde, tanto da mãe, quanto dos filhos (caso venham a ser soropositivos, também). Entretanto, Eliana observou que, para algumas 
mulheres, a maternidade pode servir de estímulo para viver, para que a mulher se cuide melhor para poder cuidar dos filhos, ou, em suas palavras "ser mais guerreira".

"Eli: O que é ser mãe? Ser mãe é... Eu não sei especificar o que é ser mãe. $E: O$ que tem vem na cabeça?

Ell: Eu penso na minha mãe.

E: Na sua mãe? E se você tiver que traduzir isso? Que papel você acha que ela fez?

Eli: Um ótimo papel. Ela é uma mãe guerreira, uma mulher guerreira.

E: Então para ser mãe, tem que ser guerreira?

Eli: É, não é fácil... (risos). Não é moleza (risos).

E: Mas pelo jeito, tem coisas gostosas em ser mãe?

Eli: Ah, tem.

E: E ser mãe e portadora do HIV? Como é que é?

Eli: Tem que ser guerreira, né? Acho que duas vezes. Tem que ser mais...

E: Mais guerreira ainda? Duplamente? Por que?

Eli: Porque seu filho vai depender muito mais de você, em todos os sentidos. $E$ a criança ser portadora e a mãe ser, tem que ser mais ainda tem que ser muito mais forte. Mesmo que você não seja. Eu não sou forte todos os dias, mas tem que demonstrar que está tudo bem. Tem que demonstrar que as coisas são difíceis, mas que você tem que lutar, você vai conseguir chegar lá.

(...)

E: Você acha que ter o HIV influenciou de alguma forma na sua decisão de ter um filho? Por que na terceira filha já tinha o HIV...

Eli: Não. Foi um descuido, vamos assim dizer... Não entendi... Fala de novo...

E: Assim, ter o HIV influenciou de alguma maneira? Se pesou de alguma forma na decisão de ter um filho. Você poderia ter ficado grávida e não querer ter esse filho, fazer um aborto, vou dar para alguém, por exemplo.

Ell: Não...

E: Pergunto se pode o HIV pode ter tido um peso positivo justamente por ter HIV, que eu vou ter esse filho" ou um peso negativo "ou por ter HIV, é horrivel ter esse filho". Se o HIV influenciou de alguma forma na tua decisão.

Eli: Não, acho que não. Porque se eu tivesse ou não tivesse o HIV, eu teria da mesma forma.

E: Mas tendo o HIV e tendo sua filha, vocé na sua filha mais um motivo para lutar pela vida?

Eli: Sim.

E: Então de fato o HIV influenciou...

Eli: Influenciou, assim...Positivo. (...) Eu tenho que viver, eu tenho que me cuidar porque eu quero viver bem. Eu quero cuidar bem, eu quero estar bem. (...) Assim, eu tenho HIV. Eu fiquei me senti como qualquer outra pessoa que está grávida. Mas não é porque eu tenho HIV que eu vou ter um monte de filhos. Acho que a gente perde um pouquinho, corta um pouquinho, não sonha tanto como a que não tem HIV. Eu vejo assim. Por mais que eu me cuide, que tenha tratamento, eu não sei o quanto eu vou viver... "(

Eliana apresenta dificuldades em lidar, abertamente, com a questão do HIV, em algumas situações sociais, pois ela e sua filha recebem alguns benefícios, como vale-transporte gratuito. $O$ recebimento de benefícios acontece, mediante a exposição da "deficiência", e ela não quer que sua filha, ou ela mesma, sejam vistas como dignas de "pena". Trata-se de uma situação que aponta para contradições e impasses, difíceis de serem superados. 
"Eli: Ontem mesmo eu fui renovar minha carteirinha do SP-trans. A Marisa tem carteirinha e eu fui renovar. (...) E (a moça) perguntou "o que ela tem?". Eu falei assim "ela tem uma doença muito especial. Eu não vou falar, não quero falar". Foi a primeira vez que eu falei isso, mas eu achei que ainda não saí bem. Aí ela disse "mas ela não tem nada". Eu disse que ela parece que não tem, mas ela tem. Ela viu que eu pus um ponto final, ela continuou a conversa, talvez pensando que eu ia acabar falando, ela falou da filha dela e eu disse "legal". Ai acabou. Eu não tenho nada que ficar falando porque eu tenho uma raiva da pessoa sentir dó. Assim, ai ela é tão novinha, coitadinha. Isso não vai resolver. E: Não é isso que você precisa...

Eli: Não! Eu quero que ela tenha uma vida normal. Então se eu falar, já fica daquele jeitinho, com dó, ai eu me sinto mais culpada. Podem falar "ah, você não se cuidou e sua filha pegou". Então eu não vou falar mais" (p. 11).

Eliana disse que se sente culpada em relação à filha soropositiva, pois teria sido "uma gravidez planejada". Entretanto, ela também relatou que não sabia que era soropositiva e, por isso, não tinha, naquele momento, meios para evitar a situação.

"(...) Até eu me sinto culpada, assim, por ela chegar na idade que ela vai entender, como que eu vou explicar muitas coisas, assim... Você vai ter que se cuidar, você não vai poder ficar namorando qualquer um. Eu acho que é isso, eu me sinto culpada porque quando chegar a hora de falar, como é que eu vou falar com ela? Aí ela vai perguntar pra mim "porque eu tenho isso?". E aí eu não vou saber explicar. Fol por causa de mim e do seu pai, eu não vou saber explicar. As coisas na minha cabeça ainda nāo estão bem formadas" (p. 11-12).

(...)

"E: Vocé acha que a decisão sua, de ter um filho, sendo portadora do HIV. Vai mudar a tua vida pessoal?

Eli: Que nem assim, se eu me separar, não vou me relacionar tão fácil sabendo que eu sou portadora do HIV. Porque a pessoa que eu gostar, não vai ter como justificar. A minha vida pessoal vai mudar. Em relação ao serviço, eu penso isso. Eu posso entrar num lugar, falar que eu não sou, mas tem tratamento, todo més vocé está ali, mas um dia descobrir, também não sei o que pode acontecer... Então influencia, né?

E: O fato de uma mãe ser portadora do HIV influencia para ela?

Eli: Sim, também.

E: E para tuas filhas. O fato de elas terem uma mãe que é portadora do HIV?

Eli: Sim, também. Que nem assim, minha filha mais velha, a Helena, ela tem 13 anos, mas parece que tem oito anos. Ela faz de conta que eu sou normal e a vida continua a mesma coisa. Só que futuramente vai influenciar negativo para ela, e se eu ficar ruim? Um dia eu vou ficar...Daqui um mês, daqui um ano, daqui dez anos eu vou ter a chance de tomar remédio para curar. Mas se não, pode ser que no caminho da gente tenha outras pedras a a gente pode estar tropeçando em uma delas" (p. 19).

A entrevista de Eliana trouxe um ponto interessante, a ser destacado: a importância do olhar do outro/Outro. Como já foi dito, ela parece muito preocupada com a possibilidade de que o outro seja "preconceituoso", e tal preocupação parece relacionar-se com o fato de que ela supõe que "uma pessoa pode ter um comportamento (sexual) incorreto" e que isso vai propiciar a infecção pelo HIV. Ela parece temer que o outro a julgue como "promíscua", 
pois ela faz uma distinção entre "ser infectada pelo marido" e ser infectada por um "companheiro", ou "namorado". O medo do preconceito, nesse sentido, aponta para uma perspectiva moralista, ou seja, que há pessoas que "procuram o HIV" e há pessoas que são "vitimas do HIV". Parece que Eliana faz questão de posicionar-se com vítima, sem, contudo, levar em conta que essa perspectiva maniqueísta não contribui, em nada, para revelar o que realmente está em questão.

A posição que Eliana ocupa, perante seu desejo, é evidenciada quando ela diferencia as três gestações: na primeira gravidez, ela era "muito nova"; a segunda foi "planejada" e ela queria um menino e, finalmente, a terceira gravidez foi um "descuido". Eliana refere que se sente culpada, em relação à segunda filha, a gravidez planejada, talvez, porque foi, justamente nessa gravidez, que ela gerou um bebê soropositivo. A terceira gravidez foi "um descuido" e não parece despertar culpa, na medida em que a terceira filha foi "salva". A culpa relaciona-se, diretamente, com o fato de que sua filha tem 0 HIV, e não, pelo fato de que ela decidiu ter um filho.

Talvez o HIV constitua um legado maldito, ou uma herança, que ela deixou para a filha, evidenciando uma questão que, até o momento, ela mesma não consegue elaborar. Nesse sentido, quando ela diz que tentou "juntar as peças do quebra-cabeças" e que "as coisas na minha cabeça ainda não estão bem formadas", podemos pensar que Eliana vive um impasse doloroso: a forma como ela construiu sua história, o sentido dado, não permite que ela resolva o enigma, pois faltam peças. O significante "des-cuido" pode ser tomado como evidência da "falta de cuidado", o que nos aponta para um sentido possivel. Mas, o que esse significante deixa entrever, é um "mais além", ou seja, que, embora, conscientemente, ela saiba que não foi sua culpa, sob o ponto de vista do inconsciente, a lei é outra: o sujeito tem que se responsabilizar por aquilo que ele não pode escolher, ou seja, que é submetido à castração e, por isso, interditado ao gozo absoluto. Para Eliana, talvez, seja impossivel "completar" o "quebra-cabeças", que se tornou sua vida. 


\subsubsection{2 - Cátia: que tem medos "sem sentido"}

Síntese: Cátia tem 33 anos, é dona de casa e tem cinco filhos (uma menina de 12 anos (HIV-), um menino de 7 anos (HIV-), um menino de 6 anos (HIV+) e um casal de gêmeos de 5 meses (HIV-)). Ela descobriu o HIV, quando seu terceiro filho adoeceu, aos 3 meses de vida, e foi diagosticado com HIV. O seu companheiro não é soropositivo, e eles supõem que ela tenha sido infectada em uma transfusão sanguínea, durante a segunda gravidez. A última gravidez não foi planejada e há discrepâncias no relato da mesma. A relação com o atual companheiro é marcada por conflitos e violência.

Figura 19 - Diagrama da linha narrativa relativa à entrevistada Cátia

\section{Gestação/ bebê}

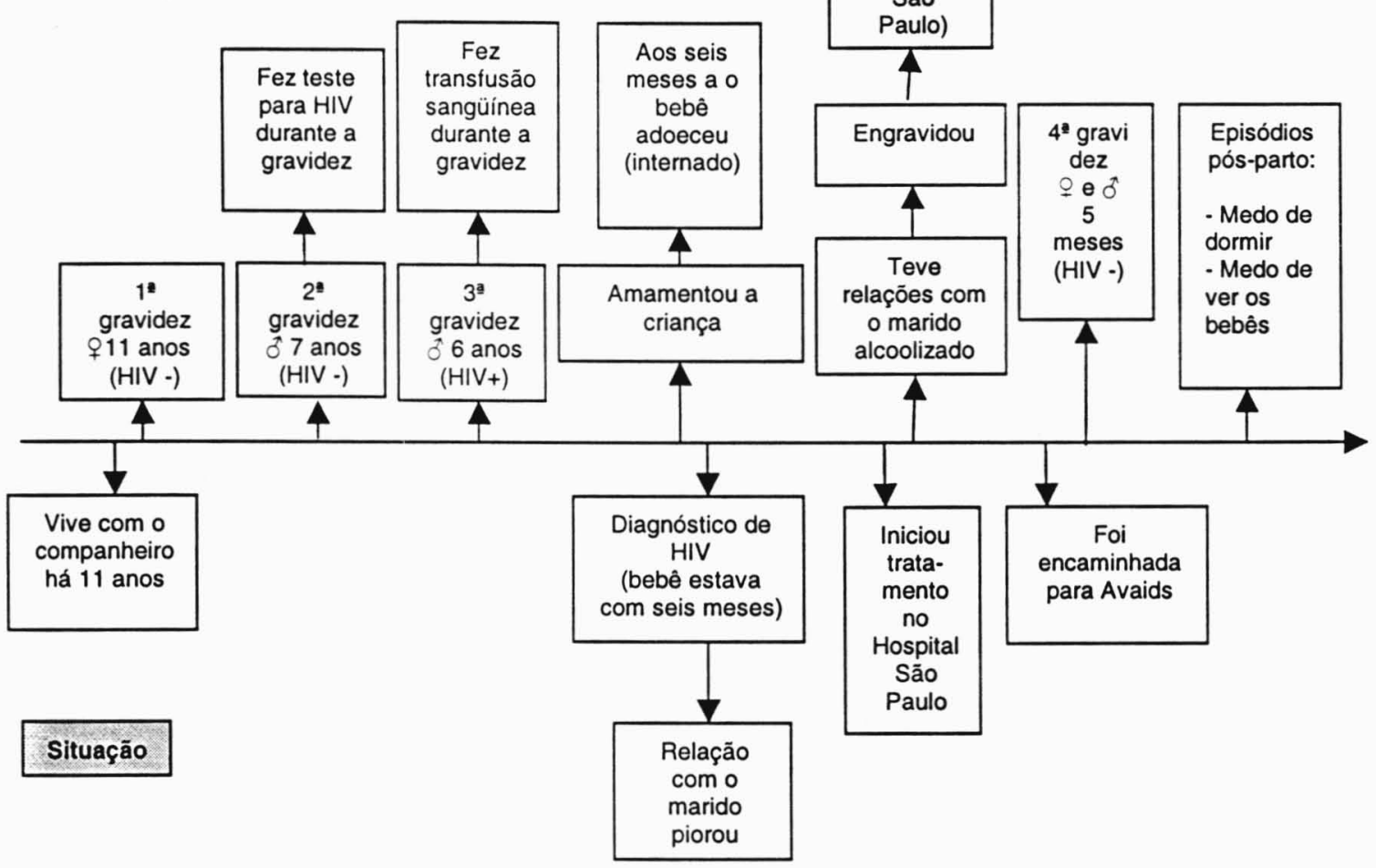

Cátia teve quatro gravidezes: cada uma delas constituiu uma experiência absolutamente diferente. Na primeira, não houve qualquer intercorrência significativa; na segunda, ela teve grave episódio de anemia e foi testada para várias doenças infecciosas (nada foi constatado); na terceira gravidez precisou de uma transfusão sangüínea, em função de uma anemia importante. Quando seu filho tinha seis meses, adoeceu (num quadro de diarréias constantes) e foi internado. 
"C: (...) "Mãe, porque você não me contou?". Contou o que? Você e seu filho estão contaminados. Nossa eu entrei em choque, falei, contaminada com o que? Você e ele têm! Ela falou assim! Sabe, assim? Não foi de chegar e falar vocé tem isso, não tinha uma estrutura primeiro, né? Dal, isso eu vou falar, ela era uma cavala, um monstro comigo.

E: Então foi a pediatra que te comunicou?

C: Fol a pediatra. Ela foi um monstro.

E: Vocé acha que ela sabia que você não sabia?

C: Mas eu acho assim, mesmo que eu soubesse, ela jamais poderia chegar e falar do jeito como ela chegou.

E: Você acha que ela nem pensou nisso?

C: Só chegou e falou." impacto:

Quando soube que seu filho tinha o HIV, sua reação foi de grande

“C: Foi horrivel. Foi desesperador. Porque eu falava de quem que eu peguei, foi... eu já imaginei que o outro (filho) também estava, foi um absurdo. Eu entrei em choque. Meu filhinho estava muito mal e é uma coisa muito dolorida para lembrar, quero pensar mais em agora. Que eu so pensava assim que meu filho vai morrer, assim que ele morrer eu vou morrer também. Eu vou me jogar debaixo de um carro. Assim que ele não respirar mais, ele estava ligado nos aparelhos, tudo, né? Eu me jogo debaixo de um carro, minha vida acabou. Eu estava vivendo ali por ele, sabe? No momento. Eu não ligava mais para os dois mais velhos. Os dois mais velhos não existiam mais pra mim. Porque eu talava que eles não precisam de mim, esse ai precisa, mas quando ele se ir, eu vou com ele, entendeu?

E: O que você achava? O que você sabia?

C: Que não tinha mais sentido! Porque eu ouvia, passava na televisão, e eu assim falava: "nossa eu contaminei meu próprio filhol", eu ficava em paranóia, sabe?".

Após esta notícia, o casal enfrentou um grande problema, pois seu marido é soronegativo e começaram a se questionar sobre qual seria a "causa" da infecção. Chegaram à conclusão que a infecção se deu em função da transfusão de sangue, recebida durante a terceira gravidez, aliada ao fato de que Cátia amamentara seu filho, durante seis meses (o peito havia sangrado). Sua relação com o companheiro modificou-se, completamente: ele a "abandonou", e depois voltou, mas tinha medo de se infectar.

"(...) Dal logo, veio o abandono do meu esposo. Meu esposo vai embora porque eu tinha e ele não tinha. Então viver o abandono do meu esposo, nós passava fome, não tinha o que comer para os meus filhos foi uma agonia muito angustiante". (...)É bem difícil, é difícil, mas ao mesmo tempo, eu nāo paro para pensar."

A quarta gravidez é uma história, "um acidente", em duas versões. $\mathrm{Na}$ primeira entrevista, ela contou que o marido, alcoolizado, depois de quatro anos sem nenhum contato sexual, procurou-a e ela pediu que ele usasse preservativo, o qual estourou. Na segunda entrevista, ela contou, sussurrando, que, na verdade, não havia usado preservativo e que seu marido tinha "feito em cima de dela". O marido pediu que ela abortasse, e ela se recusou, terminantemente. 
Na primeira entrevista:

“C: Então, ele passou quatro anos, ele lá no cantinho dele e eu cá, entendeu? Daí de tanto as pessoas falavam que eu era egoista, que eu não dava...Porque todo mundo se vem conversar com você, eu sou a ruim, ele é o certinho, mas não sabe o que acontece dentro de casa. E nos quatro anos o que aconteceu? Ele tava bêbado. Ele veio me procurar bébado, bêbado, bébado. E o que acontece. Dal tinha a camisinha e eu falei "você vai usar". Depois de quatro anos, do jeito que a gente estava, a camisinha estoura. E dai o que acontece? Passou uma semana, a minha menstruação é tal dia, bem certinho todo mês chega a menstruação e chegou aquele dia e nada da menstruação chegar. Nada. Ai eu falei, estou grávida e o medo de contar para ele e ele falar que não era dele?(...)

E ai o que aconteceu? Um acidente. Eu engravidei. Não vou tirar meu filho. Ah, então eu vou embora. Eu falei, então você vai embora. (...)Dal eu cheguei e falei para ele que eu vou fazer o ultra-som e ele disse "já resolveu de tirar o bebê?". Eu falei não. Ele falou, eu vou pedir demissão na firma e vou embora. Falei, pode pedir. Fui para o hospital, quando cheguei no hospital a médica falou, mãezinha você está grávida de gêmeosl Menina, me deu um trecol Eu falei pronto, agora que o homem vai embora de vezl"

\begin{abstract}
$\mathrm{Na}$ segunda entrevista:
“(...)Eu estava preocupada assim, como eu ia explicar para o meu marido que ou estava grávida? Já estava quase de três meses o ainda não tinha falado nada para ele. Como que eu ia explicar para o meu esposo que eu estava grávida e a pessoa muito ignorante...Ele é uma pessoa estudada e ignorante ao mesmo tempo, entendeu? Eu falava pra ele, lembra daquele dia, já faz mais de trés meses, que a gente tinha feito? A menstruação já tinha dois meses que não vinha. Ele falou como que eu vou acreditar? Lembra naquele dia que vocé estava bêbado e a camisinha estourou? Não foi bem assim. Eu vou explicar como é que foi. (começou a falar sussurrando). A gente não usava camisinha. Sabe como é que foi? Ele fez em cima de mim, aqui assim (ela mostrou as permas)(...) Eu falei, pronto! Como é que eu vou explicar para uma pessoa ignorante? Eu fui conversar com os médicos, para os médicos me explicar, que eu poderia, porque nessa parte eu também estava sendo ignorante porque eu não sabia que podia acontecer gravidez desse jeito. Eu fui no médico, lá eles me acolheram e falaram "mãezinha, é possivel sim".
\end{abstract}

Sua relação com a equipe, que a acompanha no Hospital São Paulo, é "muito boa". No pós-parto, Cátia relatou alguns episódios que lhe causaram intensa angústia. Ela teve medo de dormir, o que ela mesma interpretou como sendo medo de morrer. Teve, também, medo de ver os bebês e relacionou esse sentimento com o medo de ver os filhos, se "apegar" e, posteriormente, alguém tentar tirar os filhos dela.

“C: (...)Então foi um parto tranqüilo,né? Eu só tive um pouco de medo da cesárea. Mas passou.

E: Porque medo da cesárea?

C: Não sei, eu senti um medo imenso de não acordar.

E: Os outros bebês, vocé tinha tido como?

C: Parto normal.

E: Ah, foi a primeira cesárea.

C: Eu falava, ai meu Deus, não me deixa dormir que eu não quero dormir.

E: Vocé ficou com medo do dormir, da anestesia?

C: De não acordar, eu falava, não deixa eu dormir que se eu dormir eu não vou acordar. Sabe aquela coisa intensa assim?

E: Mas como é que é dormir enão acordar? 
C: É... assim, morrer, né? Não me deixa dormir porque se eu dormir eu não vou voltar. Aquele sem sentido."

(...)

“C: E eu não queria ver eles (os bebês)!

E. Por que?

C: Eu não queria! Porque eu estava assim, ai meu Deus, eu não quero ver eles. Se eu ver eles, depois vão tirar de mim. Eu ficava assim, sabe? Eu não quero ver eles. Vou ver uma coisa que vão tirar de mim? Eu ficava assim, sabe? Daí eu fiquei, na hora assim e não falava para ninguém, só comigo mesmo. E nervoso, menina. Eu sem roupa, os bebês estavam sem roupa, com a sacola toda arrumada, semanas. Mas meu marido não aparecia para levar roupa $\theta$ eu fui e não levei porque sai correndo, né? Então os bebês $\theta$ sem roupa pra mim, então estava angustiante, sabe? Eu nāo queria ver eles. Eu falava vou dar um tempo,sabe? Era para mim ver de manhã e eu só fui ver a meia noite, que eu fui ver no berçário mesmo.

E: Por que você acha que tinha essa questão de tirar os bebês?

C: Eu não sei. É que nem o negócio de não dormir. Eu não queria ver eles, eu falava nāo quero ver agora.

E: Você sentiu isso nas outras gravidezes?

C: Não, não. (...) Dai eu olhei para ele, depois que ele chegou, nossa, tão petiquinho, assim. Eu senti que eles estavam precisando tanto de mim ali. Eu falei, nossa!(...) Eu fui me aproximando deles, foram para o quarto, dai fui dar o primeiro banho, né? Eu dei o banhinho dál eles ficaram mais bonitinhos, né? $E$ foi indo, eu já comecei a cuidar deles."

O processo de alimentação das crianças, no pós-parto, também parece ter gerado conflitos: por que Cátia tinha em "excesso algo inúti", enquanto "faltava em outras algo útil?" De que "excesso" e de que "falta" realmente se trata?

"E: Dal, foi. E como foi a amamentação. Você não...

$C: E$, já tinham me orientado, me enfaixado, dado medicação durante o mês, para o leite secar e por incrivel que pareça eu juntei mais leite desse do que dos outros. Daí fui para o quarto, não era quarto separado. Eles não isolam vocé de ninguém, dai quando dá remédio, a enfermeira fala assim, tomou seu remedinho? Dai as meninas ficaram assim do lado, porque vocé está enfaixada? Por que você não pode dar mamar? Igual, as enfermeiras vinham trazer a mamadeira e elas falavam "ela tem anemia". Ela tem uma anemia muito forte e se der mamar o nené pode fazer mal para o nenezinho. Então não pode tomar, entendeu?

E: Mas como você sentiu essas perguntas?

C: Ah, normal. Tinha hora que me dava vontade de pegar e falar porque tinha umas coisas... Eu chorava assim, menina, meus peitos cheios de leite $\theta$ eu não podia dar mamar, entendeu? Via outras lá dando mamar, uma mulher desesperada do lado, não tinha um pingo de leite e o meu estava tão cheio, tinha tomado tanto remédio e estava toda enfaixada, ai... uma agonia.

E: Muita agonia, angustiante.

C: Entāo não dá... sabe? Eu falava meu Deus, porque eu não posso dar mamar para os meus filhos? Por que não? Não está certo! O meu leite, por que esse leite que veio pra mim não está na mãezinha do lado, né?"

A maternidade configura-se, para Cátia, como uma dádiva, que a diferencia de outras mulheres, "desprovidas" dessa possibilidade. Mas a questão do HIV aparece como uma angústia "de fundo", sempre presente, o que faz com que ela se questione sobre um "risco iminente" de morte, tanto para ela, quanto para o filho. Embora a angústia e o medo se façam presentes, 
ela procura viver e dar amor para os filhos, enquanto Ihe for permitido, ou seja, "até que o pai do céu venha the chamar".

Ser mãe e soropositiva implica uma série de conflitos, pois há um medo constante de que ela possa vir a adoecer e deixar seus filhos pequenos. No caso de seu filho soropositivo, haveria, também, o risco de ele ficar doente e sem ter quem queira lhe prestar cuidados. Por outro lado, Cátia ressalta que a maternidade pode ser um estímulo para a vida e aponta que, embora no seu caso isso não se aplique (porque sua última gravidez foi um "acidente"), ela observou que algumas mulheres podem ver, no filho, uma verdadeira força para a vida e, assim, desejarem ter filhos, após a infecção pelo HIV.

\section{"E: E como é ser mãe e ser portadora do HIV?}

C: $\dot{E}$ difícil. $\dot{E}$ difícil porque no meu momento eu fico pensando assim, lógico que você poderia ter outra doença, vocé poderia também ir logo, no caso. Eu fico pensando assim porque eu tenho as minhas duvidas da escola, dos amigos dos meus filhinhos da escola, porque agora todo mundo vai pra escola, ne? Falar assim, descobrir um dia: Ah, tua mãe é... sabe começar a... isso. E o resto é angustiante um pouco porque eu tenho medo de deixar os meus filhos pequenos sem poder se virar sozinhos, só isso."

(...) "E: E como é ser mãe e ser portadora do HIV ao mesmo tempo?

C: É o que eu te falei agora a pouco, é difícil. Porque você está ali e não sabo o momento que pode acontecer alguma coisa, você está ali. Eu falo, meu Deus me dá forças. Eu tenho dois filhos pequenininhos me dá força para eu pelo menos deixar grandes. Então eu estou no ônibus e eu estou pensando nisso, eu falo assim, eu só peço isso, para Deus me dar forças. Já que o senhor me deu esses dois. Eu já tinha só o $\mathrm{B}$. e mais os três e eu já estava pensando de deixar eles mais adultos, no caso. $E$ agora o senhor me deu mais dois, eu vou ter que me cuidar mais. Nāo vai deixar eles sozinhos!

E: Então deixa eu ver se eu entendi. Então esses dois acabam sendo até um estímulo pra você querer viver?

C: Realmente, demais. Eu falei, se você me deu eles, não é para me tirar agoral Na hora que eles precisar de miml Eu paro para pensar e falo, Deus me deu um desses para mim ter mais vontade de viver e viver por eles. Porque eu vivo por eles".

O relato de Cátia evidenciou que o momento da noticia, a respeito dos exames de acompanhamento dos bebês, de que são soronegativos, the causou um "alívio".

O HIV pode influenciar outras mulheres na decisão de ter um filho, mas ela não admite isso para si mesma. Interessante notar que ela havia dito que teria muitos filhos, mas que, agora, não quer mais.

"Eu fui mãe cinco vezes e se Deus quiser, eu tinha alguns sonhos. Eu acho que se eu tivesse uma saúde boa eu teria mais uns cinco. É muito bom, cada gravidez foi uma gravidez diferente, cada uma...mas é um amor imenso. Nossa quando eles estão ali dentro, quando eles nascem, é muito bom."

(...)

"E: $E$ a gente estava falando da questão de ter um filho, como que foi para vocé ter esses filhos, foi a partir daquela relação que você teve, foi uma coisa meio que inesperada, mas que você quando soube que estava grávida levou adiante sua decisão, não é? Então só pra marcar bem essa questão, o fato de uma pessoa ter o HIV, você acha que isso pode ter uma influência dela querer ter filhos, dela desejar ter filhos para poder lidar com o HIV? 
C: Porque às vezes eu acho que sim. Vamos supor uma mulher que ás vezes não tem filhos $\theta$ eu conheço um bocado de mulheres que querem ter um filho só e não querem ter outros filhos e não operou, entendeu? Então elas querem ser mães mais duas vezes, mais três vezes.

E: Vocé acha que pelo fato de ter o HIV, pode dar mais vontade de ter filhos?

C: Mais vontade de viver, de cuidar do seu filho, entendeu? Então é muito da mãe".

A relação com o filho soropositivo é marcada pelo medo de que ele venha a adoecer. Ela não vê, nos tratamentos, uma garantia de vida, mas uma possibilidade de sobrevida.

"Então eu vejo ele cada dia, eu vejo ele assim, ele fala, conversa comigo, ele vem, ele me explica as coisas, ele vai pra escola, eu só vejo parabéns, entendeu? Então eu vejo, eu sei que mais tarde eu posso perder ele, mas eu nāo penso nesse momento, entendeu? Eu só penso nos momentos que ele está me dando, entendeu? Então é ruim, mas eu não penso. Eu só vivo, entendeu? Eu só vivo aqueles momentos, eu não penso na doença, eu não penso nisso, sabe? Então eu só vivo aquele momento".

A função de um filho, depois de todo seu percurso, com relação à maternidade, é a de ser uma "bênção", ou seja, aquilo que santifica um lar. Nesse sentido, a sua quarta gravidez, embora inesperada, mostrou-se uma bênção, além de tudo, incomum, pois "Deus havia mandado gêmeos".

"C: Pra mim eu acho que foi uma bênção de Deus, eu acho que eu estava precisando, né? $E$ eu acho que Deus fez a coisa certa pra mim. Agora pra ele ou não sei porque ele (o marido) nunca me fala nada, entendeu? Pra mim eu sei que foi uma bênção de Deus, porque Deus me deu, no lugar de uma sementinha, me deu duas. Nāo foi, vamos dizer assim feito com amor, mas eles vieram com amor para mim, entendeu? Foi uma coisa muito boa que aconteceu".

(...)

"C: Ter um filho, eu acho que é uma oportunidade de dar muito amor pro teu filho. Precisamente no meu caso, ensinar ele o pouco de vida que resta, né? Passar para ele um pouco de segurança porque se vocé faltar, já vai deixar o seu filho preparado, dar muito amor, ensinar coisas boas. Isso eu tenho que fazer para os meus, né? Eu falo para eles que eu não vou estar toda vida pertinho deles e que talvez vai ser... venha rápido. Talvez vai demorar muito tempo para o pai do céu me chamar".

$\mathrm{Na}$ última gravidez, Cátia foi acompanhada na Avaids. Ela ressaltou a importância do trabalho dessa instituição, à qual, inicialmente, havia procurado para receber leite, e acabou encontrando apoio, amizade e um alivio para sua solidão.

“C: (...)Me sinto muito bem vinda, o pessoal todo é legal e eu estou gostando. Eu estou também bem melhor depois que eu estou aqui, né?

E: Você está fazendo acompanhamento só no grupo?

C: Eu já estava fazendo antes e agora eu estou fazendo com o grupo também. Então eu estou me sentindo bem melhor porque eu estava bem, sei lá. Eu estava me sentindo só, agora não estou mais, entendeu?"

C: Pra quem está podendo escutar as coisas, tudo bem. Mas quem não está, você pode explicar mil vezes que não adianta nada". 
Cátia mostrou-se uma pessoa muito acessivel que, ao apontar uma série de angústias e medos, permitiu a explicitação de alguns sintomas. O medo de dormir e o medo de ver os filhos parecem ser construções que indicam que há, naquele momento, uma angústia imensa e não declarada, mas que, afinal, impõe efeitos na sua relação com o outro. Sob o prisma da psicanálise, a fala "aquele sem sentido" é notável, pois tem o mérito de não se "encaixar", totalmente, na estrutura semântica da frase e apontar que, justamente, ali, naquele ponto de seu discurso, há algo para além do sentido, o que, afinal, é o foco de interesse da investigação do inconsciente. $O$ fato de que a frase diga, em si, sobre a falta de sentido ("aquele sem sentido") faz com que possamos apontar, com mais clareza, esse aspecto.

Perante a situação do parto, da iminência do corte preciso em seu corpo (cesárea), da separação entre ela e sua produção (bebês), temos a formação de um significante, que nos leva a pensar que há um sujeito deparando-se com sua falta e com a angústia ali imbricada. Se tomarmos seu discurso, sob o ponto de vista da "produção de sentido", é evidente que podemos avaliar seus medos como "normais", considerando-se a situação. Entretanto, ela mesma apontou que havia um estranhamento, em relação ao que ela havia sentido nas gravidezes anteriores. $\mathrm{Na}$ sua última gravidez, havia algo diferente: seria 0 HIV? Ou, o HIV re-edita uma questão anterior? A psicanálise trabalha com a estrutura lingüistica, que aponta para o surgimento do sujeito do inconsciente, algo da ordem do "sem sentido".

Outro ponto interessante, diz respeito à situação de alimentação do bebê no pós-parto, pois ilustra uma questão importante: de que excesso se fala? E o que realmente falta? O leite materno, enquanto signo de doação e completude da diade mãe-bebê, tornou-se, para a soropositiva, um signo de sua falta, caracterizada pelo HIV. Para Cátia, sua falta causa excesso, ou seja, ela tem em excesso o leite que não pode dar aos filhos. Esse leite, não apenas podia infectá-los, como também, ela tinha a convicção de que isso, efetivamente, já havia acontecido com seu filho anterior. $O$ que ocorre é a manutenção da questão, que ficou pendente e, com esse fato, não resta ao sujeito outra alternativa, a não ser, fazer um sintoma. No caso de Cátia, o sintoma é uma demanda a um Outro onipotente: "Eu falava meu Deus, porque eu não posso dar mamar para os meus filhos? Por que não? Não está certo! O meu leite, por que esse leite que veio pra mim não está na mãezinha do lado, né?"

A notícia de que seu filho era soropositivo the causou culpa e, embora, conscientemente saiba que não foi sua culpa, sob o ponto de vista do inconsciente, a lei é outra: o sujeito tem que se responsabilizar por aquilo que ele não pode escolher, ou seja, que é submetido à castração e, por isso, interditado ao gozo absoluto.

A mudança de sua versão, da quarta gravidez, gera uma questão: o "acidente" foi com o uso de preservativo, ou não? O que nos interessa, nesse momento, é perguntar sobre o motivo que a leva ter que "criar" tais versões. 0 que estaria em jogo? Quanto a isso, só podemos levantar hipóteses, mas não 
parece ilógico lembrar que "a verdade" é sempre uma "versão da verdade", pois, tanto a psicanálise, quanto a filosofia, foram veementes em apontar que não há "A Verdade" (LACAN 1992). Cátia conta a segunda versão "sussurrando", o que nos faz pensar que alguém não pode ouvir essa nova versão. Que outro ou Outro não pode escutar? Não vamos deixar de considerar que, atualmente, as mulheres que participam de grupos de apoio são orientadas a comportarem-se corretamente, usando preservativo em todas as relaçōes, inclusive, estando grávidas, com intuito de evitar o risco de infecção cruzada. Se, antes, eram criticadas por "terem sido moças que não se comportaram", agora parece que são criticadas, por não obedecerem aos preceitos da equipe de saúde.

O discurso de Cátia, também, permite-nos vislumbrar sua posição em relação ao desejo: o filho foi um "acidente causado pelo ato do outro que fez (gozou) em cima dela". Ela nada tem a ver com isso. Trata-se da posição histérica, em que o sujeito é uma "vítima" do desejo do Outro, submetendo-se, mas não sem conseqüências: ela tem que "brigar pela vida dos filhos", porque seu companheiro queria obrigá-la a fazer um aborto.

A quarta gravidez, na assunção de poder dar à luz, acima de tudo, gêmeos, parece constituir algo que a completa, ou, em suas palavras "Pra mim eu acho que foi uma bênção de Deus, eu acho que eu estava precisando, né? $E$ eu acho que Deus fez a coisa certa pra mim."(...) "Pra mim eu sei que foi uma bênção de Deus, porque Deus me deu, no lugar de uma sementinha, me deu duas. Não foi, vamos dizer assim feito com amor, mas eles vieram com amor para mim, entendeu? Foi uma coisa muito boa que aconteceu".

Parece que, se o filho é o que ela precisava (o que faltava) e a completa, o HIV é algo que "des-completa". Ter gêmeos constituiu uma oportunidade de superação do diagnóstico de HIV e, pelo fato de já ter dado à luz um filho soropositivo: "Ter um filho, eu acho que é uma oportunidade de dar muito amor pro teu filho. Precisamente no meu caso, ensinar ele o pouco de vida que resta, né? Passar para ele um pouco de segurança porque se você faltar, já vai deixar o seu filho preparado, dar muito amor, ensinar coisas boas". Parece que a oportunidade está, justamente, no fato de que seus filhos constituem uma superação da pobreza, da fome, do abandono do marido e, finalmente, da doença (HIV). 
6.1.13 - Celina: o marido foi condenado (preso) e ela sofreu uma condenação (o HIV)

Síntese: Aos 28 anos, tem dois filhos: o primeiro filho tem 11 anos (seu pai faleceu assassinado, quando ele tinha 6 meses de vida) e o segundo filho tem 7 meses (o pai é angolano). O diagnóstico de HIV ocorreu, durante a gravidez do segundo filho, quando seu companheiro estava preso e ela se encontrava no $3^{\circ}$ mês de gestação. Ele foi libertado, quando ela estava no final da gravidez. Há um pacto de silêncio entre o casal, e o companheiro (soropositivo+ Hepatite C) não se trata. Eles fazem uso esporádico de preservativo masculino.

Figura 20 - Diagrama da linha narrativa relativa à entrevistada Celina

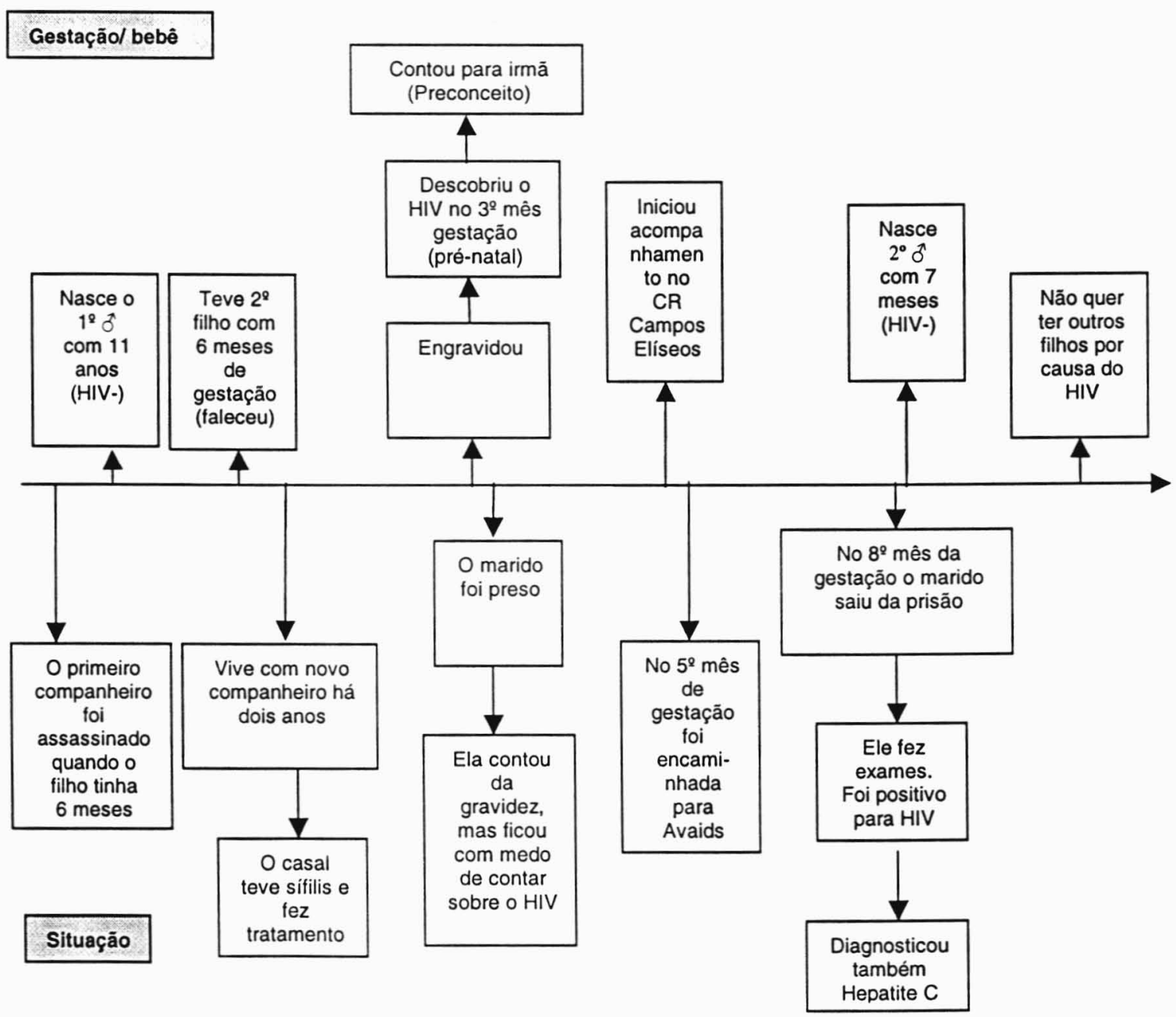


Celina descobriu que tinha o HIV em um momento bastante difícil de sua vida: seu companheiro tinha acabado de ser preso e ela estava grávida. No terceiro mês da gestação, foi fazer o pré-natal e recebeu a notícia, de que seu teste para HIV tinha dado positivo.

Seu primeiro companheiro foi assassinado, quando seu filho tinha apenas seis meses de vida (hoje seu filho está com 11 anos). Ela teve um segundo filho, que nasceu no sexto mês da gestação e, em virtude da prematuridade, acabou falecendo.

Há dois anos, iniciou seu relacionamento com o atual companheiro, que é refugiado da guerra de Angola. Ela sabia que, antes de iniciar esse relacionamento, não tinha o vírus, pois havia doado sangue e feito exames. Chegou, então, a pensar que o companheiro sabia que tinha o HIV e não havia Ihe contado. Algum tempo antes disso, o casal havia feito um tratamento para sífilis.
"(...) Então achava que era meu companheiro e ficou a dúvida se ele sabia que tinha e me passou. E o medo de ter passado pro meu filho. $O$ medo. Ele ficou muito tempo na prisão e eu tive que segurar tudo sozinha. 0 medo de dizer a ele que eu sou soropositiva e ele não ser. O medo de dizer a ele e ele naquele lugar, naquela circunstância e ele tentar alguma coisa pior, por exemplo, se matar. Por estar preso e a mulher dele estar grávida e pelo fato de ser soropositiva e ele também ser e ele tirar a vida, entendeu? Então juntou tudo e eu precisei passar muito com o Psicólogo. E outra, eu não podia falar com meu filho o que eu estava passando. Não podia contar com ninguém. Foi muito difícil. (...)" (p. 2-3).
(...)
"C: Eu falei vou ficar sem marido de novo, mais uma criança, mais responsabilidade e o HIV, que até então eu não sabia que poderia conviver com ele (o HIV), assim, normalmente. Eu pensava que ia começar a cair aos pedaços, que ia morrer no dia seguinte. Eu pensei, é o fim mesmol" (p. 9).

Ao contar para sua irmã sobre o HIV, surpreendeu-se com sua reação, pois ela não lhe deu apoio, pelo contrário, sugeriu que ela fizesse um aborto. A descoberta da gravidez e, mais especificamente, a descoberta do HIV, foram interpretadas como uma condenação ou punição.

"C: E a minha irmã não queria que eu levasse à frente.

E: Ela achava que você não deveria levar a gravidez à diante?

C: Não deveria. Então, assim. A condenacāo por estar grávida, a condenação por ter HIV.

E: Vocé se sentiu condenada?

C: Ah, eu me senti condenada! Porque ou já tinha um filho de 10 anos que o pai foi assassinado, o marido preso. Tinha uma gravidez $\theta$ tinha uma doença que não tem cura. (...) Porque isso é tipo, uma punição. Mesmo se vocé está boa, vocé ainda pensa isso, entendeu?

E: Mas vocé não acha que é uma punição... se for uma punição, uma coisa, meio... Meio... Demais?

C: Uma puniçäo?

E: $\dot{E}$.

C: Porque assim, uma punição é uma coisa forte. Se você não faz de maneira correta que tem que se fazer, então você é castigado por isso" (p. 3). 
Quando contou para sua irmã sobre o HIV, Celina percebeu que havia uma rivalidade entre as duas: sua irmã era "namoradeira" e não foi "punida com o HIV" e Celina, que tinha um "relacionamento seguro", foi "punida".

“C: E bom você se precaver. Ela foi fazer o exame também, mas para ela foi assim, tipo, uma glória. "Não, ela estar e eu não to". Me senti pior ainda.

E: Vocés já tinham uma relaçāo de rivalidade?

C: É. Ela tinha uma certa rivalidade comigo. Como eu sou a mais velha, eu sou muito rígida em algumas coisas. É o tipo da coisa. Quando eu soube do HIV, eu me admirei. Por que? Por que eu? Porque para mim isso era coisa de pessoa promiscua. Por que eu, se eu tinha um relacionamento seguro. Eu não vivia trocando de parceiro. Por que eu? Eu não me permitia isso. Como ela era muito namoradeira, por que não ela? Por que não ela? Isso só acontece com outras pessoas. Comigo, nāol" (p. 6)

Celina recebeu a notícia do HIV no posto de saúde, dada por uma enfermeira que, segundo ela, a assustou. A notícia teve um grande impacto e Celina pensou que ela iria morrer, antes mesmo de dar à luz. "Ah, pensei que meu filho também ia nascer (com HIV). Que eu ia morrer logo. Podia até morrer antes do nené nascer'(p. 8).

No Centro de referência, Celina recebeu outro tipo de acolhimento, sendo informada sobre a possibilidade de seu filho nascer sem o vírus. Ela se sentiu preparada para enfrentar a doença e o tratamento, deixando de aceitar o rótulo de "aidética", que sua irmã lhe havia impingido.
"C: Me acolheram bem (no CR Campos Eliseos). A assistente social me acolheu bem, falaram que não é assim. Você não está doente. Se tiver alguma doencinha a gente vai tratar. Vamos fazer mais exames para ver se é... Porque quando se está grávida as defesas mudam. Essas coisas mais consolam, mas também não resolveu.
E: Vocé tem uma perspectiva, olha pode ser que dé tudo certo. E al quando você se viu orientada, com as informaçöes...
C: Bem mais segura. Não, não tó doente, não vou morrer. Vou cuidar dos meus filhos. Me senti preparada para enfrentar o tratamento.Não como aidética.
E: Não como aidética?
C: Não como aidética porque o que passa é que você já é aidética. Eu tô com Aids.
E: Foi essa a sensação que você teve quando recebeu a notícia.
C: Era assim que a minha irmã me chamava. Ficava aquilo."(p. 5-6).

A reação do companheiro, diante da notícia da gravidez, foi positiva, mas Celina decidiu não contar sobre o HIV, enquanto ele estivesse preso, pois temia que ele tentasse se matar e, assim, seu segundo filho também ficaria órfão de pai. Ela "inventou" uma doença, para justificar o uso de preservativos nas visitas íntimas, enquanto ele estava preso.

"C: (...) Da gravidez? Nossa, ele falou pra mim. Elo adora criança. Ele tem um outro filho de quatro anos. Ele não é nigeriano. Ele é angolano. Mas no primeiro momento ele ficou muito feliz. Nossa, ele adora os filhos. O problema da gravidez... Problema nãol A vinda da gravidez foi ótimo. E ele soube na prisão. O fato de ele estar preso não foi o melhor momento. Não! Ele aceitou bem, mas fiquei sozinha o tempo todo, assim. Al a gente teve que usar camisinha na gravidez, para não passar. Eu tive que falar para ele que eu tive 
um problema, que eu estava sendo tratada. Que tinha que usar camisinha para não passar para o nenê. Eu tinha que estar mentindo sempre. Sempre. Eu tinha que estar mentindo sempre.

E: Você tinha medo do que?

C: Eu tinha medo de, por exemplo, de passar pro nenê. De não usar camisinha e passar pro nené.

E: De passar pro nenê, por não transar com camisinha?

C: É. Na gravidez. Porque pode passar. E tinha medo de falar para ele e tentar uma coisa pior. E desse aqui ficar sem pai também. Então eu passei por esse trauma, e fui confiando. Mas foi dificil passar" (p. 4).

Parece existir um pacto de silêncio, entre o casal. $O$ companheiro não se trata e não conversa sobre seus problemas, muito menos sobre o HIV. Ele não gosta de usar preservativo e eles têm relações sexuais desprotegidas. Por outro lado, ela admitiu que, em alguns momentos, ela coopera ativamente com essa decisão do companheiro, pois ela não consegue, ou não quer, usar o preservativo. Celina acredita que o "risco de ter um filho, com HIV" é muito grande, e decidiu não ter mais filhos. Em função disso, toma anticoncepcional oral.

"C: O problema é que ás vezes ele não aceita o preservativo. Então acaba passando mais virus, mais possibilidades de mutações.

$E$ : $E$ cadê a mulher bem comportada?

$C:$ É que às vezes o comportamento nosso não depende só de nós.

E: E depende de que?

C: Da outra pessoa. Porque ás vezes você acaba cedendo porque você quer estar bem, você quer que o relacionamento esteja bem, pra vocé. Por exemplo, eu gosto muito de conversar, discutir. Ah, mas não está certo, não está certol $O$ que não está certo? Já ele não. Ele é uma pessoa que não gosta de discutir, ele não fala sobre HIV, ele não fala sobre preservativo, ele não gosta de se cuidar. Não é que ele não gosta de se cuidar, ele acha que doenca pra ele é coisa assim, é muito feio, é muito ruim, é uma coisa que não deve nem tocar no assunto.

E: Ele não deve nem tomar os remédios.

C. E... O médico dele passou para ele fazer os exames de CD4, essas coisas e ainda não chegou o resultado. Mas acusou que ele está com o virus da Hepatite C. Então assim, agora ele já não bebe mais. Pra mim foi como (tossiu), como a certeza de que ele quer se cuidar mesmo. Entäo ele já não bebe mais, porque o figado vai inflamar, sei lá. Mas ele não é uma pessoa que vai mudar porque é bom pra mim, é bom pra vocé. Não. Ah,não hoje não tô a fim. Então pode usar o meu? Você pode usar, na hora não consegue, na hora não quer, sabe assim?

E: Vocé diz o preservativo feminino?

C: É.

E: Mas é isso que eu estava falando. Tem outras coisas envolvidas, não só vocé vai falar, usou preservativo? Nãol Então está erradol Tem outras coisas envolvidas. Você falou, às vezes você quer agradar...

C: Não quer discutir, então...

E: E ál, e se você engravidar de novo?

C: Eu uso pilula também.

E: Vocé quer ter outro filho?

C:Nāo. Prefiro não correr risco.

E: Por que?

C: De ele também ser... Ser... Infectado.

E: Então você não quer correr risco de ter uma criança com HIV.

C: Eu não quero porque eu já tenho muita expectativa $\theta$ seria mais uma e uma muito perigosa pra mim, entendeu? É muito risco'(p. 13-14) 
No quinto mês da gestação, Celina foi encaminhada para Avaids. Ela afirma que se beneficiou bastante com esse encaminhamento.
"E(...) Como você conheceu a Avaids?
C: A nutricionista me encaminhou pra cá. Primeiro foi assim, ela falou que a situação não tava boa. Não está ainda. Ela falou que tem esse leite daqui mas só que o bebé vai precisar de um leite mais forte, né? A Avaids ajuda a mãe, as gestantes, né? Então você pode ir lá se informar.
E: Você veio e estava em que més?
C: Eu estava no quinto mês da gravidez. Al eu comecei a participar em grupo.
E: E o que você achou de participar de grupo, de conversar com as pessoas?
C: Eu comecei a compartilhar o que eu estava sentindo. Porque antes eu não compartilhava com ninguém. Nem com meu marido.
E: Há quanto tempo ele saiu da prisāo?
C: Ele saiu quando eu estava com oito meses.
$E$ : $E$ nesse periodo, do quinto, de quando você veio aqui, ao oitavo mês, vocé tinha com quem compartilhar.
C: Aqui, porque eu também comecei a passar com a Psicóloga no Campos Eliseos. Era só com ela e com vocês.
E: Foi importante?
C: Pra mim foi, senão eu teria enlouquecido. Foi muito importante" (p. 4-5).

No dia do parto, houve uma mudança de planos: ela havia sido encaminhada para ter seu filho no Hospital da Vila Cachoeirinha, mas, quando sua bolsa rompeu, decidiu ir para a Santa Casa. Celina já tinha recebido o kit de prevenção da TMI e entregou para a equipe, mas eles demoraram a tomar as medidas de prevenção, o que deixou Celina muito preocupada, pois ela sabia que, se ficasse mais que quatro horas com a bolsa rota, o risco de TMI aumentaria. Foi um momento muito angustiante e, quando ela se revoltou, a equipe mobilizou-se. "Eu comecei a ficar apavorada porque se a bolsa ficasse rota por mais de quatro horas, havia mais risco, né?" (p. 10)

No pós-parto, Celina ficou muito aflita com o fato de que as outras mães puderam ter alojamento conjunto, enquanto seu filho ficou no berçário, fazendo exames e tomando remédios. Ela temia que alguém fosse "tomar seu filho" e, por isso, chorava copiosamente. Ela havia amamentado seu primeiro filho e se sentiu culpada por não poder amamentar o segundo filho, mas, segundo ela, teria se sentido ainda mais culpada, caso seu filho tivesse nascido "doente".

Ela havia afirmado que não gostaria de ter mais filhos em função do risco de que ele pudesse nascer infectado, mas, depois, posiciona a questão de outra forma: a sua decisão de não ter mais filhos está ligada a dificuldades financeiras.

E: Muito bem, então você estava falando que você já pensava em ser mãe. Quando você teve o primeiro filho já queria ser mãe e quando veio o segundo, foi porque queria ser mãe de novo. E vocé contou que não quer ter outro filho em função também do HIV.

C: Também, não seria o maior obstáculo porque eu poderia me cuidar, apesar da chance de ele nascer infectado.

E: Qual seria o maior obstáculo?

C: A situação financeira" (p. 17-18). 
Sua familia desconhece que ela tem HIV, com exceção de sua irmã. A posição deles é que ela não deveria ter filhos, em função de dificuldades financeiras. A posição de Celina, quanto à possibilidade de revelar ao filho sobre seu estado sorológico, é contraditória: ela diz que não terá problemas para contar, mas reage, com um "Deus me livre!" ao pensar que ele já pode saber da verdade. Parece haver, mais uma vez, um pacto de silêncio. Também chama nossa atenção o significante que ela usa: "recriminados". O mais comum é o uso da palavra "descriminados".

"E: Você acha que teu filho tem alguma consequência para ele, mesmo para o teu filho mais velho, o fato de ter uma mãe portadora do HIV?

C: Uma mãe...

E: Ou uma mãe e um pai?

C: Na minha cabeça sim, porque é tipo assim, não to segura...Ninguém $\theta$ segura de que vai viver muito tempo, né? Eu posso atravessar ali e morrer agora. So que pra mim é assim, eu posso chegar às oportunistas, rápido, e eu morrer e eles ficarem sem mãe. Ou tipo, eles podem ser recriminados, se um dia eles souberem. "Oh, sua mãe é portadora do HIV". Hoje eu já passo muita informação para o de dez anos.

E: Ele sabe?

C: Não, Deus me livre!

E: Por que?

C: (risos). Porque ele ainda não está preparado para receber essa noticia.

E: Mas você está preparando?

C: Um dia eu vou ter que falar, eu estou preparando.

E: Como é que se prepara uma criança para receber uma noticia dessas?

C: Olha, meu filho tem onze anos e se vocé conversar com ele você pensa que ele tem dezesseis. Ele é muito inteligente, aquela coisa de adulto. De sexo eu já converso com ele. E conto que tem que fazer com camisinha, tem a hora certa. Não se sabe com quem vai fazer, mas quando chegar a hora tem que estar preparado, com camisinha dentro do bolso, da carteira...

E: Ele já tem?

C: Não. (risos). Não, ainda é muito cedo. Ele fala assim, né mãe? Na hora eu vou saber? Então tá borm, na hora eu vou saber.

E: Mas na hora?

$C: E$, na hora quase ninguém sabe, né?" (p. 15-16)

Outra contradição surgiu, quando ela referiu que a decisão de uma mulher soropositiva ter filhos é pessoal, mas, por outro lado, ela parece adotar uma postura de julgamento moral: a mulher soropositiva cometeu um ato incorreto, "incapacitando" sua função reprodutiva, que seria um "dom dado por Deus". Como conseqüência disso, a mulher deveria ser punida.

"E: Eu estou te perguntando essa questão porque olha só, algumas pessoas na sociedade acham que as mulheres portadoras do HIV não deveriam ter filhos. O que você acha disso? Pelo risco dela transmitir ou pelo risco dela adoecer? O que você acha?

C: Por uma parte eu concordo, por outra não. Por que o fato de você gerar uma vida é um dom. Ser mãe. Muita gente faz tratamento, muita gente não pode ter. É um dom. Deus te deu aquele dom, mas você incapacitou.

E: Incapacitou?

C: Ou dificultou.

E: Incapacitou ou dificultou.

C: Dificultou. Então a culpa é sua. Deus te deu o dom de ter filho. Mas eu acho que deveria. 


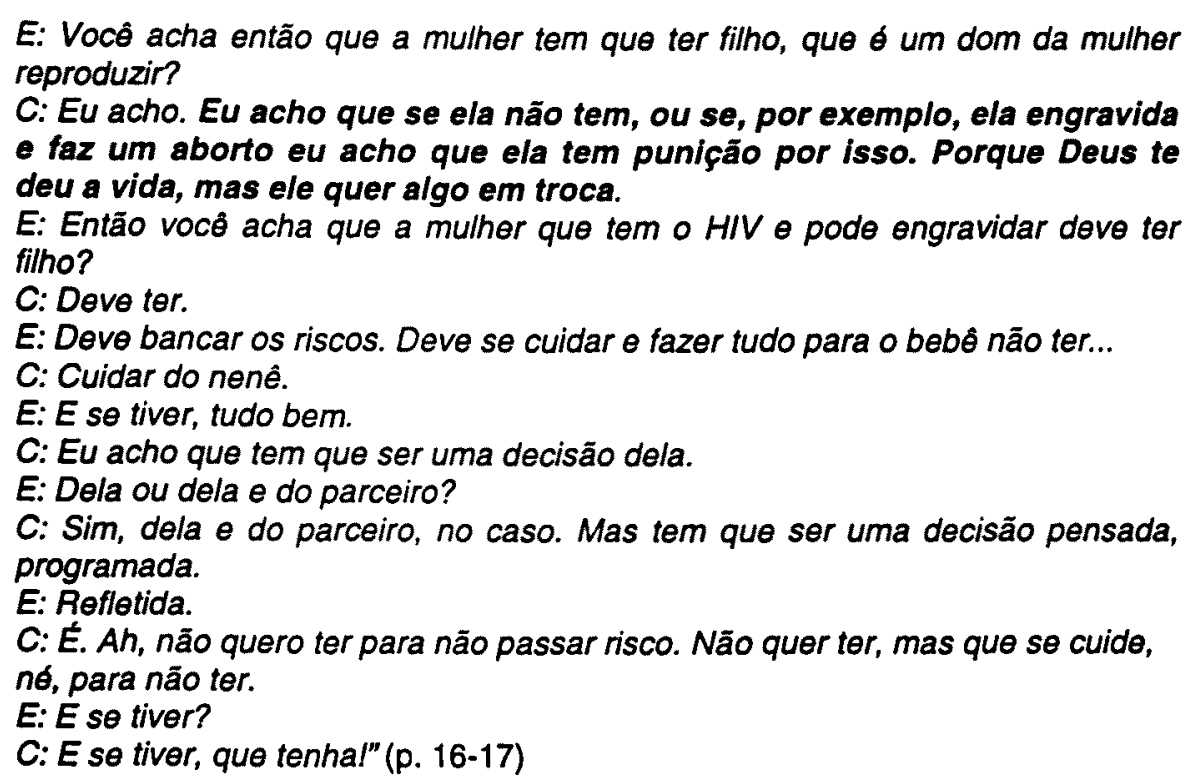

Por fim, ela admitiu que a relação com seu companheiro se modificou, após o nascimento do filho, e ela concluiu, dizendo que seu filho é um "troféu".

“O fato de ele (o filho) estar bem, melhor ainda. Um troféu. ' p. 20).

A entrevista, com Celina, chama nossa atenção, por vários aspectos. Parece haver um pacto de silêncio entre o casal, algo que permeia a relação, antes mesmo de ela engravidar. Há o relato de várias doenças infectocontagiosas (sexualmente transmissiveis), como sífilis, HIV e Hepatite C, mas - casal não parece ter adotado um comportamento de prevenção, quanto a isso. Celina afirmou que prefere "ceder para não discutir", mas ela mesma se contradiz, ao dizer que tem momentos em que quer se prevenir e tem momentos que "não quer". Esse "querer e não querer", associado ao silêncio, parecem configurar uma questão, que gera angústia.

Seu discurso é permeado por várias contradiçōes: querer e não querer usar preservativo; dizer que não quer filhos, por causa do HIV, e, depois, afirmar que o que determina sua decisão são dificuldades financeiras; em alguns momentos, ela é favorável a que uma mulher soropositiva tenha filhos e, em outros momentos, julgar moralmente essa decisão, entre outros. Ela não quer "correr riscos", mas seu comportamento é sempre permeado pelo risco: o risco de ser infectada por uma doença sexualmente transmissivel; o risco de engravidar; o risco de ter um filho soropositivo; o risco de relacionar-se com um companheiro, que se "arrisca", próximo ao mundo do crime.

Para ela, ter um filho é um "dom dado por Deus" e a mulher que não se comporta adequadamente ("que não usa preservativos") comete uma espécie de pecado, pois "incapacita" suas funções reprodutivas, que deveriam funcionar perfeitamente (segundo o dom divino) e, finalmente, deve ser punida (o HIV é a punição). 
Celina relatou uma série de "medos": medo de perder novamente o marido, medo de que seus dois filhos ficassem órãos de pai, medo de que ela viesse a morrer, antes mesmo de dar à luz (o que inclui o medo de que seu filho venha a morrer, também) e medo de que alguém venha tomar seu filho (no pós-parto). O que chama nossa atenção é que, no registro de suas perdas, há uma questão de punição. Em seu discurso, ela parece assumir, tanto a posição de algoz, quanto de vítima. A forma, como ela julga o comportamento de uma mulher soropositiva é, enfim, a forma de como ela se vê.

Seus filhos poderiam ser "recriminados". Esse significante merece atenção: não seriam "des-criminados"? Parece que surgiu, em sua fala, algo da ordem do "re-crimidados", como se lhes fossem imputados "novamente um crime". Mais uma vez, a temática "crime/castigo" se presentificou.

Também, é interessante lembrar que a descoberta do HIV se deu no momento em que seu marido cumpria pena e estava preso (ele foi, portanto, condenado). A "condenação", na forma do HIV, aconteceu, concomitantemente, à condenação do marido. Parece que ambos cometeram um crime. Do lado de Celina, qual poderia ser o crime? Sua irmã era a "namoradeira" e escapou ilesa. Então, ela se pergunta: "por que eu? Por que comigo?".

Podemos ver que há um sentido em seu discurso. Entretanto, não podemos deixar de notar que há um "mais além", ou seja, há algo no comportamento de Celina, que indica um "sem sentido". Por que tanta contradição, silêncio e julgamentos? A psicanálise nos ajuda a pensar que aí, nesse lugar do silêncio que coloca em perigo, há o desejo e o gozo. Nesse lugar "sem sentido", o sujeito se coloca assujeitado e tragicamente implicado.

Celina nos relembra que, embora o relato de sua história nos remeta à tragédia, o final é feliz: ela conseguiu o seu "filho-troféu". O que faz de seu filho um troféu? A superação do HIV, pois ele não nasceu com o vírus. 


\subsubsection{4 - Maria: que não tem nada para perder}

Síntese: Maria tem um filho de 11 meses (HIV-) e está grávida. Ela tem 26 anos e vive, em união estável, com um companheiro soronegativo. Declarou-se ex-usuária de drogas (crack e álcool) e houve o relato de violência doméstica. A atitude de Maria causa constrangimentos ao grupo que freqüenta (houve denúncias de que ela vendia o leite que recebia). A ONG pretendia desligá-la do serviço, quando ela comunicou que estava grávida, novamente. Seu relato traz, repetidamente, o significante "fome", e Maria afirma que "vou ter quantos filhos eu quiser".

Figura 21 - Diagrama da linha narrativa relativa à entrevistada Maria

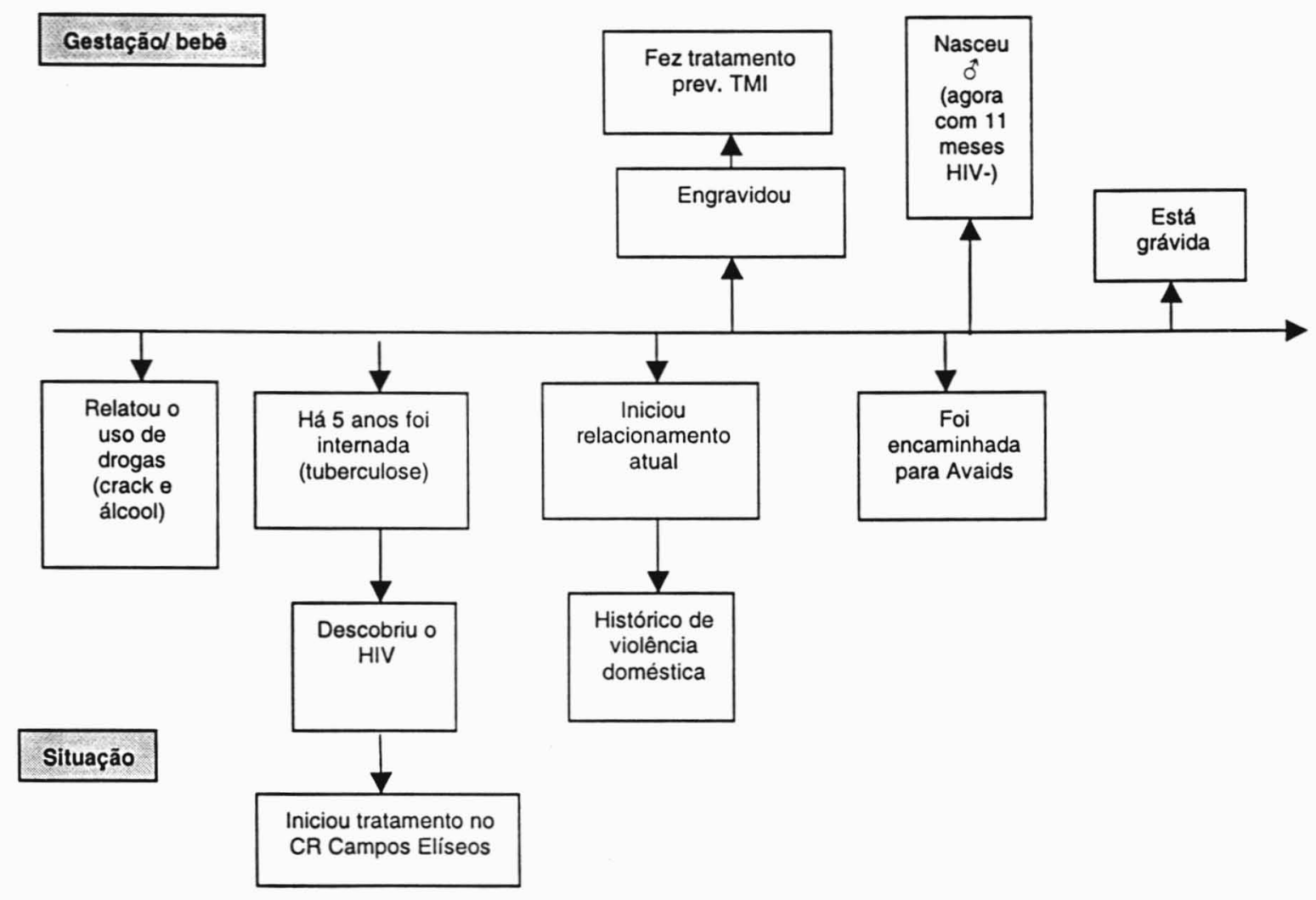

Maria tem 26 anos, e está grávida. Ela tem um filho que, recentemente, completou 11 meses. O seu relato é bastante confuso, não há precisão de datas e observam-se algumas incongruências. Ela relatou que usava drogas (crack e álcool) e que, certa vez, muito emagrecida, ficou doente e foi internada, com um quadro de tuberculose. Descobriu, na época, que tinha o HIV. Mediante tal notícia, assim que saiu do hospital, foi usar drogas, dizendose desesperada. 
Maria contou que, sempre, desejou ter um filho, mas, na época em que recebeu o diagnóstico de HIV, sua médica the disse que ela nāo poderia ter filhos, em função do HIV. Ela planejava, então, adotar uma criança, e, quando engravidou, considerou isso um milagre.

\section{"E: E como faz para arrumar um filho?}

M: Eu pensei desde menina. É um milagre.

E: Milagre? Será que é milagre mesmo?

M:É. Eu ia assim pegar uma criança nessas casas de gente que tem criança $e$ eu ia pegar pra mim. Eu falei, eu não posso ter o meu de dentro da barriga, eu vou criar um filho. Ele (o atual companheiro) falou, Maria, pensa um pouco, dá mais um tempinho.

E: E por que você achava que não podia ter um filho?

M: é porque a médica falou que eu não posso ter um filho porque sou soropositiva. É muito arriscado você ter filho.

E: Que médico disse isso?

M: A Dra Glória, infecto. Ela disse que ter filho era muito perigoso e ele podia ter HIV. Eu pensei, tá bom. Deu um tempo e eu falei, amor, embora pegar um filho pra nós criar. Ele disse agora não, espera um pouco. Espera um pouco? Logo veio esse moleque lindo. (risos)

E: Vocé achava importante ter um filho..

M: Eu achava importante porque.... Eu disse, eu quero. Al eu disse, já resolvi o meu problema. Pronto! Vamos fazer o papanicolau. Al eu fiz o papanicolau, eles passaram cinco remédios para mim tomar e cinco pro meu marido. Eu disse, toma esses remédios ai, quem sabe a gente engravida. Eu tomei o remédio, passei a pomada tudo, que eu tava com um pouquinho de infecção, ai no més de... nem sei que mês eu fiquei grávida, entendeu? Al não desceu pra mim, no outro més não desceu pra mim e eu falei, pronto. Fui no médico, fiz exame de urina. Deu positivo. Eu falei, ai, aleluia, Jesus!" (p. 7).

Seu companheiro não é soropositivo, mas aceitou, sem problemas, o fato de ela ser soropositiva. Ela relatou situações de violência doméstica, e é interessante notar que, recentemente, quando o marido soube que ela estava grávida, deixou de ser agressivo com ela.

"E: E como é que foi, quando você soube que estava com o HIV e grávida? M: É que ele me chamou para morar com ele e eu falei com ele que não podia (ter filho) porque era soropositiva e ele perguntou "o que é soropositiva?". Al eu falei para ele "eu sou doente da Aids". Al ele falou para mim, não importa não. O que importa é você tomar seus remédios, vocé se cuidar. $E$ eu falei, vou pensar no seu caso. Ai ele falou que até eu pensar, já arrumou outra mulher. Ai eu fui morar com ele e seja o que Deus quiser." (p. 2)

"E: $E$ quando vocé soube que estava grávida, como é que foi?

M: Eu não pensei nada. Tem que tomar os remédios direitinhos, tomar vitamina. Eu falei para Deus, seja o que Deus quiser. Se nascer positivo, negativo, não importa. Deus que vai julgar isso. Ele nasceu negativo, então..." (p. 3)

"E: $E$ como você está com seu marido hoje?

M: Eu tó bem. Assim que eu fui no posto. Ele me bateu. Eu fui na delegacia.

E: Ele bateu mais?

M: Não, o pessoal chamou a polícia para ele. A mulher falou, mãe vamos ali tirar raio $x$. Eu disse, não vou não. Eu acho que estou grávida. $E$ o policial falou, então deixa, não pode tirar o raio $x$. E o que vai fazer com o homem aí? Vai dar queixa, vai BO contra ele? Eu disse que vou fazer não, porque ele é 0 pai do meu filho, como vou fazer? Ai eu me mudei pra casa da minha tia de novo, fui embora. Ele foi atrás de mim, falou que nunca mais ia me bater, fez 
carinho e desse dia em diante nunca mais me bateu. A única coisa que ele faz é carinho" (p.9).

Durante toda a entrevista, Maria comentou que passava fome e que não havia comido nada. O suporte institucional (do hospital, das ONGs, do Centro de Referência em Dsts, entre outros) é a fonte de ajuda para sua alimentação e vestuário, tanto para si, quanto para seu filho. Quando engravidou de seu primeiro filho, conseguiu apoio de várias instituições e passou a fazer uso constante desses apoios. Diante de dificuldades, Maria não reluta em solicitar ajuda, e aproveita toda oportunidade de obter aquilo de que precisa.

\begin{abstract}
"E: O que você acha do acolhimento que você tem lá no lugar onde vocé fazo tratamento?

M: Lá é muito bom. Lá ninguém sabe, eu entro e sai, entro e saio. Eu vivo mais no posto do que em casa porque no posto tem alguma coisa para mim comer, né? Porque lá em casa nem sempre tem. Eu tó passando necessidade." (p. 4) "E: Mas vocé estava sentindo acho que melhor (no hospital do) que sua casa? M: Eu taval Tinha comida toda horal Quando a gente lá precisa de alguma coisa, aperta um botãozinho de chamar. Ai eu falei, eu queria que minha casa fosse assim. (risos) Lá a menina, a copeira trazia só um pãozinho na hora do café. Ela dizia que ia me dar mais um porque o pão ia tudo para o lixo. Então eu falei "me dá, se for sobrar vocé deixa aqui para mim". Quando eu acordava já tinha um lá pra mim. Quando eu for embora vou sentir muita saudade de vocel" (p. 4)

"E: Como é que você acha que está hoje?

M: Eu estou bem. Eu não estou passando fome dessa vez. Eu chego num lugar peço roupa, comida. Eu fazia faxina e eu dia eu parei porque não agüento mais" (p. 9).
\end{abstract}

Embora receba o suporte institucional, de que tanto necessita, quando seu filho nasceu, Maria teve medo de que alguém the tomasse o filho. Chegou a ficar com medo de sair de casa.

\begin{abstract}
"Eu passava o dia todinho lá, almoçava lá mesmo $\theta$ a noite, umas seis horas meu marido vinha me pegar. Ele vinha umas trés horas visitar e dizia que depois mais tarde vinha me pegar. Depois que eu ganhei o menino parece que eu fiquei com medo de sair na rua. Tive um medo de sair na rua, sei lá, alguém ia pegar meu filho. Passei um bom tempo sem sair para a rua depois que ele chegou em casa. Ficava com medo que alguém pegava meu filho (riso nervoso)" (p. 5).
\end{abstract}

Quanto ao seu tratamento e à relação com a equipe, que a acompanha, ela relatou que tem algumas dúvidas e dificuldades. Ela não consegue compreender aquilo que o médico, que a atendia, falava e, atualmente, sentese melhor com outra médica, pois esta a examina e the explica o que está acontecendo. Ela apontou que tem dificuldade em seguir, adequadamente, 0 tratamento (adesão), em função da dificuldade alimentar.

\footnotetext{
"E: Mas quando você conversa com a médica, o que ela diz? Como ela diz que vocé está?

M: Agora que eu vou passar para a Dra Iná, está me entendendo? Antes eu passava como o Dr João Paulo. Ele só passava um papelzinho lá para fazer exame e pronto. Nunca me examinou, nunca fez nenhuma pergunta aquilo...

E: Ele é infectologista?
} 
M: É. Agora eu mudei para a Dra Iná. Ela é que cuida da gente, agora que eu vou saber o que é Carga Viral, CD4. Eu vou chegar para ela e perguntar. Ele só falava que a Carga Viral está boa. Eu não entendia nada que o homem falava!

E: Mas vocé sabe como é que você está hoje, em relação o HIV? Se está bem?

M: Ele não me fala. Ele só falou que eu estou emagrecendo. Eu falei, olha Dr. João Paulo, emagrecimento não é minha culpa não porque o remédio eu tomo certinho. Mas eu vou comer alguma coisa lá pra meio-dia. Mas meio dia e meio eu tomo remédio, com um café. Puro, com água, não desce de jeito nenhum..." (p. 5).

Maria relatou, ainda, que, nesta gravidez, prefere ter uma filha, pois acredita que a filha é a companhia da māe, e o filho, a companhia do pai. Ela também apontou sua versão para uma questão cultural: a menina começa a vida sexual, precocemente, por ser "mais fogosa" que o homem e, justamente, por isso, deveria ser mais controlada pela mãe.

"M: Eu só ouvi a mulher falando "mãe, é um machãol". "Machão". Tá vivo ou tá morto? Na hora eu desmaiei porque tava anestesiada. Seja o que Deus quiser desse daqui (coloca a mão na barriga), se for menina eu vou ficar mais feliz. E: Por que?

M: Por que esse daqui (aponta para o bebe) quando tiver um ano e meio vai ser mais o pai, então se vier uma menina, vem para me ajudar. Eu faço as minhas coisas, ela faz as dela, entendeu? Menina a gente tem que segurar dentro de casa, se não, solta a perereca por aí.

E: A menina solta a "perereca"?

M: Quando chega os 10 anos já quer soltar o fogo no meio da rua...

E: 10 ?

M: Dez anos. Lá no norte é assim. No Ceará é assim. A menina já sai querendo dar pros homens..." (p. 4).

A gravidez parece ser um momento muito importante para Maria, pois se ela nada tem a perder, quando está grávida, o marido nāo a agride e faz carinho. Ela pode dar-se, também, a alguns luxos, como comer o que deseja. Para ela, comer é um luxo, e o filho é seu companheiro. Ter um menino e, depois, uma menina, seria a felicidade "completa".

"Sei lá, pra mim foi muito bom, minha gravidez... Não senti dor nenhuma, só vi ele se mexendo dentro da barriga, que é que eu tenho a perder?" (p. 4)

"E: Maria, e o que é para vocé "ter um filho"?

M: Ah, pra mim é uma felicidade. Que nem, eu tó com um filho, agora já vem mais outro. Seja o que Deus quiser. Se for uma menininha vai ser uma felicidade completa.

E: Completa? Como assim, completa?

M: Porque o menino é mais o homem e agora eu quero uma menina pra mim. E ai vai estar completa. Ele é o pai e tem, e eu vou ter também. O primeiro filho a gente gosta mais, um menino, é tudo novo. Dai a filha, a gente gosta muito mais. O menino já tem ciúme da mãe. Este já sente ciúme de mim. Quando o pai vem, ele tira a mão dele de lado. Ele sente muita falta de mim. Mas ele já está sentindo o meu que está dentro da barriga. Ele já está crescido e vai ficar mais o pai dele. E eu vou ficar sozinha?

E: Então ter um filho é alguém para dar atenção...

$M: E$ contar, normalmente $\theta$ isso....

$E: E$ o que é para você "ser mãe"?

M: Ser mäe como? 
E: O que é ser mãe? Se ter um filho é "uma felicidade", o que é ser mãe?

M: é muito bom, é ter alguém dentro de casa. Eu converso com ele o tempo todo. Ás vezes chega alguém e pergunta "vocé tá conversando com quem?". Eu respondo que estou conversando com meu rapaz, meu lindo, gostoso. Al oh? Meu nenê...

E: Ele é seu companheiro?

M: é meu companheiro. Eu fico conversando com ele... ele me entende.

E: Ele te entende?

M: De pouquinho em pouquinho, vai me entendendo. Não bato nele. Por que o filho da gente não é para bater, apanhar. Porque quanto mais vocé bate, 0 próximo que bater, ele bate na próxima, entendeu?

E: Maria, e você acha que é diferente "ser mãe" $\theta$ "ser mãe portadora do HIV"?

$M:$ Não, é a mesma coisa. A única coisa é que não pode dar de mamar.

$E$ : $E$ isso não importa? A experiência é a mesma?

$M:$ Só de ver teu filho, ser māe... Está bom demais" (p. 6-7).

O fato de Maria ser soropositiva, não apenas lhe garante o acesso à assistência social para seu filho, mas também, acesso a benefícios do governo. Ela espera conseguir aposentar-se e, mediante o recebimento de alguma renda fixa, poder garantir algum bem para seu filho.

Quando Maria foi ao posto de saúde, para realizar os exames para confirmar sua segunda gravidez, sentiu necessidade de se justificar: estava grávida, porque "aconteceu", ou seja, não foi uma decisão de sua parte. Embora o casal seja sorodiscordante, o uso de preservativos é esporádico e ela relata que, muitas vezes, o preservativo estoura. Na entrevista, ela disse que não pretende ter outros filhos, mas deixa claro que não mudará seu comportamento sexual, quanto à contracepção.

"E: E como você acha que as pessoas te olham hoje? Pelo fato de ter tido um filho sendo portadora do HIV, agora pode estar grávida sendo portadora do HIV?

M: Me talaram lá no posto de saúde. Eu disse, aconteceu! Seja o que Deus quiser. Eu me trato, dou comida pra ele, dou mamadeira. Ele nāo tem nada... 10 bebé chamou a atenção)

E: Voce pretende ter outros filhos?

M: Não... Mas seja o que Deus quiser. Se vir os filhos. Meu marido falou, a casa cheia. Está bom demais...

E: E vocé pretende evitar filhos como? Usar preservativo?

M: Eu nāo uso preservativo... Assim, se estourar estourou. Tem hora que o negócio parece que nāo cabe ali no pinto. Eu tive o primeiro, tinha estourado ali na hora. Eu não uso camisinha. Se estourar estourou.

E: Estoura muito a camisinha?

M: Sim, tem hora que não cabe no pinto. Acontece sempre." (p. 9).

A familia de Maria desconhece que ela é soropositiva e, embora não sejam próximos, Maria apontou que sua mãe desejava que ela se tornasse mãe. Ter um filho é a garantia de continuidade da família.

"E: E para sua familia, ter um filho tem alguma conseqüéncia?

M: Para minha familia não tem... tem... porque ela (sua mãe) queria muito que eu fosse mãe. Eu queria que minha mãe tem um neto. Ele é neto. Quando elo casar, vai ter um filho, é bisneto pra mäe, não é?

E: É uma continuidade...

M: é... continua (gesto). E a avó tem um bisneto e eu tenho um neto." (p. 8). 
Ao final da entrevista, Maria perguntou se o que ela disse "foi alguma coisa que prestasse", sendo que parecia importante, para ela, que não falasse nada errado. Seu comentário final exclui o companheiro, mas inclui o bebê, que ela espera e supõe ser uma menina.

"M: Eu falei alguma coisa que prestasse? (risos)

E: Tem mais alguma coisa que você queira acrescentar?

M: não. Eu quero dizer que eu meu filho, minha filha que vier, que nóis seja muito feliz" (p. 10)

A entrevista de Maria nos faz pensar que se trata de uma pessoa, com vivências, que apontam para problemas na obtenção de satisfação de necessidades básicas. Ela parece dar-se conta de que the faltam muitas coisas, e afirmou "que é que eu tenho a perder?". O que se evidencia é que uma pessoa, que nada tem a perder, na verdade, nada possui. Parece ser, exatamente, esse o modo, que ela construiu, para sobreviver: faltam-lhe tantas coisas, que, o que vier, é lucro. Mas ela não espera sentada, pois ela sabe que precisa "correr atrás" daquilo, de que ela e seu filho precisam.

Quando seu filho nasceu, sua primeira fala "tá vivo ou tá morto?", seguida de um desmaio, que ela atribuiu à fome, pode ajudar-nos a perceber o quanto é difícil o processo de simbolização, apontando a crueza do Real.

Maria parece delegar ao Outro a condução de sua vida: ela engravidou por "acidente", pois o "preservativo sempre estoura" e, além disso, coloca tudo nas mãos de um Outro, representado na figura de Deus ("seja o que Deus quiser", "Deus vai me curar", etc).

Cabe, aqui, explicitar que Maria freqüenta o grupo de mães na ONG Avaids e costuma causar polêmica. Ela costuma solicitar ajuda das outras mães: não leva alimentação para o filho, nem fraldas ou roupas. As mães parecem censurar a atitude de Maria, mas se comovem com a situação e a ajudam como podem. Houve a denúncia de que ela teria vendido o leite, que recebe na Avaids, para outras mães, passando a dar "água de arroz para a criança". Isso gerou revolta no grupo, o que fez com que a psicóloga da instituição intervisse e entrasse em contato com a assistente social do CR, onde ela faz tratamento.

A psicóloga da Avaids iniciou atendimento psicoterapêutico individual com Maria, pois ela causava muita polêmica no grupo de mães. Mas Maria não comparecia aos atendimentos e solicitava atenção especial durante o horário do grupo, burlando as regras da instituição. Em virtude dessas dificuldades, a psicóloga decidiu desligar Maria do serviço, o que gerou grande comoção e revolta de sua parte. No dia em que a psicóloga pretendia comunicar que ela seria desligada do grupo, Maria informou, triunfante, que estava grávida, novamente. Ela foi, então, novamente, acolhida pela instituição. Maria gritava em altos brados "vou ter quantos filhos eu quiser, quero ver quem vai me tirar daqui!". 
Podemos observar, através desse relato, que, embora seja fundamental o suporte institucional, para garantir a satisfação das necessidades básicas da população, isso, nem sempre, é algo fácil de ser realizado, na prática. Muitas vezes, 0 beneficiário invoca seus direitos e não consegue cumprir com os deveres, que assume, ao ingressar no grupo, burlando as regras, ou, usandoas em seu favor, quando the interessa. O caso de Maria aponta para o impasse que a instituição vive, quando se depara com o sujeito que não "se conforma", pelo contrário, desafia e desacata a autoridade, assumindo uma posição de manipulação da piedade do outro. O que se destaca é o relato de alguém que, para sobreviver, faz de tudo, pois nada tem a perder.

Observamos, então, um sintoma, não apenas pessoal, mas também institucional. A fala final de Maria "falei algo que prestasse?" aponta para um sujeito que quer, sobretudo, garantir um vínculo com o Outro, ser aceito, ser amado. Ela não parece dirigir-se ao outro/Outro, desvinculada desse desejo, pelo contrário, o fato de ser capaz de manipular o comportamento do outro só deixa claro que ela tem habilidades para perceber, ou supor, o que o Outro quer dela. Mas, não podemos deixar de lembrar que, na relação do sujeito com o Outro, há, sempre, o desencontro das demandas, ou seja, um equívoco, que gera conseqüências. É, justamente, desse "desencontro" que a instituição não dá conta: Maria reage, supondo que o Outro quer dela um determinado comportamento (nāo burlar as regras), ou situação (que ela esteja grávida). Evidencia-se que Maria, mais uma vez, coloca-se nas mãos do Outro, oferecendo-se ao que ela supōe ser o que o Outro quer dela e, assim, procura garantir seu lugar nesse grupo.

Sua atitude gera conseqüências, não apenas para ela mesma, mas também, para seu filho. Lembramos que ela teve medo de que alguém the tomasse o filho. Embora ela afirme que "nada tem a perder", ao se colocar na posição de vítima, ela faz com que a falta do Outro se evidencie, e, por meio disso, acaba por inverter a situação: ela provoca no outro a idéia de que ele the deve algo e, assim, ela se preenche dessa suposta divida simbólica. 


\subsubsection{5 - Márcia: que associou o nascimento de alguém com a morte de outra pessoa.}

Sintese: Ela tem dois filhos (uma menina de 10 anos, HIV-e uma menina de 6 meses, HIV-). Aos 26 anos, trabalha como atendente, em um bar. Recebeu a noticia do HIV, quando estava grávida de 5 meses, quando fazia 15 dias que seu primeiro companheiro havia falecido. Teve 3 companheiros: dois faleceram e um a abandonou, grávida. Relato de vivências repetidas de perdas de companheiros e familiares, bem como a associação de morte, concomitante a nascimentos. Relatou uso abusivo de bebidas alcoólicas. Ela não quer mais se envolver, afetivamente, com outros homens, por medo de novas perdas.

Figura 22 - Diagrama da linha narrativa relativa à entrevistada Márcia

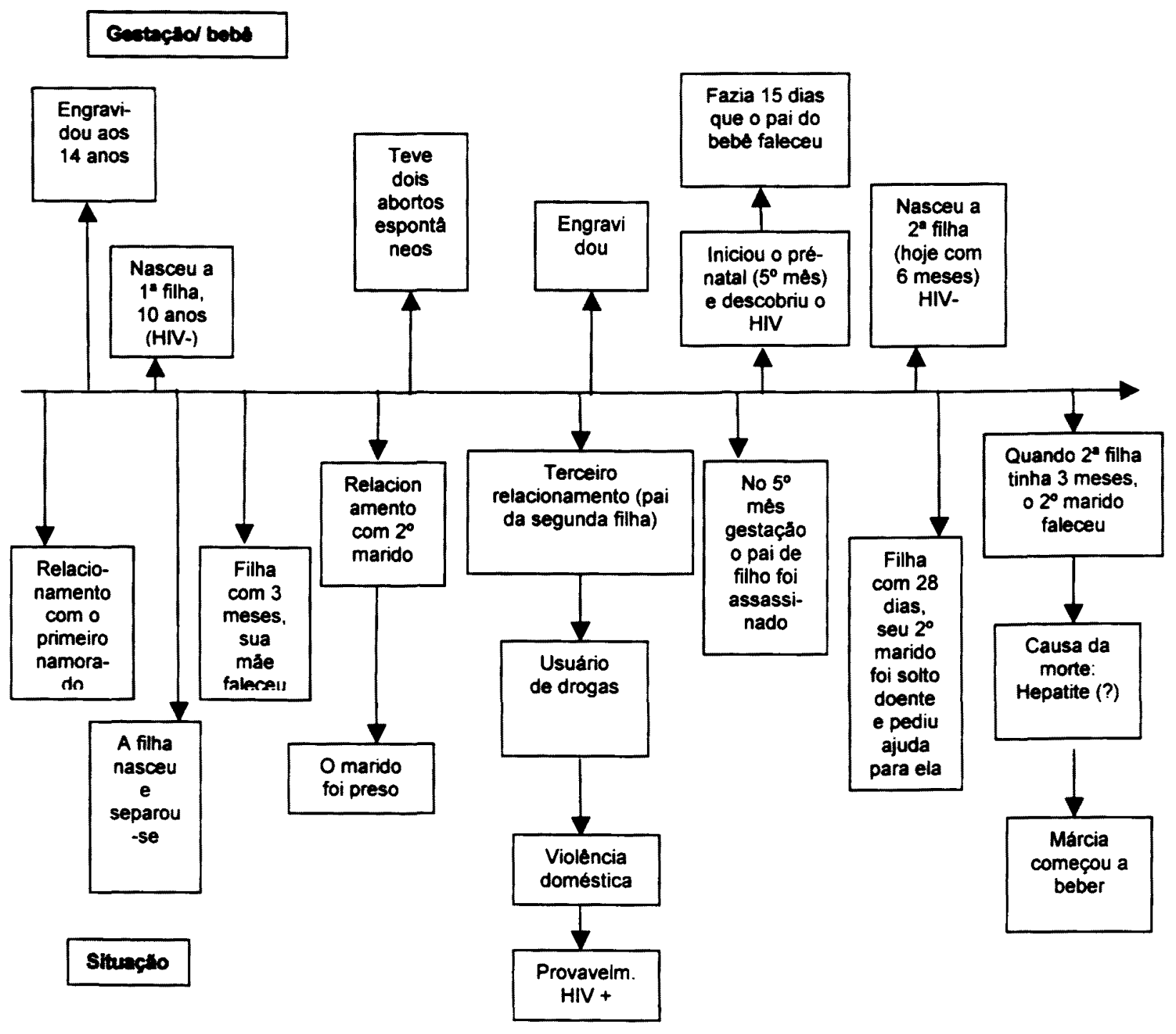


Márcia tem 26 anos e duas filhas: a primeira, tem dez anos e a segunda, seis meses de idade. Aos 14 anos, engravidou de sua primeira filha, e o pai do bebê era casado, deixando-a sozinha. Quando sua primeira filha tinha três meses de idade, sua mãe faleceu. Algum tempo depois, iniciou outro relacionamento com um homem, a quem considera o "grande amor de sua vida". Esse segundo companheiro a ajudou a cuidar de sua primeira filha $e$, depois disso, ele ficou preso por, aproximadamente, três anos e meio. Houve, entāo, um outro relacionamento, que durou seis meses, do qual nasceu sua segunda filha. Márcia estava com quatro meses de gestação, quando o pai desse segundo bebê foi assassinado. Ainda, sob o choque da perda, foi fazer 0 pré-natal no posto de saúde (15 dias após a morte do marido), quando recebeu a noticia de que seu exame, para HIV, tinha dado positivo.

"E: A gente ouve falar de HIV, mas...

M: Quando é com a gente é diferente, mesmo assim é outra coisa. Mas como eu te falei, eu năo pensei na minha filha, no meu bebê, eu năo pensei isso. Eu pensei na outra.

E: Ah, vocé pensou na sua filha mais velha?

M: Eu pensei nela.

E: E pensou como? Como ia fazer para cuidar dela?

M: Pensei, falo ou náo falo, se vou morrer amanhã, sabe? E ela vai ficar com quem? Eu pensei na mais velha, nåo na novinha" (p. 6).

"M: Fiquei quase doida! (risos) Fiquei anestesiada... Eu estou vivendo agora, agora eu estou vivendo. (...) Agora que eu estou voltando na vida" (p. 7).

"Foi muita coisa! Já grávida a gente fica meio sensível tudo. Pra mim foi uma bomba" (p. 14).

O relacionamento com o pai de sua segunda filha foi muito conturbado e pautado por violência doméstica. Ele era usuário de drogas, e Márcia suspeita que ele soubesse do HIV, e não lhe tenha contado. Ainda assim, eles tiveram relações sexuais, com o objetivo de ter um filho. Segundo Márcia, ela engravidou, para que sua filha tivesse companhia.

"E: E o seu terceiro companheiro, o pai da sua segunda filha, quando ele soube que voce estava grávida, como foi?

M: Ele também nåo esperava porque eu acho que ele já sabia que ele era HIV e ele sempre falava assim, ah você năo presta nem para ter um filho meu.

E: Ele sabia que ele era portador?

M: Ele sabia que ele era portador porque ele já tinha falado para outra pessoa.

E: Voce acha que ele te passou de propósito?

M: Eu acho assim, hoje eu entendo a reaçăo dele. Ficou acho que meio perturbado, ou ficou meio raivoso com ele mesmo e das mulheres. Quando ele saia e se envolvia com uma mulher, ele gostava e ao mesmo tempo ele tem ódio. Acho que aquele negócio de por pra... sabe aquelas pessoas que, como pode falar...ai meu Deus, escapou.

$E$ : Vocé acha que ele, não sabe direito o que quer? Se quer uma coisa ou se quer outra?

M: Năo, não é assim. Tipo assim, se vingar. Eu soube que eu peguei uma Aids com um cara e eu vou judiar dele, entende?

E: Entăo ele estava assim magoado, agindo com mágoa? 
M: Toda vez que eu saia com ele, ele me espancava...Ele nåo me espancava assim... Mas ele era agressivo, ficava bravo comigo, tentou me enforcar várias vezes, mas quando ele estava naqueles dias atacado.

(...)

E: E vocés não evitavam uma gravidez?

M: Năo, eu acho que eu já queria um nené. Não por ele, mas pela minha filha. A minha filha sentia muita falta. A minha gravidez mais... eu tava tentando ter filho, nunca conseguia (risos), quando eu consegui... ah, mas nem por isso. Eu fiquei grávida mais pela minha filha mais velha porque ela se sentia muito sozinha, ficava reclamando que os amiguinhos dela tinham irmăos e que fulano era assim e assado, sabe? Entáo eu fiquei grávida mais por ela, a mais velha, para fazer companhia para ela.

E: Entăo foi ela quem quis?

M: Ela queria ter um irmáo. Queria ter uma companhia" (p. 21-22).

Quando sua segunda filha nasceu, o seu segundo companheiro foi solto e a procurou, doente, pedindo que ela cuidasse dele. Poucos meses depois, ele faleceu. Ela passou, então, a beber.

"(..) No mesmo dia que eu enterrei ele, eu comecei a beber (risos). Juro por Deus! Eu falei, ai năo suporto mais isso e comecei a beber. Na missa de sétimo dia eu estava num pagode. (riso alto)" (p. 7).

"M: Ah, é muito dificil. Essas minhas relaçōes! Eu e os meus maridos! (risos). Quando eu vou para a igreja tem que acender duas velas, tem que mandar rezar duas missas para nenhum dos dois ficar brigando onde quer que eles estejam. (risos).

E: Eu acho que pelo contrário. Eu acho que eles estão lá cuidando de vocé.

M: Tá bom, ou então os dois estão brigando lá por mim. (nisos) Só eu mesmo! Vou ir para não chorar!" (p. 18).

Márcia relatou que não teve nenhum problema, com relação à equipe multidisciplinar, que a atendeu, sentido-se acolhida e recebendo todas as informações, que the proporcionaram tranqüilidade, para empreender 0 tratamento e esperança de que sua filha nasceria sem o vírus.

Quanto à questão da amamentação, Márcia contou que ficou muito triste por não ter amamentado a segunda filha. Em sua fala, destaca-se o significante "chorar por dentro". Perante questionamento das colegas de quarto, Márcia disse que seu leite tinha secado, em função da situação de perda do companheiro. Para ela, não poder amamentar é perder o "prazer de ser mãe".

\section{E: E como é que foi para vocé alimentar o bebê?}

M: Essa parte é muito... muito (riso nervoso). Muito triste (riso triste). Ah, nas primeiras horas de vida dela, na matemidade e ela chorava de fome e vocé lá com o peito cheio de leite e năo poder amamentar o teu filho. Ás vezes nem tá chorando com fome, mas tem que dar $30 \mathrm{ml}$ de leite a cada trés horas. $E$ vocé com o peito até poe toda hora. Mas naquele dia foi demais pra mim, até eu me acostumar. Mas era para o bem dela, eu não podia dar. Foi triste.

$E$ : E como que voce lidou com isso? Chorou, voce conversou?

$M$ : Ah, eu só chorava por dentro, né?

E: Como é chorar por dentro?

M: Acho que é a tristeza, aquela coisa de ver o teu filho, né? De ver outras máes dando o peito para o filho. De ver que aquela alimentaçăo 
no peito é saudável e você não poder. "Mas porque vocé não dá o peito para sua filha?". Secou, porque eu passei uma crise, o pai dela... entăo secou. Mas foi horrivel.

E: Foi nessa hora que você sentiu alguma diferença?

M: Foi.

E: Voce falou, não tem diferença, mas nessa hora...

M: (risos) Nessa hora você sente.

E: Tem o peito saudável e tem o peito năo saudável?

$M: E$. É chato. Essa é a parte horrivel.

E: Essa parte te magoou pelo jeito.

M: É. Dói. Não é à toa, a gente sente. Na primeira eu dei mamar. Entăo dó, vocé sente o peito inchado, vocé nem consegue amamentar. É o prazer de ser mãe" (p. 9-10).

No oitavo mês de gestação, a nutricionista do Centro de Referência a encaminhou para Avaids, o que, segundo Márcia, foi fundamental para que ela obtivesse apoio psicológico. Embora, inicialmente, tivesse procurado a Avaids, pela necessidade de leite para sua filha, aos poucos, foi percebendo a importância do trabalho psicológico.

Mácia apontou que suas filhas são sua razão de viver e que as dificuldades cotidianas são superáveis. Seu relacionamento com a primeira filha ficou, inicialmente, abalado, quando ela soube do HIV, pois ela temia que pudesse infectar, acidentalmente, sua filha. Aos poucos, mediante informação adequada e acompanhamento psicoterapêutico, esse medo foi superado.

\section{"E: E como é que está o seu bebê?}

M: A segunda? Ai, tá linda. (risos). Está grande, muito esperta, uma saúde de ferro. É a razăo para mim continuar a viver. São a minha vida.

$E$ : Suas filhas săo a sua razáo para vocé continuar a viver.

$M$ : Săo a minha alegria, apesar das briguinhas. (riso). As raivas, mas isso é normal.

E: Que raiva?

M: Ah, manha. Brigar por causa disso ou daquilo. Coisa de filho mesmo.

E: Coisas da convivência mesmo?

M: Năo é? Mas tirando isso as duas săo a minha razão de vida, as duas." (p. 2).

Márcia não parece ter se posicionado, claramente, a respeito da maternidade e justifica isso, ao contar que teve sua primeira filha aos 14 anos ("muito jovem") e, hoje, mediante tantos transtornos, ainda não conseguiu dar um sentido para a questão, dizendo-se "traumatizada com filho". Como ela disse, "eu sou mãe, mas não me sinto mãe", ou, "esse negócio de "mãe" machuca, porque eu não me vejo como mãe. Eu sinto mais falta da minha mãe, ele lembro da minha mãe. É mais doloroso para mim"; "eu não sei o que é ser mãe". Ela, também, associou a idéia de que, ao ter um filho ou ao nascer alguém, outra pessoa morrerá. "Pra mim, se eu ficar grávida, de novo, outra pessoa já está indo".

"M: Eu não sei se eu sou mãe, eu nåo sei se levo aquele jeito de mãe. Eu brinco com as minhas filhas, eu dou as coisas pra elas, eu brigo com a minha filha mais velha, mas eu năo sei. Eu me sinto 
particularmente bem diferente. Acho que mãe tem que ser mais carinhosa, né? Acho que eu não sou não. Não é questão de dizer que eu fico batendo, năo. Eu brigo. Eu não sei o que é ser mãe, o que é máe...

E: E estar grávida, como é estar grávida?

M: Eu năo sei. É uma sensação gostosa, é bom sentir, né? O nené dentro da gente, mexendo, aquela coisa toda, aquela preparaçăo maternal, mas o que é difficil é a criaçăo, criar filho sozinha, jovem e ainda aparece um monte de coisa na sua vida" (p. 19).

Márcia não quer ter mais filhos, mas essa decisão nada tem a ver com o HIV, pois, para ela, a gravidez de uma mulher soropositiva não difere da de uma mulher soronegativa e se, eventualmente, o bebê vier a nascer com o virus, não haveria nenhum problema. Ela não quer mais filhos, por acreditar que, quando alguém nasce, inevitavelmente, alguém de quem ela gosta, irá falecer. Ela associou nascimento com a idéia de morte ou perda.

\begin{abstract}
"Mas o fato de vocé já ter uma filha de dez anos, uma filha de seis meses, vocé quer ter outros filhos?

M: Năo, eu não quero năo. Năo por ser HIV porque năo tem nada a ver, năo! Eu năo sei, mas eu acho que se eu tiver um outro filho vai acontecer outra coisa na minha vida.

E: Outra coisa boa?

M: Ruim, ruim!

$E: E$ ai ficou associado a idéia de filho com catástrofe?

M: Com morte. Com a morte, com perda. Pra mim está assim agora.

E: Deixa eu ver se eu entendi. Vem uma vida e a morte está al?

M: Vem uma e leva outra. Pra mim é assim. Do nascimento da minha filha mais velha, com tres meses de vida, a minha filha tinha, a minha máe morre. No nascimento da minha segunda, com cinco meses de gravidez o pai morre. Entåo chega de filho, entåo eu fiquei, coloquei aquilo na minha cabeça" (p. 18).
\end{abstract}

Quanto ao relacionamento com as filhas, Márcia acredita que ela deve contar, pessoalmente, sobre o fato de que ela é soropositiva, e isso não deve influir na relação entre elas. Ela acredita que vai receber apoio e reconhecimento, por parte das filhas. "Ah, eu acho que eu vou merecer 0 amor da minha filha" (p. 23).

Ao final da entrevista, Márcia faz um comentário, que parece apontar para o momento dificil, que vive.

"E: Tem alguma coisa que voce gostaria de acrescentar, de dizer de sugerir? Fique à vontade.

M: Viver a vida e ser feliz porque tudo nela, vocés tém. (pausa).

Saudade, palavra triste, quando se perde um grande amor..." (p. 25)

A entrevista de Márcia evidencia os problemas de uma série de relacionamentos fortuitos ou, mesmo, violentos. Na maioria das vezes, ela ficou sozinha, encarregada dos cuidados das filhas. O companheiro, que ela apontou como "o amor de sua vida", ajudou-a um pouco, mas logo foi preso, e só foi solto para "morrer em casa". Sua própria mãe faleceu, quando ela tinha apenas 14 anos, e acabado de ter uma filha. 
A maternidade aparece como uma questão: o que é ser mãe? Márcia afirma não saber, mas, por outro lado, ela aponta que suas filhas são sua "razão de viver", e que amamentar é o "prazer de ser mãe". Sua primeira gravidez aconteceu durante a adolescência e, para ela, não foi possivel significar a questão da maternidade, naquele momento. Na segunda gravidez, embora já tivessem ocorrido várias situações difíceis em sua vida, houve outras perdas. Ela afirmou "estou traumatizada com filho", pois quando ela pensa em sua gravidez, logo lembra de alguém que morreu. A associação nascimento/morte ficou muito marcada, um trauma.

Márcia contou que engravidou, novamente, porque "queria um filho para que sua filha tivesse companhia" e, nesse sentido, vemos uma desresponsabilização de sua parte, quanto a essa questão: não é para ela, é para - outro. Ela suspeitava de que seu companheiro poderia ter "alguma doença" e, ainda assim, ela se arriscou a engravidar. Quando ela engravidou, pela segunda vez, e recebeu a noticia do HIV, ficou desesperada. Mas recebeu apoio e orientação da equipe multidisciplinar, o que parece ter ajudado a conter suas angústias, durante a gravidez.

Márcia contou uma fantasia, a respeito de "seus maridos": eles estariam brigando por ela, no céu, e ela precisa acender duas velas, na igreja, para evitar maiores disputas. Podemos acrescentar à sua fala "eu e meus maridos (mortos?)". Quem é Márcia, então? Uma viúva, uma mulher seguidamente marcada pela morte e, nesse sentido, o HIV é apenas um de seus problemas. Com tanto sofrimento, Márcia passou a beber. Parece fazer sentido que ela tenha tido dificuldades para suportar tanto sofrimento e passado a apresentar o uso abusivo de bebidas alcoólicas, como um sintoma.

A história de Márcia nos remete a uma série de excessos. Durante sua entrevista, ela ria copiosamente, chegando a gargalhar. Quem escuta, não pode deixar de ouvir esse excesso. Ela disse que "chorou por dentro". Mas ela argumentou: "o que fazer? Rir para não chorar".

Quanto ao relacionamento com sua filha, percebemos mais um ponto interessante "eu vou merecer o amor da minha filha". Por que ela não merece ainda? É possivel abordar a história de Márcia, pela tentativa de um sujeito lidar com as perdas. Eis o trauma. $O$ que não podemos deixar de apontar é que ela associa o trauma com o nascimento de um filho. Como sujeito, Márcia não parece responsabilizar-se por suas decisões, mas, sem dúvida, é ela quem paga um alto preço por isso. Como alguém que sabe de suas limitações, ela se pergunta: será que minha filha vai me amar? Será que sou merecedora desse amor? Lembremos que ela é, efetivamente, "uma mãe que não se sente mãe".

Seu comentário final, também, é digno de nota: como um conselho para o outro, ela diz "viva feliz, pois você possui tudo o que precisa", quanto a mim, só me resta a "saudade, palavra triste, quando se perde um grande amor". É desse "resto", desse "excesso" que se trata, quando se trata um sujeito, por meio da psicanálise. 


\section{2 - A construção do sentido das falas das mulheres: entre semelhanças e diversidades.}

A leitura das entrevistas possibilitou a descoberta de vários pontos em comum, bem como diferenças singulares nas histórias de cada entrevistada. Neste trabalho, procuramos centrar nossa atenção na busca dos aspectos mais diretamente relacionados com as decisões reprodutivas das mulheres vivendo com HIVIAids. Com intuito de facilitar o acesso do leitor aos temas, que consideramos mais relevantes, optamos por destacar as seguintes categorias:

\section{1 - A função da gravidez.}

\section{1 - A gravidez como causa de mudanças positivas na vida.}

Para algumas entrevistadas, a gravidez constituiu uma oportunidade impar de superar a marginalidade (deixar de usar drogas ou deixar de se prostituir) e retomar uma vida produtiva. Além disso, em função da gravidez, houve incremento do suporte familiar, social e institucional, recuperação da saúde; sentimento de completude e beleza, possibilidade de retomar seu relacionamento com o pai da criança, entre outros.

No caso de Miriam, as mudanças foram evidentes, pois ela não só deixou de se prostituir e usar drogas, mas também, por ser soropositiva e estar grávida, teve acesso a suportes institucionais, que the permitiram mudança de profissão, uma retomada de cuidados com sua própria saúde e a possibilidade de ficar com seu filho. Miriam deixou claro que não pretendia ficar com seu filho, mas quando ele nasceu, "apegou-se a ele". Ela já tinha deixado sua primeira filha aos cuidados de uma irmã e, agora, a decisão de ficar com esse filho era algo que dependia da possibilidade logística de cuidar do mesmo (ter um emprego e onde morar).

"M: O fato de eu ser usuária (de drogas), bebia, muitas noites mal dormidas, - fato também poderia indicar uma criança com deficiência. Poderia trazer sérias consequências para ele. Entăo, a minha preocupaçăo era mais a criança" (p. 4).

"Mas, hoje, criando para o meu filho, é a coisa mais maravilhosa, porque foi através dele que eu estou aqui. Se não fosse o meu filho, eu poderia estar morta ou presa. Ou eu não sei o que poderia, ou poderia estar por aí, como uma indigente pelas ruas, pelo fato das drogas. Então foi através dele que eu estou aqui. Eu me cuido e perdi muitas coisas. E hoje eu tenho um relacionamento também.

E: Vocé acha que o teu filho foi um estímulo pra viver? Pra enfrentar o HIV e se cuidar? O fato de você ter ficado grávida foi um impulso que te mobilizou para a vida, para mudar a tua vida? Você acha?

$M$ : Eu acredito que sim. Năo foi uma coisa planejada e eu cheguei a ter o dinheiro pra mim poder fazer o aborto, mas não fiz e, na hora certa, eu procurei ajuda e tive todo apoio. Não só eu, como ele.

E: Esse apoio também foi fundamental, né? 


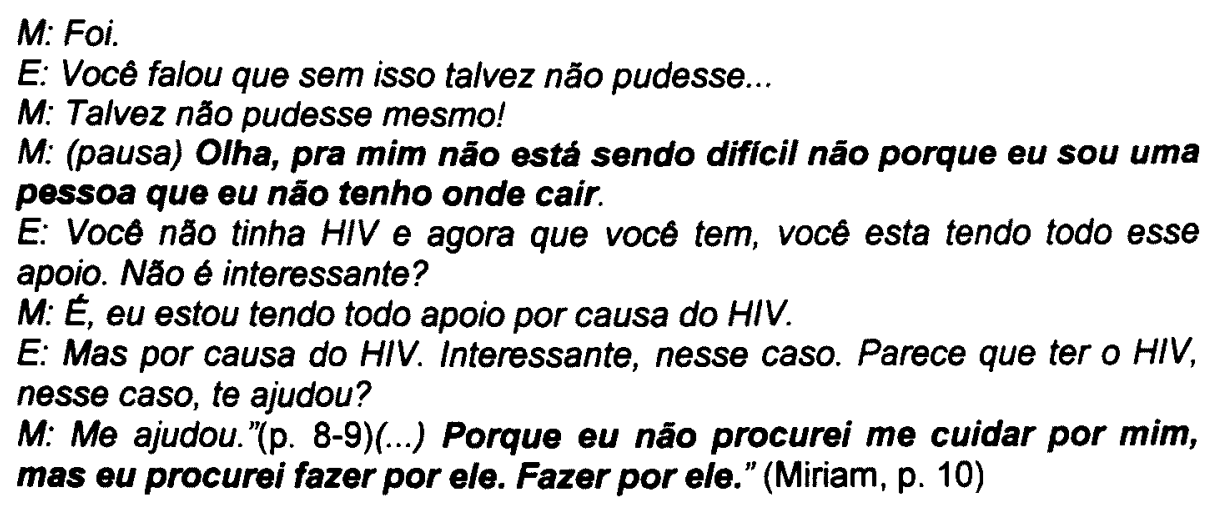

Sílvia, também, relatou uma mudança radical em sua vida a partir da gravidez. Antes de engravidar, não via nenhum sentido em se tratar (do HIV), ou mesmo, manter laços significativos com sua família. Ela planeja ter outros filhos, preferencialmente, um menino. Embora Silvia não assuma uma posição de responsabilização sobre a decisão de "se deixar engravidar", fica evidente, através de seu relato, que a experiência da gravidez constitui uma mudança, que possibilita que ela cuide si, através do cuidado do outro, pois ela afirmou que, ao nascer sua filha, nasceu também uma nova Silvia.

"E: E como é para vocé essa experiencia de ter um filho?

S: Ah, maravilhosa. (risos). Sei lá. Minha filha é tudo pra mim.

E: Sua filha é tudo pra vocé.

S: Se eu vivo mesmo é por causa dela porque senão eu acho que eu náo tava nem ai com a vida."

(...)

E: Te emociona isso, năo é...E ser măe, como que é ser máe?

S: Tipo muda, né? Tipo muda tudo porque fica mais responsável. Uma coisa que você não faria nunca, agora faz. Tipo, eu saía muito, agora náo saio. Tudo que eu faço é para minha filha. É bem diferente. Quando vocé é máe, tudo muda."

(...)

"E: Vocé acha que junto com esse bebé que nasceu, nasceu também uma nova Silvia?

S: Nasceu. "(Silvia)

A entrevista de Maria mostrou problemas na satisfação de necessidades básicas. Ela afirmou "que é que eu tenho a perder?" evidenciando que, na verdade, nada possui. $O$ fato de ser soropositiva $e$ mãe the garantiu o acesso a benefícios, que ela não teria condiçōes de conseguir por conta própria e, além disso, a gravidez lhe garante proteção em relação à violência doméstica.

"Eu acho que estou grávida. E o policial falou, então deixa, não pode tirar o raio $x$. E o que vai fazer com o homem aí? Vai dar queixa, vai $B O$ contra ele? Eu disse que vou fazer não, porque ele é o pai do meu filho, como vou fazer? Ai eu me mudei pra casa da minha tia de novo, fui embora. Ele lo companheiro) foi atrás de mim, falou que nunca mais ia me bater, fez carinho e, desse dia em diante, nunca mais me bateu. $A$ única coisa que ele faz é carinho" (Maria, p.9). 
Quanto a esse aspecto, Barbosa (1999) já havia observado que a sexualidade e a maternidade poderiam ser utilizados como instrumento de comunicação e meio de troca de necessidades e desejos. Knauth (1999) vem reforçar essa observação, ao relatar que as mulheres soropositivas passam a contar com novos "recursos", como reaproximação familiar, contatos com ONGs e retomada de capacidade reprodutiva. Tanto Santos (2002), quanto Sowell e col. (2002), referem que fatores ligados a circunstâncias de vida, bem como fatores psicossociais (desejo de ser amada ou aceita) têm grande influência na decisão de ter filhos entre mulheres vivendo com HIVIAids. Nesse sentido, nossos achados corroboram com o observado na literatura sobre 0 assunto, mas o destaque que trazemos para essa questão, refere-se à sua expressiva evidenciação em várias entrevistas, o que pode apontar que a condição da gravidez, na população estudada, pode apresentar-se como um fator significativo para seu resgate social. Tanto Campos (1998), quanto Knauth (1999) apontam que o status de mãe pode restaurar a identidade social dessas mulheres, e a maternidade pode configurar-se como um desafio perante a doença e uma retomada da condição de "normalidade".

No que concerne às vantagens de ser soropositivo, o trabalho de Abadia-Barrero (2002) mostrou que, embora seja possivel reconhecer diferentes situaçōes, quanto ao acesso às terapias anti-retrovirais ou suportes institucionais, o quadro brasileiro traz alguns benefícios, que não são facilmente encontrados em outros cenários no mundo.

\section{2 - A gravidez e filhos, como estímulo para se cuidar e viver.}

Algumas entrevistadas deixaram claro que seus filhos constituem um estímulo para sua vida, para que se tratem e sobrevivam ao HIV. Nesse sentido, a fala de Cátia é contundente:

“C: E eu năo queria ver eles (os bebés)!

E: Por que?

C: Eu nåo queria! Porque eu estava assim, ai meu Deus, eu não quero ver eles. Se eu ver eles, depois vão tirar de mim. Deus me deu um desses para mim ter mais vontade de viver e viver por eles. Porque eu vivo por eles."

"C: Ter um filho, eu acho que é uma oportunidade de dar muito amor pro teu filho. Precisamente no meu caso, ensinar ele o pouco de vida que resta, né? Passar para ele um pouco de segurança porque se vocé faltar, já vai deixar o seu filho preparado, dar muito amor, ensinar coisas boas. Isso eu tenho que fazer para os meus, né? Eu falo para eles que eu náo vou estar toda vida pertinho deles e que talvez vai ser... venha rápido. Talvez vai demorar muito tempo para o pai do céu me chamar." (Cátia)

Eliana lembra que ser mãe e soropositiva implica um desafio perante a vida, uma luta ainda mais acirrada. "(mãe soropositiva) tem que ser guerreira, né? Acho que duas vezes. Tem que ser mais..." 
A pesquisa de Santos (2002), bem como os trabalhos de Campos (1998) e Knauth (1999), indicam a existência de uma associação positiva entre pensar em ter filhos e ter motivação para lutar pela vida, e que a maioria das mulheres soropositivas referem que seus filhos são o principal motivo que as mantém lutando pela vida e empenhadas em seu tratamento. Os dados deste trabalho permitem concordar com esses autores, pois foi possivel perceber, através do relato das entrevistadas, que estar grávida configura uma bênção e um desafio perante a doença, o que as incita a lutar, ainda, por sua sobrevivência.

\section{3 - A busca de um novo sentido para a gravidez: ter propiciado} a possibilidade do diagnóstico do HIV na mãe.

Ana Carolina procurou elaborar o diagnóstico de HIV, durante a gravidez, dando um outro sentido para a situação: para ela, foi "graças à gravidez que ela pode descobrir o HIV". Ela colocou que seu filho "não pediu para nascer", portanto, não é "culpa dele", e, nesse sentido, parece haver uma elaboração consciente para a questão. Esse aspecto ilustra que 0 sujeito, diante de uma situação que remete para a questão da castração, procura valer-se de mecanismos de defesa, para garantir a manutenção de sua integridade egóica (FREUD 1996e).

1.4 - O filho, como "intruso", que revela o segredo, que é a condição de soropositivos da mãe ou do casal.

No discurso de Flávia, foi possivel identificar o estranhamento da descoberta recente da gravidez, mas sua grande preocupação é que sua gravidez possa vir a revelar, para sua familia, o segredo sobre a condição do casal, como portadores do HIV. Ela fantasia que alguém da equipe médica, na hora do parto, vá revelar que tanto ela, quanto seu marido, são soropositivos. Nesse sentido, o "filho-intruso" poderia revelar o segredo do HIV e mudar a situação social do casal.

"E:O que é para vocé ter um filho?

F: É uma coisa estranha. (risos). Porque eu ainda não me adaptei não! $E$ uma coisa de intruso, porque eu ainda năo me adaptei năo. "(Flávia)

Podemos interpretar essa fantasia, como a colocação do filho como um objeto que pode ser "modelado, determinado, escolhido". Parece haver uma tentativa de controle da situação que, na verdade, denuncia o descontrole que o casal enfrenta em face do fato inexorável de serem soropositivos. Parece que o filho só pode ser incluído nessa familia como uma expressão da superação do HIV, caso contrário, corre o risco de ser alvo da projeção familiar e tornar-se o "intruso", que denuncia a Falta do casal.

1.5 - Gerar um filho perfeito (soronegativo): reabilitação narcísica. 
Barbosa e Villela (1996) apontaram que a maternidade adquire um sentido de reasseguramento narcísico. Consideramos esse aspecto fundamental para a compreensão da função da gravidez e maternidade em mulheres vivendo com HIVIAids, pois, entre nossos achados, ficou evidenciado que o impacto do diagnóstico de HIV atinge, diretamente, a condição narcísica do sujeito e, tanto a gravidez, quanto a maternidade, parecem configurar-se como uma reabilitação da condição narcisica, gerando a "superação do HIV".

Observamos, por exemplo, que a grande preocupação de Ana Carolina, após o diagnóstico de HIV, era o medo de que seu filho nascesse "defeituoso", assim como Débora, que deixou claro que "Minha preocupaçăo maior era essa, dele nascer positivo (para HIV) e defeituoso."). Podemos observar, através dessas falas, que a função do filho (sua relação com o filho) se processa a partir de uma identificação imaginária. Um filho "defeituoso" seria ○ "resultado" de uma "mãe defeituosa", o que põe em questão o HIV. Um filho "saudável e perfeito" garantiria a "superação" do HIV, podendo apontar para um resgate narcísico da mãe.

Quando o "resultado" é favorável, ou seja, quando o filho é soronegativo, ele é imediatamente colocado na condição de filho "perfeito" e pode assumir, enfim, um lugar muito especial em relação ao desejo da mãe: "No meu caso, filho é o sentido da minha vida. É o que faltava para mim. Realmente é o que faltava, né?", como ressalta Débora. O filho assume, então, a função de "completar" a mãe, de tamponar uma Falta, o que, em termos freudianos, remete à inveja do pênis (FREUD 1996g). Mas, a completude, supostamente narcísica da díade mãe-bebê, não é a expressão maior do feminino, pelo contrário. $O$ que se observa nesse processo de "tornar-se mãe", como ela mesma aponta, é uma tentativa de lidar com a impossibilidade de ser completa (PRATES 2001; ANDRE 1987). Nesse sentido, o que Débora visa, com sua gravidez, é uma tentativa de se fazer completa, remetendo-a a um gozo fálico.

O discurso de Cátia sugere esse lugar especial que os filhos ocupam no desejo da mãe soropositiva. Parece que, se o filho é o que ela "precisava", ou algo que a completa, enquanto o HIV é algo de "descompleta". Ter gêmeos, após o diagnóstico de HIV, e ter tido um filho soropositivo, constitui uma oportunidade, em suas palavras: "Ter um filho, eu acho que é uma oportunidade de dar muito amor pro teu filho. Precisamente no meu caso, ensinar ele o pouco de vida que resta, né? Passar para ele um pouco de segurança, porque, se você faltar, já vai deixar o seu filho preparado, dar muito amor, ensinar coisas boas". Parece que a oportunidade está, justamente, no fato de que seus filhos constituem uma superação da pobreza, da fome, do abandono do marido e, finalmente, da doença (HIV).

O filho, como resultante de uma superação do HIV, é algo que, também, podemos observar no relato de Celina, que diz ter conseguido o 
seu "filho-troféu". A superação do HIV fica caracterizada, pelo fato de que seu filho não nasceu com o virus.

"O fato de ele (o filho) estar bem (năo ter nascido com HIV), melhor ainda. Um troféu"(Celina, p. 20).

O lugar que o filho ocupa no desejo da mãe é anterior ao seu engendramento, propriamente dito, e isso se evidencia no relato de Flávia, que não deixa dúvidas de que, se por um lado, o fato de ser soropositiva teve grande influência na sua decisão de não ter um filho, por outro lado, năo a impediu de correr o risco de engravidar. Entretanto, mediante a possibilidade de alto risco de infecção do filho, ela não relutaria em interromper a gravidez. O casal só se permite "produzir algo perfeito e saudável", caso contrário, rejeitam sua "produção".

\section{2- Des-responsabilização do sujeito pela decisão de ter um filho.}

\section{1- Responsabilização de um outro (marido, filho, família).}

O trabalho de Sowell e col. (2002) revela que as decisões reprodutivas das mulheres vivendo com HIVIAids são fortemente influenciadas pela relação com 0 parceiro, fatores psicossociais (necessidade de ser amada), crenças religiosas, tendência à adoção de tradicionais papéis de gênero (ser mulher implicaria em ter filhos), entre outros.

Sob o ponto de vista fenomenológico, observamos, através do discurso de mulheres soropositivas, que suas decisões reprodutivas visam uma resposta do sujeito, em relação ao outro, pois elas relatam que a decisão de ter um filho ocorreu, fundamentalmente, para satisfazer ao outro, ou, ainda, para justificar seu papel social "como mulheres".

Contudo, podemos nos valer da teoria psicanalítica lacaniana, para observar qual o posicionamento lógico (ZIZEK 1992) que o sujeito adota para estruturar o desejo inconsciente, envolvido nas decisões reprodutivas. Vimos que Débora referiu "uma vontadezinha" de ter um filho, mas a decisão foi de seu marido. Suas familias também "cobravam" que eles tivessem filhos e coube a ela, então, o ato de concordar e de se fazer objeto de desejo do Outro/outro. Tal situação parece indicar que Débora não pôde ou não pode se responsabilizar pelo próprio desejo, e encontrou uma estratégia para contornar essa questão: ela deseja o desejo do outro. Trata-se de uma posição histérica. Sabemos que toda estratégia, que visa a uma barganha com o desejo, vai fazer com que o Real se presentifique. O sujeito constrói uma narrativa imaginária para tentar explicar sua conduta ou sua história, mas a angústia, que não pode ser tamponada com arranjos, como estes, muitas vezes, retorna sob a forma de sintomas. 
No caso de Débora, ela afirmou que ficou ainda mais sensivel, procurando brigas, culpando seu companheiro, como se não tivesse nada a ver com a decisão de ter um filho. Ela se colocou no lugar de vítima da situação, incapaz de assumir qualquer responsabilidade pelo seu desejo, e se sacrificou para atender ao desejo do companheiro, oferecendo-lhe seu corpo para gerar um filho. Esse apanágio de sofrimento parece caracterizar a maternidade, mas o que se conquista, a partir dessa posição, é um lugar especial em relação ao desejo do outro/Outro. Ela saiu da posição de faltosa (por ser soropositiva) e tornou-se credora.
"D: Eu achava que se engravidasse o bebê já era..."
"E: como é que foi a sua decisão de ter um bebé?
D: Náo foi minha. Ele sempre quis.
E: Ele também era portador?
$D$ : É. Eu nunca quis pelo medo disso. Assim que caisse o esperma dele lá dentro de mim, meu bebezinho já tava infectado. Eu tinha isso na cabeça. Nunca me preocupei em ficar me informando sobre gravidez, nem sonhava em ser måe, por causa do HIV. Eu achava que ele já ia ser automático HIV, entăo eu năo queria, mas ele queria de todo jeito e ele falava "nåo, vamos ter um bebe!" A gente tem que ter, a gente cuida, do jeito que ele nascer a gente aceita e a gente cuida, vamos de todo jeito. Mas o meu medo era esse.
E: Ainda assim ele queria?
D: Queria, o sonho dele era ser pai. No fundo, no fundo, eu queria ser máe, porque eu tinha inveja das minhas colegas, da minha irmá. No fundo, no fundo, eu tinha uma vontadezinha, mas tinha medo.
$E$ : $E$ vocé acha que o psicológico vem da onde, esse primeiro abalo, do fato de se saber grávida e ser soropositiva?
$D:$ Por estar portando um inocente dentro de vocé e que está dependendo de vocé para vir ao mundo bem ou náo" (Débora).

\section{2 - Configuram a gravidez como um "acidente" ou "descuido".}

Tanto Flávia, quanto Eliana, caracterizam suas gravidezes como um "descuido", sendo que ambas admitem que, mesmo sabendo-se soropositivas, não usaram nenhum contraceptivo, de forma consistente. Há uma contradição entre discurso (o falar) e comportamento (o agir), pois embora tenham conhecimento dos riscos de engravidar e de infecção cruzada, não parece haver mudança na forma como o casal se relaciona sexualmente.

"E: (...)Como foi sua decisăo de ter o bebe??

(...) F: Quando era antes do meu marido descobrir que era soropositivo a gente tenha relação sem. Agora estou tendo com preservativo, mas de vez em quando eu descuido. (risos). Foi que eu descuidei, que aconteceul $E:$ O que voce acha que acontece quando descuida? O que tem a ver? F: Descuido é vocé não usar nada. Saber que vocé tem essa doença e decidir nåo usar. É que, às vezes, machuca e eu falei, deixa sem" (Flávia).

"E: (...) E da terceira filha vocé sentiu que as pessoas poderiam pensar "ah, mas ela já tinha o HIV e teve outra...". Tipo "nossa, que irresponsabilidade"? E: Senti. Por que a Hebe veio assim, foi um descuido meu, eu náo queria.

E: Como assim, um descuido? 


\begin{abstract}
E: Porque a camisinha, até algumas semanas atrás, eu usava camisinha de uma forma que não era correta. Então, foi um descuido, eu nāo planejei ter ela, entendeu? Para mim, eu vejo como um descuido"(Eliana)
\end{abstract}

A posição de Eliana, quando diferencia as três gestações, parece constituir uma busca de "justificativa" para ○ Outro, o que, em última instância, não deixa de ser uma justificativa para si mesma: na primeira gravidez ela era "muito nova"; a segunda foi "planejada" e ela queria um menino e, finalmente, a terceira gravidez, foi um "descuido". Eliana refere que se sente culpada, em relação à segunda filha, a gravidez planejada, talvez, porque foi, justamente, naquela gravidez, que ela gerou um bebé soropositivo. A terceira gravidez foi "um descuido" e não parece despertar culpa, à medida que a terceira filha foi "salva". A culpa relaciona-se, diretamente, com o fato de que sua filha tem o HIV, e não, pelo fato de que ela decidiu ter um filho.

O relato de Cátia é notável, pela mudança de versões: o "acidente" da última gravidez, foi com o uso de preservativo, ou não? O que nos interessa é perguntar o motivo que a leva ter que "criar" tais versōes. Cátia contou a segunda versão "sussurrando", o que nos faz pensar que alguém não pode ouvir essa nova versão. Que outro ou Outro não pode escutar? Não vamos deixar de considerar que, atualmente, as mulheres que participam de grupos de apoio são "orientadas" a comportarem-se "corretamente", usando preservativo em todas as relações, inclusive, estando grávidas, com intuito de evitar o risco de infecção cruzada. Se, antes eram criticadas por terem contraído o virus, por "terem sido moças que não se comportaram", agora, parecem ser alvo de críticas por não obedecerem às orientaçōes da equipe de saúde (OLIVEIRA 2002, apud PAIVA e col. 2002).

\title{
3- Produções sintomáticas e mecanismos de defesa.
}

\section{1- Sintomas.}

Podemos afirmar que os sintomas que os pacientes "produzem" chamam a atenção da equipe de saúde, na maioria das vezes. Isso ocorre, não apenas em função do estranhamento que esses sintomas costumam engendrar, mas, também, porque muitas vezes os próprios sintomas constituem elementos que trazem desconforto, ou desorganizam o sistema com os quais os pacientes são recebidos ou atendidos.

Tanto Cátia, quanto Celina, apontaram reações "estranhas" no pósparto. Elas tiveram reaçōes emocionais muito intensas, logo que seus filhos nasceram, e conseguiram perceber que sua intensa angústia se relacionava com um medo "irracional" de que alguém iria lhes tomar o(s) filho(s). $O$ fato de que estavam separadas de seus filhos, enquanto outras mães estavam em alojamento conjunto, constituiu, também, um outro elemento gerador de ansiedade. Embora, sob o ponto de vista racional, tenham compreendido e concordado que seus filhos estavam sendo "bem cuidados", sob o ponto de 
vista emocional, houve a emergência de grande angústia, que culminou nos intensos sintomas de ansiedade e choro, o que gerou necessidade de atenção especial, por parte da equipe e/ou da familia.

Cátia sentiu medo de dormir, e identificou esse medo com o medo de morrer e de que alguém fosse tomar seus filhos. Diante da situação do parto, da iminência do corte preciso em seu corpo (cesárea), e da separação entre ela e sua produção (bebês), temos a formação de um sintoma, que nos leva a pensar que há um sujeito deparando-se com sua Falta e com a angústia ali imbricada. É evidente que podemos avaliar seus medos como "normais", considerando-se a situação, mas ela mesma apontou que havia um estranhamento, comparando com o que ela havia sentido nas gravidezes anteriores. Na sua última gravidez havia, portanto, algo diferente. Parece que o HIV re-edita uma questão anterior: a evidenciação da castração simbólica, agora atualizada no Real do corte, que a intervenção cirúrgica aponta.

\begin{abstract}
C: Que não tinha mais sentido! Porque eu ouvia, passava na televisão, e eu assim falava: "nossa eu contaminei meu proprio filho!", eu ficava em paranóia, sabe?". A quarta gravidez é uma historia, "um acidente" em duas versőes. Na primeira entrevista ela contou que o marido alcoolizado, depois de quatro anos sem nenhum contato sexual, a procurou e ela pediu que ele usasse preservativo, o qual estourou. Na segunda entrevista, ela contou, sussurrando que, na verdade, não havia usado preservativo, e que seu marido tinha "feito em cima dela". C: É... assim, morrer, né? Não me deixa dormir, porque, se eu dormir, eu năo vou voltar. Aquele sem sentido."

"C: $E$ eu náo queria ver eles (os bebês)!

E: Por que?

C: Eu nåo queria! Porque eu estava assim, ai meu Deus, eu não quero ver eles. Se eu ver eles, depois váo tirar de mim. Deus me deu um desses para mim ter mais vontade de viver e viver por eles. Porque eu vivo por eles" (Cátia).
\end{abstract}

Celina chorava copiosamente e telefonava para sua familia, gerando grande apreensão neles e na equipe que a atendia. Ela relatou uma série de "medos": medo de perder novamente o marido, medo de que seus dois filhos ficassem órfãos de pai, medo de que ela viesse a morrer, antes mesmo de dar à luz (o que inclui o medo de que seu filho venha a morrer também) e medo de que alguém venha tomar ser filho (no pós-parto). Os sintomas parecem responder ao registro de suas perdas, exortando uma punição. Em seu discurso, ela parece assumir, tanto a posição de algoz, quanto de vítima.

O relato de Débora é interessante, por mostrar que, muitas vezes, o sintoma responde de forma egossintônica, ou seja, atendendo a uma demanda de manutenção do narcisismo do sujeito. Apesar de ter leite, antes de o bebê nascer (o que é relativamente comum), assim que foi realizada a cesárea, seu leite secou. O corpo, enquanto representante do desejo, pode expressar aquilo que não pode ser dito. Nesse caso, o que se produziu foi um sintoma (o leite secou), que justificava a impossibilidade de amamentar. 
Por um mecanismo de inibição, o sintoma visou a contornar a angústia implicada.

Rodrigues (2000) comenta que a fantasia é uma das formas fundamentais que o ser humano criou para tentar lidar com a dor, sendo, ao mesmo tempo, uma criação com aspectos coletivos (inserida no código da cultura humana), como, também, possui uma dimensão absolutamente particular, onde cabe ao sujeito a construção de uma realidade capaz de atenuar a dor de ser inteiramente só diante da morte inexorável. O relato de Márcia, sobre sua fantasia a respeito de "seus maridos" (que eles estariam brigando por ela no céu, e ela precisa acender duas velas na igreja par evitar maiores disputas) é interessante, por explicitar que a fantasia tem a função de proteger o sujeito da angústia. Podemos acrescentar que Márcia assumiu a identidade de uma mulher seguidamente marcada pela morte e, nesse sentido, o HIV é apenas um de seus problemas. Parece fazer sentido que ela tenha tido dificuldades para suportar tanto sofrimento e passado a apresentar o uso abusivo de bebidas alcoólicas, como um sintoma.

\section{2 - Culpa.}

A culpa constitui um fenômeno bastante comum no relato das entrevistadas. Knauth (1999) assinala que as mulheres soropositivas têm necessidade de manter uma "vida normal", procurando "esquecer do HIV". A manutenção de tal "normalidade" parece relacionar-se com sua necessidade de mascarar sentimentos de ambigüidade, angústia, hostilidade, raiva, depressão e medo, que poderiam ser interpretados como manifestação de culpa e, por isso, são vistos como uma espécie de "futilidade perigosa".

Entretanto, podemos observar nuances que relativizam a função, incidência e justificativa do sentimento de culpa entre as entrevistadas.. Rita afirmou que a primeira gravidez foi "desejada" $e$, quanto a isso, não se sente "culpada", entretanto, a segunda gravidez foi um "acidente", que gerou culpa. Podemos nos perguntar o por quê da culpa, considerando que a responsabilidade, por um "acidente", não é algo que, sob o ponto de vista da consciência, possa gerar a responsabilização do sujeito. Mas, o uso esporádico de preservativo masculino pode indicar que há um pacto silencioso, que gera conseqüências. Embora Rita tenha declarado se sentir culpada, ela não parece se responsabilizar por suas escolhas, não sendo capaz de se responsabilizar pelo que lhe é inexorável, ou seja, seu Inconsciente.

No caso das entrevistadas, que tiveram filhos soropositivos, a culpa parece relacionar-se, diretamente, com o status sorológico do filho e, não, com o desejo de engravidar. Eliana sente-se culpada por ter planejado a gravidez, que gerou sua filha soropositiva. Por sua vez, Cátia sente-se culpada por seu filho ter nascido com HIV e, embora ela tenha afirmado que desconhecia seu status sorológico e que a gravidez não tinha sido planejada, a culpa parece responder a um imperativo superegóico. Sob o 
ponto de vista do Inconsciente, a lei é outra: o sujeito tem que se responsabilizar por aquilo que ele não pode escolher, ou seja, que é submetido à castração.

No caso de Mariana, a culpa relaciona-se com a perda de seu filho, bem como de seu marido. Ela supõe que deveria, ou poderia, ter feito algo para impedir tais perdas, e a culpa assumiu, aqui, o status de uma cobrança, que resulta na adoção de um comportamento sintomático: não se envolver afetivamente com outra pessoa, para não correr o risco de perder novamente.

No caso de Débora, a culpa se relacionava com o medo de que o filho "produzido" fosse "imperfeito" (o fato de ele ser soropositivo ou possuir algum defeito físico). Ela fez todos os exames e dedicou-se, intensamente, ao seu projeto de produzir um rebento "perfeito". Durante os exames de ultra-som, Débora temia descobrir que seu filho tinha alguma mal-formação e relacionou esse temor com uma "culpa" ou um "peso" inesgotável, que parece constituir uma resposta, por fazer valer um desejo que ela considerava interdito.

\section{4 - O HIV é um segredo.}

Mulheres soropositivas procuram estabelecer novas alianças, que possibilitem um melhor cuidado de si ou do companheiro, entretanto, parece haver um cuidado em manter a questão da Aids, como um "segredo bem guardado", e que só pode ser revelado em condiçōes muito especiais, ou que proporcionem algum tipo de vantagem, pois o medo da exposição social da sua condição sorológica é um fantasma que se impōe diariamente (KNAUTH 1999).

$\mathrm{Na}$ maioria das entrevistas, foi possivel perceber que a questão do HIV permanece como um segredo importante. Destacamos o relato de Flávia e de Ana Carolina. No caso de Flávia, a gravidez colocou em evidência essa questão, pois ela se perguntava como iria manter o segredo do HIV, caso algo, fora de seu controle, "a denunciasse". Ela relatou a fantasia de que alguém da equipe iria revelar o segredo, principalmente no momento da internação, para a realização do parto. Por sua vez, Ana Carolina colocou que, embora se sinta solitária, prefere manter o segredo, para evitar constrangimentos, pois supõe que será vitima de preconceito e retaliaçōes, por parte da sociedade e/ou empregadores.

\section{5 - Perspectivas de futuro.}

A reação diante da descoberta do HIV pode ser caracterizada por um "choque inicial", que interfere na própria identidade da mulher (CAMPOS 1998). As entrevistas possibilitaram a constatação de que as mulheres soropositivas elaboram mecanismos especificos para lidar com a questão do HIV, e isso implica conseqüências para sua vida e seu futuro. A história de 
Bianca ilustra a situação de uma mulher que procura criar uma forma de "viver com HIV" e, embora diga que ainda não morreu, sua atitude de "desapego" para com a filha é um mecanismo de defesa, que aponta para uma tentativa de preservar-se perante o inexorável, que é a morte. Em seu relato, temos a evidência de que, após o diagnóstico da infeç̧ão pelo HIV, a questão da vida e da morte assumiu um viés específico, ocorrendo uma perda de "pseudocertezas", que o neurótico assume para continuar vivendo, sem ter que se deparar com sua Falta constitutiva. Ela mesma o diz: "Depois de passar tudo que eu passei, eu fiquei o que eu me tomei".

"A minha menina, mesmo, eu fico pensando, ah, eu năo posso me apegar a ela. Ou ela se apegar a mim. E se eu morro? Ela vai sofrer.

E: E vocé também. Vocé năo sofre quando pensa assim?

B: (pausa). Viche! (se emocionou)" (Bianca, p. 14).

A mulher vivendo com HIV, que tem filho(s), provavelmente, terá que lidar com situações, como a incerteza de que o filho esteja efetivamente infectado; medo de que a mãe possa vir a transmitir o vírus no contato social, ou através dos cuidados cotidianos de higiene; dificuldades de compartilhar com outras pessoas sobre o HIV, por temer que a criança seja vitima de preconceito; medo de que percam sua condiçăo de assintomáticas e não possam cuidar efetivamente de seus filhos, entre outros (SANTOS 2002; KNAUTH 1999; CAMPOS 1998).

O relato de Cátia ilustrou que o medo da perda da condição de assintomática, ou o risco de adoecimento, que pode levar à morte, fez com que ela valorizasse cada momento com seus filhos, considerando-os "uma oportunidade". Ela procura se cuidar e ter esperança, mas seu horizonte de perspectivas é incerto, e a morte constitui sua única certeza. Nesse sentido, sua preocupação é garantir que seus filhos possam ser bem cuidados e não fiquem sem os cuidados necessários, caso ela venha a faltar.

"C: E eu năo queria ver eles (os bebés)!

E: Porque?

C: Eu năo queria! Porque eu estava assim, ai meu Deus, eu não quero ver eles. Se eu ver eles, depois vão tirar de mim. Deus me deu um desses para mim ter mais vontade de viver e viver por eles. Porque eu vivo por eles."

"C: Ter um filho, eu acho que é uma oportunidade de dar muito amor pro teu filho. Precisamente no meu caso, ensinar ele o pouco de vida que resta, né? Passar para ele um pouco de segurança porque se vocé faltar, já vai deixar o seu filho preparado, dar muito amor, ensinar coisas boas. Isso eu tenho que fazer para os meus, né? Eu falo para eles que eu năo vou estar toda vida pertinho deles e que talvez vai ser... venha rápido. Talvez vai demorar muito tempo para o pai do céu me chamar" (Cátia).

6 - Relações conjugais:

Alguns casais sorodiscordantes não usam preservativos, consistentemente, e afirmam que querem "compartilhar a condenação (HIV) por amor" (SANTOS e col. 2002). Observamos a idéia de que uma situação 
de risco poderia servir de "prova de amor" e, quando envolvidas emocionalmente, muitas vezes, as mulheres deixam de perceber comportamentos de risco, por parte de seu parceiro (como uso de drogas injetáveis), expondo-se ao risco de infecção ou de engravidar. (VENTURAFILIPE e col. 2000). BARBOSA E VILLELA (1996) assinalam que, para as mulheres, o amor adquire o sentido de abnegação, em função do desejo do outro. $\mathrm{Na}$ economia de trocas simbólicas, as mulheres adotam uma postura de "cumplicidade consentida", em relação ao suposto desejo masculino, num pacto de silêncio, no que diz respeito aos dilemas emocionais que o casal enfrenta (BARBOSA e VILLELA 1996; VENTURA-FILIPE e col. 2000).

Em várias entrevistas, foi possível evidenciar esse pacto de silêncio no casal, o que pode estar relacionado com questões de gênero. Celina contou que esse pacto de silêncio é algo que permeia a relação, antes mesmo da gravidez. Ela relatou que seu companheiro foi diagnosticado com várias doenças infecto-contagiosas (sexualmente transmissiveis), como sifilis, HIV e Hepatite C, mas o casal não adotou um comportamento de prevenção. Celina afirmou que prefere "ceder para não discutir", deixando de usar preservativos. Mas, ela mesma se contradiz, ao dizer que tem momentos em que quer se prevenir, e tem momentos que "não quer". Esse "querer e não querer", associado ao silêncio, como uma tentativa de "prova de amor", não deixa de gerar angústia para o sujeito.

"Eu tinha que estar mentindo sempre. Sempre. Eu tinha que estar mentindo sempre.

E: Vocé tinha medo do que?

C: Eu tinha medo de, por exemplo, de passar pro nené. De năo usar camisinha e passar pro nene.

E: De passar pro nené, por năo transar com camisinha?

C. É. Na gravidez. Porque pode passar. E tinha medo de falar para ele e tentar uma coisa pior. E desse aqui ficar sem pai também. Entáo, eu passei por esse trauma, e fui confiando. Mas foi dificil passar" (Celina).

Outro aspecto, que permeia a relação conjugal das entrevistadas, é o relato de uma série de vinculos afetivos fortuitos, que resultam, em muitos casos, em gravidezes indesejadas. Em várias entrevistas, observamos que mulheres são abandonadas e assumem, sozinhas, o cuidado dos filhos (relato de Márcia, Silvia, Ana Carolina, Miriam, Bianca, Eliana, Cátia). O relato de Maria e de Márcia diz respeito a relacionamentos permeados por violência doméstica. No caso de Maria, mediante uma gravidez, seu companheiro passa a tratá-la de forma menos violenta.

\section{7 - Relação com filhos:}

Silvia supõe que sua filha lhe será grata por ela ter assumido uma série de cuidados para evitar a TMI. Márcia, por sua vez, colocou que "eu vou merecer o amor da minha filha". Ela parece se questionar, como alguém que sabe de suas limitaçōes: será que minha filha vai me amar? Será que sou merecedora desse amor? Lembremos que ela é "uma mãe que não se sente mãe". No caso de mães que geraram filhos soropositivos, há o relato 
de culpa e arrependimento (como no caso de Eliana, Cátia e Mariana). Há, também, o receio de que as perspectivas de futuro não sejam favoráveis, em função da situação sorológica da mãe, pois elas temem que, se vierem a adoecer, seus filhos possam vir a passar dificuldades.

\section{8 - Relação com a equipe multidisciplinar}

Conforme abordamos na introdução deste trabalho (no capitulo I), alguns profissionais da área da saúde não informam às mulheres vivendo com HIVIAids sobre o baixo risco da TMI, por temerem que isto as encoraje a engravidarem. Essa sonegação de informações, por parte da equipe médica, tem conseqüências, em termos psicológicos, e, principalmente, no que concerne à Saúde Publica. Paiva e col. (2002) sugerem que existe um estigma anti-familia, associado a pessoas vivendo com HIVIAids, o que pode revelar uma violação dos direitos reprodutivos.

As entrevistas com Dia, Maria e Sílvia mostraram situações explícitas de preconceito, por parte da equipe de saúde, ilustrando que o medo e o preconceito, em relação às pessoas vivendo com HIVIAids, constitui algo que ainda acontece.

"Al ela (a enfermeira) virou pra mim e falou assim, "ah, vocé tenha certeza de que vai dar positivo". Eu falei, por que certeza? "porque todos dăo, impossivel". Ai eu já fiquei mal. Fiquei arrasada" (Dia, p. 6-7).

"S: (...) Em seis (enfermeiras) teve uma só que me tratou assim... sabe, eu me senti discriminada. Na hora de ter o bebé, tinha uma que tipo, năo gostava de pegar em mim, entendeu? Dava para ver...

E: A enfermeira?

S: E. Quando eu tive o bebe eu tava toda anestesiada, como que eu ia passar para a maca. Toda suja de sangue, mas năo dava. Eu tava morrendo de frio. Ela tava mandando eu passar para a maca! Ficava mandando. Ai eu falei assim: mas como é que vocé quer que eu passe? Eu năo consigo. Al que veio outra e que me ajudou. Ela falou "vocé não está vendo que ela está anestesiada e náo consegue passar?"

$E$ : Vocé sentiu que a outra enfermeira năo queria te tocar por causa do sangue. (ela assentiu). E vocé estava no quarto?

S: Năo eu tava passando para a maca no corredor" (Silvia).

"E: E por que vocé achava que não podia ter um filho?

M: é porque a médica falou que eu não posso ter um filho porque sou soropositiva. É muito arriscado vocé ter filho" (Maria).

Por outro lado, o relato de Sílvia, sobre a intervenção do médico que a atendeu na época do diagnóstico do HIV, mostrou que ele pretendia orientála a voltar para casa e "se comportar". Tal procedimento, apesar de bem intencionado, mostrou-se ineficaz, pois não tocou em seu ser, ficando como algo moralmente indicado. Sílvia não parece ter problemas em saber discernir, moralmente, o que é bom do que é ruim, e não parece que ela tenha a intenção de "magoar propositalmente" à mãe ou a qualquer outro. As pessoas diagnosticaram que ela fugia de casa "para chamar atenção", mas fugir de casa tem a função de permitir que ela mantenha sua parceria 
sintomática com as drogas. Essa parceria constitui um gozo, em "curtocircuito", que não passa pela ordem significante, e exclui qualquer intervenção de ordem moral-educativa.

Muitas vezes, a equipe de saúde assume o lugar de grande Outro para o sujeito. Quanto a esse aspecto, o relato de Cátia traz um fenômeno notável: sua mudança de versão da quarta gravidez. Cátia contou a segunda versão "sussurrando", o que nos faz pensar que alguém não pode ouvir essa nova versão. Que outro ou Outro não pode escutar? Não vamos deixar de considerar que, atualmente, as mulheres que participam de grupos de apoio são incitadas a comportarem-se corretamente, usando preservativo em todas as relações, inclusive, estando grávidas, com intuito de evitar o risco de infecção cruzada. Se, antes eram criticadas por terem contraído o vírus, por "terem sido moças que não se comportaram", agora parecem ser criticadas porque não obedeceram aos preceitos da equipe de saúde.

A entrevista com Maria permitiu que fosse possivel levantar algumas hipóteses sobre a relação que o sujeito estabelece com o grande Outro institucional. Embora seja fundamental o suporte institucional, isso, nem sempre, é algo fácil de ser realizado, na prática. Muitas vezes, o beneficiário invoca seus direitos e não consegue cumprir com os deveres que assume, ao ingressar no grupo, burlando as regras, ou distorcendo-as em seu favor. O caso de Maria aponta para o impasse da instituição, quando se depara com o sujeito que não "se conforma", pelo contrário, desafia e desacata a autoridade, assumindo uma posição de manipulação da piedade do outro.

Muitas pesquisas mostraram que o modelo de atendimento, centrado no médico, e a atenção voltada para o controle da infecção, mediante o uso de dispositivos tecnológicos, embora eficaz, do ponto de vista epidemiológico, desconsiderou as intersubjetidades envolvidas, pois houve a identificação de dificuldades no acolhimento das questões relacionadas à saúde reprodutiva (LANDRONI 2004; SANTOS e col. 2002; PAIVA e col. 2002). Nossos achados corroboram com essas pesquisas, uma vez que, em vários relatos, as entrevistadas referiram dificuldades na relação com a equipe multidisciplinar, entretanto, ressaltamos que, além da subjetividade, há outros aspectos a serem tomados em consideração, como o desejo inconsciente.

"Nós (equipe de saúde) fingimos que sua sexualidade e seu desejo (consciente ou inconsciente) de ter filhos não existe e falhamos em responder a este desafio com um véu de siléncio" (SANTOS e col. 2002, p. 37)

\section{9 - Relações de Gênero}

\section{1- Papel estereotipado da mulher}

Muitas vezes, a sexualidade feminina é tomada como natural, instintiva, misteriosa, irracional e até perigosa (PRATES 2001), adquirindo 
um status, que justificaria o controle ideológico do corpo da mulher. A entrevista com Maria revelou que a construção social da sexualidade feminina é atravessada por uma série de estereótipos, que acabam por influenciar, direta ou indiretamente, nas decisōes reprodutivas das mulheres, e está atrelada a uma série de representaçōes das mulheres, a respeito de seu papel na relação amorosa, bem como questões de gênero (BARBOSA 1999). Maria relatou que, nesta gravidez, prefere ter uma filha, pois acredita que a filha é a companhia da mãe, enquanto o filho é companheiro do pai. Ela, também, apontou uma questão cultural: a menina começaria a vida sexual precocemente, por ser "mais fogosa" que o homem e, justamente, por isso, deveria ser mais controlada pela mãe.

\section{2 - Dificuldades de negociação sexual}

$\mathrm{Na}$ prática, observa-se que as mulheres se valem de estratégias, sócio-culturalmente construídas, para "negociar" a contracepção, a maternidade e comportamentos de prevenção às DST/Aids com seus parceiros, adotando um processo de barganha (BARBOSA 1999). A adoção desses comportamentos e valores está atrelada a uma série de representaçōes das mulheres, a respeito de seu papel na relação amorosa, bem como questōes de gênero, dado que a sexualidade e a possibilidade reprodutiva, ainda, são usadas como instrumentos de manipulação social, ou como formas de obtenção de um status pessoal, dentro das relações afetivas (BARBOSA 1999). Quando envolvidas emocionalmente, as mulheres se dispõem a dar "uma prova de amor", que pode envolver, tanto 0 risco de infeç̧ão (DSTs), quanto o risco de engravidar (DUARTE 1999; MERE-ROUCO 1999; VENTURA-FILIPE e col. 2000). Alguns casais sorodiscordantes năo usam preservativos, consistentemente, e afirmam que querem "compartilhar a condenação (HIV) por amor" (SANTOS e col. 2002) e, na economia de trocas simbólicas, as mulheres adotam uma postura de "cumplicidade consentida" em relação ao suposto desejo masculino (BARBOSA e VILLELA 1996; VENTURA-FILIPE e col. 2000).

Para ilustrar esse tipo de "cumplicidade consentida", podemos observar que, no relato de Celina, parece existir um pacto de silêncio entre $o$ casal, pois eles têm relaçőes sexuais sem preservativos, mesmo sabendo que seu companheiro é portador de doenças infecto-contagiosas (sífilis, HIV, Hepatite C) e não se trata. Ela admitiu que, em alguns momentos, coopera ativamente com esse comportamento, pois ela tem uma atitude ambivalente, quanto ao uso de preservativos.

"C: O problema é que ás vezes ele năo aceita o preservativo. Então acaba passando mais virus, mais possibilidades de mutaçס̃es.

E: E cadé a mulher bem comportada?

C: É que às vezes o comportamento nosso não depende só de nós.

$E: E$ depende de que?

C: Da outra pessoa. Porque ás vezes vocé acaba cedendo porque vocé quer estar bem, vocé quer que o relacionamento esteja bem, pra vocé. Por exemplo, eu gosto muito de conversar, discutir. Ah, mas não está certo, não 
está certo! O que não está certo? Já ele não. Ele é uma pessoa que não gosta de discutir, ele não fala sobre HIV, ele năo fala sobre preservativo, ele não gosta de se cuidar. Năo é que ele năo gosta de se cuidar, ele acha que doença pra ele é coisa assim, é muito feio, é muito ruim, é uma coisa que năo deve nem tocar no assunto.

E: Ele năo deve nem tomar os remédios..

C: É.. O médico dele passou para ele fazer os exames de CD4, essas coisas e ainda não chegou o resultado. Mas acusou que ele está com o vírus da Hepatite C. Entăo assim, agora ele já năo bebe mais. Pra mim foi como (tossiu), como a certeza de que ele quer se cuidar mesmo. Entåo ele já năo bebe mais, porque o figado vai inflamar, sei lá. Mas ele não é uma pessoa que vai mudar porque é bom pra mim, é bom pra vocé. Năo. Ah, nåo hoje nåo tô a fim. Entăo pode usar o meu? Vocé pode usar, na hora nåo consegue, na hora nåo quer, sabe assim?

$E$ : Vocé diz o presenvativo feminino?

C: É.

$E$ : Mas é isso que eu estava falando. Tem outras coisas envolvidas, não só vocé vai falar, usou preservativo? Năo! Então está errado! Tem outras coisas envolvidas. Vocé falou, às vezes vocé quer agradar...

C: Năo quer discutir, entăo...

$E: E$ ai, e se vocé engravidar de novo?

C: Eu uso pilula tambem.

E: Vocé quer ter outro filho?

C:Năo. Prefiro nåo correr risco.

E: Por que?

C. De ele também ser... Ser... Infectado.

E: Então vocé nåo quer correr risco de ter uma criança com HIV.

C: Eu năo quero porque eu já tenho muita expectativa e seria mais uma e uma muito perigosa pra mim, entendeu? É muito risco" (Celina, p. 13-14)

Quanto a esse aspecto, sob o prisma psicanalítico, vemos que o sujeito "se oferece em sacrifício" ao outro e, assim, evita a necessidade de se posicionar e se responsabilizar perante seu próprio desejo.

\section{3 - O HIV como uma punição, por mau comportamento da mulher.}

Celina acredita que a infecção por HIV é uma punição, por mau comportamento da mulher, pois ela deveria "se precaver". Ao relatar para sua irmã o diagnóstico de HIV, ela percebeu que havia uma rivalidade entre as duas: sua irmã era "namoradeira" e não foi "punida com o HIV", enquanto Celina, que tinha um "relacionamento seguro", foi "punida". De fato, embora Celina considere seu comportamento como "correto moralmente", ela mesma não adota uma postura de prevenção, no que se refere ao uso de preservativos, nem antes, nem depois do diagnóstico de HIV.

"C: E bom vocé se precaver. Ela foi fazer o exame também, mas para ela foi assim, tipo, uma glória. "Nǎo, ela estar e eu não tô". Me senti pior ainda.

E: Vocés já tinham uma relação de rivalidade?

C. É. Ela tinha uma certa rivalidade comigo. Como eu sou a mais velha, eu sou muito rigida em algumas coisas. É o tipo da coisa. Quando eu soube do HIV, eu me admirei. Por que? Por que eu? Porque para mim isso era coisa de pessoa promiscua. Por que eu, se eu tinha um relacionamento seguro. Eu não vivia trocando de parceiro. Por que eu? Eu não me 
permitia isso. Como ela era muito namoradeira, por que não ela? Por que náo ela? Isso só acontece com outras pessoas. Comigo, nãol" (Celina, p. 6)

Observamos uma contradição essencial entre as concepções morais sobre o comportamento feminino, considerado "correto", e o comportamento efetivo das entrevistadas. Embora muitas delas considerassem estar envolvidas em relacionamentos "seguros", seu relato mostra uma série de relacionamentos fortuitos, ou relativamente instáveis, que eram tomados como "estáveis". Podemos, então, apontar que a forma como elas julgam o envolvimento com seus parceiros dependerá do tipo de envolvimento emocional, que está em jogo. Nesse sentido, o risco de infecção ou de gravidez fica ancorado em sua percepção desse envolvimento emocional, o que as leva à "construção de um relacionamento idealizado". Quando percebem que se trata de um "engodo", forjado por elas mesmas, ressurge a questăo moral: o HIV representa uma punição, por um "mau comportamento" feminino.

\section{4 - A decisão de ter um filho, em função de tradicionais papéis de gênero}

O relato de Dia nos mostra que, muitas vezes, a decisão de ter um filho está fortemente ancorada em tradicionais papéis de gênero, como se a maternidade fosse inerente ao papel da mulher. "Quando a mulher quer ter um filho, enquanto năo consegue o nenê, năo sossega, nę? Eu ficava falando vamos ter outro nené... Vamos?" (Dia, p. 17). O trabalho de Sowell (2002) mostrou que a tendência a adotar tradicionais papéis de gênero é um dos fatores que influencia, positivamente, na decisão de ter um filho.

\section{0- A impossibilidade de amamentar}

Para uma mulher soropositiva, a impossibilidade de amamentar constitui uma situação muito delicada, ou, como refere Campos (1998), com - nascimento do bebê, torna-se evidente que "algo nesta gravidez não é normal". Nesse sentido, o primeiro "sintoma" do HIV é a não amamentação, pois traz visibilidade a algo, que foi cuidadosamente mantido em segredo. Surge uma série de "desculpas" e um repertório é cuidadosamente preparado, para justificar a situação "aos outros", sem, contudo, aplacar a angústia que as mulheres sentem, por não poderem realizar 0 que consideram a "verdadeira expressão da maternidade".

Cátia relatou que se sentiu intensamente angustiada, quando percebeu que outras mães não tinham leite para amamentar, enquanto ela, que tinha bastante leite, não podia dá-lo aos seus bebês. "Eu falava meu Deus, porque eu năo posso dar mamar para os meus filhos? Por que não? Năo está certo! O meu leite, por que esse leite que veio pra mim não está na måezinha do lado, nê?". O leite materno, enquanto signo de doação e completude da diade mãe-bebê, tornou-se um signo de sua Falta, caracterizada pelo HIV. Ela tem, em excesso, o leite que não pode dar aos filhos, porque esse leite, não apenas 
podia infectá-los, como também havia a conviç̧ão de que isso efetivamente já havia acontecido com seu filho anterior.

Ana Carolina valeu-se do repertório de desculpas, citado por Campos (1998): o fato de não amamentar era justificado por ter "hepatite". Quando alguém da equipe médica a abordava, ela mandava "olhar na ficha" (prontuário médico). Isso nos faz pensar que, entre o silêncio de Ana e a "verdade" escrita no papel do prontuário, é possivel perceber o que é da ordem do "inter-dito" (entre ditos), que aponta para o lugar da castração do sujeito (interdito).

"A: É também. Dal todo mundo estava comentando que eu não podia dar mamar, aí eu falava que eu tenho hepatite (risos). Porque foi uma coisa que me veio assim na cabeça, né? Eu tenho também, né?

E: E năo amamentar o bebé, como foi?

A: Porque năo podia amamentar... Ah, eu tinha vontade de amamentar, né? Quando você está grávida, porque dá essa vontade. Mas ai eu falei, năo né? Não posso, fazer o que?

$E$ : Voce tinha leite?

A: Tinha, mas ai eles colocam enfaixado...

E: Enfaixam.

A: Al depois secou.

E: Foi diffcil pra vocé não amamentar?

A: Foi. No começo. Depois fui me acostumando, me adaptando, porque năo posso e também porque a gente vé que se ele pegar vai ser pior, né? Entăo vou me conformar, né?

E: E essa idéia de que vocé tinha hepatite. Como foi as pessoas perguntando "por que?"

A: Al eu năo sou muito, năo sou muito de detalhes. Eu falei da hepatite, pronto. Al quando vinha médico e perguntava e falava e mandava olhar na ficha. Al olhava e "ah, tá, tudo bem". E tínha aquilo, né?"(Ana Carolina)

Os relatos de Mariana e de Márcia apontam para a amamentação como uma suposta insígnia da maternidade. Para Mariana, não poder amamentar "tira o jeito de mãe", e o leite da mulher soropositiva é um "leite ruim". Márcia, por sua vez, afirmou que sua atitude foi de "chorar por dentro", e que seu leite tinha secado, em função da situação de perda do companheiro. Para Márcia, não poder amamentar é perder o "prazer de ser mãe".

A entrevista de Dia mostra uma situação, ainda mais delicada, no que se refere à questão da amamentação. Ela recebeu o diagnóstico de HIV, durante a internação de seu marido, quando estava grávida de três meses $e$, ainda, amamentando sua filha, de dois anos de idade. A necessidade de interrupção abrupta da amamentação da filha mais velha lhe causou verdadeiro horror.

Outro relato interessante foi o de Silvia. Silvia contou que alimentou seu filho com um "copinho", pois, na maternidade onde teve seu filho, "não podia entrar mamadeira". Mas, o fato de não poder amamentar causou certo desconforto para Silvia, fazendo com que ela, também, "inventasse alguma 
coisa", para justificar a não amamentação para o outro. Sabemos que o uso de "copinho", na alimentação do recém-nascido, constitui uma estratégia de puericultura, que permite que a mãe, que deseja amamentar, possa se adaptar gradativamente ao processo, e, assim, que o bebê não corra o risco de se condicionar ao bico da mamadeira, abandonando o peito da mãe. No entanto, no caso da mulher soropositiva, que não vai amamentar, podemos questionar o motivo do impedimento do uso da mamadeira no pós-parto. Se existe uma "diretriz" da maternidade, que visa estimular a amamentação, observamos que, muitas vezes, o que se apresenta como "regra" para benefício de alguns, não costuma ser relativizado. Parece que, no caso relatado por Silvia, a diretriz, que visa estimular a amamentação, não leva em consideração situaçōes específicas, e o sujeito fica, mais uma vez, desconsiderado, em sua subjetividade.

Débora relatou que, embora tivesse leite no final da gravidez, no pósparto seu leite secou. Nesse caso, o que se produziu foi um sintoma (o leite secou), que justificava a impossibilidade de amamentar. Por um mecanismo de inibição, o sintoma visou contornar a angústia implicada.

\section{1 - Relação especular do sujeito [ I (A)]}

A forma como o sujeito avalia a decisão de uma mulher soropositiva, que decide ter filhos é, afinal, a forma como ela vê sua própria decisão de ter um filho (ZIZEK 1992). A maioria das entrevistadas caracteriza a decisão de uma mulher soropositiva, quanto ao desejo de ter filhos, "uma loucura", ou, uma "irresponsabilidade".

"E: E vocé acha que essa mulher tem o direito de ter o filho dela?

$A$ : $E$. A minha sogra falou "ah, que mulher doida". Sabe? Ah, ela tinha direito, se quiser arriscar. Normal" (Ana Carolina).

"E: E o que vocé acha de uma mulher que é portadora do HIV e resolve ter um filho?

B. Eu tive uma amiga na casa de apoio. Ela teve porque ela quis. E o menino năo nasceu como vírus. E ela ficou internada aqui no Emillio Ribas, mais morta do que viva. (...) Quando ela saiu daqui ela foi para uma casa de apoio junto com o N., ela conheceu um rapaz aqui que também tinha. Ela falava pra mim, eu quero ter um outro filho. Eu falava, você é loucal Eu quero, eu quero, eu quero. E ela teve um menino. O pai é HIV e ela e o menino năo tem. (...) Mas nunca se sabe se vocé vai por um bichinho no mundo para sofrer. E se nasce um aidético, aí? Na minha epoca abortavam as crianças aidéticas, dá dó dessas crianças" (Bianca, p. 11-12).

Duarte (1999) e Meré-Rouco (1999) referem-se à idéia de que uma situação de risco poderia servir de "prova de amor", e que, algumas mulheres, ao envolverem-se emocionalmente, expõem-se ao risco de infecção e gravidez. Santos e col. (2002) comentam que alguns casais sorodiscordantes não usam preservativos $e$ afirmam que querem "compartilhar a condenação (HIV), por amor". Barbosa e Villela (1996) interpretam que, para algumas mulheres, 0 ato de amor implica abnegação e subordinação ao desejo masculino. 
No que diz respeito a esses aspectos, podemos notar, na entrevista de Dia, que a relação entre desejo de ter filhos e demonstração de amor, fica suspensa, em função do diagnóstico de HIV: para ela, um casal soropositivo ou sorodiscordantes, que deseja ter filhos, comete "uma loucura". Ela discorda da posição de casais, que "bancam" o risco de terem um filho soropositivo, ou de casais sorodiscordantes que tentam engravidar (já que há também o risco de infecção do parceiro soronegativo). Ela disse que, quando um casal decide ter filhos, vai ter que conviver com "um fantasma" (do HIV), e que essa decisão nada tem a ver com um ato de amor, pois, para ela, "O amor é poder zelar pela outra pessoa. Não querer o mal da outra pessoa".

Para Dia, decisões reprodutivas do outro devem envolver apenas aspectos objetivos, mas ela se esqueceu de que suas próprias decisões foram tomadas, dentro de um contexto "subjetivo". Embora ela procure tomar uma posição pragmática, quanto a si mesma (toma juizo, faz laqueadura, não se envolve com outra pessoa), uma série de questóes subjetivas, que causam sofrimento, permanecem pendentes e intocadas. Ao manter relações sexuais desprotegidas com seu companheiro, que era usuário de drogas injetáveis, ela correu o risco de engravidar e ser infectada pelo HIV, embora tivesse tido acesso às informaçōes sobre a forma de transmissão do HIV. Parece que seu companheiro não "zelou" por ela, e ela "não zelou por seus filhos", mas podemos pensar que, se "o amor é poder zelar pela outra pessoa. Năo querer o mal da outra pessoa", como o sujeito pode zelar pelo outro, ou por si mesmo, quando o próprio sujeito não quer, ou não pode, posicionar-se perante o próprio desejo inconsciente? 


\section{3 - Contribuições da Psicanálise para abordar o desejo e gozo, em mulheres vivendo com HIVIAids: "do sujeito" na busca do \\ "para além do sujeito"}

Uma contribuição da Psicanálise torna-se possivel, quando situamos o campo do desejo em um registro distinto do âmbito natural e/ou biológico, colocando-o ao lado do erógeno, no sentido freudiano do termo. Isso se evidencia, quando tomamos a incidência do HIV no corpo dos sujeitos entrevistados. Muito embora o HIV incida no corpo de todas as entrevistadas, não há uma mesma inscrição, pois a incidência do HIV no corpo biológico pode resultar em uma inscrição diversa, no corpo erógeno do sujeito em questão. A diferença se dá na forma como a sexualidade é vivida no psiquismo de cada sujeito e, além disso, a sua posição quanto à sexuação vai revelar diferentes possibilidades. Nesse sentido, mediante o que foi exposto no capitulo II, podemos afirmar que tomar-se mãe é diferente de tomar-se mulher, assim como sexualidade é diferente de sexuação, pois esta diz respeito à posição do sujeito em relação à castração e ao significante fálico.

Seguindo Lacan, e avançando na teorização freudiana (conforme abordado no capítulo II), consideramos que a maternidade e a amamentação não podem ser caracterizadas como significantes do feminino. Assim, não importa se o sujeito vai ter filhos ou não, pois a Psicanálise preocupa-se em saber que posição ele ocupa em relação ao desejo (se posição masculina ou feminina). Essa questão permeou toda a construção teórica deste trabalho, pois não pretendemos caracterizar o desejo da mulher soropositiva como "um desejo natural de ter filhos", assim como não caracterizamos a maternidade e a gravidez como insígnias do feminino, pois, isso seria incorrer em uma postura essencialista, ou, ainda, em um processo de idealização do feminino.

Podemos observar, no discurso de mulheres soropositivas, aspectos relacionados à idealização da maternidade. Evidentemente, isso não se dá apenas em relação a esse grupo de sujeitos, pois sabemos que o posicionamento do sujeito, em relação ao desejo e ao gozo, é uma questão estrutural. Entretanto, não podemos deixar de notar que, o lugar que a maternidade e a gravidez ocupam no desejo das entrevistadas parece responder ao um registro imaginário, ou a uma produção que visa tamponar a Falta. Isso se evidencia no momento em que as entrevistadas se deparam com um impedimento, como no caso da amamentação. Nesse sentido, a impossibilidade de amamentar é, não apenas um "sintoma do HIV", mas também algo que vai incidir na identidade da mulher. O que se evidencia é a diferença entre ser uma mulher saudável e ser uma mulher soropositiva. Observamos, então, que não amamentar frustra um tornar-se mulher idealizado, ou, ainda, uma identificação idealizada de feminino. 
Baseadas no grafo do desejo, certos significantes, que ficariam encobertos, se visássemos apenas a análise do sentido, foram privilegiados e, assim, o trabalho se direcionou para um além do sentido, ampliando questões. As técnicas de investigação (testes, inventários, inquéritos) desconsideram os significantes fundamentais de cada paciente. Nesse tipo de análise, os sujeitos são tomados em grupo, investigando sua relação imaginária com a doença e denotando a relação do sujeito com um grupo, estatisticamente determinado. $O$ resultado dessa investigação é, também, imaginário, e se restringe no nivel m-i(a) do grafo do desejo (LACAN 1998a). Nesse nivel, a relação, que o sujeito tem com o outro, é uma relação especular.

Se tomarmos o matema do grafo do desejo, articulado à proposta de análise da ideologia de Zizek (1992), é possivel, a partir dos discursos das mulheres entrevistadas, observar como se dá o processo de identificação imaginária [i(a)], na sua relação com a identificação simbólica [ I(A)].

$\mathrm{Na}$ identificação imaginária [i(a)], temos os traços positivos descritivos, que representam o sujeito, ou algo que gruda ao individuo e se oferece ao olhar, como o sujeito se vê (ZIZEK 1992). No caso das entrevistadas, chamam nossa atenção os significantes: soropositiva, HIV, mãe, grávida, desorientada, acolhimento, apoio, vítima, entre outros. A imagem que as mulheres entrevistadas têm de si mesmas indica que seriam mulheres marcadas pela revelação do diagnóstico do HIV. Mediante 0 impacto da situaçăo, tornam-se "vitimas" vulneráveis, que precisam de apoio e orientação, para que suas decisōes reprodutivas conduzam a um "final feliz", qual seja, "ter um bebê soronegativo". Nesse nivel de identificação imaginária, as mulheres assumem o suposto papel idealizado da "boa paciente" que, ao adotar as recomendações da equipe de saúde, sem queixas ou questionamentos, será acolhida e aceita.

$\mathrm{Na}$ identificação simbólica [I(A)], temos "o lugar de onde o sujeito se observa como sendo digno de ser amado" (ZIZEK 1992). Isso diz respeito à forma como o sujeito olha para o outro, o que indica, afinal, a forma como ele olha para si mesmo (o "ser para o outro" é o "ser para si"). As mulheres entrevistadas percebem "mulheres soropositivas que decidem ter um filho" como aquelas que cometem uma "loucura" ou uma irresponsabilidade. 0 traço que caracteriza as entrevistadas é sua posição irresponsável perante o próprio desejo. Sendo irresponsáveis e culpabilizando ao Outro, estabelecem uma pantomima histérica, que não cessa de demandar e apontar a insatisfação do desejo. As mulheres entrevistadas "agarram-se" à identificação imaginária, assumindo uma identidade de "vítimas" ou a posição de objeto de desejo do Outro, oferecendo-se como "objeto para outro", mantendo a identificação especular, em uma tentativa de serem aceitas (amadas). O que a identificação imaginária tenta encobrir (e não consegue) é, justamente, o trauma constituído, pelo fato de que o sujeito é uma vítima trágica perante o Real irrepresentável, pois não lhe resta outra saida, a não ser, haver-se com a questão da castração. 
É interessante observar que a maioria das mulheres entrevistadas avalia as decisões reprodutivas de mulheres soropositivas, de uma forma paradoxal: o que se aplica para o outro, não se aplica para si mesma, pois, suas próprias decisões reprodutivas baseiam-se em uma série de justificativas, responsabilizando ao outro. Contudo, em relação às decisões reprodutivas do outro, sua visão é bastante pragmática: trata-se de uma loucura ou irresponsabilidade, que poderia e, em muitos casos, deveria, ser evitada.

Introduzindo a dimensão do para além do sujeito, precisamos realizar uma articulação com a questão da fantasia, uma vez que esta é uma construção do sujeito, que tenta fazer frente à questão do Real. A construção que as entrevistadas realizam, para fazer frente ao Real irrepresentável, é um sacrifício. O sujeito se oferece, em sacrifício, ao desejo do Outro, e ter um filho transforma-se em uma provação (provar com uma ação). $O$ sujeito não se responsabiliza, nem pelos seus atos, nem pelo seu desejo inconsciente, pois foi o Outro que lhe impós esta "missão" (a gravidez foi "um acidente", "foi meu marido quem quis", "toda mulher quer um filho e eu não queria ser diferente", "foi um descuido", "aconteceu, virou Manchete!" sic). Ocorre uma produção, que visa tamponar uma Falta, algo que Freud (1996h) refere como sendo da ordem da penisneid. Mas, os relatos das mães deixam entrever que não bastou engravidar: resta $\circ$ HIV, enquanto representante do desconcerto do sujeito perante a Falta. A fantasia construída, enquanto uma tentativa de pacto com o desejo do Outro, acaba por desnudar o desencontro, o silêncio, a dor da solidão e a angústia.

Essa posição se repete nas relações conjugais-afetivas, e tende a se repetir na relação com a equipe de saúde. No que concerne à relação das mulheres entrevistadas com a equipe, foi possivel observar que há, também, uma relação especular: as mulheres se identificam com a forma como a equipe multidisciplinar as trata, ou, em outras palavras, a forma como elas tratam a doença varia, em função do que a equipe (como um Outro) Ihes apresenta, como referência. Dessa forma, ao manter-se na relação especular, o sujeito impede o aparecimento da questão do desejo, e isso pode ocorrer, porque o Outro é mantido intocável, no lugar de suposto saber absoluto. Deixar o profissional de saúde em uma posição intocável e intacto, como lugar de suposto-saber, tem, como conseqüência, que a paciente passa a carregar, como uma cruz, o objeto a, que pode reaparecer na passagem ao ato (RABINOVICH 1989). Portanto, abandono ou baixa adesão ao tratamento, gravidez, não seguimento das recomendações $e$ encaminhamentos da equipe podem constituir situações de explicitação da relação do sujeito com o Outro absoluto.

Recentemente, houve uma mudança na política de atendimento às gestantes soropositivas, incluindo treinamentos para "humanização e acolhimento", com a justificativa de prevenção da TMI e pautados na Saúde Pública. Embora seja possivel perceber essa mudança, em relatos das 
mulheres, ainda observamos posicionamentos ideológicos e julgamentos moralistas, por parte de alguns membros da equipe de saúde. Sob o ponto de vista do discurso médico, a questão da idealização incide na construção de um "ideal de paciente", ou seja, o paciente que adere incondicionalmente, tanto ao tratamento, quanto às prerrogativas do profissional de saúde. Há uma comparação entre o "paciente ideal" e as "mães soropositivas loucas que decidem ter filhos". Postura "tutorial" e de mestria, por parte da equipe, perpetua a exclusão das questōes subjetivas das pacientes. O significante "loucura" é digno de nota, pois, ao caracterizar as mulheres soropositivas e que decidem ter filhos, como "loucas", instaura-se uma exclusão, pois a loucura é, usualmente, excluída da sociedade (FOUCAULT 1993).

Foi possivel observar que, quando as mulheres soropositivas demandam, na verdade, fazem surgir a dimensão do desencontro entre demanda e desejo. Se as políticas de acolhimento pretendem ser uma resposta às demandas histéricas, na verdade, o que se observa é uma surpresa: do lado das equipes, a posição é "estamos acolhendo, mas porque ainda subsiste um mal estar?". Quanto a isso, Zizek (1992) comenta que "A distância entre a demanda e o desejo é o que define a posição do sujeito histérico: segundo a fórmula lacaniana clássica, a lógica da demanda histérica é: "Eu the peço isso, mas, na verdade, peço-lhe que recuse meu pedido, porque não é isso"! (ZIZEK 1992, p.110). Do ponto de vista das pacientes, desvela-se o desencontro: "se vocês pensam que era isso que eu queria, se enganam. Não é nada disso". Esse é um exemplo da histérica, pondo em xeque o discurso do mestre.

No que concerne à questão da angústia, foi possivel perceber, no discurso das mulheres, que podemos desdobrar planos em que ocorre sua emergência: se, a principio, a situação da gravidez traz, em si, uma vivência angustiante, a situação de diagnóstico de HIV, concomitante à gravidez, permite a evidenciação de uma condição, em que a angústia é, ainda, mais significativa. Entretanto, a partir de Lacan (1997b), a angústia é entendida como um sinal, que permite vislumbrar, sem dúvidas, que questões inconscientes estão em marcha. Nesse sentido, desejo e angústia (assim como gozo) caminham juntos, indicando que o sujeito tem que se haver com a emergência do objeto $a$, ou seja, do Real. Nossa interpretação pode demonstrar que as mulheres soropositivas, que lidam com a angústia de forma disruptiva ou menos "adaptada", têm menor possibilidade de acolhimento de suas questões inconscientes. As mulheres que acionam mecanismos de defesa (negação, sublimação, formação reativa, entre outros), para lidar com essas questōes, podem vir a ser acolhidas (tanto pela equipe, quanto pela família). Entretanto, esse processo não ocorre sem conseqüências, tanto para o próprio sujeito, como para a equipe que as atende, já que, aquilo que foi recalcado, pode retornar, sob a forma de sintomas ainda mais desconcertantes.

Mediante a explicitação do percurso teórico, para abordar a questão da gravidez e maternidade em mulheres vivendo com HIVIAids, valemo-nos, 
agora, de uma metáfora, citada por Zizek (1992), para ilustrar a relação do sujeito com o desejo e o gozo, no que se refere à maternidade: na famosa pintura de Rosetti, Ecce Ancilla Domini (gravura reproduzida no inicio deste trabalho), que retrata Maria, no exato momento de sua interpelação pelo arcanjo Gabriel, Maria recebe a missão de conceber, imaculada, o filho de Deus. Nessa pintura, ela reage, recuando, pesarosamente, em um canto, pálida e fatigada, como se perguntasse, a si mesma, "Por que fui eu a escolhida para essa missão estúpida? Por que eu? Esse fantasma repugnante, o que ele quer de mim realmente?". A questão histérica não é nada mais que isso, uma resposta à interpelação malograda do Outro, ou seja, "Por que sou o que você me diz que eu sou?". Como o sujeito pode assumir, plenamente e sem coerção, a sua missão simbólica?

A anunciação de Maria pode ser tomada como uma metáfora para a interpelação malograda do Outro, que encarrega o sujeito de uma missão fundante, sob o ponto de vista estrutural, pois fornece a identidade simbólica, e é, ao mesmo tempo, uma missão absurda, pois desconcerta o sujeito e constitui o verdadeiro trauma. A questão histérica abre o abismo do que está "no sujeito, para além do sujeito", ou seja, para o objeto dentro do sujeito, objeto este, que resiste à interpretação (à inclusão na rede simbólica). Para Maria, a questão é "qual é esse objeto excedente em mim que faz o Outro me interpelar, causando horror, retirando-me do lugar onde era possível instalar-me (identificação imaginária)?".

Diante da saudação do anjo, não resta outra saída à Maria, pois ela aceita sua missão e diz "Eis aqui a escrava do Senhor, faça-se em mim, segundo a tua palavra". O que antes era um traço, tornou "o traço identificatório": a virgem tornou-se "A Virgem Maria, mãe de Deus, bendita entre as mulheres". Maria oferece-se ao sacrificio, nessa missão inexorável, pois afinal, que pode ela, perante o Senhor Deus onipotente, onipresente, onisciente? "Eis a escrava do Senhor. Então, que seja feita Vossa vontade, não a minha". Maria, a mãe de Jesus, oferece-se ao sacrifício, pois o cerne da religião cristã está baseado no enigma insuportável do desejo do Outro absoluto (Deus). Cabe ao sujeito, submeterse para receber um novo lugar para si: Maria ama a Deus e, por isso, será salva e bendita (bem-dita). Fora do âmbito religioso, não há nada que o Outro possa dizer, que vá "bendizer", pelo contrário, o Outro profere a "maldição", ou aponta o "mal-dizer", que é tudo o que o sujeito consegue fazer. Esse constitui o verdadeiro trauma: a subordinação do sujeito, ou seu assujeitamento ao Inconsciente.

Nosso intuito, ao trazer essa metáfora da anunciação de Maria, para ilustrar nosso trabalho, diz respeito ao fato de que observamos que as mulheres se posicionavam, diante de sua situação, com o mesmo desconcerto de Maria, perante sua "missão". As entrevistadas se perguntavam "por que eu? Por que isso (o HIV) tinha que acontecer comigo?". Embora essa questão remeta para a possivel histericização do sujeito, o que observamos é que as mulheres assumem a posição de 
"sacrificio", na busca de uma "salvação" (que, na verdade, diz respeito ao seu desejo de serem aceitas e amadas pelo outro). Outro aspecto que, também, chamou nossa atenção, diz respeito ao tipo de relação que as entrevistadas estabelecem com o Outro: na maioria dos casos, verificamos um esforço consciente em mantê-lo na condição de Outro absoluto. Nessa relação especular idealizada, que procura manter o narcisismo do sujeito, sempre, acaba por se mostrar claudicante, e o Real do gozo se evidencia, não importando o número de estratégias que o sujeito tenta realizar, para tamponar a Falta. Na metáfora da anunciação de Maria, o nascimento do "Salvador" é garantido pelo Outro Absoluto (Deus), mas como ficam as mulheres entrevistadas, que lidam com "supostos" Outros absolutos? Portanto, não há um Outro, que Ihes garanta um filho desejado "perfeito", evidenciando o engodo e, dessa forma, a angústia é inevitável.

Podemos, então, a partir dos dados obtidos nesse trabalho, em relação à teoria psicanalítica, destacar algumas considerações relevantes:

- O discurso das mulheres mostrou que seu comportamento não é, necessariamente, determinado pelas orientações recebidas pela equipe multidisciplinar de saúde. Entretanto, foi possivel perceber que as entrevistadas tinham necessidade de se mostrarem como "boas pacientes", aderentes ao tratamento, e, sobretudo, gratas pelo suporte institucional recebido. Embora 0 apoio e acolhimento, por parte da equipe, sejam bem vindos, não são determinantes para a adesão ao modelo de identificação imaginária da "boa paciente". Não é porque o sujeito vai procurar tratamento, que significa que vai seguir as orientaçōes médicas, ou que vai se implicar nessas orientaçōes.

- Decisōes reprodutivas não são pautadas pelos resultados relativos ao estado sorológico da criança (se o filho gerado vai ter, ou não, o HIV), mas por questões inconscientes, que colocam as mulheres em face do risco de engravidar. O risco de transmissão do vírus, para o filho, que, atualmente, é relativamente baixo (quando seguem as orientações pertinentes), embora, aparentemente, seja determinante na decisão de levar uma gravidez adiante, não é determinante, no que diz respeito ao risco de engravidar. Independente do risco de TMI, há um comportamento de risco para engravidar, sob pena de que, uma vez grávida, a mulher venha a considerar a possibilidade de realizar um abortamento (independentemente do status sorológico do feto). Quando a gravidez se apresenta como um fato, ela adquire um outro status: uma espécie de "provação", cujo objetivo é gerar um rebento soronegativo.

- A gravidez da mulher soropositiva tem, entre outras, a função de uma tentativa de restauração narcísica. O diagnóstico de HIV implica perda do corpo saudável, e a geração de um filho soronegativo funciona como um tamponamento de uma perda de gozo. O resultado do status sorológico do bebê é representante dessa operação de tamponamento: 
a. Se o bebè é soropositivo, surgem significantes de "culpa", "castigo", "punição", entre outros, e, então, o resto, não simbolizável pelo tamponamento, vem à tona;

b. Se o bebê é soronegativo, surgem significantes como "vitória" ou "salvação", mas, o resto não simbolizável persiste, na forma de "medos sem sentido", relacionados com o "medo de que a mãe venha a morrer e não possa cuidar do bebê", ou o "medo de que alguém tome seu filho", entre outros.

Uma articulação da Psicanálise e Saúde Pública possibilita vislumbrar, portanto, que a relação da mulher soropositiva, com a equipe de saúde, dá-se em um nivel especular, e isso tem conseqüências terapêuticas. Um dos aspectos, que chama a atenção de profissionais de saúde, é que, uma pessoa que procura tratamento, não necessariamente vai segui-lo, ou seja, não é porque uma mulher procura orientação médica, que há garantias de que ela seguirá ou se implicará nessa orientação, embora, do ponto de vista do profissional, o fato de estar informando, detalhadamente, constitui uma tentativa de assegurar que sua função foi cumprida, como se isso constituisse a garantia de acolhimento. A Psicanálise, ao considerar o estatuto paradoxal da pulsão, permite que a questão do mal-estar do sujeito, em relação à Falta, seja considerada. Uma relação de cunho especular, como a que subsiste à relação da soropositiva com a equipe de saúde, tenta encobrir a Falta e vai trabalhar uma adaptação ao modelo idealizado, tanto de paciente, quanto de política de Saúde Pública. Concluímos que a Psicanálise traz uma contribuição para uma reflexão sobre o cuidado terapêutico e o acolhimento, pois permite a inclusão das idiossincrasias na relação do sujeito com o outro/Outro, e do sujeito no campo do desejo $e$, assim, a partir da escuta do campo do sem sentido ou para além do sentido, viabiliza o resgate da singularidade do desejo inconsciente do sujeito, em questão.

Para finalizar este trabalho, apresentamos a posição da Psicanálise, no que diz respeito à Ética. Tomamos a infecção, pelo HIV, como evidenciação de uma perda do corpo saudável, representando a incidência da castração, que pode, ou não, fazer surgir uma questão para o sujeito. Mas, o que é saudável para a medicina e o que é saudável para a Psicanálise e, nesse sentido, a quem cabem as determinações normativas quanto ao desejo inconsciente do sujeito?

"Para ter acesso a esse ponto, situado para-alem da reduçăo dos ideais da pessoa, é como objeto a do desejo, com aquilo que ele foi para o Outro em sua ereção de vivente, como o wanted ou o unwanted de sua vinda ao mundo, que o sujeito é chamado a renascer para saber se quer aquilo que deseja (grifo nosso)... É esse o tipo de verdade que, com a invençăo da análise, Freud trouxe à luz. Esse é o campo em que o sujeito, com sua pessoa, tem que pagar sobretudo pelo resgate de seu desejo. E é nisso que a psicanálise ordena uma revisão ética" (LACAN 1998f, p. 689) 
A investigação médica, sobre o corpo feminino, não leva em consideração o desdobramento entre o corpo, biologicamente, tomado como feminino, e o corpo da mulher, pois, no saber médico, o corpo não é tomado como lugar de gozo, conforme comenta Clavreul (1983).

\begin{abstract}
"No que diz respeito aos próprios médicos, não cabe esperar nem desejar que eles saiam do discurso que é o deles. Bem ao contrário: seus doentes nada têm a esperar deles, senăo que the sejam fiéis. Uma maior consciéncia do poder da medicina como discurso daria, entretanto aos médicos uma preocupação menor em estabelecer seu saber como poder e em manter uma ligação friorenta a premogativas de uma outra era, que ninguém pensa seriamente em Ihes contestar. Năo penso que o tête-à-tête do médico consigo mesmo, com sua ciência, com a opiniăo e a vigilância dos confrades the proporcione tantas alegrias quanto insinuam certas polemicas. Pois foi também para eles que Hipócrates constituiu o corpo com lugar de saúde. Mas, o corpo não deixa esquecer que ele é antes de mais nada o lugar do gozo" (CLAVREUL 1983, p. 37).
\end{abstract}

A contribuição da Psicanálise, para o campo da Saúde Pública, segue a direção da Ética. Lacan evidencia que as relações entre Psicanálise e Medicina apontam para diferentes perspectivas, a respeito do sujeito, o que, sem dúvida, tem conseqüências éticas.

\begin{abstract}
"A questấo é outra; é propriamente desta leitura pela qual o médico é capaz de conduzir o sujeito ao que existe de um certo paréntese, começando do nascimento, acabando na morte, e comportando questóes que văo do nascer ao morrer. Em nome de qué os médicos devem estatuir sobre o direito ou năo de nascer? Como responderăo às exigencias que bem rapidamente irăo concluir das exigéncias da produtividade? Pois, se a saúde passa a ser o objeto de uma organizaçăo mundial, a questão está em saber em que medida ela é produtiva. O que poderá o médico opor aos imperativos que o faziam um empregado desta dominaçăo universal da produtividade? Ele năo tem outro terreno senăo esta relaçăo pela qual ele é o médico, a saber, a demanda do doente. No interior desta relaçăo firme onde tantas coisas se produzem é que está a revelaçăo desta dimensăo em seu valou original, que nada tem de idealista, mas é exatamente o que eu disse: a relação ao gozo do corpo" (LACAN 1966, p. 11).
\end{abstract}

Para a Psicanálise, há uma diferença fundamental entre "dizer o bem", que se refere ao âmbito da consciência, em sua relação com o superego, e o "bem dizer", que visa à produção de significantes, referentes ao modo de gozo de sujeito. Evidentemente, distante de concepções moralistas, a Ética da Psicanálise leva a questão do desejo às ultimas conseqüências, mostrando que a única traição, que o sujeito pode, efetivamente, realizar, é a traição do próprio desejo inconsciente.

"Proponho que a única coisa da qual se possa ser culpado, pelo menos na perspectiva analitica, é de ter cedido de seu desejo. (...) Ele freqüentemente cedeu em seu desejo por um bom motivo, e freqüentemente 0 melhor. Isso também năo nos deve espantar.(...) Fazer as coisas em nome do bem, e mais ainda em nome do bem do 
outro, eis o que está bem longe de nos abrigar não apenas da culpa, mas de todo tipo de catástrofes interiores. Em particular, isso não nos abriga certamente da neurose e de suas consequéncias. Se a análise tem um sentido, o desejo nada mais é do que aquilo que suporta o tema inconsciente, a articulação própria do que faz com que nos enraizemos num destino particular, o qual exige com insisténcia que a divida seja paga, e ele torna a voltar, retorna e nos traz sempre de volta para uma certa trilha, para a trilha do que é propriamente nosso afazer" ( LACAN 1997 , p. $382-383$ )

O ato de fundação do sujeito (LACAN 1998a) já é, em si, não apenas uma condição ontológica, mas lógica, e que tem incidência Ética, à medida que, desde o princípio, suscita, ao sujeito, a questão do desejo.

"Separare, separar, conclui-se aqui em se parere, gerar a si mesmo. (...) Aqui, é por sua partição que o sujeito procede a sua parturiçăo. $E$ isso náo implica a metáfora grotesca de que ele se dé à luz de novo. (...) Parere é, antes de mais nada, proporcionar (um filho ao marido). Por isso é que o sujeito pode se proporcionar o que the diz respeito aqui, um estado que qualificaremos de civil.(...) Separare, se parere: para se enfeitar com um significante ${ }^{1}$ sob o qual sucumbe, o sujeito ataca a cadeia, que reconduzimos à conta exata de um binarismo, em seu ponto de intervalo. O intervalo que se repete, estrutura mais radical da cadeia significante, é o lugar assombrado pela metonimia, veículo, ao menos como o ensinamos, do desejo" (LACAN 1998a, p. 857-858).

Portanto, quando dizemos que as entrevistadas se "desresponsabilizam" por seu desejo, baseamo-nos em Lacan (1997), que deixa claro que o sujeito assim procede, "por um bom motivo". Mas, isso não as impede de "viver catástrofes", ou, "serem neuróticas". Sem dúvida, relatos das entrevistadas evidenciaram que sua tentativa de lidar com a Falta e a castração não as protege de vivenciarem angústias e sintomas, que, embora sejam motivo de suas queixas, acabam por proporcionar seu "distanciamento" da questão do desejo, enquanto causa.

Consideramos importante destacar, com isso, que existe uma diferença fundamental entre a posição de julgamento moral, que aponta as decisōes reprodutivas das mulheres vivendo com HIVIAids, como sendo provenientes de um desejo "irresponsável" ou "louco", e a posição Ética da Psicanálise, que permite caracterizar que as mulheres soropositivas se "desresponsabilizam", por seu desejo inconsciente, em função de sua dificuldade estrutural de suportar a angústia, que a castração e a Falta engendra.

O papel da Psicanálise é, nesse âmbito, um convite: que o sujeito possa suportar (no sentido de dar suporte) o lugar da Mulher que, para além de "um simples objeto de desejo" é, de fato, aquela que ocupa o lugar do "objeto precioso primordial", para sempre perdido (LACAN 1992, p. 32).

\footnotetext{
1 "Se parer du signifiant: se parer, além de significar "gabar-se, vangloriar-se", evoca com "séparer" (separar); parer significa "proteger, aparar, enfeitar, ornamentar". (nota do tradutor dos Escritos)
} 
Nesse lugar especial, o que se engendra é uma relação particular com as palavras, sem que, contudo, o sujeito pretenda preencher a Falta. Em uma análise, o que realmente se evidencia é que o sujeito constrói um engendramento do vazio e, então, torna-se digno de ser portador de seu agalma. Quanto às mulheres vivendo com HIVIAids, esse convite tem um apelo especial: para além de se identificarem como "portadoras vitimas do HIV", que elas sejam capazes de "separare, se parere", como diz Lacan, e assim, constituírem-se como responsáveis por "dar à luz" a si mesmas, como sujeitos desejantes. Como portadoras dignas desse "verdadeiro objeto precioso", podem, enfim, dizer que suas decisões reprodutivas constituem uma passagem para a vida, naquilo que ela oferece de mais singular e Real. 


\section{Referências Bibliográficas}

Abadia-Barrero CE. Growing up in a Word with Aids: social advantages of having Aids in Brazil. Aids Care. 2002; 14:417-423.

Alvarenga AT. A Saúde Pública como campo de investigação interdisciplinar e a questão metodológica. Saúde e Sociedade. 1994; 2: 22-41.

André S. O que quer uma mulher. Rio de Janeiro: Jorge Zahar;1987.

Ayres JR. et al. Vulnerabilidade e prevenção em tempos de Aids. In: Barbosa R, Parker R. Sexualidades pelo avesso: direitos, identidades e poder. Rio de Janeiro, IMS/UERJ; São Paulo: Ed. 34; 1999. p. 49-72.

Ávila MB. Encarte: A Contracepção em Debate: velhos conflitos, novas perspectivas. JORNAL DA REDE SAÚDE. 2000; 20: 1-8.

Azevedo K. Transmissão vertical do vírus da Imunodeficiência Humana como reduzir o risco? DST - Jor. Bras. Doenças Sex transm. 2001; 13: $49-53$.

Bassett M. Keeping the M in MTCT: Women, Mothers and HIV prevention. American Journal of Public Health. 2001; 91:701-703.

Barbieri T. Sobre la categoría Género: una introducción teóricometodológica. In: Azerêdo, S \& Stolcke, V (orgs). Direitos Reprodutivos. São Paulo: FCC/ DPE;1991. p. 25-45.

Barbosa RHS. Aids e Saúde Reprodutiva: novos desafios. In: Giffin K. (org). Questões da Saúde Reprodutiva. Rio de Janeiro: Ed. Fiocruz; 1999.

Barbosa R, Villela W. A trajetória feminina da Aids. In: Parker R, Galvão (orgs). Quebrando o silêncio: Mulheres e Aids no Brasil. Rio de Janeiro: Relume-Dumará, ABIA, IMS/ UERJ; 1996. p.17-32.

Barbosa R. Negociação sexual ou sexo negociado? Poder Gênero e Sexualidade em tempos de Aids. In: Barbosa R, Parker R (orgs). Sexualidades pelo avesso: direitos, identidades e poder. Rio de Janeiro: IMS/UERJ; São Paulo: ed. 34; 1999. p. 73-88.

Barbosa RM, Knauth DR Esterilização feminina e cultura médica. Os casos de São Paulo e Porto Alegre. Caderno de Saúde Pública. 2003; 19 (supl 2): 365-376.

Bardin L. Análise de conteúdo. Lisboa: Edições 70, 1977. 
Barros MRR. O bebê de proveta e a questão da paternidade. In: Forbes J. (org). Psicanálise: problemas ao feminino. Campinas: Papirus; 1996.

Berquó $E$ (org). Sexo e vida: panorama da saúde reprodutiva no Brasil. Campinas: Editora Unicamp; 2003.

Berer $M$ (cols). Mulheres e HIVI AIDS: um livro sobre recursos internacionais. Informação, ação e recursos relativos às mulheres HIVI AIDS, saúde reprodutiva e relações sexuais. São Paulo: Brasiliense; 1997.

Bíblia Sagrada. $11^{a}$ ed.São Paulo: Edições Paulinas; 1982.

Campos R. Aids: trajetórias afetivo-sexuais das mulheres. In: Bruschini C. Horizontes plurais: novos estudos de gênero no Brasil. São Paulo, FCC; São Paulo: Ed. 34; 1998. p. 85-109.

Costa Dias EA. Entre o desejo e o risco: os sentidos da gravidez na assistência à Aids. São Paulo; 1999. [Dissertação de Mestrado: Pontifícia Universidade Católica].

Custódio et al. Vertical Transmission of HIV in Rio de Janeiro, Brasil. Aids. $2003 ; 17$.

Duarte LFD. O Império dos sentidos: sensibilidade, sensualidade e sexualidade na cultura ocidental moderna. In: Heilborn ML. Sexualidade: 0 olhar das ciências sociais. Rio de Janeiro: Ed. Jorge Zahar; 1999.

Ferreira ABH. Dicionário Aurélio Escolar da Língua Portuguesa. Rio de Janeiro: Editora Nova Fronteira; 1988.

Forbes J. Da palavra ao gesto do analista. Rio de Janeiro: Jorge Zahar, 1999.

Foucault M. A casa dos loucos. In: Microfísica do poder. Rio de Janeiro: Graal; 1993.

Freud S. Obras completas. Projeto para uma Psicologia Científica. (1895). ESB, vol. I, Rio de Janeiro: Imago; 1996a.

Obras completas. A interpretação dos sonhos. (1900). ESB, vol. IV, Rio de Janeiro: Imago; 1996b.

Obras completas. As teorias Sexuais infantis (1908). ESB, vol. IX, Rio de Janeiro: Imago; 1996c. 
. Obras completas. Totem e Tabu (1913). ESB, vol. XIII, Rio de Janeiro: Imago; 1996d.

Obras completas. Artigos sobre a metapsicologia (1915). ESB, vol. XXII, Rio de Janeiro: Imago; 1996e.

Obras completas. Além do princípio do prazer (1920). ESB, vol. XVIII, Rio de Janeiro: Imago; $1996 \mathrm{f}$.

- Obras completas. A organização genital infantil: uma interpolação na teoria da sexualidade. (1923). ESB, vol. XIX, Rio de Janeiro: Imago; 1996g.

Obras completas. Algumas conseqüências psiquicas da distinção anatômica entre os sexos. (1925). ESB, vol. XIX, Rio de Janeiro: Imago; 1996h.

Obras completas. A sexualidade feminina. (1931). ESB, vol. XXI, Rio de Janeiro: Imago; 1996i.

- Obras completas. Novas conferências introdutórias sobre a Psicanálise. A Feminilidade. (1932). ESB, vol. XXII, Rio de Janeiro: Imago; 1996j.

Obras completas. Análise terminável e interminável. (1937). ESB, vol. XXIII, Rio de Janeiro: Imago; 1996k.

Obras completas. A questão da análise leiga: conversações com uma pessoa imparcial. (1926). ESB, vol. XX, Rio de Janeiro: Imago; 1996 I.

Gonçalves N. Posição feminina e gozo suplementar. In: Forbes J. (org). Psicanálise: problemas ao feminino. Campinas: Papirus; 1996.

Heilborn ML De que gênero estamos falando? Sexualidade, Gênero e Sociedade. 1994; Ano 1(2).

Kaufmann $P$ (ed). Dicionário Enciclopédico de psicanálise: 0 legado de FREUD e LACAN. Rio de Janeiro: Jorge Zahar Ed; 1996.

Knauth D R. Subjetividade feminina e soropositividade. In: Barbosa R, Parker R (orgs). Sexualidades Brasileiras: direitos, identidades e poder. Rio de Janeiro: IMS/ UERJ; São Paulo: Ed. 34; 1999. p.121136.

Lacan, J. O seminário - Livro 3: As Psicoses. (1955-1958). Rio de Janeiro: Jorge Zahar; 1996. 
O Seminário- Livro 5: As formaçōes do Inconsciente (19571958) Rio de Janeiro: Jorge Zahar Editor; 1999.

O Seminário- Livro 7: A Ética da Psicanálise. (1959-1960) Rio de Janeiro: Jorge Zahar Editor; 1997a.

O Seminário- Livro 11. Os quatro conceitos fundamentais da psicanálise. (1964) Rio de Janeiro: Jorge Zahar Editor; 1979.

O Seminário- Livro 17: O avesso da psicanálise. (1969-1970) Rio de Janeiro: Jorge Zahar Editor; 1992.

. O Seminário - Livro 20 : Mais, ainda.(1972-1973). Rio de Janeiro: Jorge Zahar Editor; 1985.

Le Seminaire X :"L'anolisse" . (1963). inédito no Brasil. Publicação Interna da Associação Freudiana Internacional. Recife; $1997 b$. $1998 a$.

Escritos. (1901-1981). Rio de Janeiro: Jorge Zahar Editores,

- Subversão do sujeito e dialética do desejo no inconsciente freudiano. In: Escritos. Rio de Janeiro: Jorge Zahar Editor; 1998b.

Posição do Inconsciente. In: Escritos. Rio de Janeiro: Jorge Zahar Editor; 1998c.

A instância da letra no inconsciente ou a razão depois de Freud. In: Escritos. Rio de Janeiro: Jorge Zahar Editor; 1998d.

. O estádio do espelho como formador da função do eu tal como nos é revelada na experiência analitica. In: Escritos. Rio de Janeiro: Jorge Zahar Editor; 1998e.

Observação sobre o relatório de Daniel Lagache: "Psicanálise e estrutura da personalidade". In: Escritos. Rio de Janeiro: Jorge Zahar Editor; 1998 f.

Psicanálise e Medicina (1966). Tradução de Luiz de Souza Dantas Forbes para uso interno da Biblioteca Freudiana Brasileira.

Landroni MAS. Aids e gravidez: desafios para o cuidado nos Serviços de Saúde. São Paulo; 2004. [Dissertação de mestrado - Faculdade de Saúde Pública da USP].

Laplanche e Pontalis. Vocabulário da Psicanálise. São Paulo: Martins Fontes; 1992. 
Leite MP. Psicanálise Lacaniana: cinco seminários para analistas kleinianos. Sāo Paulo: lluminuras; 2000.

Leite MP. O homem supérfluo e o pai necessário. In: Forbes $J$ (org). Psicanálise: problemas ao feminino. Campinas: Papirus; 1996.

Louro GL. Gênero, história e educação: construção e desconstrução. Educação e Realidade. 1995; 20: 101- 132.

Mckinney M, Mcspirit S, Pomeroy C. Prenatal HIV infection practices in a low seroprevalence state. Aids Educational and Prevention. 2000; 12: 252262.

Marques H, Latorre M, Della Negra M, Pluciennnik A, Salomão M. Falhas na identificação da infecção pelo HIV durante a gravidez em São Paulo, SP em 1998. Rev. Saúde Pública. 2002; 36:385-392.

Morel G. Três análises do feminino: Seminários. In: Forbes J (org). Psicanálise: problemas ao feminino. Campinas: Papirus; 1996.

Meré-Rouco J. Sexualidade e mudanças de comportamentos: uma estratégia lúdica de prevenção da Aids. In: Heilborn $M L$ (org). Sexualidade: O olhar das ciências sociais. Rio de Janeiro: Jorge Zahar Ed.; 1999. p. 175- 1999.

Mesquita $F$, Souza $C$ (orgs). DST/Aids. A nova cara da luta contra a epidemia na cidade de São Paulo. São Paulo: Secretaria Municipal de Saúde. Prefeitura Municipal SP. Abril; 2003.

Ministério da Saúde. Aids: Boletim Epidemiológico. Brasilia (DF); 2003. Ano XVII. No1. Jan- Dez.

Ministério da Saúde. Coordenação Nacional de DST e Aids. Guia de tratamento: recomendaçōes para a profilaxia da transmissão materno-infantil do HIV e terapia anti-retroviral em gestantes. Brasilia (DF); 2001.

Ministério da Saúde. Secretaria de vigilância em saúde. Programa nacional de DST e Aids. Recomendaçōes para profilaxia da Transmissão vertical do HIV e terapia anti-retroviral em gestantes. Brasilia (DF); 2004.

Mitka M. MTCT-Plus program has two goals: end maternal HIV transmission and treat mothers. JAMA. 2002; 288:153-154.

Nasio JD. Cinco lições sobre a Teoria de Jacques Lacan. Rio de Janeiro: Jorge Zahar Ed.; 1993. 
Nogueira, S. et al. Successfuf prevention of HIV Transmission from Mother to infant in Brazil using a multidisciplinary team approach. The Brazilian Journal of Infectious Diseases. 2001; 5: 78-86.

O'leary S, Cheney B. A Tripla ameaça: mulheres e Aids. Dossiê Panos. Rio de Janeiro: ABIA. Recife: SOS Corpo. London: Panos Institute Ltda; 1993.

Paiva V. Mulheres e Aids: desafios para os serviços de saúde. São Paulo, 27 de Julho de 2001. Enhacing Care Iniciative (ECl) (in mimeo)

Paiva $V$ et al. Sem direito de amar? A vontade de ter filhos entre homens (e mulheres) vivendo com o HIV. Psicologia USP. 2002; 13:105-133.

Prates A L. Feminilidade e experiência psicanalitica. São Paulo: Hacker Editores; 2001.

Quinet A. As 4+1 condições da análise. Rio de Janeiro: Jorge Zahar Editor; 1991.

Rabinovich D. Uma histeria desmelancolizada. In: IRMA. Rio de Janeiro: Jorge Zahar Editor; 1989.

Ramos $M$ et al. Prevention of Mother-to-child transmission of HIV: compliance with the recommendations of the Brazilian national STD/Aids control program for prenatal and perinatal HIV testing in Porto Alegre, Brazil. Aids and Behavior. 2002; 6

Reis AOA. Análise metafórico-metonímica do processo de construção do pensamento da saúde pública acerca da adolescente grávida: os anos 60. Cad. de Saúde Públ. 1998; 14 (supl.1):115-123.

Rodrigues GV. Nem o sol, nem a morte podem ser olhados de frente. In: Moura MD (org). Psicanálise e Hospital. $2^{\text {a }}$ ed. Rio de Janeiro: Revinter; 2000.

Rosenfeld A et al. Where is the M in MTCT? The Broader Issues in Motherto-child transmission of HIV. American Public Health Association. 2001; 91:703-704.

Salmon K. Preventing MTCT in HIV: What cost in developing countries? Inpharma Weekly. 2002; 1352:5-6.

Santos N. As mulheres e suas decisões reprodutivas, diante da epidemia de HIVIAids. São Paulo; 2002. [Tese de Doutorado Faculdade de Saúde Pública da Universidade de São Paulo]. 
Santos NJS, Buchalla CM, Bugammelli L, Garcia S e Paiva V. Mulheres HIV positivas, reprodução e sexualidade. Revista de Saúde Pública.2002; 36 (supl.4): 4-11.

Santos NJS, Ventura-Filipe E, Paiva V. HIV positive women, reproduction and sexuality in São Paulo, Brazil. Reproductive Health Matter. 1998; 6:31-41.

Schermann E. Relendo o caso Dora. A histeria: o saber e a verdade na direção do tratamento. Stylus. 2003: 159-170.

Scott J. Gênero: uma categoria útil para a análise histórica. Trad. Dabat $L$, Ávila M B. Recife: SOS-Corpo, 1991;16: 5-22. Publicado também em: Educação e Realidade. Porto Alegre. 1995; 20:71-99.

Secretaria Municipal de Saúde de São Paulo. Área temática DST/Aids. Boletim Epidemiológico de Aids do Município de São Paulo. São Paulo: Prefeitura Municipal de São Paulo, 2003. Ano VII. N7. Dez.

Segurado $\mathrm{A}$ et al. The care of women living with HIVIAids in São Paulo, Brazil: Identifying Demands for Enhancement. 2001; São Paulo. in mimeo.

Segre M, Ferraz FC. O conceito de saúde. Rev. Saúde Pública. 1997; 31 (5): 538-542.

Siegel $\mathrm{K}$ et al. Factors associated with HIV-infected women's use or intention to use AZT during pregnancy. Aids Educational and Prevention. 2001; 13: 189-206.

Spink MJ (org). Práticas discursivas e produção de sentidos no cotidiano: aproximações teórico-metodológicas. São Paulo: Cortez; 2000.

Spink MJ, Medrado B. Produção de sentidos no cotidiano: uma abordagem teórico-metodológica para análise das práticas discursivas. In: Spink MJ (org). Práticas discursivas e produção de sentidos no cotidiano: aproximações teórico-metodológicas. São Paulo: Cortez; 2000.

Spink MJ, Lima H. Rigor e visibilidade: explicitação dos passos da interpretação. In: Spink MJ (org). Práticas discursivas e produção de sentidos no cotidiano: aproximações teórico-metodológicas. São Paulo: Cortez; 2000.

Soifer R. Psicologia da gravidez, parto e puerpério. Porto Alegre: Artes Médicas; 1980. 
Sowell RL et al. Factors influencing intent to get pregnant in HIV-infected women living in the southern USA. Aids Care. 2002; 14:181-191.

Szejer M. Palavras para nascer: a escuta psicanalítica na maternidade. São Paulo: Casa do Psicólogo; 1999.

Tanaka ACD, Alvarenga AT. Tecnologia e medicalização na concepção e anticoncepção. In: Galvão L, Diaz J (orgs). Saúde Sexual e reprodutiva no Brasil. São Paulo: Hucitec; 1999.

Tess BHC. Risk factors for mother-to-infant transmission of HIV-1: a colaborative study in São Paulo, Brazil. London; 1997. [Thesis submitted to the Faculty of Medicine of the University of London for the degree of Doctor of Philosophy. London School of Hygiene and Tropical Medicine].

Thorne C, Newell M. Prevention of mother-to-child transmission of HIV infection. Current Opinion in Infectious Diseases. 2004; 17: 247-252.

UNAIDS. 2004 Report on the global Aids epidemic: $4^{\text {th }}$ global report. Geneva: WHO Library Cataloguing-in-publication data; 2004.

Ventura-Filipe E.M et al. Risk perception and counselling among HIV-positive women in São Paulo, Brazil. International Journal of STD\&Aids. 2000; 11: 112-114.

Vermelho L, Silva L, Costa A. Epidemiologia da Transmissão Vertical do HIV no Brasil. Ministério da Saúde; 1999. Disponível em unw.aids.gov.br

Vermelho L, Barbosa SRH, Nogueira S. Mulheres com Aids: desvendando histórias de risco. Cadernos de Saúde Pública. 1999; 15. Apr-Jun.

Villela W. Saúde Reprodutiva em tempo de Aids: desafios e perspectivas. In: Anais do Seminário Brasil-França. Aids e mulheres; 1997. Nov. Salvador. Brasília: Ministério da Saúde; 1998.

Zizek S. Eles não sabem o que fazem: o sublime objeto da ideologia. Rio de Janeiro: Jorge Zahar Editor; 1992. 
Anexo I

Autorizações para a realização de pesquisa 


\section{Universiduade de São Pãulo}

Faculdade de Saúde Pública

COMITE DE ÉTICA - COEP

Av. Dr. Arnaldo, 715 - CEP 01246-904 - São Paulo - Brasil

Telefones: (55-11) 3066- 7734 - fone/fax (55-11) 3064 -7314 - e-mail: mdgracas@usp.br

\section{Of.COEP/069/03}

09 de abril de 2003

Pelo presente, informo que o Comitê de Ética em Pesquisa da Faculdade de Saúde Pública da Universidade de São Paulo-COEP, analisou e aprovou, em sua $3^{\mathrm{a}} / 03$, realizada em 08.04 .03 , de acordo com os requisitos da Resolução CNS'196/96, o Protocolo de Pesquisa n. ${ }^{\circ}$ 951, intitulado: "QUANDO A VIDA PEDE PASSAGEM: ABORDANDO A QUESTÃO DA GRAVIDEZ E DA MATERNIDADE EM MULHERES VIVENDO COM HIV', apresentado pela pesquisadora Karina Franco Zihlmann.

Atenciosamente,

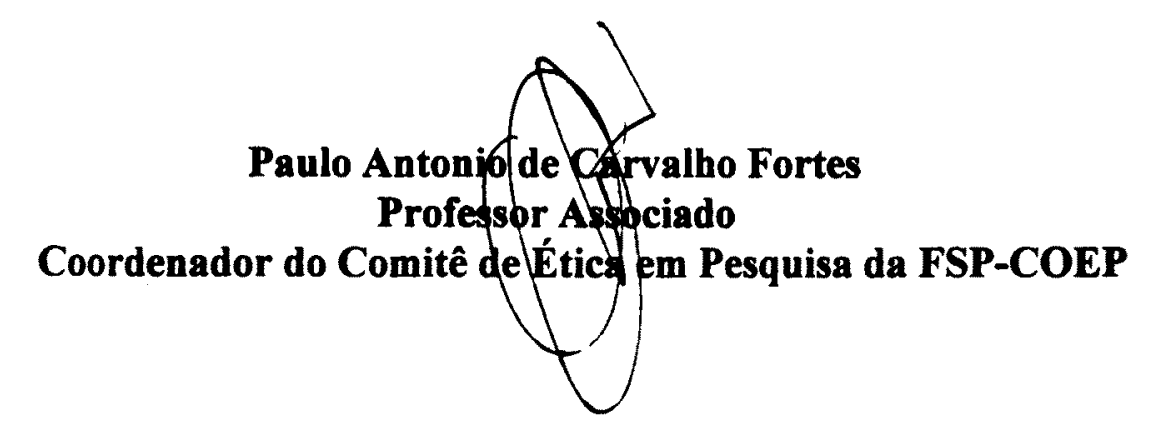




\section{SECRETARIA DE ESTADO DA SAÚDE \\ COORDENACGÃO DOS INSTITUTOS DE PESQUISA \\ INSTITUTO DE INFECTOLOGIA EMILIO RIBAS}

DIVISĨO CIENTIFICA

PROTOCOLO DE PESQUISA NO 37/2003

TÍTULO: "QUANDO A VIDA PEDE PASSAGEM: ABORDANDO A QUESTÃO DA GRAVIDEZ E DA MATERNIDADE EM MULHERES VIVENDO COM HIV" PESQUISADOR RESPONSÁVEL: CARLA MARIA PASQUALI VÁSQUEZ AUTORA PRINCIPAL: KARINA FRANCO ZIHLMANN

\section{AUTORIZAÇÃo PARA INÍCIO dO ESTUdo}

Devidamente aprovado pela Comissão Científica e pelo Comitê de Ética em Pesquisa deste Instituto e regular quanto às informações sobre financiamento do projeto, o protocolo de pesquisa acima está AUTORIZADO para ter início.

Registre-se. Comunique-se.

São Paulo, 19 de fevereiro de 2004.

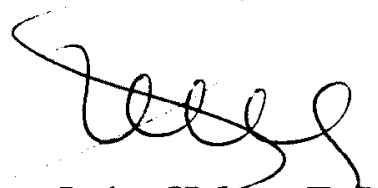

Profa Dra Luiza Hetena F. R Carvalho

Chefe da Seção de Pesquisas e Trabalhos Cientificos 


\section{SECRETARIA DE ESTADDO DÁ SAUUUDE COORDENAÇÃO DOS INSTITUTOS DE PESQUISA INSTITUTO DE INFECTOLOGIA EMILIO RIBAS DIVSÃO CIENTÍFICA}

PROTOCOLO PESQUISA N. ${ }^{\circ} 37 / 2003$

TÍTULO: "QUANDO A VIDA PEDE PASSAGEM: ABORDANDO A QUESTÃO DA GRAVIDEZ E DA MATERNIDADE EM MULHERES VIVENDO COM HIV"

PESQUISADOR RESPONSÁVEL: CARLA MARIA PASQUAREL VAZQUEZ AUTORA PRINCIPAL: KARINA FRANCO ZIHLMANN

\section{COMISSÃO CIENTÍFICA}

Parecer C.C. $n^{\circ} 105 / 03$

A Comissão Científica em 29 de agosto de 2003, em conformidade com o parecer do relator, analisando o protocolo de pesquisa supra mencionado, considera-o aprovado.

São Paulo, 29 de agosto de 2003.

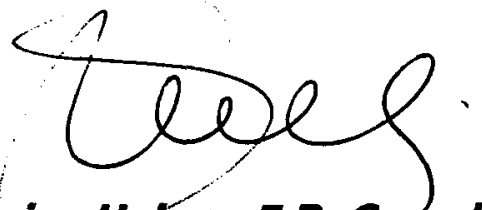

Profa. Dra. Luiza Heféna F.R. Carvalho

Presidente da Comissão Científica 


\section{AVAIDS}

Ao

Comitê de Ética do I.I.R.

\section{DECLARAÇÃO}

Declaramos que a senhora Karina Franco Zihlmann portadora do RG. N²2.792.44-07, foi autorizada pela presidente desta entidade a realizar pesquisa de Mestrado intitulada: "Quando a vida pede passagem", abordando a questão da gravidez e da maternidade em mulheres vivendo com HIV/AIDS.

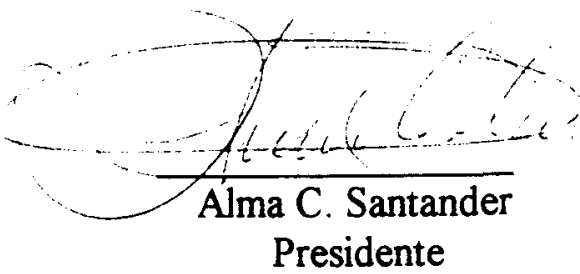




\section{Anexo II}

\section{Roteiro Temático}

Nome da mãe/ codinome:

Idade:

Naturalidade:

Estado civil:

Renda pessoal/ familiar:

Tempo de relação:

$N^{2}$ de filhos: Pré HIV:

Pós HIV:

Grávida (semanas):

Escolaridade da mãe:

Prof. da mãe:

Escolaridade do companheiro:

Estado sorológico do companheiro:

Prof. do companheiro:

Instituição onde faz tratamento:

Tempo de tratamento:

Tipo de tratamento: antes da gravidez

$\mathrm{Na}$ gravidez

atual

Opinião sobre a instituição e o tratamento:

Como conheceu a Avaids?

Tempo de freq. na ONG:

Opinião sobre a ONG:

Descoberta do HIV: Como se deu, reação pessoal, a quem pediu informações e/ou ajuda, como foi a reação das pessoas

HIV e a gravidez:

- Você recebeu orientação sobre o teste de HIV no pré-natal ou anteriormente?

- Você recebeu orientação após o resultado do HIV no pré-natal ou anteriormente?

- Você tem alguma dúvida quanto aos termos usados cotidianamente como "CD4, Carga Viral, mutação, genotipagem, anti-retrovirais, adesão", etc? Sabe qual sua situação atual de CD4 e CV?

- Fez pré-natal? Onde? Iniciou em que semana da gestação?

- Compareceu a quantas consultas? Como foram as consultas? Ficou com dúvidas? Como é sua relação com o ginecologista e/ou obstetra?

- Foi orientada quanto à prevenção da Transmissão para o bebê? 
- Teve o bebê na maternidade onde fez o pré-natal? Tomou a medicação AZT no pré, durante o parto e para o bebê?

- Como foi o parto? E o pós-parto? (investigar relação com equipe e suporte familiar)

- Como alimentou o bebê? (questão da amamentação)

- Qual a expectativa quanto ao risco de contaminação do bebê? (investigar se foi orientada e o impacto dessas informações e do tempo de espera). E se ele for infectado?

- O que é para você "ter um filho"?

- O que é para você "ser mãe" ?

- Como é para você ser mãe e ser portadora do HIV?

- Você considera a gravidez de uma mulher portadora do HIV diferente de uma mulher não portadora? Por que?

- Como foi a sua decisão de ter um filho?

- Você acredita que o fato de ser portadora do HIV influenciou na sua decisão de ter filhos? De que maneira?

- Como foi acolhida sua decisão de ter um filho:

- Pelo pai da criança

- Pela sua família

- Pela equipe médica que acompanha no tratamento do HIV

- Pela equipe médica que acompanha (ou acompanhará) sua gravidez?

- O que você acredita que sua decisão de ter um filho pode ter como conseqüências:

- na sua vida pessoal e/ou afetiva

- de seu filho,

- da sua família,

- para a sociedade

- Como você se percebe hoje? (por ser portadora do HIV, mulher e mãe)

- Como acha que seu companheiro a percebe? E seu médico? E sua família? E a sociedade? 
- Você pretende ter outros filhos? Por que e quando? Se não, por que não? Como pretende evitar uma nova gravidez?

- Uso do preservativo e outro método anticoncepcional (Anterior e atual)

- Como você caracteriza sua vida afetivo-sexual? Antes da gravidez, a partir do HIV e atual.

- Associação de palavras:

Filho:

Mãe:

Pai:

Casamento:

Família:

Aids:

HIV:
Cura:

Remédio:

Vida:

Morte:

Medo:

Desejo:

Sonho: 


\section{Termo de Consentimento Livre e Esclarecido}

\section{I- Dados de Identificação do Sujeito da Pesquisa}

Nome do entrevistado:

Documento de Identidade:

Sexo:

Data de nascimento:

Endereço:

№

Apto

Bairro:

Cidade:

Cep: Telefone ( )

II- Dados sobre a Pesquisa

1.Título da Pesquisa: "Quando a vida pede passagem: abordando a questão da gravidez e da maternidade em mulheres vivendo com o HIV"

2. Pesquisador:

3. Cargo/ Função:

4. Inscrição no Conselho Regional:

5. Instituição onde se realiza a pesquisa:

6. Avaliação do Risco da Pesquisa: Isenta por não comportar procedimentos invasivos.

7. Duração da Pesquisa: Aproximadamente 2 anos

\section{III- Registro das explicações do Pesquisador} ao entrevistado sobre a pesquisa

Consignando as seguintes informações:

1. Justificativa e os objetivos da pesquisa; 2 . Procedimentos que serão utilizados e propósitos, incluindo a identificação dos procedimentos que são experimentais; 3. Desconfortos e riscos esperados; 4. Benefícios que poderão ser obtidos; 5 . Procedimentos alternativos que possam ser vantajosos para o indivíduo.

Explicação ao sujeito da pesquisa:

Vocé está sendo convidada a participar de uma pesquisa que tem como título "Quando a vida pede passagem: abordando a questão da gravidez e da maternidade em mulheres vivendo com o HIV". Esta pesquisa busca investigar como as mulheres portadoras HIV vêem a gravidez e a maternidade. Trata-se de uma entrevista com perguntas e pediremos que você responda da maneira mais sincera possível. Estimamos que a entrevista seja de aproximadamente 50 minutos e se necessário poderemos agendar um outro encontro. A entrevista poderá ser gravada e do mesmo modo não haverá identificação de seu nome na transcrição da fita. O uso desta fita ficará restrito aos propósitos desta pesquisa. Você poderá escolher um nome fictício 
para constar da divulgação dos dados. As informações que você fornecer não serão associadas ao seu nome, portanto não haverá possibilidade de que você venha a ser identificada. Seu tratamento nesta instituição prosseguirá independentemente dessa pesquisa e não existe nenhum risco para você neste estudo e caso você decida não participar do mesmo, ficará a seu critério interromper o processo assim que achar necessário, sem qualquer prejuizo ao seu atendimento nesta instituição. Se você desejar, poderá ter acesso às informações desse estudo. Suas respostas, junto com a dos outros participantes do estudo, poderão ajudar profissionais da saúde a desempenhar melhor suas funçōes. Se você concordar com essas condiçōes, por favor assine este termo de consentimento e receberá uma cópia do mesmo.

IV- Esclarecimentos dados pelo pesquisador sobre garantias do sujeito da pesquisa

1- Acesso, a qualquer tempo, às demais informações que julgar necessárias.

2- Liberdade de retirar seu consentimento a qualquer momento e deixar de participar do estudo, sem que isto traga prejuízo à continuidade da assistência

3- Salvaguarda da confidencialidade, sigilo e privacidade

V- Informaçōes de Nomes, endereços e telefones dos responsáveis pelo acompanhamento da pesquisa, para contato em caso de quaisquer esclarecimentos

Pesquisadora Karina Franco Zihlmann

Faculdade de Saúde Pública USP: 3081-2451

VI- Consentimento Livre e esclarecido:

Declaro que, após convenientemente esclarecido pelo pesquisador e ter entendido o que me foi explicado, consinto em participar desta Pesquisa.

São Paulo, de de

Assinatura do Sujeito

Assinatura do Pesquisador

CRP 06/ 60489 


\section{Anexo IV}

Tabela 1: Características sócio-demográficas das entrevistadas. São Paulo, SP, 2003.

\begin{tabular}{|c|c|c|c|}
\hline Varíivel $(n=15)$ & Categorias & $\bar{N}$ & $\%$ \\
\hline Idade (anos) & $\begin{array}{l}18-22 \\
23-27 \\
28-32 \\
33-37\end{array}$ & $\begin{array}{l}2 \\
4 \\
5 \\
4\end{array}$ & $\begin{array}{l}13.3 \\
26,6 \\
33,5 \\
26,6 \\
\end{array}$ \\
\hline Estado civil & $\begin{array}{c}\text { Solteira } \\
\text { Casada } \\
\text { Divorciada/separada } \\
\text { Uniāo estável } \\
\text { viúva }\end{array}$ & $\begin{array}{l}1 \\
- \\
2 \\
9 \\
3\end{array}$ & $\begin{array}{c}6,7 \\
- \\
13,3 \\
60,0 \\
20,0 \\
\end{array}$ \\
\hline Tempo de relaçăo (anos) & $\begin{array}{c}<1 \text { ano } \\
1-5 \text { anos } \\
>5 \text { anos }\end{array}$ & $\begin{array}{l}2 \\
7 \\
6\end{array}$ & $\begin{array}{l}13.3 \\
46.7 \\
40.0 \\
\end{array}$ \\
\hline Naturalidade & $\begin{array}{l}\text { Regiăo sudeste } \\
\text { Regiăo nondeste } \\
\text { Regix̌o sul }\end{array}$ & $\begin{array}{c}10 \\
4 \\
1\end{array}$ & $\begin{array}{r}66,7 \\
26,6 \\
6,7\end{array}$ \\
\hline $\begin{array}{l}\text { Renda Pessoal Bruta } \\
\text { (SM=Salános minimos) }\end{array}$ & $\begin{array}{c}\text { Sem renda pessoal } \\
<1 \mathrm{SM} \\
21-3 \mathrm{SM} \\
23-10 \mathrm{SM} \\
\geq 10 \mathrm{SM}\end{array}$ & $\begin{array}{l}5 \\
3 \\
5 \\
1 \\
1\end{array}$ & $\begin{array}{c}33,3 \\
20,0 \\
33,3 \\
6,7 \\
6,7\end{array}$ \\
\hline $\begin{array}{l}\text { Renda familiar Bruta } \\
\text { (SM=Salários mínimos) }\end{array}$ & $\begin{array}{c}<1 S M \\
21-3 \mathrm{SM} \\
23-10 \mathrm{SM} \\
210 \mathrm{SM} \\
\end{array}$ & $\begin{array}{l}3 \\
9 \\
1 \\
2 \\
\end{array}$ & $\begin{array}{r}20,0 \\
60,0 \\
6,7 \\
13,3 \\
\end{array}$ \\
\hline Escolaridade da măe & $\begin{array}{l}1^{\circ} \text { grau incompleto } \\
1^{\circ} \text { grau completo } \\
2^{\circ} \text { grau incompleto } \\
2^{\circ} \text { grau completo } \\
\text { superior }\end{array}$ & $\begin{array}{l}6 \\
2 \\
3 \\
3 \\
1\end{array}$ & $\begin{array}{c}40,0 \\
13,3 \\
20,0 \\
20,0 \\
6,7 \\
\end{array}$ \\
\hline Profiss 10 da măe & $\begin{array}{c}\text { Do lar } \\
\text { Atendente/recepcionista } \\
\text { Profissional autônomo } \\
\text { Professora } \\
\text { Bancária } \\
\text { Profissional do sexo }\end{array}$ & $\begin{array}{l}3 \\
4 \\
4 \\
1 \\
1 \\
2\end{array}$ & $\begin{array}{c}20,0 \\
26,6 \\
26,6 \\
6,7 \\
6,7 \\
13,4\end{array}$ \\
\hline Escolaridade do companheiro & $\begin{array}{c}1^{\circ} \text { grau incompleto } \\
1^{\circ} \text { grau completo } \\
2^{\circ} \text { grau incompleto } \\
2^{\circ} \text { grau completo } \\
\text { superior } \\
\text { N1\%o sabe informar }\end{array}$ & $\begin{array}{l}3 \\
4 \\
1 \\
1 \\
- \\
6\end{array}$ & $\begin{array}{c}20,0 \\
26,6 \\
6,7 \\
6,7 \\
- \\
40,0\end{array}$ \\
\hline Profissăo do companheiro & $\begin{array}{c}\text { Nâ sabe informar } \\
\text { Técnico Mecânico/eletrônica } \\
\text { Profissional autônomo } \\
\text { bancínio }\end{array}$ & $\begin{array}{l}4 \\
2 \\
8 \\
1\end{array}$ & $\begin{array}{r}26,6 \\
13,3 \\
53,4 \\
6,7\end{array}$ \\
\hline Estado sorologico do companheiro & $\begin{array}{c}\text { Nảo sabe informar ou nåo fez exame } \\
\text { Positivo } \\
\text { Negativo }\end{array}$ & $\begin{array}{l}5 \\
7 \\
3\end{array}$ & $\begin{array}{l}33,3 \\
46,7 \\
20,0\end{array}$ \\
\hline Tempo de conhecimento do HIV & $\begin{array}{c}<1 \text { ano } \\
21-3 \text { anos } \\
23-10 \text { anos }\end{array}$ & $\begin{array}{c}1 \\
2 \\
12 \\
\end{array}$ & $\begin{array}{l}6,7 \\
13,3 \\
80,0 \\
\end{array}$ \\
\hline Tempo de tratamento & $\begin{array}{c}<1 \text { ano } \\
21-3 \text { anos } \\
23-10 \text { anos }\end{array}$ & $\begin{array}{l}1 \\
5 \\
9\end{array}$ & $\begin{array}{r}6,7 \\
33,3 \\
60,0\end{array}$ \\
\hline $\mathbf{N}^{\top}$ de filhos ${ }^{*}$ & $\begin{array}{l}\text { Grávidas } \\
\text { Imes - } 1 \text { ano } \\
21 \text { ano a } 5 \text { anos } \\
25 \text { anos a } 10 \text { anos } \\
210 \text { anos }\end{array}$ & $\begin{array}{c}2 \\
11 \\
6 \\
5 \\
7\end{array}$ & $\begin{array}{l}13,3 \\
73,3 \\
40,0 \\
33,3 \\
46,7\end{array}$ \\
\hline
\end{tabular}

Por profissional autônomo compreendemos cabeleireiro, artesā, feirante, entre outros.

"A somatória é major que $100 \%$ pois se trata do número total de filhos das entrevistadas. 


\section{Glossário'}

- Aids:

O termo "Aids" é uma sigla proveniente da língua inglesa e se refere a Acquired Immunodeficiency Syndrome e em português é conhecida como "Sida" ou Sindrome de Imunodeficiência Adquirida. A Aids é uma doença do sistema imunitário causada pelo retrovírus HIV e se caracteriza por astenia, perda de peso acentuado e uma drástica diminuição no número de linfócitos $T$ auxiliadores (CD4). O organismo da pessoa que possui o HIV torna-se incapaz de produzir anticorpos em resposta aos antigenos mais comuns, tomando-se suscetivel a diversos organismos oportunistas ou a certos casos raros de Câncer (Sarcoma de Kaposi, linfomas, entre outros). A infecção oportunista mais comum é a pneumonia provocada pelo Pneumocystis carinii, sendo também freqüentes, casos de toxoplasmose, criptococose e infecções provocadas por citomegalovirus.

A sigla "Sida" se refere a uma sindrome, ou seja, uma combinação de sinais fisicos e sintomas. "imunodeficiência" diz respeito ao fato de que o sistema imunológico está debilitado, enfraquecido, deficiente ou incapacitado de exercer as funçoes de proteger o organismo contra invasores de qualquer natureza. 0 termo "adquirida" diz respeito ao fato de que o virus foi em algum momento introduzido no organismo. A Síndrome da imunodeficiência adquirida é, portanto, a perda ou a diminuição acentuada da capacidade do sistema imunolbgico de defender o próprio organismo, devido a açăo do HIV. Uma pessoa pode ser portadora do HIV e não ter Aids, pois esta só se caracteriza quando o sistema imunológico estiver debilitado a tal ponto em que se dá o surgimento das infecçőes ou doenças oportunistas.

\section{- Acting out.}

Segundo Kaufmann (1996), quando um sujeito não consegue se lembrar de um elemento recalcado, ele age por vezes sem saber o que está retomando na forma de uma açăo. Quer ocorra durante uma sessão de análise ou fora dela, um acting out reproduz um clichê ou um roteiro inconsciente e possui uma dimensåo transferencial. $O$ acting out pode se constituir em um apelo, um desafio ou uma réplica, que atestam uma incapacidade de dizer, correspondendo a uma intervenção no real ou significando o que a

\footnotetext{
${ }^{1}$ Nä pretendemos, evidentemente, através desse glossário, esgotar os conceitos abordados nesse trabalho. Temos ciência da complexidade que cada conceito assume, năo apenas em cacta autor referido, mas tamberm no que conceme ao momento em que cada conceito é construido no conjunto da obra dos mesmos. Sendo assim, náo seria possivel, mediante o tipo de trabalho aqui proposto, a explanaçáo que, embora interessante, tomaria por demais complexa e distante de nossos objetivos. Optamos por situar, grosso modo, aspectos dos conceitos que poderiam estar mais diretamente relacionados com o escopo deste trabalho e sugerimos enfaticamente ao leitor que se remeta a dicionários comentados sobre 0 assunto, particularmente o dicionário de Kaufmann (1996), que procura apresentar os conceitos partindo de uma construçáo lógica e cronológica, tanto na obra freudiana, quanto na obra lacaniana.
} 
interpretação deixou de considerar. Representa uma verdade não reconhecida e se situa na fronteira entre a vida real e a cena de ficção. Em um processo de análise, 0 acting out pode perturbar o jogo, ou pode permitir 0 acesso à representação se puder ceder lugar à fala.

\section{- Agalma:}

O dicionário de Kaufmann (1996), trata o termo agalma a partir do grego, que pode ser traduzido como omamento, tesouro, objeto de oferenda aos deuses, ou de modo mais abstrato, como um valor. Esse termo foi usado na conceituação lacaniana como ponto pinô do conceito de objeto causa de desejo ou objeto a.

Lacan situa o termo agalma ao comentar o Banquete de Platão em seu seminário sobre a Transferência. Nesse seminário, ele situa o objeto do desejo como aquele que está carregado de um peso de símbolos e de trocas, que pode ser comparado como a um Sileno, ou um objeto brilhante escondido no interior do personagem que Sócrates representa para Alcebiades. Lacan comenta que Alcebiades é seduzido pelo agalma de Sócrates, pois o próprio Alcebiades havia comparado Sócrates como uma estatueta grotesca de Sileno. Essas estatuetas eram receptáculos, caixas de jóias que, malgrado a grotesca aparência externa, em seu interior escondiam um objeto precioso. Kaufmann comenta que o agalma representa a insistência do desejo naquilo que a demanda de amor comporta de enigmático, ou no que a demanda de amor deve conservar de enigmático para um analista cuja escuta não pode ser regular por um ideal de compreensão totalizante. O termo agalma é útil se for capaz de evocar a irredutibilidade do desejo.

\section{- Castração:}

Nasio (1989) aponta que em psicanálise, o conceito de castração não corresponde à acepção habitual de mutilação dos órgãos sexuais masculinos, mas designa uma experiência psíquica completa, inconscientemente vivida pela criança por volta dos cinco anos de idade. Essa experiência é fundamental para que a determinação da identidade sexual da criança. Nasio ressalta que o aspecto essencial dessa experiência é o reconhecimento da diferença anatômica entre os sexos, o que gera angústia para a criança. Após a constatação da diferença entre os sexos, a criança já não pode manter sua onipotência e terá que aceitar que seu corpo tem limites, além do fato de que embora tenha intensos desejos sexuais em relação à mãe, não poderá jamais concretizar tais desejos. O complexo de castração não se reduz a um momento cronológico do desenvolvimento da sexualidade infantil, pois é de fato, uma experiência inconsciente constantemente renovada ao longo da existência do sujeito. Nasio aponta ainda, que um dos objetivos da experiência analítica é possibilitar que o sujeito adulto se depare novamente com sua experiência infantil e admitir, com dor, que os limites do corpo são mais estreitos do que os limites do desejo. 
No dicionário de Kaufmann (1996), vemos que na teoria lacaniana, a castração corresponde à incapacidade do sujeito de obter no Outro a garantia de gozo, reservada ao pai em sua precedência simbólica junto à mãe (trata-se do acesso de fato do pai à măe). Na formulação lacaniana, a noção de castração explicita o impasse estrutural que a experiência de castração atestará, fundando uma lógica para a questão da sexualidade.

- Complexo de Edipo:

Em Laplanche e Pontalis (1995), vemos que se trata de um conjunto organizado de desejos amorosos e hostis que a criança sente em relação aos pais. Sob a sua forma dita positiva, o complexo apresenta-se como na tragédia grega "Édipo-Rei": desejo de morte do rival que é a personagem do mesmo sexo e desejo sexual pela personagem do sexo oposto. Sob a sua forma negativa, apresenta-se de modo inverso: amor pelo progenitor do mesmo sexo e ódio ciumento ao progenitor do sexo oposto. A princípio, Freud propós que 0 apogeu do complexo de Édipo é vivido entre os trés e os cinco anos de idade, durante a fase fálica e seu declínio se dá com a entrada da criança na fase da latência. $O$ complexo de Édipo é revivido na puberdade e desempenha um papel fundamental na estruturaçăo da personalidade e na orientaçăo do desejo humano.

Por sua vez, Kaufmann (1996) aponta que a teoria lacaniana, desde 1938, promove uma redefiniçăo do Édipo apoiando-se tanto em Freud ("retorno a Freud") quanto na teoria antropológica estrutural de Lévi-Strauss. Lacan radicaliza o corte e a hierarquização entre natureza e cultura e vê na proposta de Lévi-Strauss da estrutura masculinista da "troca de mulheres" como um efeito da Kógica fálica que rege a instituição do humano. Quando Lacan propōe que o inconsciente é estruturado como uma linguagem, o Édipo é construído como um invariante inelutável inscrito no inconsciente.

\section{- Desejo:}

A psicanálise mostrou, segundo Laplanche e Pontalis (1995), a partir do modelo de interpretaçăo freudiana do sonho, que o desejo inconsciente tende a realizar-se restabelecendo, segundo as leis do processo primário, os sinais ligados às primeiras vivências de satisfação.

Kaufmann (1996) aponta que na cultura psicanalítica, literária e filosófica de lingua francesa, o termo désir (desejo) designa o campo de existência do sujeito humano sexuado, em oposiçăo à abordagem biológica do humano que se limita aos comportamentos e aos sistemas de relação. Em Freud, a noçăo de desejo năo ocupa o mesmo lugar que para Lacan. Enquanto Freud o termo "desejo" se articula com um objeto empírico, ou seja, há "desejos", o que se observa pela expressão freudiana Wuscherfüllung ou realização de desejos. Por sua vez, a concepção lacaniana de desejo se dá pela articulação da trilogia "necessidade, demanda e desejo", que aponta a subjetividade humana em contigúidade com a ordem biológica das necessidades da reprodução em sua 
conexão fundamental com a ordem da linguagem. Enquanto para Freud a teoria do desejo se refere à realização espontaneamente alucinatória de seu fim, para Lacan, a teoria do desejo é tomada como falta de seu objeto, o que traz importantes conseqüências para o sujeito.

\section{- Falo:}

Na teoria lacaniana, segundo Nasio (1989), a palavra falo não designa o órgão genital masculino. E o nome de um significante muito particular, diferente de todos os outros significantes, que tem por função significar tudo o que depende da dimensão sexual. O falo não é o significante do gozo, pois o gozo resiste em ser representado. O falo baliza o trajeto do gozo e do desejo (enquanto orientado a um objetivo para satisfazer-se). O falo é o significante que marca e significa cada uma das etapas desse trajeto de gozo: marca a origem do gozo materializado nos orificios erógenos; marca também o obstáculo ao gozo (recalcamento); marca ainda as exteriorizações do gozo sob a forma de sintomas, fantasias ou da ação; e finalmente, marca o limiar para além do qual se descortina o mundo mítico do gozo-do-Outro.

\section{- Gozo:}

Segundo Kaufmann (1996), o campo do gozo não diz respeito ao campo natural biológico, mas sim, "do ponto em que o vivo pactua com a linguagem" (p. 221). No texto "Mais além do princípio do prazer" de 1920, a partir do conceito de repetiçăo, Freud conceitua gozo como um esforço de reencontro, mas que em funçåo da impossibilidade estrutural da linguagem, na repetição, sujeito deparase com uma falha que revela "um objeto para sempre perdido".

Por sua vez, Nasio (1989), ressalta que, embora a palavra gozo evoque a idéia de "volúpia" ou "orgasmo", na teoria lacaniana há uma distinçăo entre prazer o gozo. A teoria do gozo proposta por Lacan é uma construção complexa, que distingue trés modos de gozar. Lacan designa pelo termo gozo, trés estados caracterizados do gozar: o gozo fálico, o mais-de-gozar e o gozo-do-Outro. O gozo fálico corresponderia à energia dissipada durante a descarga parcial, com alivio incompleto da tensão inconsciente. O falo funciona como uma comporta (metaforicamente falando) que regula a parcela de gozo que sai (descarga) e a que permanece dentro do sistema inconsciente e nesse sentido a função fálica consiste em abrir e fechar o acesso do gozo ao exterior. O mais-de-gozar é outra categoria de gozo que corresponde à parcela de gozo que permanece retida no interior do sistema psíquico. Trata-se, portanto, de um excedente que aumenta constantemente a tensão interna. Esse gozo residual permanece profundamente ancorado nas zonas erógenas e orificiais do corpo (boca, ânus, vagina, canal peniano, etc). O gozo-do-Outro é uma categoria hipotética que corresponderia à situação de descarga total das tensōes inconscientes. 0 sujeito supøe que o Outro é dotado dessa capacidade de descarga completa, ou seja, de um estado ideal de felicidade absoluta e impossível. A imagem mítica do incesto considerada como a realização consumada do desejo é 
representada por um gozo supremo ou gozo-do-Outro, ou ainda como gozo absoluto.

- HIV :

O agente causador da Aids é o Vírus da Imunodeficiência Humana. Esse vírus é mais conhecido pela sua sigla em inglês "HIV", que significa Human Immunodeficiency Virus. O HIV infecta e destrói principalmente as células do sistema imunológico e está em constante processo de mutação, o que dificulta o desenvolvimento de drogas que possam erradicá-lo. Os vírus são agentes infecciosos que podem ser observados em microscópios eletrônicos (são invisiveis a olho nu) e só conseguem sobreviver e proliferar quando instalados em uma célula hospedeira. O HIV é um vírus da familia dos lentivirus, citopáticos, năo oncogênicos, o que significa que se trata de um virus de ação lenta, que destrói a sua célula hospedeira e não provoca câncer.

O HIV é chamado de retrovirus porque possui uma enzima chamada de transcriptase reversa. Esta enzima permite que ele transcreva suas informações genéticas contidas em uma cadeia simples de RNA (o material genético do virus é chamado de RNA viral) para uma cadeia dupla de DNA viral. Outra enzima, chamada de integrase, faz com que o vírus seja capaz de se introduzir no DNA da célula infectada e obrigá-la a produzir réplicas dele. Esse processo se repete inúmeras vezes, e no caso do HIV, com baixa fidelidade no processo de replicação, o que favorece 0 aparecimento de mutações virais.

- Metáfora:

Podemos tomar o termo metáfora a partir de Kaufmann (1996) que aponta que, a principio, ele se refere classicamente a "figuras de estilo" que modificam o sentido das palavras, omamentando o discurso com um sentido que vai para alem da palavra em si. Lacan retoma as noçőes de condensação e deslocamento propostas por Freud no texto "A interpretação dos sonhos" de 1900 e situa assim, a noção de metáfora como um conceito fundamental para designar a relação do sujeito castrado e sexuado da linguagem. A partir da Lingüística e baseado nos trabalhos de Saussure, Benveniste e Jakobson, Lacan mostrou que as formações do inconsciente se manifestam segundo uma estrutura formal. O discurso é orientado segundo dois eixos espaço-temporais, sendo eles, o eixo paradigmático (eixo da seleção, eixo do léxico, do tesouro da linguagem, da substituição e da sincronia sendo, portanto, tomado como o eixo da metáfora) e o eixo sintagmático (o eixo da combinação, da contigüidade e da diacronia, sendo, portanto, o eixo da metonimia). Kaufmann aponta que as operaçōes metáforo-metonímicas explicarão a extensão da metáfora paterna à alienação do sujeito no campo do Outro (Che vuoi?), instituindo a dialética do desejo.

Lacan define metáfora como "a implantação numa cadeia significante, pela qual aquele que ele suplanta cai na categoria de significado e como significante latente perpetua aí o intervalo em que uma outra cadeia significante pode ter 
entrado". Sendo assim, a metáfora se caracteriza literalmente por uma substituição significante e promove a idéia fundamental da supremacia do significante, pois Lacan empenhou-se em ampliar a noção de metáfora, aplicando-a não apenas ao funcionamento dos processos inconscientes, mas também à própria articulação ao campo inconsciente do sujeito falante e sexuado (Kaufmann 1996, p. 333)

\section{- Metonimia:}

A metonimia se define etimologicamente como uma mudança de nome. Um termo é designado por um outro termo que não aquele que o designa habitualmente. Kaufmann (1996) aponta que a metonimia está fundamentalmente articulada com o desejo, na medida em que a metáfora paterna e o acesso do falo como estatuto do significante, permitem ao sujeito 0 acesso ao desejo mediado pela linguagem. $O$ desejo remete o sujeito ao impossivel da plenitude, pois o sujeito se vê enredado pela busca de objetos substitutivos que o mobilizam em lugar do objeto fundante (a mãe). $O$ processo da metonímia projeta o sujeito sobre o eixo sintagmático de seu discurso, fazendo com que ele, em lugar de ser o falo, o sujeito vai tentar ter o falo. $O$ desejo é constantemente sustentado e relançado pelo significante, em razão da metáfora fundadora e pelo recalcamento originário. O espaço metafórico força o sujeito a se situar no eixo temporal, sendo que a partir da metáfora fundante, o significado do significante, em última inståncia, é o desejo. $O$ processo metonímico consiste entåo, por levar um significante para outro significante.

\section{- Objeto a:}

Nasio (1989) refere que o objeto a, no que ele engendra da sua relação com o objeto de desejo, nada tem a ver com uma parte fisica do corpo, sendo antes de tudo, uma produção da dupla măe-bebê. Ele não pertence nem ao sujeito e nem ao outro. E uma condição imaginária (imagem pregnante) e condição simbólica (da dupla demanda permeada pela Linguagem). Em termos estritos, o objeto a é o furo, o gozo enigmático e inominável, um excesso que insiste em se fazer presente. Como resultado dessa plasticidade, tal objeto pode assumir todas as imagens visuais, corporais, auditivas e táteis do encontro duplamente desejante (e duplamente insatisfeito) da relação entre a criança e a mãe (entre o sujeito e a mãe enquanto representante do Outro).

\section{- Outro:}

A partir de Kaufmann (1996), a concepçăo lacaniana do significante implica uma relação estrutural entre o desejo e o "grande Outro". Essa noção de grande Outro é concebida como um espaço aberto de significantes que o sujeito encontra desde seu ingresso no mundo; trata-se da realidade discursiva de que Lacan fala no Seminário 20: o conjunto dos termos que constituem esse espaço remete sempre a outros. Esse conjunto de objetos participam da dimensão simbólica margeada pelo imaginário. A instância imaginária do eu se forja em 
função do que faz falta no Outro. Lacan formaliza esse conceito através do grafo do desejo (no Seminário 5 "As Formações do Inconsciente" de 1957-1958; em "Subversão do sujeito e diakética do desejo" nos Escritos de Lacan 1998b).

\section{- Passagem ao ato:}

Kaufmann (1996) aponta que em Psiquiatria, o termo passagem ao ato serve para designar a violência ou a brusquidão de diversas condutas que curtocircuitam a vida mental e precipitam o sujeito numa ação: agressão, suicídio, comportamento perverso, delito, entre outros. Para Lacan, esse termo pode ser identificado como uma saída de cena em que, como uma defenestração ou um salto no vazio, o sujeito se reduz a um objeto excluido ou rejeitado. Isso não impede que haja entăo uma atuação do desejo do Outro. Nesse caso, porém, o ato não seria "aquilo que quer dizer" e corresponderia a uma ruptura do quadro da fantasia e a uma expulsão do sujeito.

- Pulsão:

O termo "pulsão" é definido por Laplanche e Pontalis (1995) como um processo dinâmico que consiste numa pressão ou força (carga energética) que faz o organismo tender para um objetivo. Para Freud, uma pulsảo tem como fonte uma excitaçăo corporal (estado de tensão); o seu objetivo ou meta é suprimir o estado de tensão que reina na fonte pulsional; é no objeto ou graças a ele que a pulsăo pode atingir a sua meta. Em Freud encontramos os termos Instinkt e Trieb em acepções nitidamente distintas. Quando Freud fala de Instinkt, qualifica um comportamento animal fixado por hereditariedade, característico da espécie, pré-formado no seu desenvolvimento e adaptado ao seu objetivo. Quando ele se refere a Trieb, termo de raiz germånica, conserva a nuançe de impulsăo (treiben=impelir), o que coloca a ênfase menos em uma finalidade definida do que numa orientaçăo geral e sublinha o caráter irreprimivel da pressão mais do que a fixidez da meta e do objeto (como se dá com relação ao termo Instinkt). A teoria freudiana das pulsóes é sempre dualista. O primeiro dualismo invocado é o das pulsões sexuais e das pulsóes do ego (ou chamadas de pulsōes de autoconservação). A partir do texto "Além do princípio do prazer" de 1920, Freud contrapōe as pulsões de vida em relaçăo às pulsőes de morte.

Kaufmann (1996) distingue três aspectos da noção de pulsão:

1- Aspecto fisiológico: se considerarmos a pulsăo em sua generalidade, distinguiremos a excitação pulsional da excitação da área reflexa com base em três caracteristicas: tem origem interna, força constante e é impossivel se lhe escapar por açóes de fuga.

2- Aspecto biológico: na auséncia de uma possibilidade de fuga, impõe-se a tarefa de um "controle" das excitaçōes, cujas flutuações se manifestarão pelo automatismo das variações na série prazer-desprazer.

3- Aspecto psicológico ou biopsicológico: "Se, situando-nos de um ponto de vista biológico, considerarmos agora a vida psiquica, o conceito 'pulsão' nos parece como um conceito-limite entre o psíquico e o somático, como 
o representante psíquico das excitações que provém do interior do corpo e chegam ao psiquismo, como uma medida de exigência de trabalho que é imposta ao psiquico em conseqüência de sua ligação com o corpo" (p. 439)

\section{- Significante}

Para Nasio (1989), o significante é uma categoria formal, e não descritiva. Pouco importa o que ele designa (um lapso, um sonho, o relato de um sonho, um detalhe desse relato, um gesto, um som, um silêncio ou uma interpretação do psicanalista, entre outros), pois ele se refere a manifestaçōes que podem ser qualificadas dentro de três critérios não-lingüísticos:

1- O significante é sempre a expressão involuntária de um ser falante. Um gesto qualquer só será significante se for um gesto imprevisto, executado fora de qualquer intencionalidade e saber consciente.

2 - O significante é desprovido de sentido, não significa nada e, portanto, não é passível de ser explicável ou inexplicável. Por exemplo, um sintoma, se tomado como um significante, não invoca nem uma suposiçăo do analisando, nem uma construçăo do psicanalista. $O$ significante é, nada mais que isso.

3 - O significante se articula impreterivelmente com outros significantes. Para Lacan, um significante só é significante para outros significantes.

- TMI:

O termo "Transmissão Materno-Infantil" (TMI) refere-se ao risco que uma mulher gestante, sendo portadora de uma doença infecto-contagiosa, tem de gerar e dar a luz a um bebé com o mesmo quadro infeccioso, além do risco de infecção através da amamentaçăo. As mulheres vivendo com HIVIAids podem transmitir o virus para seus filhos, assim como em uma série de outras doenças infecciosas como sifilis congênita, hepatite $B$, rubéola, HTLV, entre outros.

- Transferência:

O termo transferência designa, segundo Laplanche e Pontalis (1995), o processo pelo qual os desejos inconscientes se atualizam sobre determinados objetos no quadro de um certo tipo de relação estabelecida com eles e, eminentemente, no quadro da relação analítica. Trata-se aqui de uma repetição de protótipos intantis vivida com um sentimento de atualidade acentuada. A transferência é classicamente reconhecida como o terreno em que se dá a problemática de um tratamento psicanalítico, pois é a sua instalação, as suas modalidades, a sua interpretação e a sua resolução que caracterizam este. 